\title{
IMPLEMENTAÇÃO DE SISTEMA INTEGRADO PARA GESTÃO DE CONTRATOS DE OBRAS DE EDIFICAÇÔES EM EMPRESAS DE CONSTRUÇÃO CIVIL
}

Dissertação de Mestrado apresentada à Escola Politécnica da Universidade de São Paulo para obtenção do título de Mestre em Engenharia.

Área de Concentração:

Engenharia de Construção Civil e Urbana

Orientador:

Prof. Dr. Silvio Burrattino Melhado 
Este exemplar foi revisado e alterado em relação à versão original, sob responsabilidade única do autor e com a anuência de seu orientador.

São Paulo, de junho de 2011.

Assinatura do autor

Assinatura do orientador

FICHA CATALOGRÁFICA

Pessarello, Regiane Grigoli

Implementação de sistema integrado para gestão de contratos de obras de edificações em empresas de construção civil I R.G. Pessarello. -- ed.rev. -- São Paulo, 2011.

$218 \mathrm{p}$.

Dissertação (Mestrado) - Escola Politécnica da Universidade de São Paulo. Departamento de Engenharia de Construção Civil.

1.Contratos (Projeto;Sistemas;Administração) 2.Sistema Integrado de gestão 3.Construção civil I.Universidade de São Paulo. Escola Politécnica. Departamento de Engenharia de Construção Civil Il.t. 
À Neide e Ambrósio, meus queridos pais e primeiros mestres;

À irmã Daniele pela silenciosa torcida;

Ao amado Afonso, que há 10 anos me acompanha com dedicação e compreensão;

E à querida Maria Izabella que, a cada dia que passa, é mais essencial em minha vida, tornando-se a razão de todo o meu esforço. 
Um dia, eu acolhi em meu coração, o seguinte:

"não deixe que somente o entusiasmo seja o motivo de seu trabalho. Cultive o amor pelo que faz, pois o entusiasmo é da mente e o amor é do coração, do sentimento. $O$ que é da mente é passageiro, mas o amor é eterno. Procure envolver com amor tudo aquilo que fizer com entusiasmo e terá sucesso".

Agradeço a DEUS, por permitir que eu ame cada dia mais aquilo que faço e possa aproveitar a minha passagem neste plano. Agradeço também por ter colocado, em meu caminho, grandes orientadores.

De alguns orientadores, infelizmente, perdi o contato, outros continuam presentes, e ainda existem aqueles muito especiais, que já não se encontram mais neste plano, agradeço a todos de coração.

Ao professor e engenheiro Eugênio Salvador Giamusso, que foi meu primeiro incentivador na engenharia civil e que nunca mais esquecerei.

Ao meu querido mestre Ubiraci Espinelli Lemes de Souza, que se dedica com amor à engenharia.

E ao professor e grande orientador Silvio Melhado que, com simplicidade e grande sabedoria, ajudou-me a trilhar este caminho com sucesso. 
"A maioria das pessoas não planeja fracassar, fracassa por não planejar."

John L. Beckley

(1757 - 1807) 
Este trabalho busca entender o processo de implementação de sistema integrado para gestão de contratos de obras de edificações em empresas de construção civil e tem como objetivo apresentar os motivos para a implementação, bem como a aplicação das práticas de gestão no mesmo, tomando-se como base o EBS - Ebusiness suite, que representa essa classe de sistemas.

Tendo em vista que os sistemas integrados possuem conceitos de gestão de projetos embutidos, também são definidas e diagnosticadas as práticas para gestão de contratos e apresentados os níveis de gestão e os principais macroprocessos de empresas construtoras, já que o sistema integrado deverá permear entre eles.

Para a elaboração do trabalho foram realizadas revisão bibliográfica, entrevistas com profissionais da área de planejamento e controle e da área de implementação de sistemas, estudos empíricos e exploratórios acerca do processo de implementação de sistemas, além de três estudos de caso em empresas construtoras que fizeram a implementação do sistema (EBS) recentemente.

Como resultado principal deste estudo são identificados os aspectos do processo de implementação, a estratégia das construtoras e os critérios estabelecidos, sendo propostas diretrizes que poderão contribuir para a implementação de sistemas de gestão em outras empresas construtoras.

Palavras-chave: Sistema de gestão. Planejamento e controle. Gestão de Projetos. Sistema integrado. Gestão de contratos. 
The present work seeks to understand the process of implementation of integrated system for building contracts management in construction companies and intends to show the motivations to implement an integrated system and the application of management practices as well taking as basis EBS - E-Business Suite, representing the system class.

Considering those integrated system have embedded management of projects concepts, the practices for contracts management are identified and the levels of management presented along with the key macro processes of construction companies since the integrated system should infuse among them.

To elaborate this work literature review, interviews with professionals in planning and control area and implementation system, empirical and exploratory studies of the process of system implementation are performed, plus three case studies in construction companies that recently decided to implement the system (EBS).

As result of this work aspects of the implementation process, the strategy and criteria established by the construction companies are identified, proposing guidelines that could contribute to the implementation of management system in other construction companies.

Key-words: Management System; Planning and Control; Project Management; Integrated System; Contract Management 


\section{LISTA DE ILUSTRAÇÕES}

Figura 1 - Método de pesquisa

Figura 2 - Adaptação do ciclo PDCA (DEMING, 1950)

Figura 3 - Adaptação dos níveis hierárquicos no gerenciamento da construção (Fonte:

HALPIN, 1992)

Figura 4 - Níveis de informação

Figura 5 - Fases da implementação (Adaptação TURBAN, 2002)

Figura 6 - Exemplo de Controle Físico e Financeiro

Figura 7 - Exemplo de EAP com ramais decompostos até o nível de pacotes de trabalho

Figura 8 - Exemplo de atividades ligadas pelo método do diagrama de precedência 72

Figura 9 - Exemplo de gráfico de Gantt 76

Figura 10 - Etapas do orçamento (SILVA, 1999) 79

Figura 11 - Conceituação de custos planejados, comprometidos e incorrido 84

Figura 12 - Adaptação das composições unitárias da etapa de fundações, exemplificando cálculo das durações, Hh e custo total

Figura 13 - Exemplo de COTA - Custo Orçado do Trabalho Agendado 106

Figura 14 - Módulos do sistema EBS (Fonte: ORACLE, 2010) 126

Figura 15 - Tela inicial - níveis de acesso (fonte: ORACLE, 2010) 128

Figura 16 - Tela Plano de Trabalho - Organização das tarefas conforme EAP 129

Figura 17 - Tela Plano de Trabalho - Organização das tarefas conforme EAR 130

Figura 18 - Tela Plano de Trabalho - Cronograma do projeto 131

Figura 19 - Tela Financeira - Orçamento de custo do projeto 132

Figura 20 - Tela Financeira - Orçamento de receita do projeto 133

Figura 21 - Tela Financeira - Distribuição do custo e receita do projeto ao longo dos meses

Figura 22 - Tela Financeira - Gráfico da curva de distribuição do custo ao longo dos meses

Figura 23 - Tela Plano de Trabalho - Avanço físico do projeto 136

Figura 24 - Tela Geração de Relatórios - Indicadores de desempenho do projeto 137

Figura 25 - Tela Plano de Trabalho - Organização das versões publicadas 138

Figura 26- Processo para fazer uma pesquisa de estudo de caso 142

Figura 27 - Exemplo de cronograma faseado 147

Figura 28 - Cronograma de implementação do sistema - Empresa A 150

Figura 29 - Organograma da equipe de implementação do sistema - Empresa A 152

Figura 30 - Cronograma de implementação do sistema - Empresa B 163

Figura 31 - Organograma da equipe de implementação do sistema - Empresa B 164

Figura 32 - Cronograma de implementação do sistema - Empresa C 175

Figura 33 - Organograma da equipe de implementação do sistema - Empresa C $\quad 175$ 
Fórmula 1 - Percentual concluído por horas (AKKARI, 2003) 89

Fórmula 2 - Percentual de avanço físico por quantidade

Fórmula 3 - Fórmula do IDC - Índice de desempenho de custo

Fórmula 4 - Fórmula do IDP - Índice de desempenho de agendamento

Fórmula 5 - Fórmula do IDAC - Índice de desempenho a concluir 
Gráfico 1 - Distribuições do custo baseado na curva de Gauss e pela programação final 85

Gráfico 2 - Exemplo de distribuição sino baseada no cálculo do MS-Project (2007)

Gráfico 3 - Exemplo de distribuição uniforme baseada no cálculo do MS-Project (2007)

Gráfico 4 - Exemplo de distribuição linear - "Earned value"

Gráfico 5 - Valor Agregado, valor planejado e custos reais 
Quadro 1 - Principais unidades organizacionais das empresas estudadas

Quadro 2 - Áreas mais identificadas na pesquisa de Vivancos e Cardoso (1999)

Quadro 3 - Envolvimento das áreas de empresas construtoras no processo de gestão de contratos (proposição da autora)

Quadro 4 - Macroprocessos típicos das empresas construtoras

Quadro 5 - Roteiro do planejamento (ALMEIDA, 2006)

Quadro 6 - Exemplo de detalhamento da EAP das etapas de fundações e estrutura

Quadro 7 - Classificação dos recursos conforme TCPO (2008)

Quadro 8 - Categorias de recursos (ALMEIDA, 2006)

Quadro 9 - Tipos de vínculo entre tarefas (Adaptação de BERNARDES, 2010)

Quadro 10- Relação das providências a serem tomadas com base no cronograma (MATTOS,

2010)

Quadro 11 - Exemplo de distribuição sino baseada no cálculo do MS-Project (2007)

Quadro 12 - Exemplo de distribuição uniforme baseada no cálculo do MS Project (2007) 86

Quadro 13 - Critérios de medição

Quadro 14 - Exemplo de cálculo de valor agregado

Quadro 15 - Nomenclaturas utilizadas para os valores chaves do valor agregado - 103

Quadro 16 - Exemplo de cálculo do COTR

Quadro 17 - Nomenclaturas utilizadas para os indicadores de performance do projeto 107

Quadro 18 - Sistemas para construção (Fonte: LOTURCO, 2004) 116

Quadro 19 - Carga horária dos treinamentos - Empresa A

Quadro 20 - Cargos e Responsabilidades da equipe de implementação - Fase 2 - Empresa A

Quadro 21 - Carga horária dos treinamentos - Empresa B 162

Quadro 22 - Carga horária dos treinamentos - Empresa C 174

Quadro 23 - Comparativo entre as estratégias de implementação das empresas $\quad 182$

Quadro 24 - Comparativo entre os cronogramas de implementação das empresas $\quad 183$

Quadro 25 - Comparativo entre as funções e responsabilidades dos profissionais envolvidos

Quadro 26 - Comparativo entre os critérios estabelecidos na implementação dos dados 184 Quadro 27 - Riscos e ações mitigadoras na implementação da ferramenta (proposição da autora)

Quadro 28 - Vantagens e desvantagens de algumas práticas de implementação 189

Quadro 29 - Cumprimento dos objetivos específicos do trabalho 
Tabela 1 - Exemplo de levantamento de quantidades

Tabela 2 - Exemplo de composição unitária (TCPO, 2008)

Tabela 3 - Exemplo de custo por etapa do projeto

Tabela 4 - Ponderação do Projeto (ASSUMPÇÃO E ROCHA, 1996)

Tabela 5 - Exemplo de cálculo da representatividade pela duração

Tabela 6 - Exemplo de cálculo da representatividade pelo $\mathrm{Hh}$

Tabela 7 - Exemplo de cálculo da representatividade pelo Custo

Tabela 8 - Exemplo de diferença entre representatividades da tarefa fôrma

Tabela 9 - Exemplo de cálculo do avanço físico utilizando a ponderação pela duração

Tabela 10 - Exemplo de cálculo do avanço físico utilizando a ponderação pelo $\mathrm{Hh}$

Tabela 11 - Exemplo de cálculo do avanço físico utilizando a ponderação pelo custo 


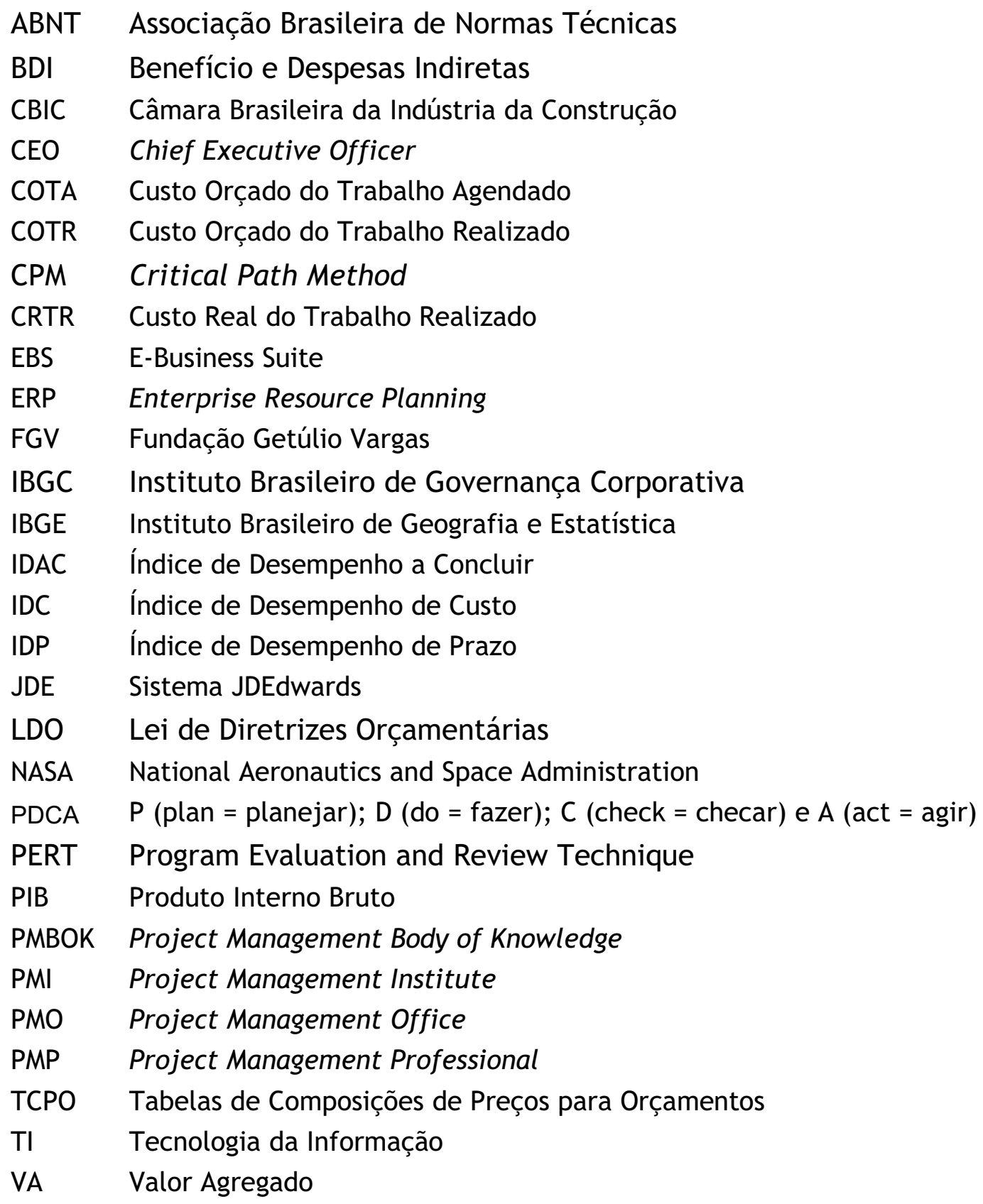


1. Introdução 18

1.1. Considerações iniciais 19

1.2. Justificativa 20

1.3. Objetivo 24

1.4. Metodologia 24

1.4.1. Revisão bibliográfica 25

1.4.2. Entrevistas 26

1.4.3. Pesquisa das ferramentas 27

1.4.4. Estudos de caso 28

1.4.5. Análise dos resultados 29

1.4.6. Resultado final 29

1.5. Estruturação do trabalho 30

2. Estudo dos níveis de gestão e principais macroprocessos 33

2.1. Gestão de contratos 34

2.1.1. Níveis de gestão de contratos 36

2.1.2. Interposição das informações nos níveis gerenciais 40

2.1.3. Influência dos níveis gerenciais na implementação de ferramentas de gestão 41

2.2. Principais macroprocessos 44

2.2.1. Áreas de apoio ao processo de gestão de contratos 47

2.2.2. Área de execução do contrato 52

2.2.3. Áreas de planejamento e controle dos contratos 55

3. Definição e diagnóstico das práticas de gestão de contratos 61

3.1. Práticas de gestão de contratos 62

3.2. Planejamento do projeto 63

3.2.1. Planejamento físico 65

3.2.2. Planejamento econômico-financeiro 77

3.3. Controle do projeto 88

3.3.1. Controle físico 88

3.3.2. Controle financeiro 100

3.3.3. Desempenho geral do projeto 101

4. Implementação de sistema integrado para gestão de contratos 111 
4.1. Implementação de sistemas em empresas construtoras 111

4.2. Motivos para implementação de ferramenta de gestão 116

4.2.1. Governança corporativa ___ 116

4.2.2. Disciplina _ 117

4.2.3. Organização__ 118

4.2.4. Padronização___ 118

4.2.5. Rastreabilidade___ 119

4.3. Levantamento das necessidades das empresas ___ 120

4.4. Processo de escolha do sistema de gestão __ 121

4.4.1. Avaliação das ferramentas disponíveis no mercado ___ 121

4.4.2. Contratação e planejamento para implementação da ferramenta __ _ 122

4.4.3. Implementação da ferramenta escolhida___ 123

4.5. Ferramentas disponíveis no mercado__ 124

4.5.1. Caracterização do EBS - E-Business Suite __ 125

4.5.2. Aplicação das práticas de gestão de contratos no EBS ___ 127

5. Estudos de caso_ 140

5.1. Metodologia utilizada para estudos de caso ___ 141

5.2. Estudo de Caso $1 \ldots 144$

5.2.1. Caracterização da construtora A _ 144

5.2.2. Estratégia de implementação __ 145

5.2.3. Cronograma de implementação ___ 150

5.2.4. Funções e responsabilidades dos profissionais envolvidos __ 151

5.2.6. Critérios estabelecidos com relação à utilização do sistema ___ 153

5.2.7. Dificuldades enfrentadas __ 157

5.2.8. Resultados observados após a implementação___ 158

5.3. Estudo de caso 2

5.3.1. Caracterização da construtora B 159

5.3.2. Estratégia de implementação __ 160

5.3.3. Cronograma de implementação __ 162

5.3.4. Funções e responsabilidades dos profissionais envolvidos _ 163

5.3.5. Critérios estabelecidos com relação à utilização do sistema __ 165

5.3.6. Dificuldades enfrentadas __ 169

5.3.7. Resultados observados após a implementação___ 171

5.4. Estudo de caso 3 172

5.4.1. Caracterização da construtora $C$

5.4.2. Estratégia de implementação __ 172

5.4.3. Cronograma de implementação __ 174 
5.4.4. Funções e responsabilidades dos profissionais envolvidos 175

5.4.5. Critérios estabelecidos com relação à utilização do sistema 176

5.4.6. Dificuldades enfrentadas 179

5.4.7. Resultados observados após a implementação 180

5.5. Análise dos Estudos de Caso 181

5.5.1. Principais riscos na implementação do sistema 184

5.6. Limitações da ferramenta na gestão de contratos de obras 186

5.1. Considerações acerca dos Estudos de casos 188

6. Considerações finais 191

6.1. Cumprimento dos objetivos 191

6.2. Dificuldades e limitações do trabalho 193

6.3. Benefícios observados com o sistema de gestão de contratos 193

6.4. Diretrizes para futuras implementações da ferramenta 194

6.5. Perspectivas de continuidade do estudo do tema ou aspectos correlatos 196 REFERÊNCIAS BIBLIOGRÁFICAS 197

REFERÊNCIAS CONSULTADAS 207 
“Primeiramente, precisamos entender que gestão é uma função delegada, que deve ser exercida pelos administradores com o máximo rigor, zelo e probidade".

Krieck (2003)

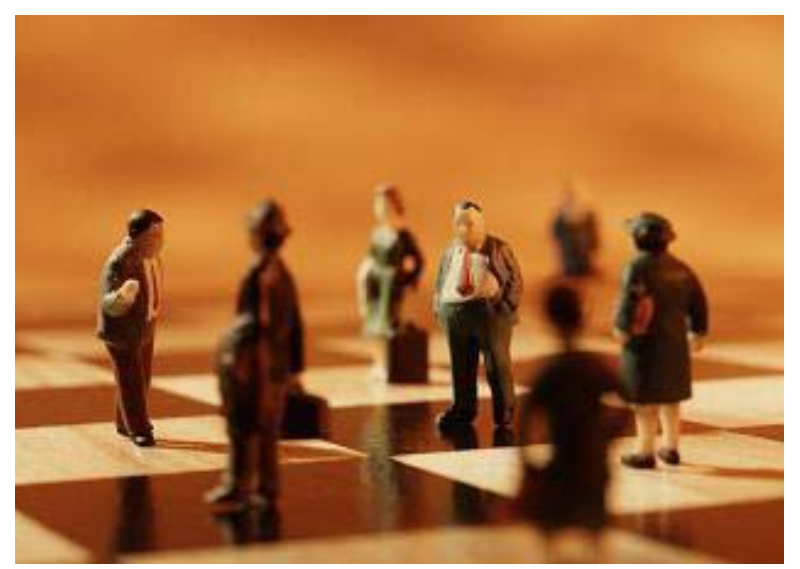




\section{Introdução}

Este trabalho partiu da idéia de que o Brasil passa por um processo de crescimento da economia, que reflete principalmente no setor da construção civil, aumentando a demanda para as empresas que atuam nesse segmento. Porém, verifica-se que empresas construtoras não possuem domínio dos elementos essenciais para gestão de seus $\operatorname{contratos}^{1}$ de obras. Dentre esses elementos, pode-se citar:

- falta de informações rápidas sobre o projeto ${ }^{2}$ em todos os níveis de gestão;

- falta de metodologia e indicadores para análise das informações do projeto;

- falta de padronização, organização e credibilidade das informações geradas, dentre outros.

O pouco domínio desses elementos pode implicar o desempenho ruim do contrato, no que diz respeito ao cumprimento dos prazos, custos e escopo, causando insatisfação aos envolvidos no projeto, acionistas e principalmente ao cliente.

Com base nisso, fica evidente a necessidade de implementação de ferramentas apropriadas para a gestão de contratos em empresas de construção civil. Para fundamentar a relevância deste trabalho, serão apresentadas, nesta introdução, as justificativas para o estudo do tema, baseadas em considerações iniciais relativas ao contexto atual da construção civil e na experiência de estudiosos

\footnotetext{
${ }^{1}$ Neste trabalho, entende-se como "Gestão de Contratos" a gestão das obras/projetos e não a gestão do documento como instrumento legal.

2 De acordo com o PMBOK (2008), um projeto (português) ou project (inglês americano) é um esforço temporário empreendido para criar um produto, serviço ou resultado exclusivo. Neste trabalho, caracteriza-se como projeto, o processo de execução de determinado empreendimento (obra), desde a fase de planejamento até a entrega final.
} 
sobre o assunto. Na sequência, serão apresentados os objetivos e a metodologia a ser utilizada e, por fim, a organização dos assuntos nos capítulos.

\subsection{Considerações iniciais}

Embora a crise mundial ${ }^{3}$ tenha desencadeado a recessão em vários países, no Brasil, os impactos foram menores. Conforme Attuch (2008), o governo brasileiro colocou em marcha o maior pacote de obras públicas da sua história, com o objetivo de garantir a continuidade do crescimento da economia, além de abrir fronteiras de desenvolvimento em todas as regiões do país. Com isso, a taxa de investimentos públicos e privados de 2010 foi a $2^{\mathrm{a}}$ maior da década, de acordo com o IBGE- Instituto Brasileiro de Geografia e Estatística.

Para garantir que a burocracia não atrapalhe os investimentos em obras públicas, o Congresso Nacional aprovou, no dia 8 de julho, a LDO (Lei de Diretrizes Orçamentárias) de 2011, que prevê a flexibilização das exigências para contratação de obras da Copa do Mundo de 2014 e Olimpíada de 2016. Entre as alterações, estão a redução dos critérios para licença ambiental, desapropriação de imóveis e a possibilidade de se contratar empresas em regime emergencial, sem o cumprimento da Lei de Licitações nº 8.666 (ROCHA, 2010).

Essas ações beneficiarão diversos projetos que não se restringem a estádios e ginásios de esportes, mas fazem com que o Brasil torne-se um verdadeiro canteiro de obras, já que os investimentos ocorrerão em 12 cidades brasileiras, injetando mais de 140 bilhões de reais na economia brasileira (ROCHA, 2010).

\footnotetext{
${ }^{3}$ Segundo Silber (2010), a crise mundial de 2008 teve como grande pano de fundo a gradual desregulamentação do mercado financeiro iniciada nos Estados Unidos, na Europa e no Japão a partir de 1980. Krugman (2010) ainda destaca, que a crise foi evidenciada a partir da crise no mercado imobiliário norte-americano em 2008, causando grande recessão em diversos países.
} 
As 12 cidades-sede da copa do mundo receberão investimentos de infraestrutura da ordem de $\mathrm{R} \$ 14,54$ bilhões, com obras rodoviárias, de saneamento, manutenção e ampliação de aeroportos, dentre outros (ROCHA, 2010).

Mas esses investimentos não ocorrerão apenas na área pública, terão reflexos consideráveis também na área privada, como: rede hoteleira, shoppings, lojas, hospitais, enfim, toda a infraestrutura necessária que envolve esses tipos de eventos internacionais.

Segundo Ernst \& Young e FGV (2010), o ponto de partida para enfrentar os desafios que estão por vir é o estabelecimento adequado do processo de planejamento, governança e gestão dos projetos, com o objetivo de cumprir prazo, custo previsto e qualidade exigida.

\subsection{Justificativa}

O setor da construção civil vive um momento de aquecimento, isto é, de crescimento da demanda, o que favorece o acirramento da concorrência, o encurtamento dos prazos e o encarecimento da mão-de-obra. Para que as empresas desse segmento tenham sucesso, o uso de ferramentas e políticas de gestão, alinhadas com um eficiente planejamento estratégico, pode ser de grande valia.

Assim, conforme Medeiros (2008), o planejamento ganha importância e "visa garantir obras produtivas, com qualidade e principalmente o cumprimento dos prazos, podendo ser a diferença entre o crescimento ou o declínio de uma empresa". 
Além da importância do planejamento, Mattos (2010) ressalta que:

As empresas se deram conta de que investir em gestão e controle de processos é inevitável, pois sem essa sistemática gerencial os empreendimentos perdem de vista seus principais indicadores: o prazo, o custo, o retorno do investimento e o fluxo de caixa. Informação rápida é um insumo que vale ouro. (MATTOS, 2010, p. 21)

Com isso, torna-se necessário buscar formas de melhorar a efetividade no gerenciamento das informações relacionadas ao planejamento e controle de empreendimentos de construção civil. Entre essas formas, está o uso de ferramentas da tecnologia da informação (ZEN, 2006).

Também, para contribuir com o planejamento e gestão de contratos, gerando informações da situação da obra em relação ao programa que foi traçado, quais os desvios em relação ao previsto e onde eles estão, há sistemas integrados que têm como objetivo organizar as informações, nos diversos níveis de gestão, além de garantir informações centralizadas que permitam a rápida tomada de decisão (REHM, 2003).

De acordo com Rehm, Gerente de $\mathrm{TI}^{4}$ da Odebrecht (2003):

A ferramenta de gestão tem de responder de forma bastante simples, rápida e eficiente. Sem ferramenta, você pode obter essas respostas, porém, pode demorar tanto que o cenário já mudou e, provavelmente, estaremos fazendo 'autópsia' do porquê desviamos tanto do planejado.(REHM, 2003, p.13-18)

Assolari (2005) e Baltazar et al. (2008) também ressaltam que, para que as empresas sejam competitivas, é inevitável que elas caminhem, cada vez mais, para ambientes de sistemas integrados e salientam a importância da centralização das informações de forma integrada.

De acordo com Saccol et al. (2004), os sistemas integrados de gestão são uma das tecnologias mais utilizadas e discutidas na área de sistemas de informação. Dessa

\footnotetext{
${ }^{4}$ Tecnologia da Informação: conjunto de diversos sistemas de informação, usuários e gestão de uma empresa (TURBAN, 2002).
} 
forma, os sistemas integrados não podem mais ser encarados como um diferencial competitivo, e sim como uma ferramenta "essencial competitiva” (RODRIGUES et al., 2008).

Portanto, a decisão de implementação de um sistema integrado para gestão de contratos que proporcione uma maior visibilidade do projeto, no que diz respeito ao acompanhamento dos prazos, custos e escopo, não deve estar fundamentada apenas em uma questão de tecnologia, mas também na estratégia da empresa.

Entretanto, Laufer (1987) ressalta que, frequentemente há falhas na implementação de sistemas para área de planejamento, adquiridos e inseridos em um ambiente organizacional, sem antes haver a identificação das necessidades de informações de seus usuários.

Coelho (2009) relaciona alguns problemas ocorridos, mesmo em empresas que possuam sistema de gestão, dentre eles:

- falta de difusão das informações, sendo que, muitas vezes, a informação está disponível no sistema, de forma unificada e com acesso fácil para todos os departamentos interessados, mas fica restrita a alguns usuários;

- falta de padronização de alguns processos, formulários e registros;

- incoerência de registros, tomando-se muito tempo em conferências e correções manuais.

Por isso, alguns autores (SEDERA et al., 2003 apud SACCOL et al., 2004) destacam a importância de se avaliar o impacto dos sistemas sobre a efetividade organizacional e recomendam um estudo preliminar do processo de implementação da ferramenta.

Porém, os estudos sobre o assunto, como a dissertação de Valente (2004), que trata da implementação de ERP - Enterprise Resource Planning em pequenas e médias empresas do setor da construção civil, e o estudo de Jesus (2004) estão 
direcionados ao processo de implementação de sistemas integrados, no que diz respeito à área de $\mathrm{TI}$.

Embora a pesquisa de Valente (2004) tenha como estudo de caso uma construtora, o tema é tratado apenas no tocante ao processo de implementação da ferramenta, não abrangendo o conhecimento das práticas de gestão de contratos que estão embutidas nesses sistemas, nem a aplicabilidade das práticas de gestão nos macroprocessos típicos de empresas construtoras. Além disso, o trabalho transcende a simples implementação, quando nos estudos de caso busca mostrar a estratégia de implementação frente aos critérios estabelecidos, apontando as vantagens e desvantagens de algumas decisões tomadas pelas construtoras.

Com base nisso, esta dissertação busca propor diretrizes para o processo de implementação de sistema integrado de gestão de contratos em empresas de construção civil, não apenas sobre o enfoque sistêmico, mas também voltado aos conceitos embutidos no sistema, que são essenciais e devem ser observados pelas empresas construtoras.

Com o seu desenvolvimento, espera-se contribuir para os futuros processos de implementação desse tipo de sistema.

\subsection{Objetivo}

O objetivo geral deste trabalho é contribuir para o conhecimento que envolve o processo de implementação de sistemas integrados para gestão de contratos em empresas de construção civil, propondo diretrizes para futuras implementações da ferramenta.

Os objetivos específicos podem ser expressos como:

- apresentar os níveis de gestão do contrato e os principais macroprocessos típicos das empresas construtoras; 
- definir e diagnosticar as práticas de gestão de contratos de obras de edificações em construção civil;

- apresentar os processos de implementação do sistema, discutindo os motivos da implementação, aplicabilidade da ferramenta frente às necessidades da empresa e a aplicação das práticas de gestão na ferramenta analisada;

- discutir os impactos causados com a implementação do sistema, baseando-se nos estudos de caso e

- identificar as principais limitações da ferramenta analisada na gestão de contratos de obras.

\subsection{Metodologia}

Para se atingir os objetivos propostos, foram adotados métodos qualitativos descritivos, empregando estudos de casos que, segundo Yin (2009), trata-se de uma "investigação empírica que observa um fenômeno contemporâneo em um contexto realístico $[\ldots] "$.

A metodologia será detalhada nos tópicos seguintes conforme a estrutura representada na Figura 1. 


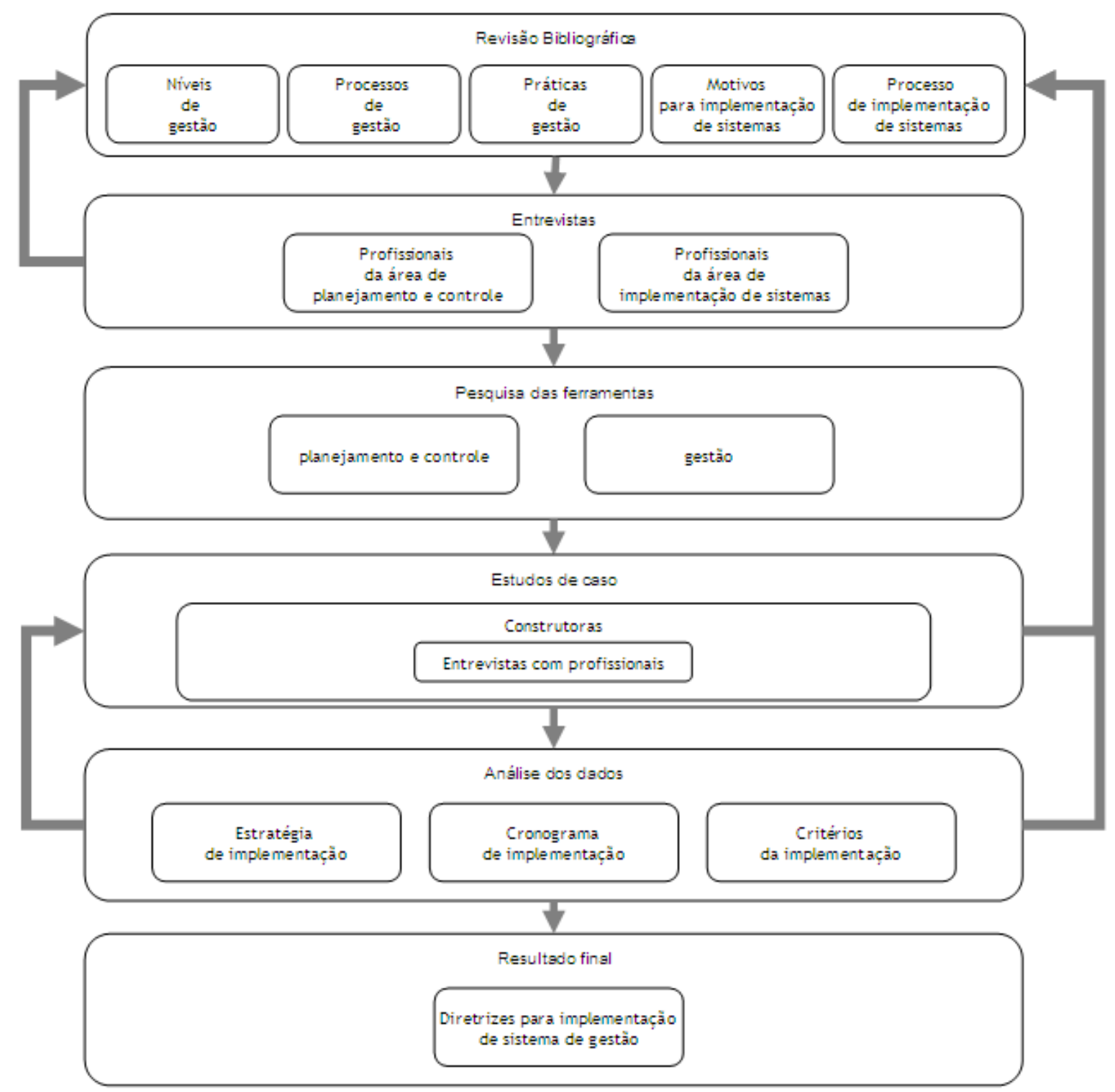

Figura 1 - Método de pesquisa

\subsubsection{Revisão bibliográfica}

A pesquisa bibliográfica abrangeu teses, dissertações e artigos, focando os níveis de gestão dos contratos, nos principais macroprocessos típicos das empresas construtoras, nas práticas de planejamento e gestão de projetos, especificamente, relacionadas às empresas de construção civil, bem como os motivos que levam as construtoras a implementar sistemas de gestão e o processo dessa implementação. 
A fundamentação teórica constituiu uma etapa relevante no conhecimento relativo aos processos típicos das empresas construtoras e também no conhecimento e conceitos quanto às práticas de planejamento e gestão de projetos, elementos essenciais que estão embutidos nos sistemas integrados de gestão.

\subsubsection{Entrevistas}

Com base nos estudos iniciais sobre o tema, foram elaborados questionários que serviram de roteiro para as dez entrevistas ${ }^{5}$ realizadas com profissionais da área de planejamento e controle, com o objetivo principal de identificar as principais demandas na referida área que deveriam ser supridas com a implementação de um sistema de gestão de contratos.

Com isso, também foram observadas as principais práticas e ferramentas de planejamento e controle utilizadas pelos entrevistados, o que possibilitou constatar que os conceitos de planejamento e controle devem estar contidos no sistema de gestão de contratos.

A partir desse ponto, verificou-se a necessidade de levantar dados relativos a implementações de ferramentas em empresas construtoras. Para isso, inicialmente foi elaborado questionário e realizadas entrevistas com dois profissionais $^{6}$ de empresas especializadas na implementação de sistemas de gestão de contratos.

Nas entrevistas, foram identificadas as ferramentas disponíveis no mercado e algumas empresas que estavam em processo de implementação dessas ferramentas.

\footnotetext{
${ }^{5}$ Veja no apêndice deste trabalho os questionários utilizados (apêndice A e apêndice B).

${ }^{6}$ Veja no apêndice deste trabalho os questionários utilizados (apêndice C).
} 


\subsubsection{Pesquisa das ferramentas}

A pesquisa das ferramentas se deu sobre dois enfoques diferentes: um deles sobre às ferramentas de planejamento e controle e outro relativo às ferramentas de gestão, já que são ferramentas que se complementam.

Com relação às ferramentas de planejamento e controle, buscou-se estudar as mais difundidas no mercado, já que possuem conceitos de planejamento e controle embutidos, são largamente utilizadas pelos profissionais da área, conforme entrevistas realizadas com os profissionais de planejamento e controle, e trabalham em conjunto com o sistema de gestão.

Para tal, estudou-se o MS-Project ${ }^{7}$ e o Primavera $^{8}$, sendo analisadas as suas principais funcionalidades, por meio da realização de cursos de aperfeiçoamento, estudo dos manuais técnicos das ferramentas e manuais de treinamentos.

Entretanto, nesta dissertação o foco maior foi dado ao MS-Project, por ser uma ferramenta mais difundida entre os profissionais de planejamento. Akkari (2003) ainda ressalta que o MS-Project é fácil de utilizar, pois trabalha em ambiente Windows, sendo mais conhecido entre os usuários dos computadores de pequeno porte. Além disso, pode ser adquirido facilmente no mercado e, por estar direcionado unicamente para planejamento e controle, possui recursos específicos desse processo.

Posteriormente, iniciou-se um estudo exploratório das ferramentas disponíveis no mercado para gestão de contratos, tomando como base as indicações obtidas nas entrevistas com os profissionais de implementação de sistemas.

\footnotetext{
${ }^{7}$ MS-Project é um software da empresa Microsoft, desenvolvido para planejamento e controle de projetos.

${ }^{8}$ Primavera é um software da empresa Oracle desenvolvido para planejamento e controle de projetos.
} 
De posse das informações, optou-se, por escolher o EBS - E-Business Suite da Oracle e o MS-Project, como referência para os estudos de caso.

O EBS foi selecionado principalmente por se tratar de uma ferramenta que gerencia portfólios de modo sistêmico. Além disso, procurou-se nos estudos de caso, analisar empresas que utilizam-se as mesmas ferramentas, permitindo um comparativo entre os processos de implementação dos sistemas nas empresas estudadas.

\subsubsection{Estudos de caso}

Nesta etapa da pesquisa, buscou-se selecionar empresas construtoras que estivessem em fase de implementação ou já tivessem concluído a implementação do sistema de gestão. Ressaltando que foram selecionadas construtoras que utilizariam ou já utilizavam a mesma ferramenta de gestão 9 .

Com o apoio dos profissionais de empresas implementadoras, foram selecionadas três construtoras que estavam com o processo de implementação em andamento, assegurando-se, durante os contatos, a preservação da identidade dos profissionais e das empresas selecionadas para os estudos de caso.

Na sequência, como os estudos de caso usam como referências as entrevistas com os envolvidos no processo e a análise direta dos fatos (YIN, 2009), foi elaborado um roteiro ${ }^{10}$ contendo as informações principais que seriam questionadas e observadas nas construtoras selecionadas.

Procurou-se, nesse roteiro, ressaltar os fatos relativos à estratégia da empresa na implementação do sistema, a utilização do sistema nos níveis de gestão e sua ocorrência nos principais macroprocessos das empresas, buscando-se verificar a aplicabilidade das práticas de gestão nos processos das construtoras.

\footnotetext{
${ }^{9}$ EBS - E-Business Suite (Oracle).

${ }^{10}$ Veja no apêndice o roteiro utilizado nos estudos de caso (apêndice D).
} 
Por fim, procurou-se relacionar com os estudos de casos as dificuldades enfrentadas pelos envolvidos no processo de implementação e as limitações do sistema para gestão de contratos.

\subsubsection{Análise dos resultados}

Após o levantamento dos dados relativos à implementação do sistema de gestão de contratos nas empresas construtoras, as informações foram organizadas e consolidadas de forma a possibilitar comparação entre os aspectos adotados pelas empresas estudadas.

Esse comparativo foi disposto conforme os assuntos mais relevantes da pesquisa, nos seguintes tópicos:

- estratégia de implementação;

- cronograma de implementação;

- funções e responsabilidades dos profissionais envolvidos;

- critérios estabelecidos na implementação dos dados.

\subsubsection{Resultado final}

Com base nos estudos realizados, buscou-se fazer uma proposição de diretrizes, apontando pontos críticos e relevantes para futuras implementações, de modo a contribuir para o conhecimento que envolve esse tipo de implementação. 


\subsection{Estruturação do trabalho}

O trabalho está estruturado em 6 capítulos principais, relacionados à implementação de sistema integrado de gestão de contratos de obras em empresas de construção civil.

O primeiro deles consiste em uma breve introdução sobre a importância e justificativas para apresentação do tema, baseando-se em considerações iniciais relativas ao contexto atual da construção civil. Nesse primeiro capítulo, ainda são apresentados os objetivos gerais e específicos e a metodologia utilizada para seu cumprimento, além das limitações do trabalho.

No segundo capítulo, são focados os níveis de gestão nos contratos de obras em empresas de construção civil e, em seguida, são descritos os principais macroprocessos de empresas construtoras.

Posteriormente, são apresentadas, no terceiro capítulo, as definições e diagnósticos das práticas de gestão de contratos e a relevância do assunto na implementação de sistema de gestão de contratos. Para um melhor entendimento do tema, preferiu-se separar o capítulo em dois tópicos, um relacionado ao planejamento e outro ao controle. Em ambos os tópicos, ainda há uma subdivisão, separando os assuntos em duas abordagens: a abordagem física e a financeira do projeto. Por fim, são discutidas as práticas para análise do desempenho geral do projeto, por meio da técnica de valor agregado e de indicadores de desempenho do projeto.

Após breve conhecimento das práticas de gestão, macroprocessos das empresas construtoras e níveis de gestão dos contratos, são discutidos, no quarto capítulo, os motivos para a implementação de um sistema de gestão de contratos, aplicação da ferramenta dentro das necessidades das empresas construtoras, bem como a aplicação das práticas de gestão na ferramenta analisada. 
No quinto capítulo, encontra-se o cerne da pesquisa: nele são descritos os dados relativos à implementação de sistema integrado de gestão de contratos em três empresas construtoras. Intitulado estudos de caso, serão observados os aspectos abordados no processo de implementação. Com isso, os dados da pesquisa serão analisados, bem como as metodologias utilizadas, impactos causados e as limitações da ferramenta, de modo a contribuir para o conhecimento que envolve esse tipo de implementação.

Como resultado obtido com o trabalho, o sexto capítulo traz diretrizes para futuras implementações da ferramenta em empresas construtoras, favorecendo o aprimoramento do processo de implementação. Finalizando o capítulo, serão analisados o cumprimento dos objetivos iniciais frente aos resultados e às dificuldades e limitações do trabalho, além de serem tecidas sugestões para pesquisas posteriores sobre $o$ assunto. 
"A única coisa do planejamento é que as coisas nunca ocorrem como foram planejadas."

Lúcio Costa

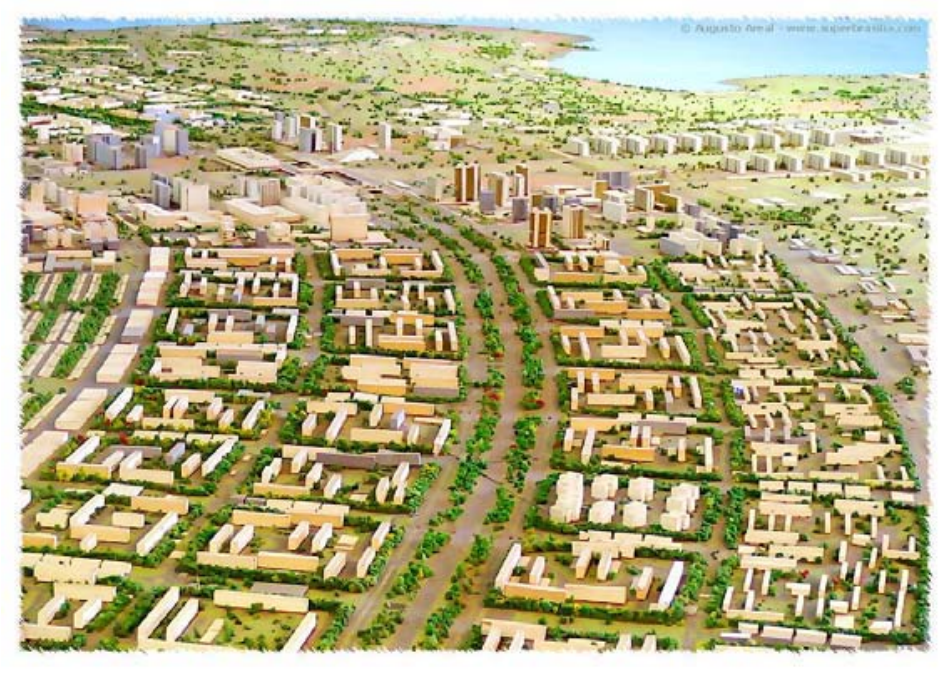




\section{Estudo dos níveis de gestão e principais macroprocessos}

Este capítulo, primeiramente, fará uma abordagem dos níveis de gestão das empresas construtoras. Para isso, são apresentadas definições de estudiosos que caracterizam os níveis hierárquicos de acordo com as funções exercidas. Tais níveis vão desde as áreas operacionais das obras, até as áreas estratégicas da empresa, como diretorias e gerências.

A partir da análise introdutória, são discutidas as informações relativas aos projetos, que permearão os níveis de gestão e a influências dos mesmos níveis na implementação do sistema.

Além disso, como o sistema de gestão de contratos deverá permear nos vários níveis de gestão e por vários processos, seja gerando informações para andamento do processo, seja recebendo informações, faz-se necessário um estudo com relação aos principais macroprocessos típicos de empresas construtoras.

Para a discussão dos macroprocessos, recorreu-se inicialmente a pesquisas realizadas por especialistas em estruturas organizacionais de empresas construtoras. Na sequência, com base em entrevistas ${ }^{11}$ e estudos empíricos os processos que estão relacionados ao sistema de gestão, identifica-se as áreas de apoio ao processo de gestão de contratos, áreas relacionadas à execução do contrato $^{12}$ e áreas que realizam o acompanhamento e controle dos contratos, sendo apresentadas as suas principais atividades. Cabe salientar que o objetivo do trabalho não é caracterizar todas as atividades ocorridas nas áreas citadas, mas apresentar as que têm relação com o sistema integrado para gestão de contratos.

\footnotetext{
${ }^{11}$ Entrevistas com profissionais da área de implementação de sistemas.

${ }^{12}$ Entende-se também como áreas relacionadas à execução do projeto.
} 


\subsection{Gestão de contratos}

As primeiras técnicas de gestão tiveram início no século XX, em que Taylor (1916) formou um dos primeiros conceitos de gerenciamento moderno, com estudos sobre a indústria metalúrgica americana. Em seus estudos, Taylor conceitua que o trabalho pode ser analisado e melhorado se dividido e focado em suas partes elementares (OLIVEIRA, 2003).

Após a $2^{\mathrm{a}}$ Guerra Mundial, período marcado por projetos de grande complexidade e prazos de implementação cada vez menores, iniciou-se uma fase de grande demanda por ferramentas de gestão. Entretanto, segundo Oliveira (2003), no Brasil, há poucas décadas, quem se utilizava de cronogramas detalhados como base de trabalho poderia ser considerado um gestor "sofisticado".

Conceitualmente, o termo "gestão" evoluiu com a origem do termo "gestão da qualidade", na década de 90, e caracteriza-se como o conjunto de ações de planejamento, organização das competências, responsabilidade e autoridades, comunicação, controle, tomada de decisão e melhoria (SOUTO, 2006).

Já, Mattos (2010) enfatiza que as técnicas de gestão passaram a nortear o gerenciamento de contratos de obras no final da década de 80 , destacando que a boa gestão prescinde de um bom planejamento e toma como base o Ciclo PDCA ${ }^{13}$.

Especificamente no que diz respeito à gestão de contratos de obras ${ }^{14}$, vale a pena definir que o contrato é o registro formal das vontades expressas por duas ou mais partes, com a finalidade de regular uma atividade, como a execução de uma construção (LIMMER, 1997). E, em virtude da grande quantidade de variáveis envolvidas na gestão de contratos de obras, como mão-de-obra, suprimentos,

\footnotetext{
${ }^{13}$ PDCA onde: $\mathrm{P}$ (plan = planejar); $\mathrm{D}($ do = fazer); C (check = checar) e A (act = agir). Desenvolvido originalmente por Walter Shewart, em 1920, ganhou notoriedade apenas em 1950, com Edwards Deming, autor famoso pelos princípios de Gerenciamento da Qualidade Total.

${ }^{14}$ Neste trabalho, entende-se como "Gestão de Contratos" a gestão das obras e não a gestão do documento "contrato" como instrumento legal.
} 
intempéries, interferências, retrabalho e perdas periódicas de produtividade, Mattos (2010) ressalta que o Ciclo PDCA encaixa-se perfeitamente nos processos da construção civil, enfatizando a relação entre o planejamento, controle e as ações preventivas e corretivas cabíveis. Com isso, conclui-se que essa seria a metodologia adequada para a gestão de contratos de obras de construção civil.

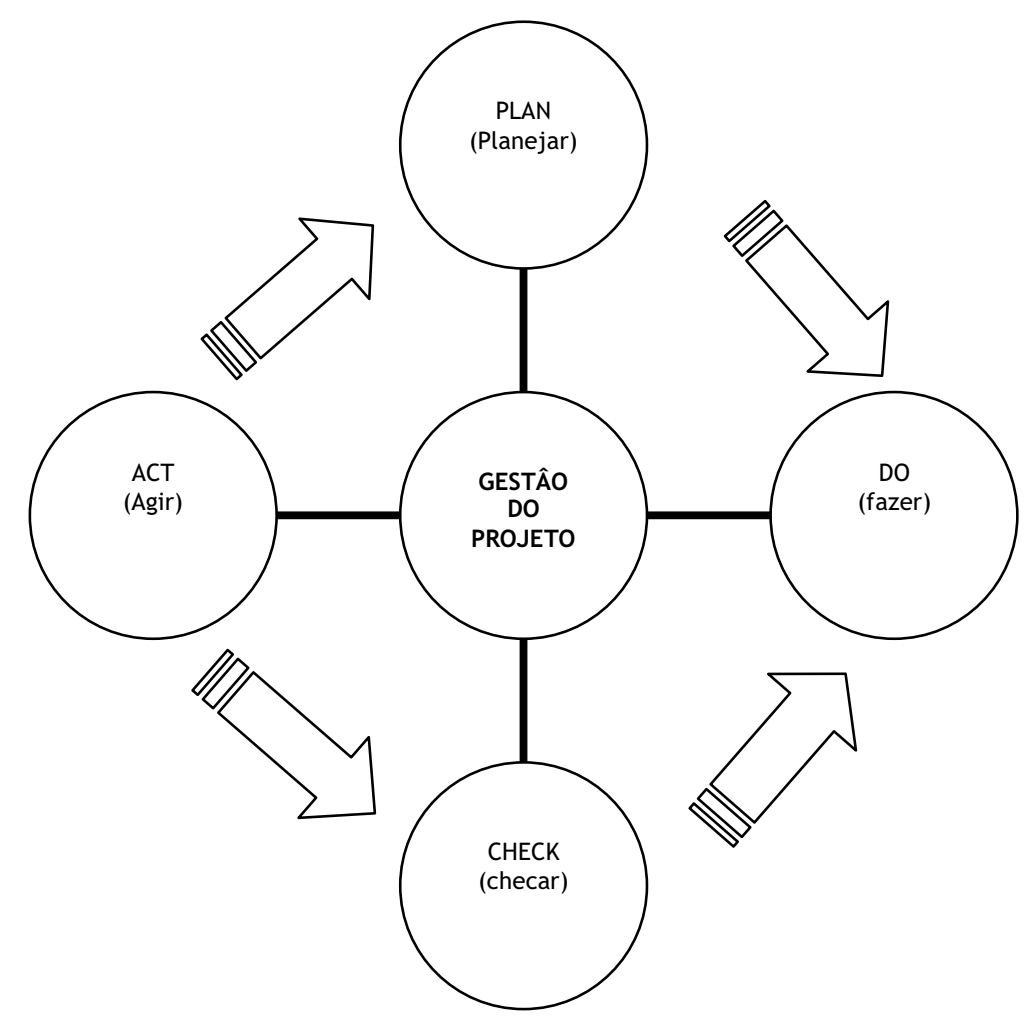

Figura 2 - Adaptação do ciclo PDCA (DEMING, 1950)

Pode-se dizer, então, que o processo sucessivo de planejamento, execução, controle e as ações de melhoria garantem o processo de gestão do contrato, podendo-se adaptar o desenho tradicional do ciclo PDCA, com o termo "Gestão do Projeto" no centro, dependendo do equilíbrio dos demais elementos, conforme Figura 2. 


\subsubsection{Níveis de gestão de contratos}

A gestão é um processo pelo qual os objetivos das empresas são alcançados por meio do uso de recursos (pessoas, dinheiro, energia, materiais, espaço, tempo). Esses recursos são considerados insumos e alcançar objetivos é o resultado do processo (TURBAN, 2002).

Krieck (2003) também ressalta que, primeiramente, precisa-se entender que gestão é uma função delegada, ou seja, passada mediante autorização para que outrem a faça. E essa função deve ser exercida pelos administradores com o máximo rigor, zelo e probidade. Isso dá a idéia de que a gestão é passada de um nível a outro, sendo delegada conforme os níveis hierárquicos e funções exercidas pelos gestores.

Halpin et al. (1992) caracterizam os níveis hierárquicos de acordo com as funções básicas exercidas, dividindo-os, basicamente, em dois focos principais: um, relacionado aos atributos do projeto e na composição física dos elementos e, outro, nas áreas de ação e processos tecnológicos, conforme apresentado na Figura 3. 


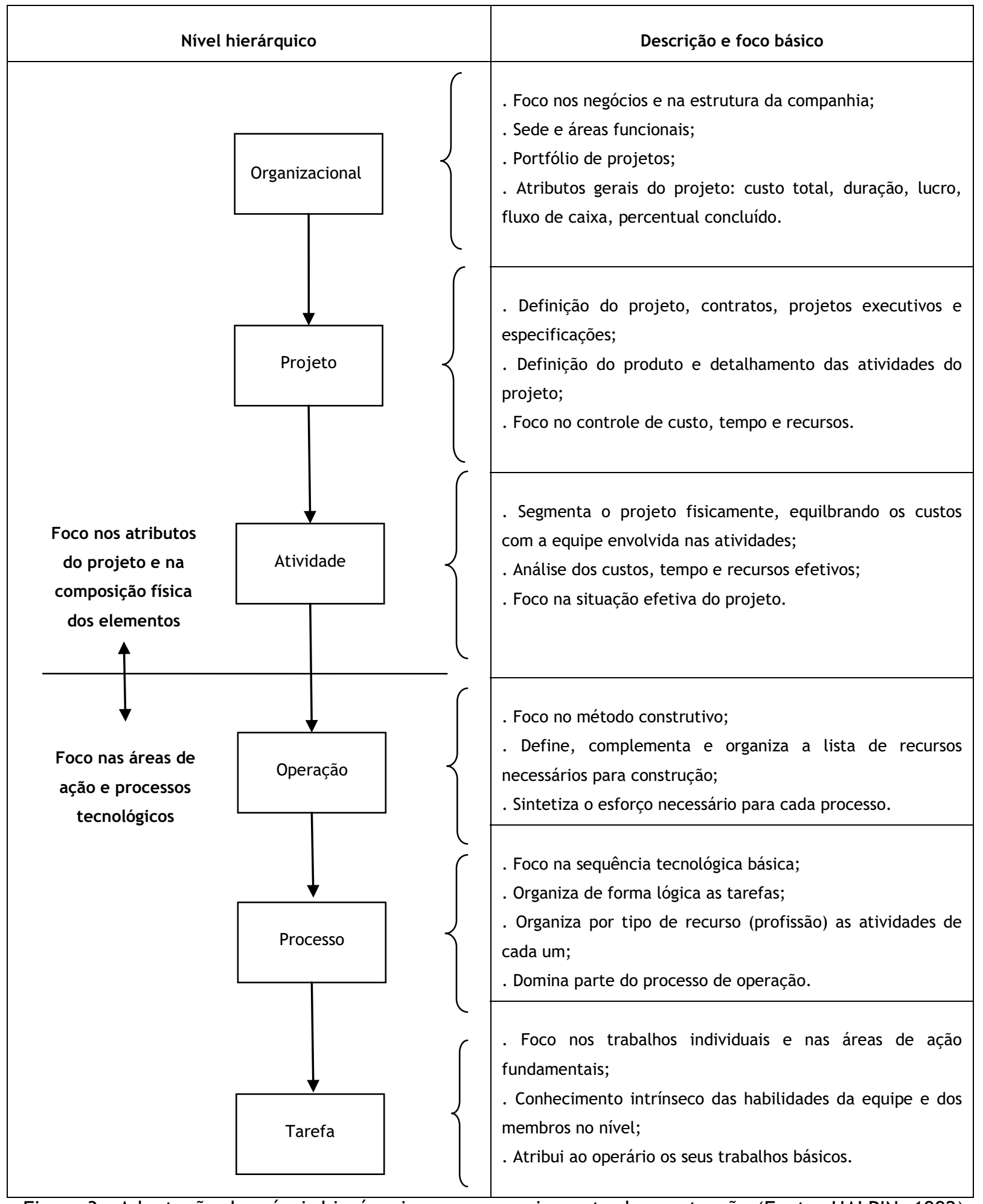

Figura 3 - Adaptação dos níveis hierárquicos no gerenciamento da construção (Fonte: HALPIN, 1992) 
Já Laufer (2009) identifica três níveis gerenciais relacionados às funções dos profissionais, são eles:

- nível estratégico: diretores

- nível tático: engenheiros de produção

- nível operacional: mestres de obra e subempreiteiros

Porém, do ponto de vista da gestão de contrato, as funções são mais abrangentes e podem ser representadas da seguinte forma:

- Nível estratégico: acionistas, diretoria e comitês

- Nível tático: gestor da obra, engenheiros de produção, planejamento e controle

- Nível operacional: mestres de obra e subempreiteiros, administrativos de obras e auxiliares técnicos

Da mesma forma, pode-se entender que a tomada de decisões também se divide nos mesmos três níveis, conforme Assumpção (1996).

- Nível estratégico: está relacionado à alta gerência, sendo bastante agregado e servindo de diretriz para os demais níveis (ASSUMPÇÃO, 1996).

As decisões tomadas nesse nível hierárquico estão relacionadas às seguintes definições:

- Participação ou não da empresa na concorrência, seja pública ou privada;

- Aprovação da margem do contrato e seus respectivos valores de custo e receita, além do desembolso/investimento estimado;

- Seleção da equipe de coordenação (nível tático). 
- Nível tático: são tomadas decisões no sentido de equacionar os meios e procedimentos que serão utilizados para executar a obra (ASSUMPÇÃO, 1996).

Oliveira (2000) detalha que, nesse nível, as decisões envolvem definições sobre os seguintes assuntos:

- Datas de início e conclusão das principais fases da obra;

- Plano de ataque à obra, com definição das sequências e sentidos de execução (trajetória) ao longo dos pavimentos;

- Estratégia de utilização das equipes de produção (número e tamanho de equipes);

- Estratégia para compra de equipamentos especiais (elevadores, ar condicionado e outros) e principais suprimentos.

- Nível operacional: está ligado à rotina do canteiro, ou seja, a questões relativas à produção física do empreendimento (ASSUMPÇÃO, 1996).

Segundo Oliveira (2000), esse nível é responsável por identificar constantemente os recursos necessários à execução das tarefas, visando a sua disponibilização antes da execução.

\subsubsection{Interposição das informações nos níveis gerenciais}

No tópico anterior, demonstra-se que as funções dos níveis gerenciais, do ponto de vista da gestão e, consequentemente, da tomada de decisão, diferem consideravelmente de um nível para o outro. Entende-se, com isso, que as informações necessárias para a tomada de decisão também devem ser diferentes, embora, em sistemas integrados para gestão de contratos, o fluxo de informações 
seja único, contínuo e consistente por toda a empresa, sob uma única base de dados (PADILHA et al., 2004).

Como o sistema integrado permite visualizar as transações efetuadas pela empresa desenhando um amplo cenário de seus negócios (PADILHA et. al, 2004), as informações do sistema poderão subsidiar os níveis hierárquicos da organização, possibilitando a rápida tomada de decisão.

Como exemplo, pode-se visualizar, pela Figura 4, que as informações de custo do projeto possuem diferentes abordagens em função do nível de gestão e, portanto, a ferramenta deverá possibilitar essas abordagens.

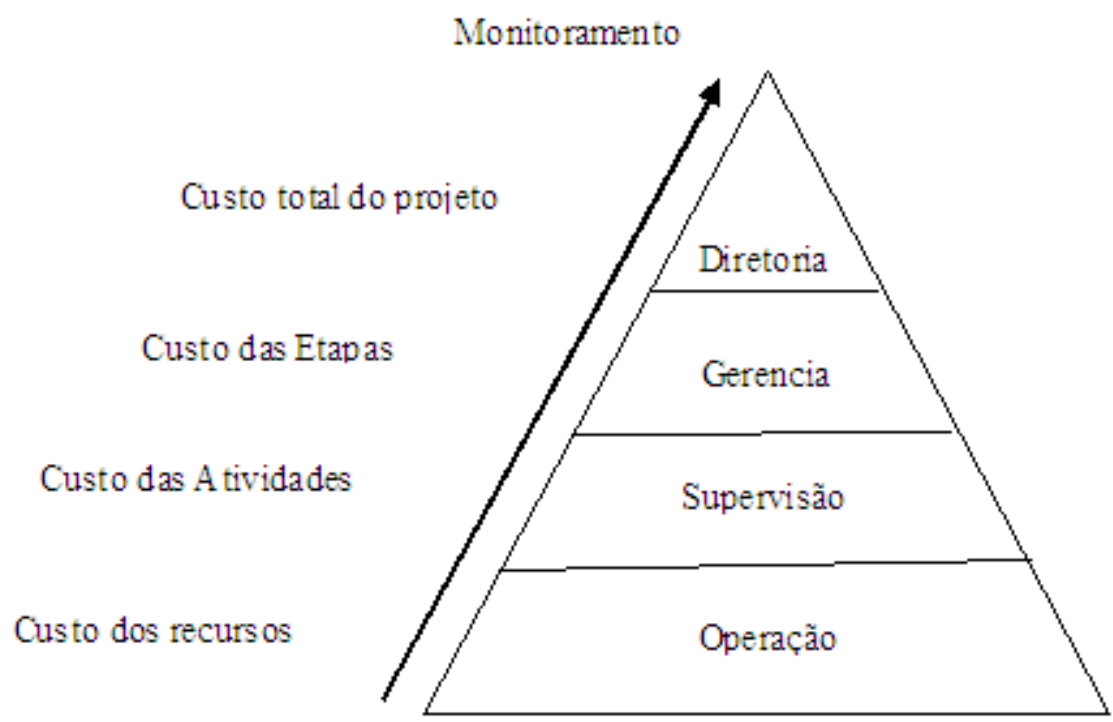

Fonte: adaptação da figura de Ahuja, 1994

Figura 4 - Níveis de informação

Além de possibilitar diversas abordagens, a ferramenta deve ter segurança suficiente para que informações confidenciais não fiquem abertas a qualquer usuário. 
2.1.3. Influência dos níveis gerenciais na implementação de ferramentas de gestão

Turban (2002) orienta que o processo de implementação precede de três fases principais, relacionadas à tomada de decisão, conforme figura 5.

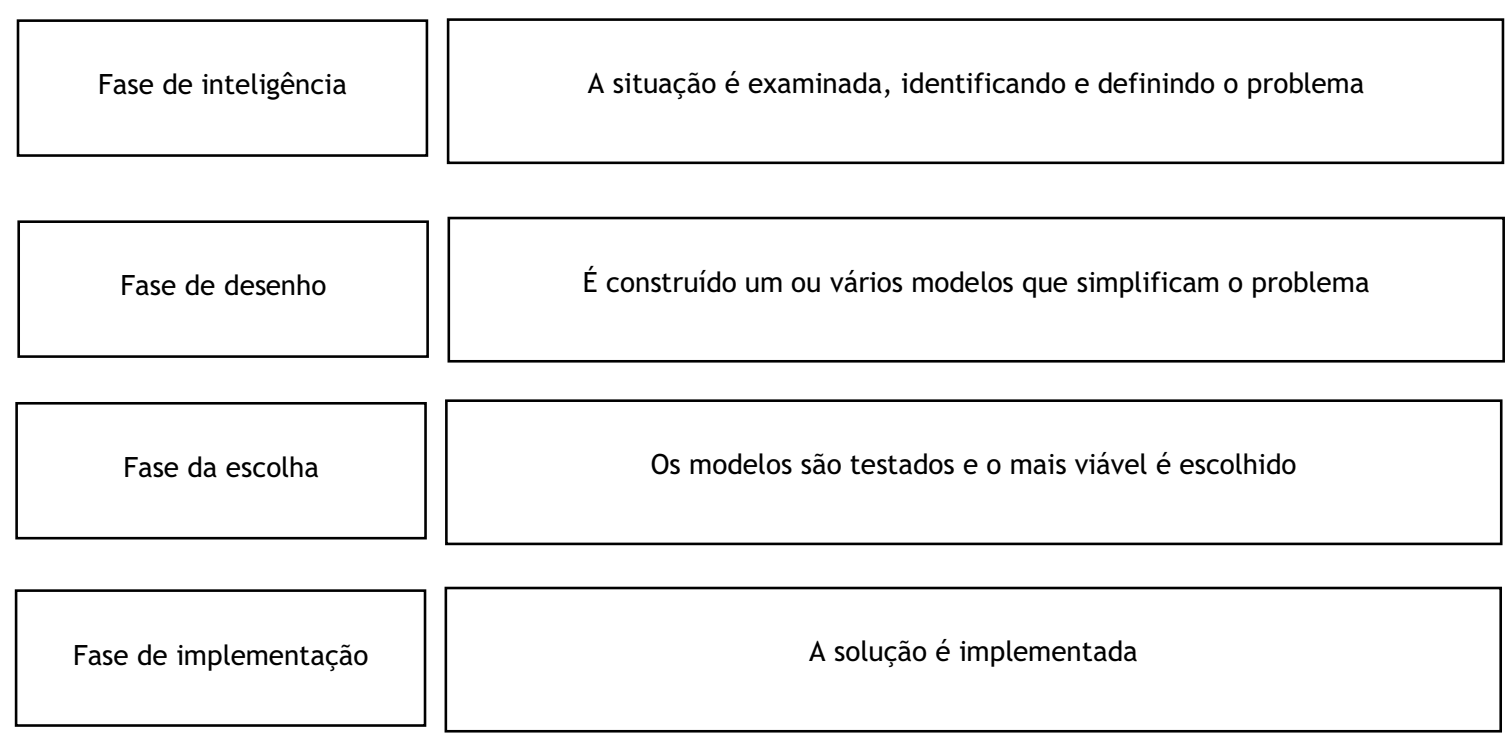

Figura 5 - Fases da implementação (Adaptação TURBAN, 2002)

A influência da implementação de ferramentas que possibilitem uma melhor gestão dos contratos pode ser avaliada nos três níveis identificados, percebendose o seguinte:

\section{- Nível estratégico}

A decisão para a implementação de um sistema integrado para gestão de contratos é, geralmente, resultante de decisões da alta cúpula da empresa (comitê administrativo, acionistas e diretoria), já que requer altos investimentos ${ }^{15}$. Por permitir a governança corporativa, é tida como meta entre os investidores.

\footnotetext{
${ }^{15}$ A implementação do módulo EBS, por exemplo, envolve montantes em torno de 500 mil dólares, conforme contato realizado com empresas implementadoras.
} 
Portanto, a fase de inteligência indicada por Turban (2002) deve ser coordenada por esse nível de gestão. Pois, quando a implementação é iniciada com diretrizes dessa natureza, o processo se torna mais fácil, viabilizando também a transição das informações e garantindo respaldo na cobrança.

Entretanto, o perfil do profissional nesse nível hierárquico deve ser de receptividade a mudanças, propiciando um ambiente salutar para tal investida.

Por outro lado, quando a implementação é respaldada pela alta cúpula, porém o perfil dos profissionais não é o de mudança, mesmo que haja total apoio na implementação, a mudança não é vista de imediato.

Há resistência por parte dos níveis inferiores (tático e operacional), já que os profissionais de nível hierárquico superior também não aderiram à mudança completamente e de imediato. Nesse caso, há morosidade na implementação das mudanças.

\section{- Nível tático}

O nível tático geralmente é responsável pelas fases de desenho, escolha e implementação, conforme Turban (2002). No caso de empresas construtoras, esse nível, geralmente é representado pelos gestores, coordenadores e engenheiros.

Por se tratar de etapas mais relevantes que precedem a implementação, deve-se atentar para a seleção de profissionais comprometidos com a implementação, pois não se pode haver dificuldade nesses processos.

Um profissional que tem resistência a mudar o processo de produção, alegando que sempre fez daquele jeito e deu certo, é mais resistente às mudanças em processos internos da obra e, consequentemente, à implementação de ferramentas de apoio, mesmo sem conhecê-las. 
Tais profissionais, na maioria das vezes, não possuem conhecimento da visão estratégica da empresa e de aspectos relacionados, por exemplo, à governança corporativa.

\section{- Nível operacional}

Os mestres e subempreiteiros não possuem envolvimento direto com a mudança e pouco são afetados por ela.

Já os profissionais da área administrativa e de apoio técnico, geralmente, são os primeiros a perceberem os impactos da mudança, pois são responsáveis, na maioria das vezes, por processos intimamente ligados ao sistema.

Por exemplo, ao se alterar o processo de solicitação de compras, o primeiro profissional envolvido na mudança é o administrativo da obra e/ou o auxiliar técnico que farão o pedido por um processo diferente do habitual.

\subsection{Principais macroprocessos}

O termo "processo" é definido por Souto (2006) como o conjunto de atividades estruturadas e organizadas que são atribuídas aos agentes envolvidos com início e término determinados. Estes, por sua vez, utilizam recursos e, por meio de métodos, produzem saídas orientadas pelas necessidades dos clientes internos dos processos seguintes e, principalmente, do cliente final.

Neste trabalho, o estudo dos principais macroprocessos baseia-se na pesquisa de Cardoso e Vivancos (1999) que citam, em seu artigo, onde foram analisados sete organogramas de empresas construtoras, a existência de três grandes setores funcionais na estrutura dessas empresas. A partir da identificação das unidades 
organizacionais presentes nos organogramas, pode-se concluir sobre suas principais atribuições, conforme quadro 1 apresentado a seguir.

\begin{tabular}{|c|c|c|}
\hline Área & Unidade e número de empresas on & \\
\hline \multirow{6}{*}{ Administrativa } & Recursos Humanos / Pessoal & 6 \\
\hline & Finanças / Contas a pagar e receber & 5 \\
\hline & Contabilidade & 5 \\
\hline & Administração & 3 \\
\hline & Informática & 2 \\
\hline & Suprimentos & 1 \\
\hline \multirow[t]{6}{*}{ Técnica } & Execução de Obras & 6 \\
\hline & Suprimentos & 4 \\
\hline & Planejamento & 3 \\
\hline & Orçamentos & 3 \\
\hline & Almoxarifado & 2 \\
\hline & Projetos * & 1 \\
\hline \multirow[t]{5}{*}{ Comercial } & Desenvolvimento de Novos Negócios & 2 \\
\hline & Marketing & 2 \\
\hline & Licitações & 2 \\
\hline & Orçamenos & 2 \\
\hline & Projetos * & 2 \\
\hline
\end{tabular}

Quadro 1 - Principais unidades organizacionais das empresas estudadas

Analisando as áreas citadas, foram ressaltadas apenas as que estão diretamente ligadas ao processo de gestão de contratos, seja como de apoio ao processo, seja como de contribuição ao sistema, fornecendo dados e informações sobre o projeto, ou ainda, aquelas áreas que apenas trabalham com as informações consolidadas pelo sistema.

Para tal análise, utilizou-se das principais unidades organizacionais relacionadas por Cardoso e Vivancos (1999), ou seja, as que foram identificadas na maioria das construtoras observadas, conforme quadro 2. 


\begin{tabular}{|l|l|c|}
\hline Área & Unidade e número de empresas onde ela foi identificada \\
\hline Administrativa & Recursos Humanos / Pessoal & 6 \\
& Finanças / Contas a pagar e receber & 5 \\
& Contabilidade & 5 \\
\hline Técnica & Execução de Obras & 6 \\
& Suprimentos & 4 \\
& Planejamento & 3 \\
& Orçamentos & 3 \\
\hline
\end{tabular}

Quadro 2 - Áreas mais identificadas na pesquisa de Vivancos e Cardoso (1999)

Além dessa primeira seleção, contou-se com a experiência de profissionais da área de implementação de sistemas e de planejamento e controle, com entrevistas realizadas para identificar as áreas que realmente estão envolvidas nos macroprocessos relacionados à gestão de contratos, conforme quadro 3.

\begin{tabular}{|c|c|c|}
\hline \multicolumn{2}{|c|}{ Áreas das construtoras } & \multirow{2}{*}{\begin{tabular}{|l|}
\multicolumn{1}{|c|}{$\begin{array}{c}\text { Envolvimento no processo de gestão de } \\
\text { contratos }\end{array}$} \\
$\begin{array}{l}\text { Não participa e raramente utiliza-se da } \\
\text { ferramenta em seus processos }\end{array}$ \\
\end{tabular}} \\
\hline \multirow{3}{*}{$\begin{array}{c}\text { Área } \\
\text { Administrativa }\end{array}$} & Recursos Humanos & \\
\hline & $\begin{array}{l}\text { Finanças / Contas a pagar e } \\
\text { receber }\end{array}$ & $\begin{array}{l}\text { Área de apoio ao processo de gestão de } \\
\text { contratos, fornecendo dados e informações para } \\
\text { gestão do contrato }\end{array}$ \\
\hline & Contabilidade & $\begin{array}{l}\text { Área de apoio ao processo de gestão de } \\
\text { contratos, fornecendo dados e informações para } \\
\text { gestão do contrato }\end{array}$ \\
\hline \multirow{4}{*}{ Área Técnica } & Execução de Obras & $\begin{array}{l}\text { Executam o contrato; } \\
\text { Fornecem dados e informações para gestão do } \\
\text { contrato; } \\
\text { Trabalham com as informações consolidadas pelo } \\
\text { sistema. }\end{array}$ \\
\hline & Suprimentos & $\begin{array}{l}\text { Área de apoio ao processo de gestão de } \\
\text { contratos, suprindo a obra dos insumos } \\
\text { necessários para sua execução }\end{array}$ \\
\hline & Planejamento & $\begin{array}{l}\text { Fornecem dados e informações para gestão do } \\
\text { contrato; } \\
\text { Trabalham com as informações consolidadas pelo } \\
\text { sistema fazendo o acompanhamento e controle. }\end{array}$ \\
\hline & Orçamentos & Área de apoio ao processo de gestão de contratos \\
\hline
\end{tabular}

Quadro 3 - Envolvimento das áreas de empresas construtoras no processo de gestão de contratos (proposição da autora) 
Com base nessa classificação, pôde-se separar as áreas, conforme quadro 4.

\begin{tabular}{|c|}
\hline ÁREAS DE APOIO AO PROCESSO DE GESTÃO DE CONTRATOS \\
\hline Orçamento \\
Suprimentos \\
Financeira \\
\hline Contabilidade \\
\hline ÁREA RELACIONADA À EXECUÇÃO DO CONTRATO / PROJETO \\
\hline Execução de Obras \\
\hline ÁREA RELACIONADA AO PLANEJAMENTO E CONTROLE DOS CONTRATOS \\
\hline Planejamento e Controle \\
\hline
\end{tabular}

Quadro 4 - Macroprocessos típicos das empresas construtoras

A partir dessa classificação, pretende-se discorrer sobre os macroprocessos das áreas, especificamente, os relacionados com a gestão de contratos.

\subsection{1. Áreas de apoio ao processo de gestão de contratos}

\section{- Orçamento}

Mattos (2006) salienta que, em grandes organizações, existem setores dedicados exclusivamente a preparar orçamentos para concorrências públicas ou privadas, observando que uma boa prática que se tem revelado satisfatória, em algumas empresas, é designar o responsável pela obra, ainda na fase de elaboração da proposta. 
Verifica-se, ainda, que a área de orçamento utiliza-se, muitas vezes, de informações de obras passadas como subsídio para novas propostas que, na maioria das vezes, são geradas em programas específicos para a elaboração de orçamentos.

Dentre as tarefas da área de orçamento, algumas possuem relação direta com o sistema de gestão de contrato e serão detalhadas. São elas:
a. Definir a estrutura analítica de projeto
b. Cadastrar a quantidade e insumos nas tarefas
C. Cadastrar o custo dos insumos
d. Valorizar ${ }^{16}$ o orçamento de custo e venda

\section{a. Definir a estrutura analítica de projeto}

De posse dos projetos da obra a ser orçada, o orçamentista necessitará organizar as informações. Para tal, muitas vezes, é criada uma EAP - Estrutura Analítica de Projeto $^{17}$, quando ela não é fornecida pelo cliente.

Por intermédio dessa estrutura, os serviços do orçamento serão organizados.

\section{b. Cadastrar a quantidade e insumos nas tarefas}

Com base na análise da documentação do projeto executivo, devem ser levantadas as quantidades necessárias de recursos, para cada tarefa da EAP, as quais deverão ser relacionadas de forma que se possa ter visibilidade da relação de recursos previstos para uma determinada tarefa, com sua respectiva quantidade.

\footnotetext{
${ }^{16}$ Valorizar: entende-se como o ato de atribuir valores de custo e venda aos itens do orçamento.

${ }^{17}$ Veja a definição de EAP no capítulo 3 Definição e diagnóstico das práticas de gestão de contratos.
} 


\section{Cadastrar o custo dos recursos}

Cabe ressaltar que os custos unitários poderão variar de projeto para projeto. Portanto, é necessário que cada projeto tenha a sua lista de recursos com os seus respectivos preços por projeto.

\section{d. Valorizar o orçamento de custo e venda}

Os custos unitários dos insumos são apontados conforme pesquisa de mercado ou base de dados da empresa e, após seu cadastramento, é possível obter a informação de custo global, detalhado conforme a EAP previamente definida.

Para a determinação do valor de venda ${ }^{18}$, após definido o BDI - Benefício e Despesas Indiretas ${ }^{17}$, ou seja, lucro, administração de canteiro, mão-de-obra indireta (gerente, coordenadores, engenheiros, auxiliares e etc.), contingências, impostos, seguros e etc, ele é aplicado sobre o custo, resultando no valor de venda.

Após as atividades anteriormente mencionadas e, principalmente, após as definições do valor de custo e venda, o orçamento ou a proposta passam por aprovação do nível estratégico da empresa.

O cenário ideal seria o da carga do orçamento de custo e venda, assim que a proposta fosse aprovada, alimentando automaticamente o sistema de gestão de contratos como baseline ${ }^{17}$.

\section{- Suprimentos}

A área de suprimentos é uma das funções organizacionais que recebe atenção especial das construtoras, já que, por intermédio dela, circulam grande parte dos recursos financeiros da empresa construtora, por estar diretamente ligada à produção, ou seja, às obras. Se a empresa de construção for considerada um

${ }^{18}$ Veja a definição no capítulo 3 Definição e diagnóstico das práticas de gestão de contratos. 
sistema, a função de compras será um subsistema, que terá como objetivo principal atender as necessidades da produção (JUNGLES, 2008).

Burt e Pinkerton (1996) apud Jungles (2008) esclarecem que a função de “compras", como também é conhecida a área de suprimentos, tem a responsabilidade de suprir as necessidades de compras, por meio de um planejamento quantitativo e qualitativo, que possibilite o recebimento do material, no momento certo, com as quantidades corretas.

Dentre as diversas funções da área de suprimentos, Stukhart (1995), apud Jungles (2008) destaca:
a. Qualificação e seleção de fornecedores;
b. Solicitação de cotações;
C. Negociação com fornecedores;
d. Avaliação e aprovação de cotações;
e. Negociações com fornecedores e formulação de pedidos e contratos.

Com relação à integração dos processos de compras, com o planejamento e controle da obra, Goldman (2004) recomenda que as construtoras montem um sistema integrado do tipo planejamento-obra-compra, de forma que os pedidos de materiais, feitos pelas obras, sejam sempre conferidos pelo setor de planejamento. Assim, seriam analisados, não permitindo compras desnecessárias para a execução.

Ainda, analisando os processos acima relacionados, verifica-se que, entre a obra solicitar um determinado material e este chegar ao canteiro, existe um longo processo que, na maioria das empresas, é automatizado.

O processo geralmente nasce com a solicitação de fornecimento, gerada pela obra e termina com a entrega do material no canteiro. Observa-se, então, uma oportunidade de integração com o sistema de gestão de contratos, visto que, para se saber a necessidade de material, é recomendável que se analise o cronograma 
das atividades (prazos) e também o orçamento previsto (tanto quantidade como valores).

\section{- Contabilidade}

Marion (2005) esclarece que muitos acreditam que a contabilidade é um setor que foi criado apenas para satisfazer as exigências fiscais. Entretanto, ressalta-se que a função básica da área de contabilidade é produzir informações úteis para a tomada de decisões.

E define a contabilidade de custos da seguinte forma:

A contabilidade de custos é integrante do processo administrativo $e$ proporciona à administração registros dos custos dos produtos $e$ operações, possibilitando comparar os custos reais com os orçamentos. (MARION, 2005)

Goldman (2004) observa que, no setor contábil, são geradas as informações relativas às despesas reais da construção, sendo estas relevantes na avaliação, planejamento e controle dos custos das obras. Tais informações são codificadas por item de serviços e apropriadas conforme plano de contas, que geralmente é organizado para se adequar às construções em geral, podendo, dessa forma, ser utilizado para todas as tipologias construtivas.

Portanto, a área contábil é responsável por desenvolver e prover dados para mensurar a performance da empresa, contabilizando, todo seu patrimônio, elaborando demonstrações e reconhecendo as receitas no momento em que são incorridos os gastos. Ou seja, a contabilidade considera os valores do regime de competência ou também conhecido como econômico, onde o registro de valores é feito na data/mês em que o documento é contabilizado (SANTIN DE SOUZA, 2006).

Por gerar dados próximos à precisão, já que eles possuem aspecto legal, as informações são essenciais para análises do custo real $x$ custo previsto e da receita real $x$ receita prevista. Portanto, são de grande importância, 
principalmente se essas informações forem integradas ao sistema de gestão de contratos.

\section{- Financeira}

Enquanto a área contábil, explanada anteriormente, é responsável por desenvolver e prover dados para mensurar a performance da empresa, a área financeira enfatiza o fluxo de caixa. Esse é nada mais que a entrada e saída de dinheiro, que demonstrará realmente a situação e a capacidade financeira para satisfazer as obrigações e adquirir novos ativos (bens ou direitos de curto ou longo prazo) a fim de atingir as metas da empresa (SANTIN DE SOUZA, 2006).

Tanto quanto as informações econômicas, as informações financeiras são essenciais na tomada de decisão e no controle das despesas e recebimento sobre o enfoque do caixa também conhecido como dados financeiros, que consiste no registro de valores na data/mês em que o documento é pago, ou recebido, ou seja, quando há saída ou entrada de valor no caixa.

\subsection{2. Área de execução do contrato ${ }^{19}$}

A área de execução do projeto é a obra e possui uma série de atividades, porém serão apresentadas a seguir apenas as atividades relacionadas à gestão do contrato, ou seja:

a. Solicitação de compras e contratações para realização do contrato

b. Controle das contratações e custos incorridos

c. Controle dos prazos

\footnotetext{
${ }^{19}$ Entende-se também como área de execução do projeto.
} 


\section{a. Solicitação de compras e contratações}

Nesse processo, os profissionais da área de planejamento operacional da obra deverão analisar os projetos e orçamentos e priorizar as compras e contratações, conforme cronograma de execução da obra. Após o levantamento da real necessidade de compra ou contração, a solicitação de fornecimento deverá ser encaminhada à área de suprimentos com as devidas especificações do item a ser comprado ou contratado.

Após o fechamento do contrato ou a compra, o gestor deverá cuidar dos fornecimentos na obra. Por exemplo, para fornecimento do concreto, geralmente é fechado um contrato, e as entregas são realizadas parcialmente conforme a necessidade da obra. O gestor deverá, com relação à quantidade de concreto recebida e a quantidade faltante, controlar o saldo do contrato e a eventual necessidade de aditivo com o fornecedor.

Verifica-se que o referido controle é efetuado, por algumas obras, em planilha excel, quando, na verdade, poderia ser realizado pelo sistema.

\section{b. Controle das contratações e custos incorridos}

No caso de execução de serviços, é necessário que haja um controle dos itens contratados, com respectivas quantidades e preços contratados. Como a execução de um determinado serviço pode se estender por vários meses, é importante ter a visão das quantidades e faturamentos previstos e executados mês a mês.

Após a realização dos serviços ou o recebimento dos materiais no canteiro, geralmente é feito o lançamento dos dados relativos à Nota fiscal/fatura para a realização dos processos relativos ao pagamento e contabilização. Esse lançamento é apropriado conforme plano de contas contábil e, com isso, o gestor da obra pode ter uma visão dos custos realizados (incorridos), ou seja, aqueles 
que já estão em trâmite de pagamento e os que já foram pagos, podendo, dessa forma, comparar os custos previstos com aqueles realizados.

Com relação a esse ponto, vale a pena salientar a orientação de Goldman (2004) em apropriar-se os custos incorridos nas respectivas etapas construtivas.

Para se observar os custos incorridos nas respectivas etapas há dois processos possíveis:

- No momento do registro da nota fiscal, relativa aos materiais ou serviços recebidos, deve-se apropriá-los nas etapas construtivas em que serão utilizados. Exemplo: considerando-se que o concreto foi utilizado para fundação do bloco A e concretagem da $2^{a}$ laje do bloco $B$, deve-se apropriar a nota fiscal de concreto, com $60 \%$ do valor da nota fiscal na etapa de fundações e $40 \%$ na etapa de estrutura.

- No momento da saída do material do estoque, a construtora deverá ter, além do controle de lançamento das notas fiscais, o controle de estoque com as respectivas baixas realizadas. Nesse caso, devem ser tratadas as exceções, por exemplo, o concreto citado anteriormente não passa pelo estoque.

Não se pretende, neste trabalho, discorrer sobre a melhor forma de apropriação, mas observar que, com a possibilidade de visualização pelo sistema do custo orçado por etapa construtiva e do custo incorrido, o engenheiro poderá tomar a decisão, por exemplo, de reorçar a obra para verificar se o custo total previsto continua dentro do previsto inicialmente, comparando o custo realizado atual com o orçamento original.

Esse detalhe de processo deve ser observado no momento da implementação do sistema, pois está diretamente relacionado com o resultado a ser apresentado na ferramenta. Apropriações de custos em etapas construtivas de forma aleatória não permitirão análise comparativa no decorrer do projeto. 


\section{c. Controle dos prazos}

É muito comum, tanto em clientes públicos como privados, que ocorram reuniões semanais ou, no mínimo, mensais, para acompanhamento dos trabalhos executados e prazos previstos. Em obras públicas é usual o acompanhamento semanal dos fiscais.

Para essa atividade, geralmente, conta-se com o apoio do engenheiro de planejamento e controle, que atualiza o cronograma de execução com o avanço físico ${ }^{20}$ e analisa se o andamento dos serviços está conforme o previsto.

Com essas informações, o gestor do contrato, muitas vezes, necessita fazer um replanejamento, para conseguir trazer a data de término do contrato para a prevista. É comumente analisada a possibilidade de se aumentar a equipe, trabalhar nos finais de semana e feriados ou ainda aumentar um turno de trabalho. Essas análises devem ser acompanhadas de um reorçamento, de forma que o prazo seja atingido, sem que a margem do contrato seja comprometida.

As atividades descritas acima são de grande relevância para a gestão do contrato, e, portanto, poderiam ser realizadas diretamente pelo sistema de gestão.

\subsection{3. Áreas de planejamento e controle dos contratos}

Hartman e Skulmoski (1999) dividem as competências da equipe de planejamento e controle de um projeto em dois elementos principais: o desenvolvimento e o gerenciamento do cronograma do projeto.

Entretanto, as tarefas da área de planejamento e controle não se restringem apenas ao desenvolvimento e ao gerenciamento do cronograma do projeto, mas também às seguintes atividades:

\footnotetext{
${ }^{20}$ Veja a definição do termo no capítulo 3 Definição e diagnóstico das práticas de gestão de contratos.
} 
a. Organização dos dados iniciais para controle do projeto

b. Definição da EAP para controle físico e financeiro da obra

c. Planejamento e controle físico e financeiro da obra

\section{a. Organização dos dados iniciais para controle do projeto}

Por meio dessa atividade, consolidam-se, com o uso de planilha orçamentária de custo e venda, as informações para controle do projeto.

Com as informações iniciais geradas pela área de orçamento da empresa, são elaborados os cronogramas, tanto para acompanhamento físico, como financeiro do projeto. Também são elaborados histogramas de mão-de-obra e de equipamentos.

Essa tarefa é comumente realizada por profissionais de planejamento e controle, com o apoio do engenheiro da obra. Nos casos da área de planejamento e controle ser centralizada, o profissional da sede da construtora apoiará a obra. No caso de ser descentralizada, o próprio engenheiro da obra é responsável por elaborar as informações.

\section{b. Definição da EAP para controle físico e financeiro da obra}

Geralmente, a EAP ${ }^{21}$ para controle físico e financeiro da obra é a mesma utilizada pela área de orçamento, na fase de proposta.

É comum que os profissionais de planejamento e controle definam o nível de controle do projeto, por exemplo: se a obra for habitacional e possuir vários blocos, a área de planejamento deverá definir o nível de detalhamento do cronograma e, consequentemente, do controle.

\footnotetext{
${ }^{21}$ Veja a definição de EAP no capítulo 3 Definição e diagnóstico das práticas de gestão de contratos.
} 


\section{c. Planejamento e controle físico-financeiro da obra}

Para planejamento e controle físico-financeiro, utiliza-se dos elementos descritos nos tópicos anteriores, sendo recomendável e mais utilizado, conforme entrevistas com profissionais da área de planejamento e controle, o seguinte:

Nível de detalhamento para acompanhamento físico: o cronograma de planejamento terá o mesmo nível de detalhamento do cronograma de controle (acompanhamento).

Nível de detalhamento para acompanhamento financeiro (custo e receita): os custos e receitas são controlados num nível macro, porém seguindo a mesma EAP.

Na Figura 6, é exemplificado esse tipo de planejamento e controle. 


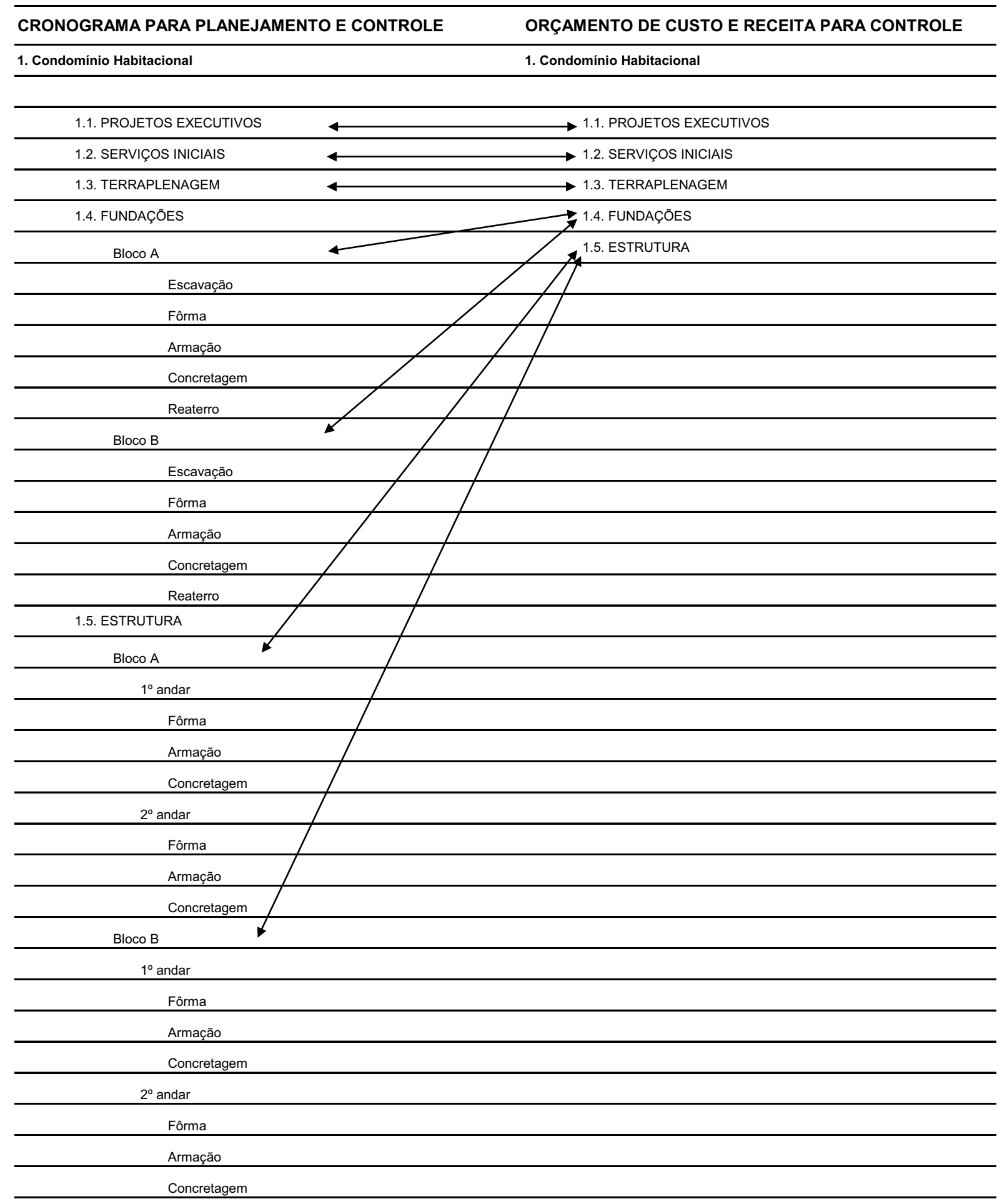

Figura 6 - Exemplo de Controle Físico e Financeiro

Cabe ressaltar que, no caso de haver distorções de custo ou receita entre os valores planejados e os valores realizados, não será possível identificar com precisão a causa. 
Com relação ao sistema de gestão de contratos, entende-se que as informações geradas pela área de planejamento e controle são essenciais e poderiam estar contidos no sistema, permitindo uma rápida tomada de decisão por parte do gestor do contrato. 
Planejar é fazer escolhas.

E depois de ter escolhido,

controlar é garantir as escolhas feitas.

Lachman (1993)

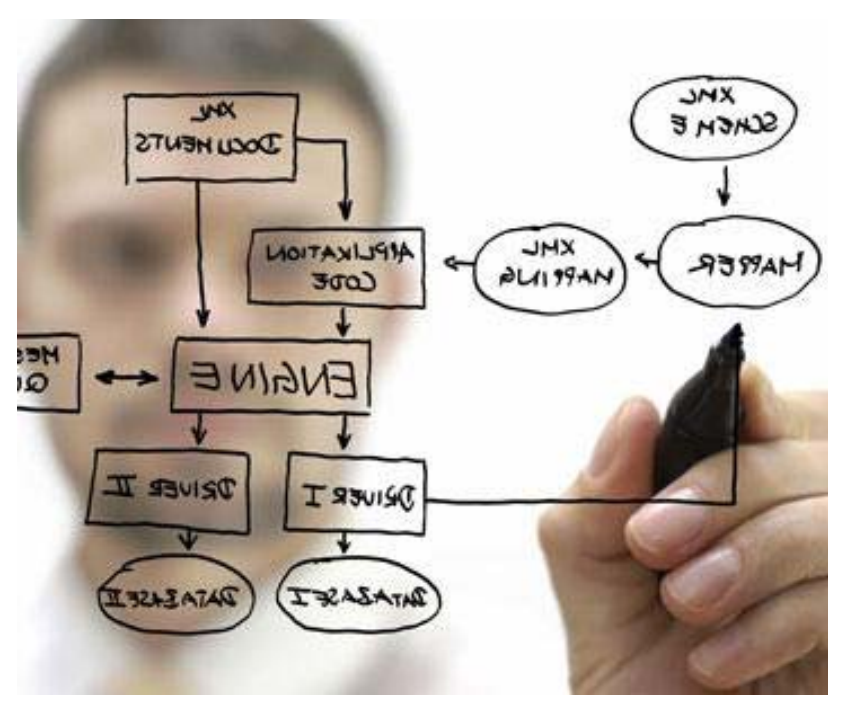




\section{Definição e diagnóstico das práticas de gestão de contratos}

Neste capítulo, são apresentadas as definições e os diagnósticos das práticas de gestão de contratos, primeiramente, analisando e conceituando o termo "práticas" dentro do "processo" de "gestão".

A partir desta análise introdutória, verifica-se que as práticas de gestão do projeto poderiam ser divididas em dois tópicos principais, um relacionado às práticas de planejamento do projeto e outros às práticas de controle e monitoramento do projeto.

Ainda, neste capítulo, considerando a importância do conhecimento preliminar das práticas de gestão, já que para a implementação de ferramenta é necessário que se analise a sua aderência aos processos da construtora, torna-se imprescindível a conceituação dos elementos essenciais para o planejamento e controle.

Para tanto, são apresentados inicialmente os elementos de planejamento, como: EAP - Estrutura Analítica de Projeto, EAR - Estrutura Analítica de Recursos, cronograma do projeto, linha de base, gráfico de gantt, conceituação e distribuição do Custo e Receita.

$\mathrm{Na}$ sequência, são detalhados os elementos relativos ao controle do projeto, como o avanço físico das tarefas e, consequentemente, da obra, ponderação de avanço físico e, por fim, as análises para desempenho geral do projeto, focando a análise de valor agregado e os indicadores de prazo, custo e tendência para a conclusão.

Cabe destacar que, neste trabalho, não se pretende apresentar todas as práticas utilizadas em empresas construtoras, mas as mais comuns identificadas nas entrevistas realizadas com profissionais da área de planejamento e controle. 


\subsection{Práticas de gestão de contratos}

As práticas são definidas por Michaelis (2010) como a forma de agir ou de fazer as coisas, e o processo, como o conjunto de atos ou práticas pelas quais se realiza uma operação.

Portanto, para a implementação de qualquer sistema ou nova tecnologia é necessário que se conheça preliminarmente as práticas que compõem o processo, ou seja, os procedimentos da maneira de se agir em todas as etapas do processo.

Embora, Howell e Koskela (2000) tenham concluído, em seu artigo, sobre a reforma no gerenciamento de projetos, a sua prática de gerenciamento sofre com suposições erradas e teorias idealizadas. Destacam que, em projetos pequenos, simples e com curto prazo de execução, os problemas poderiam ser resolvidos informalmente e sem medidas tão amplas. Entende-se que a aplicação de práticas de gestão deve ocorrer em qualquer projeto, independente do seu porte.

Howell e Koskela (2000) ainda observam que uma teoria deficiente é a raiz dos problemas da gestão de projetos e que primeiramente se deve resolver os problemas da teoria, para que se possa resolver os problemas da prática.

Com isso, para a implementação de um sistema integrado de gestão de contratos, é imprescindível o estudo teórico, definindo e diagnosticando as práticas relativas ao processo de gestão de contratos para posteriormente aplicá-las no sistema.

Outro ponto importante relacionado às práticas de gestão de projetos é que existe mais de uma maneira de se gerenciar um projeto, conforme Kerzner (2004) e PMBOK (2008).

Os profissionais mais experientes de gerenciamento de projetos reconhecem que existe mais de uma maneira de gerenciar um projeto. (PMBOK, 2008, p.40) 
Não se pretende expor, neste trabalho, todas as práticas disponíveis, mas apresentar as mais comuns utilizadas nas empresas de construção civil em contratos de obras e, posteriormente, a aplicabilidade dessas práticas no sistema de gestão analisado ${ }^{22}$.

Para um melhor entendimento, as práticas relacionadas à gestão de contratos serão separadas em dois tópicos, um relacionado ao planejamento e outro, ao controle.

Com relação aos assuntos neles abordados, foram realizadas entrevistas com profissionais especialistas na área de planejamento e controle e que atuam no mercado há mais de 10 anos, sendo identificados os elementos essenciais conforme a sua utilização e necessidade.

\subsection{Planejamento do projeto}

De acordo com Bateman (1998), planejar é especificar os objetivos a serem atingidos e decidir antecipadamente as ações apropriadas que devem ser executadas para atingir esses objetivos.

Para a execução de qualquer projeto é necessário que exista um planejamento, que defina o método de execução do projeto; a programação, que gerará o cronograma da execução; e o controle, que permitirá o acompanhamento e verificação do andamento do projeto (LOSSO et al., 1995 apud MORAES et al., 2009).

De forma mais abrangente, o PMBOK (2008) define o grupo de processos de planejamento como aquele que define e refina os objetivos e planeja a ação necessária de criação de um plano de gerenciamento.

\footnotetext{
${ }^{22}$ EBS - E-Business Suite.
} 
Mattos (2010) ressalta:

[...] O planejamento da obra é um dos principais aspectos do gerenciamento, conjunto de amplo espectro, que envolve também orçamento, compras, gestão de pessoas, comunicações e etc. Ao planejar, o gerente dota a obra de uma ferramenta importante para priorizar suas ações, acompanhar o andamento dos serviços, comparar o estágio da obra com a linha de base referencial e tomar providências em tempo hábil quando algum desvio é detectado. (MATTOS, 2010, p.17)

Almeida (2006) sugere ainda um roteiro para elaboração do planejamento de projetos, conforme Quadro 5.

\begin{tabular}{|c|}
\hline ROTEIRO DO PLANEJAMENTO \\
\hline Detalhar o escopo do projeto \\
\hline Identificar as interdependências entre atividades \\
\hline Estimar durações \\
\hline Identificação do caminho crítico \\
Geração do cronograma \\
\hline Geração do cronograma e cálculo das folgas \\
\hline Desenvolver o orçamento do projeto
\end{tabular}

Com isso, percebe-se que Almeida (2006), em seu roteiro, foca não apenas os elementos relativos ao planejamento físico da obra, mas também ao financeiro, quando se refere ao orçamento do projeto.

Portanto, para estudo dos principais elementos que compõem o planejamento de uma obra, preferiu-se separar o planejamento em dois tópicos principais: Planejamento Físico e Planejamento Financeiro. 


\subsubsection{Planejamento físico}

Tomando-se por base o roteiro de planejamento identificado por Almeida (2006) e também as entrevistas realizadas com profissionais de planejamento e controle, são relacionados, abaixo, os elementos mais relevantes para o planejamento físico e, consequentemente, devem compor o sistema de gestão de contratos.
a. EAP - Estrutura Analítica de Projeto
b. EAR - Estrutura Analítica de Recursos
C. Organização das Atividades
d. Linha de Base
e. Gráfico de Gantt
f. Cronograma do Projeto

\section{a. EAP - Estrutura Analítica de Projeto}

De acordo com o PMBOK (2008), a EAP - Estrutura Analítica de Projeto, também chamada de WBS - Work Breakdown Structure, constitui uma decomposição hierárquica orientada à entrega do trabalho a ser executado pela equipe do projeto para atingir seus objetivos e criar as entregas necessárias. A EAP estrutura e define o escopo total do projeto, sendo que cada nível descendente representa uma definição cada vez mais detalhada do trabalho do projeto.

Além disso, vale ressaltar que a EAP, segundo PMBOK (2008), subdivide os trabalhos do projeto em partes menores e mais facilmente gerenciáveis.

Na Figura 7, a seguir, é exemplificada a decomposição da EAP até o menor nível da estrutura, no caso, pacotes de trabalho ${ }^{23}$.

\footnotetext{
${ }^{23}$ Pacotes de trabalho $=$ pacotes de contratação $($ work package $)$.
} 


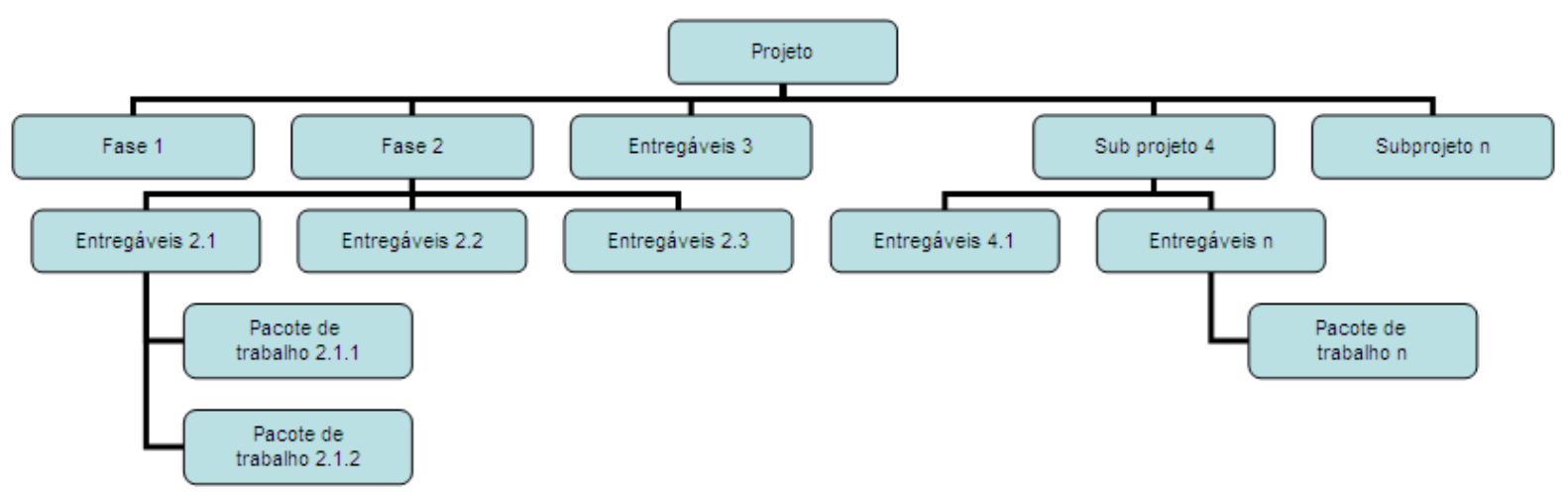

Figura 7 - Exemplo de EAP com ramais decompostos até o nível de pacotes de trabalho (Adaptação do PMBOK, 2008)

Almeida (2006) caracteriza a EAP como sendo uma divisão natural do projeto, e destaca que ela é vital e indispensável, devendo ser utilizada durante todo o projeto, desde a fase de orçamento e planejamento até a execução e controle.

Nocêra (2006) resume, em poucas palavras, que EAP é uma síntese estrutural do projeto, ou seja, a divisão das atividades em níveis que permitam o controle.

Portanto, entende-se por EAP a organização das etapas, atividades e serviços da obra, de forma que representem a sua sequência executiva. Ela deverá ser completa, organizada e com um nível de detalhamento suficiente para que o progresso possa ser medido, mas não detalhada o suficiente para se tornar, ela mesma, um obstáculo para a realização do projeto devido à dificuldade de acompanhamento.

Como exemplo, no quadro 6, detalham-se as atividades e serviços da etapa de fundações e estrutura. 


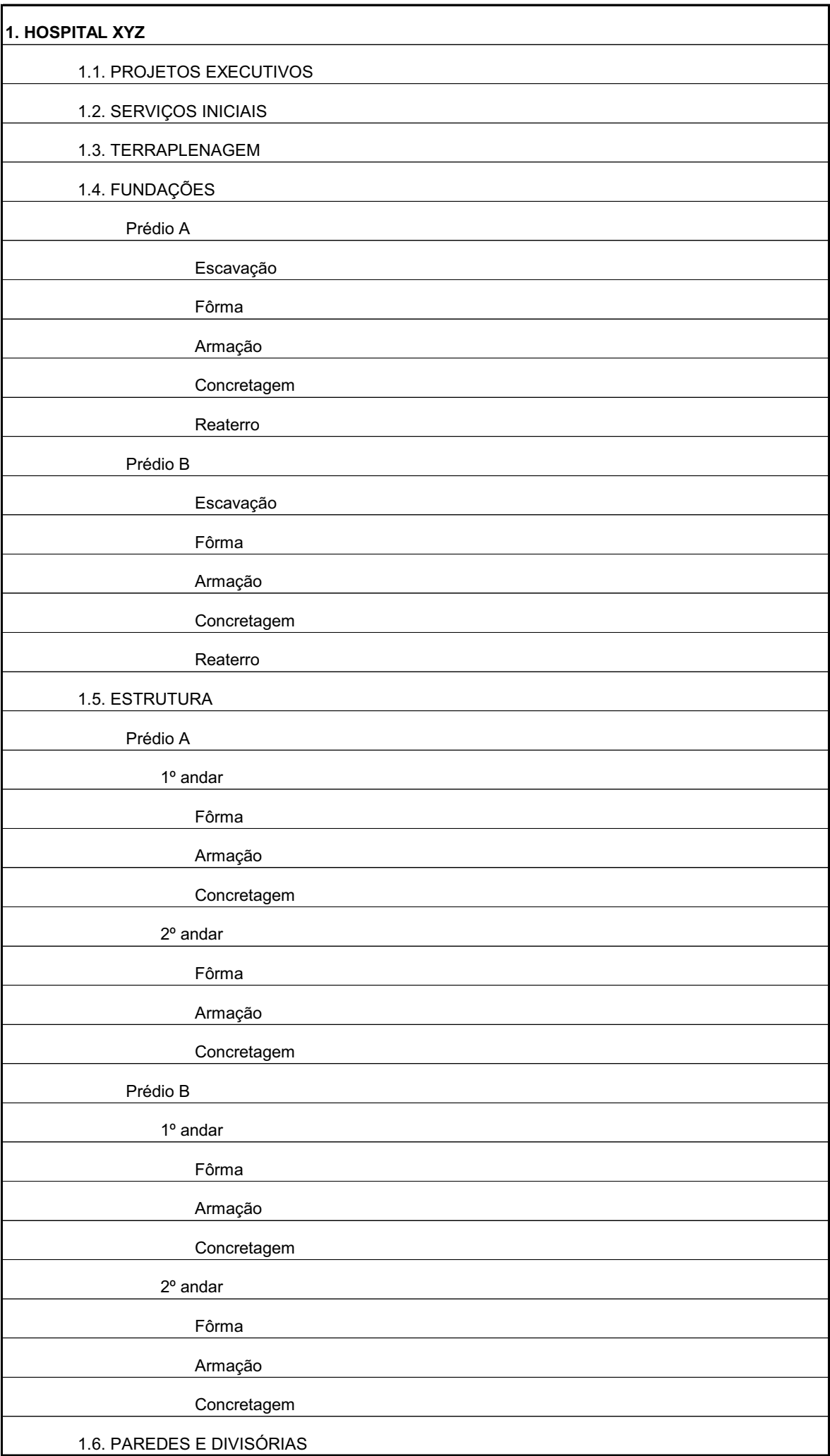

Quadro 6 - Exemplo de detalhamento da EAP das etapas de fundações e estrutura

Por estar diretamente relacionada aos trabalhos do projeto, a EAP poderá ser diferenciada de projeto para projeto. A NASA (1994), por exemplo, é responsável 
pela elaboração das EAP dos seus projetos. No caso de obras de construção civil é bastante comum que elas sejam diferentes, devido às suas especificidades. Por exemplo, a EAP da construção de um túnel certamente será diferente da EAP da construção de um edifício, que será diferente da construção de uma estrada.

\section{b. EAR - Estrutura Analítica de Recursos}

A EAR - Estrutura Analítica de Recursos ou RBS - Resource Breakdown Structure é definida pelo PMBOK (2008) como a estrutura hierárquica dos recursos por categoria, que pode ser utilizada para identificar e analisar designações de recursos humanos do projeto.

Porém, a EAR não deve se limitar apenas à organização dos recursos humanos do projeto, mas também à organização de recursos materiais e equipamentos, já que num projeto de construção civil tais elementos são essenciais.

Bernardes (2010) define, baseando-se no MS-Project, que os recursos podem ser elementos humanos, materiais e financeiros que podem estar associados às atividades do cronograma de um empreendimento.

Já, a Pini (2008) utiliza uma organização de recursos mais detalhada, denominada de natureza do item. No quadro 7 é apresentada a classificação completa dos recursos, embora alguns não sejam muito utilizados na organização de banco de dados, como por exemplo: depreciação, juros do capital, manutenção de equipamentos e diversos. 


\begin{tabular}{|c|c|}
\hline Natureza do item & Descrição \\
\hline 1 - Mão-de-obra & Trata-se da mão-de-obra própria da construtora \\
\hline 2 - Empreitada & $\begin{array}{l}\text { Refere-se à contratação da mão-de-obra de um serviço } \\
\text { junto a terceiros }\end{array}$ \\
\hline 3 - Verba & $\begin{array}{l}\text { Valor estimado do serviço para itens ainda não } \\
\text { definidos em projeto ou que não se enquadram em } \\
\text { nenhuma das classificações aqui apresentadas. } \\
\text { Exemplo: taxas da prefeitura }\end{array}$ \\
\hline 4 - Material & Refere-se à aquisição de material \\
\hline 5 - Equipamento aquisição & $\begin{array}{l}\text { Refere-se à aquisição de equipamentos para própria } \\
\text { obra }\end{array}$ \\
\hline $\begin{array}{l}6 \text { - Serviço (material e } \\
\text { mão-de-obra) }\end{array}$ & $\begin{array}{l}\text { Significa que o serviço contratado inclui } 0 \\
\text { fornecimento dos materiais e da mão-da-obra para sua } \\
\text { total execução }\end{array}$ \\
\hline 7 - Equipamento locação & $\begin{array}{l}\text { Refere-se à locação de equipamentos para própria } \\
\text { obra }\end{array}$ \\
\hline 8 - Serviço composto & Trata-se da composição de serviços \\
\hline $\begin{array}{l}9 \text { - Custo horário de } \\
\text { equipamentos }\end{array}$ & $\begin{array}{l}\text { São composições de custo para hora produtiva e } \\
\text { improdutiva de máquinas e equipamentos. Nas } \\
\text { composições de hora produtiva, levam-se em conta } \\
\text { todos os insumos necessários para sua operação } \\
\text { (combustível, pneus, manutenção, mão-de-obra) além } \\
\text { da depreciação e os juros do capital (remuneração). } \\
\text { Nas composições de horas improdutivas, são } \\
\text { considerados apenas a depreciação, os juros do capital } \\
\text { e a mão-de-obra, ou seja, o custo da hora parada e } \\
\text { equipamento }\end{array}$ \\
\hline 10 - Depreciação & $\begin{array}{l}\text { Utilizado nas composições de Custo horário de } \\
\text { equipamentos }\end{array}$ \\
\hline 11 - Juros do capital & $\begin{array}{l}\text { Utilizado nas composições de Custo horário de } \\
\text { equipamentos }\end{array}$ \\
\hline 12 - Manutenção do equipamento & $\begin{array}{l}\text { Utilizado nas composições de Custo horário de } \\
\text { equipamentos }\end{array}$ \\
\hline 13 - Diversos & $\begin{array}{l}\text { Trata-se de tipo de recursos que não se classificam em } \\
\text { nenhuma das anteriores }\end{array}$ \\
\hline
\end{tabular}

Quadro 7 - Classificação dos recursos conforme TCPO (2008) 
Almeida (2006) classifica os recursos nas seguintes categorias:

\begin{tabular}{|c|c|}
\hline CATEGORIA & EXEMPLO \\
\hline Mão-de-obra & $\begin{array}{r}\text { São os recursos humanos necessários para o } \\
\text { projeto (quadro de funcionários) }\end{array}$ \\
\hline Material consumível & $\begin{array}{c}\text { Representa os recursos consumíveis ou bens não } \\
\text { depreciáveis, aqueles que se extinguem durante } \\
\text { a execução da tarefa }\end{array}$ \\
\hline Equipamento & $\begin{array}{c}\text { São os recursos renováveis ou bens depreciáveis, } \\
\text { podendo ser reutilizados em mais de uma tarefa } \\
\text { do mesmo projeto }\end{array}$ \\
\hline Empreiteiro & $\begin{array}{c}\text { São os recursos, geralmente externos à } \\
\text { organização executora, que trabalham sob o } \\
\text { regime de empreitada por preço fixo }\end{array}$ \\
\hline
\end{tabular}

Quadro 8 - Categorias de recursos (ALMEIDA, 2006)

Cabe destacar, que não se pretende, neste trabalho, definir uma forma de classificação adequada para os recursos do projeto, mas ressaltar que a classificação dos recursos permite a organização do banco de dados da ferramenta, possibilitando a consolidação de informações de forma mais eficiente. Portanto, as tabelas apresentadas são sugestivas, podendo ser utilizadas de referência em implementações posteriores.

\section{c. Organização das Atividades}

Segundo Antill e Woodhead (1990), a representação gráfica das atividades, levando em conta as dependências entre elas, chama-se diagrama de rede, que nada mais é do que a representação gráfica das atividades organizadas conforme sequência executiva da obra. 
Antill, Woodhead (1990), PMBOK (2004) e também Cardoso (2009) recomendam os dois métodos "mais empregados" para organização do sequenciamento das atividades. São eles:

- MDP - Método do diagrama de precedência ou PDM (precedence diagramming method): consiste na construção de um diagrama de rede do projeto.

- MDS - Método do diagrama de setas ou ADM (Arrow diagramming method)

Porém, na quarta edição do PMBOK (2008), consta uma alteração no capítulo relativo a Gerenciamento de tempo do Projeto que passou a recomendar apenas o Método MDP, salientando o seguinte:

Com o uso do desenvolvimento de cronogramas auxiliado por computador, o Método do Diagrama de Setas (MDS) é raramente utilizado. (PMBOK, 2008, p.288)

Nos softwares MS-Project (2007) e Primavera (versão P6), ferramentas mais difundidas atualmente para montagem de cronogramas de acompanhamento, 0 método utilizado é MDP - Método do Diagrama de Precedência.

Portanto, será apresentado, neste trabalho, apenas o método MDP, que consiste, basicamente, na representação por caixas unidas entre si por setas que representam a ligação entre as atividades.

Tomando-se como exemplo a etapa de estrutura, tem-se as seguintes atividades principais:

- Fôrma

- Armação

- Concretagem

- Desenforma 
Essas atividades, unidas pelo diagrama de precedência, poderiam ser representadas conforme a Figura 8.

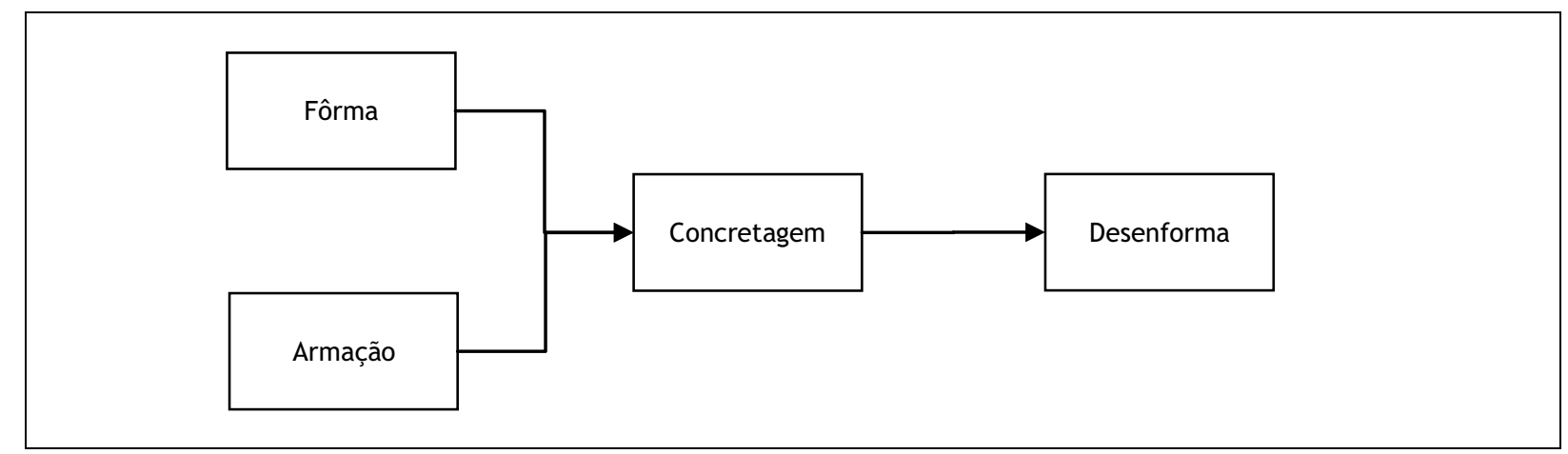

Figura 8 - Exemplo de atividades ligadas pelo método do diagrama de precedência

As atividades de fôrma e armação poderiam ser iniciadas juntamente e necessariamente terminar juntas, já que para o início da atividade de concretagem é necessário que ambas estejam concluídas. Portanto, entende-se que fôrma e armação são predecessoras da atividade de concretagem que, por sua vez, é predecessora da desenforma.

As setas que ligam as atividades umas às outras, devido à interdependência, podem ser chamadas de "ligações" (MATTOS, 2010) ou de “vínculos” conforme explanado por Bernardes (2010). Caracterizam-se, segundo o MS-Project, de acordo com o tipo de dependência entre as tarefas, conforme quadro 9. 


\begin{tabular}{|c|c|c|}
\hline $\begin{array}{c}\text { TIPO DE } \\
\text { VÍNCULO }\end{array}$ & DESCRIÇÃO & EXEMPLO \\
\hline TI & Término-a-Início & $\begin{array}{l}\text { Concretagem } \\
\text { A desenforma inicia-se após o término da } \\
\text { concretagem }\end{array}$ \\
\hline TT & Término-a-Término & $\begin{array}{l}\text { Armação } \\
\text { As tarefas de fôrma e armação devem } \\
\text { terminar juntas }\end{array}$ \\
\hline II & Início-a-Início & $\begin{array}{l}\text { Armação } \\
\text { As talocação de } \\
\text { embutidos na laje } \\
\text { embutidos na laje devem iniciar juntas }\end{array}$ \\
\hline IT & Início-a-Término & $\begin{array}{l}\text { A protensão dos cabos inicia-se após o } \\
\text { término da concretagem }\end{array}$ \\
\hline
\end{tabular}

Quadro 9 - Tipos de vínculo entre tarefas (Adaptação de BERNARDES, 2010) 


\title{
d. Linha de Base
}

Linha de base ou baseline é definida, no artigo "Organizando Processos de Requisitos" de Fiorini et al. (2010), como o conjunto de informações que servirão de referência para controlar as atividades do projeto.

Os autores ainda complementam que, uma vez estabelecida uma baseline, a alteração das informações (valores previstos como: datas início, datas de término, custo, receita, avanço físico e etc.) só pode ser realizada via procedimento formal. Assim, a partir do momento em que alguns requisitos forem definidos, pode-se estabelecer uma baseline e, dessa forma, tem-se um controle maior sobre as alterações ocorridas nas diversas versões.

O PMBOK (2008), em seu glossário, define linha de base ou baseline, da seguinte forma:

\begin{abstract}
Um plano aprovado para um projeto, somadas ou subtraídas as mudanças aprovadas. Ela é comparada com o desempenho real para determinar se o desempenho está dentro dos limites de variação aceitáveis. Em geral, refere-se à linha de base atual, mas pode se referir à original ou a alguma outra linha de base. Normalmente usada com um atributo modificador (por exemplo, linha de base de desempenho dos custos, do cronograma, da medição de desempenho, da técnica). (PMBOK, 2008, p.297)
\end{abstract}

Já, o manual do software Microsoft Project (2007) define linha de base como os pontos de referência do projeto, a partir do qual se compara o andamento do projeto real. Ressalta, ainda, que a linha de base deve incluir as melhores estimativas para a duração de tarefas, as datas de início e de término, os custos e outras variáveis do projeto que serão monitorados.

Com base nas definições acima, pode-se entender por linha de base o conjunto de dados essenciais para o acompanhamento da obra. Tais dados serão gerados por meio do planejamento detalhado e podem ser relacionados da seguinte forma:

- Etapas, atividades e serviços previstos para a execução da obra (EAP Estrutura Analítica de Projeto); 
- Datas de início e término dos serviços e consequentemente das Atividades e Etapas;

- Custo previsto;

- Receita prevista;

- Recursos ou insumos previstos para cada serviço.

As informações da linha de base servirão de referência no acompanhamento da obra, podendo indicar, por exemplo, atrasos no andamento das atividades da obra.

No sistema de gestão é imprescindível que seja possível a visualização da linha de base do projeto e a variação entre o estimado e o real.

\section{e. Gráfico de Gantt}

No início do século XX, Henry Gantt, em seus estudos sobre construção naval e o suprimentos de armamento, durante a Primeira Guerra Mundial, introduziu diagramas e gráficos para controle das atividades. Esses gráficos são hoje conhecidos como Gráfico de Gantt e são utilizados praticamente sem nenhuma alteração em relação aos originais (OLIVEIRA, 2003).

Também conhecido como Gráfico de barras, é definido de acordo com o PMBOK (2008) como uma representação gráfica de informações relacionadas ao cronograma.

Segundo Almeida (2006), Henry L. Gantt introduziu o cronograma de barras como ferramenta de controle de produção de atividades e sendo uma das ferramentas mais difundidas mundialmente. As barras horizontais representam as durações das atividades. Quanto maior a barra, maior será a duração de uma tarefa. As divisões verticais representam as unidades de tempo, conforme Figura 9. 
Almeida (2006) salienta ainda que, no cronograma de barras, é notável a excelente comunicação visual proporcionada e é justamente essa a razão de seu uso generalizado, não apenas na construção leve, como também em obras pesadas como construção e montagem de plataformas, por exemplo.

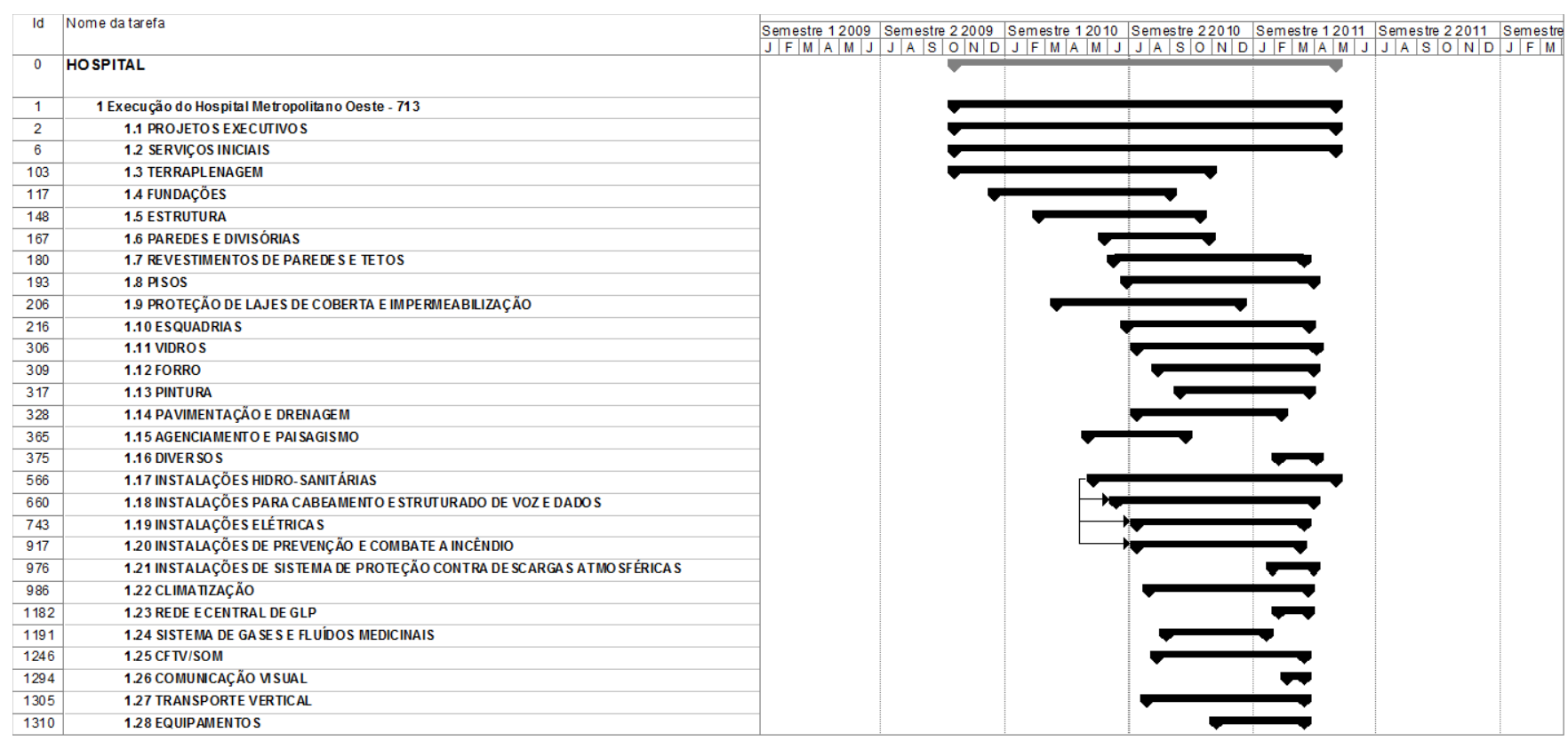

Figura 9 - Exemplo de gráfico de Gantt (Fonte: gráfico elaborado no MS-Project 2007)

\section{f. Cronograma do Projeto}

O PMBOK (2008) define cronograma do projeto como o conjunto de elementos organizados de forma a possibilitar análises do planejamento e, posteriormente, do acompanhamento do projeto.

Mattos (2010) define que o cronograma que resulta do planejamento é o produto de um método bem definido, e não um conjunto de barras desenhadas a esmo. Complementa, ressaltando que o cronograma, é por excelência, o instrumento do planejamento no dia-a-dia da obra e é com base nele que o gerente e sua equipe devem tomar algumas providências, conforme relacionado no quadro 10. 


\begin{tabular}{|l|}
\hline Providências a serem tomadas com base no cronograma da obra \\
\hline Programar as atividades da equipe de campo \\
\hline Instruir as equipes \\
\hline Fazer pedidos de compras \\
\hline Alugar equipamentos \\
\hline Recrutar operários \\
\hline Aferir o progresso das atividades \\
\hline Monitorar atrasos e adiantamentos nas atividades \\
\hline Replanejar a obra \\
\hline Pautar reuniões \\
\hline
\end{tabular}

Quadro 10- Relação das providências a serem tomadas com base no cronograma (MATTOS, 2010)

\subsubsection{Planejamento econômico-financeiro}

Mattos (2006) ressalta que independentemente da localização, recursos, prazo, cliente e tipo de projeto, uma obra é eminentemente uma atividade econômica e, como tal, o aspecto custo reveste-se de especial importância e após definido o custo e o percentual de lucro almejado, o preço de venda da obra ou receita prevista também é relevante no planejamento econômico-financeiro.

Entretanto, com este trabalho não se propõe definir práticas e conceitos para definição do preço de custo e venda, mas apenas ressaltar a importância desses na gestão de contratos. 
Silva (1999), definindo os tipos de orçamento de obras, também os separa em dois tipos:

Orçamento de custo: quanto deverá ser desembolsado para a obra ocorrer Orçamento de venda: trata-se do orçamento de custo, acrescidos do lucro

Assim, serão tratados, a seguir, os pontos essenciais do planejamento econômicofinanceiro, no que se refere aos seguintes tópicos:
a. Custo
b. Receita
c. Distribuição do custo e receita ao longo da duração do projeto

\section{a. Custo}

O custo da obra precede a etapa de orçamentação e deve envolver a identificação, descrição, quantificação, análise e valorização de uma série de itens (MATTOS, 2006) que comporão o custo previsto da obra.

Mattos (2006) salienta que o orçamento, por basear-se em previsões, é uma estimativa aproximada. Portanto, o custo orçado não tem que ser exato, porém preciso.

Silva (1999) separa o orçamento em fases, conforme Figura 10.

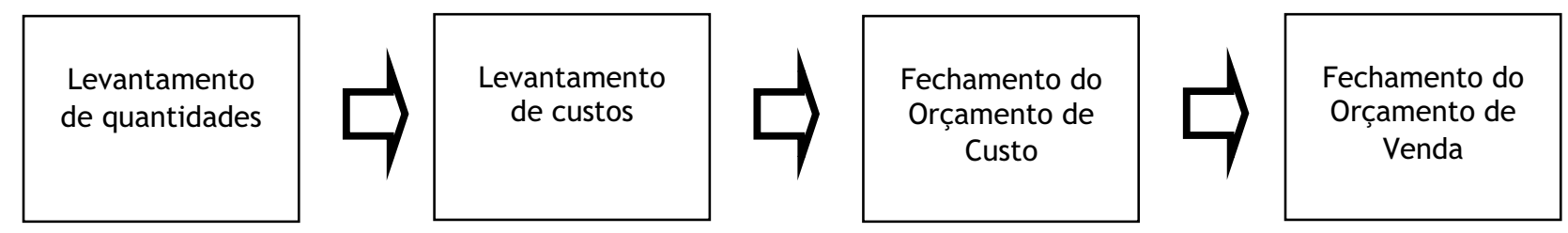

Figura 10 - Etapas do orçamento (SILVA, 1999) 
Com isso, entende-se que o custo previsto da obra é resultado de um processo de orçamentação, composto pelo levantamento das quantidades do projeto e levantamento de custos unitários.

Silva (1999) exemplifica o levantamento de quantidades para execução de um muro de blocos de concreto, conforme Tabela 1.

Tabela 1 - Exemplo de levantamento de quantidades

\begin{tabular}{lcc}
\hline \multicolumn{1}{c}{ DESCRIÇÃo } & UNIDADE & $\begin{array}{c}\text { QUANTIDADE } \\
\text { PREVISTA }\end{array}$ \\
\hline Bloco de Concreto & un & 23,0556 \\
\hline Tábua de Cambará & $\mathrm{m}^{3}$ & 0,0102 \\
\hline Pontalete de Cambará & $\mathrm{m}^{3}$ & 0,0038 \\
\hline Sarrafo de Cambará & $\mathrm{m} 3$ & 0,0013 \\
\hline Cimento & $\mathrm{kg}$ & 36,11 \\
\hline Aço CA-50 5/16" & $\mathrm{kg}$ & 3,3333 \\
\hline Aço CA-50 1/4" & $\mathrm{kg}$ & 2,8889 \\
\hline Cal & $\mathrm{kg}$ & 3,556 \\
\hline Areia & $\mathrm{m}^{3}$ & 0,0889 \\
\hline Pedra 2 & $\mathrm{m}^{3}$ & 0,0667 \\
\hline Arame Recozido & $\mathrm{kg}$ & 0,1222 \\
\hline Betoneira & $\mathrm{h}$ & 0,7333 \\
\hline Oficial & $\mathrm{h}$ & 1,875 \\
\hline Servente & $\mathrm{h}$ & 2,1 \\
\hline
\end{tabular}

Com base nas quantidades, é necessário fazer-se a valorização dos itens levantados que, conforme Silva (1999), pode ocorrer de três formas:

$1^{\text {a }}$ Consulta aos fornecedores de materiais e/ou serviços e associação de custos com preço fechado;

$2^{a}$ Utilização de preços de banco de dados da empresa;

$3^{a}$ Criação de composições unitárias. 
As composições unitárias, segundo (MATTOS, 2006), contêm os insumos do serviço com seus respectivos índices (quantidade de cada insumo requerida para realização de uma unidade do serviço) e valor (proveniente da cotação de preços e da aplicação dos encargos sobre a hora-base do trabalhador). Na Tabela 2, estão relacionados os itens que fazem parte da composição unitária do serviço de concretagem.

Tabela 2 - Exemplo de composição unitária (TCPO, 2008)

\begin{tabular}{|l|r|r|r|r|}
\hline \multicolumn{1}{|l|}{$\begin{array}{l}\text { CONCRETAGEM incluindo lançamento, adensamento e } \\
\text { acabamento do concreto em fundação }\end{array}$} & $\mathbf{m}^{\mathbf{3}}$ \\
\hline \multicolumn{1}{|c|}{ Descrição } & Unidade & $\begin{array}{c}\text { Coeficiente } \\
\text { unitário } \\
(\mathbf{Q u a n t . ~ p o r ~} \\
\left.\mathbf{m}^{3}\right)\end{array}$ & $\begin{array}{c}\text { Custo } \\
\text { unitário } \\
\mathbf{( R \$ )}\end{array}$ & $\begin{array}{r}\text { Custo } \\
\text { Total } \\
\text { (R\$) }\end{array}$ \\
\hline Pedreiro & $\mathrm{H}$ & 2,000000 & 5,42 & 24,57 \\
\hline Servente & $\mathrm{H}$ & 6,000000 & 4,54 & 61,75 \\
\hline $\begin{array}{l}\text { Concreto 25 MPa, inclusive } \\
\text { bombeamento }\end{array}$ & $\mathrm{m}$ & 1,020000 & 298,9 & 304,88 \\
\hline $\begin{array}{l}\text { VIBRADOR de imersão, elétrico, } \\
\text { potência 2 HP (1,5 kW) - vida útil } \\
4.500 \mathrm{~h}\end{array}$ & HPROD & 0,100000 & 3,88 & 0,39 \\
\hline
\end{tabular}

O custo ainda pode ser dividido em diretos e indiretos, conforme definido, a seguir, por Mattos (2006):

- Custos diretos: são aqueles diretamente associados aos serviços de campo.

- Custos indiretos: são aqueles que não estão diretamente associados ao serviços de campo em si, mas que são requeridos para que eles possam ser feitos (exemplo: locação de veículos, equipamentos de apoio, viagens, estadias, administração central, etc.).

O PMBOK (2008) recomenda que as estimativas de custos sejam agregadas por pacotes de trabalho, de acordo com a EAP, de forma que possam ser agregadas 
para os níveis de componentes mais altos da EAP, como contas de controle, e enfim, para o projeto todo.

Na Tabela 3, são apresentados os custos orçados para as etapas do projeto, conforme EAP definida previamente.

Tabela 3 - Exemplo de custo por etapa do projeto

\begin{tabular}{|c|c|}
\hline DESCRIÇÃO DAS ETAPAS & ORÇAMENTO DE CUSTO \\
\hline Custos diretos & $24.352 .180,08$ \\
\hline Projetos executivos & $421.733,08$ \\
\hline Serviços iniciais e instalações provisórias & $155.030,07$ \\
\hline Terraplenagem & $810.505,00$ \\
\hline Fundações & $1.878 .488,65$ \\
\hline Estrutura & $3.719 .479,80$ \\
\hline Paredes e divisórias & $566.115,14$ \\
\hline Revestimentos de paredes e tetos & $1.225 .628,19$ \\
\hline Pisos & $849.864,72$ \\
\hline Proteção de lajes de coberta e impermeabilização & $523.365,17$ \\
\hline Esquadrias & $1.566 .752,88$ \\
\hline Vidros & $48.991,66$ \\
\hline Forro & $289.535,86$ \\
\hline Pintura & $277.243,28$ \\
\hline Pavimentação e drenagem & $771.054,24$ \\
\hline Agenciamento e paisagismo & $335.371,99$ \\
\hline Diversos & $560.381,15$ \\
\hline Instalações hidrossanitárias & $1.034 .007,03$ \\
\hline Instalações para cabeamento estruturado de voz e dados & $603.266,21$ \\
\hline Instalações elétricas & $1.994 .069,60$ \\
\hline Instalações de prevenção e combate a incêndio & $282.214,45$ \\
\hline Instalações de sistema de proteção contra descargas atmosféricas & $34.418,51$ \\
\hline Climatização & $3.317 .977,64$ \\
\hline Rede e central de glp & $8.351,70$ \\
\hline Sistema de gases e fluídos medicinais & $510.247,79$ \\
\hline CFTV/som & $605.627,75$ \\
\hline Comunicação visual & $22.688,38$ \\
\hline
\end{tabular}




\begin{tabular}{|c|c|}
\hline Transporte vertical & $1.080 .000,00$ \\
\hline Equipamentos & $859.770,14$ \\
\hline Custos indiretos & $2.296 .432,67$ \\
\hline Seguros & $82.666,67$ \\
\hline Água/luz/gás & $52.880,00$ \\
\hline Telefone / celular / rádio & $33.760,00$ \\
\hline Material escritório/expediente & $43.651,00$ \\
\hline Refeição & $47.045,00$ \\
\hline Condução/locomoção/vale transp. & $30.250,00$ \\
\hline Aluguéis e condomínio & $19.200,00$ \\
\hline Viagens e estadias & $168.000,00$ \\
\hline Mão-de-obra indireta & $847.767,00$ \\
\hline EPI / EPC & $39.000,00$ \\
\hline Ferramenta & $78.634,00$ \\
\hline Combust. /lubrific. veículos & $10.380,00$ \\
\hline Combust. / lubrificantes equip. & $26.675,70$ \\
\hline Locação veículos & $55.360,00$ \\
\hline Manutenção veículos & $3.460,00$ \\
\hline Equip. apoio & $270.081,30$ \\
\hline Segurança canteiro & $158.400,00$ \\
\hline Informatica & $12.000,00$ \\
\hline Mobiliário do canteiro & $65.622,00$ \\
\hline Ligações provisórias & $80.000,00$ \\
\hline Topografia & $126.000,00$ \\
\hline Controle tecnológico & $45.600,00$ \\
\hline TOTAL (R\$) & $26.648 .612,75$ \\
\hline
\end{tabular}

Os custos ainda podem ser visualizados no projeto sobre três aspectos diferentes:

Custo planejado ou orçado: é elaborado conforme orçamento de custos dos serviços da obra, geralmente elaborado pela área de orçamento.

Custo comprometido: trata-se do custo que ainda não foi efetivado (o processo de compras está fechado), ou seja, o pedido/contrato foi efetuado e, portanto, já se sabe o valor a ser gasto. 
Custo realizado ou incorrido: a partir do momento em que a nota fiscal é registrada/contabilizada, o custo deixa de ser "comprometido" e passa a ser "realizado" ou "incorrido" sob o aspecto contábil. (SANTIN DE SOUZA, 2006). ${ }^{24}$

$\mathrm{Na}$ figura Figura 11, são conceituados os tipos de custos que são utilizados para tomada de decisão no projeto.

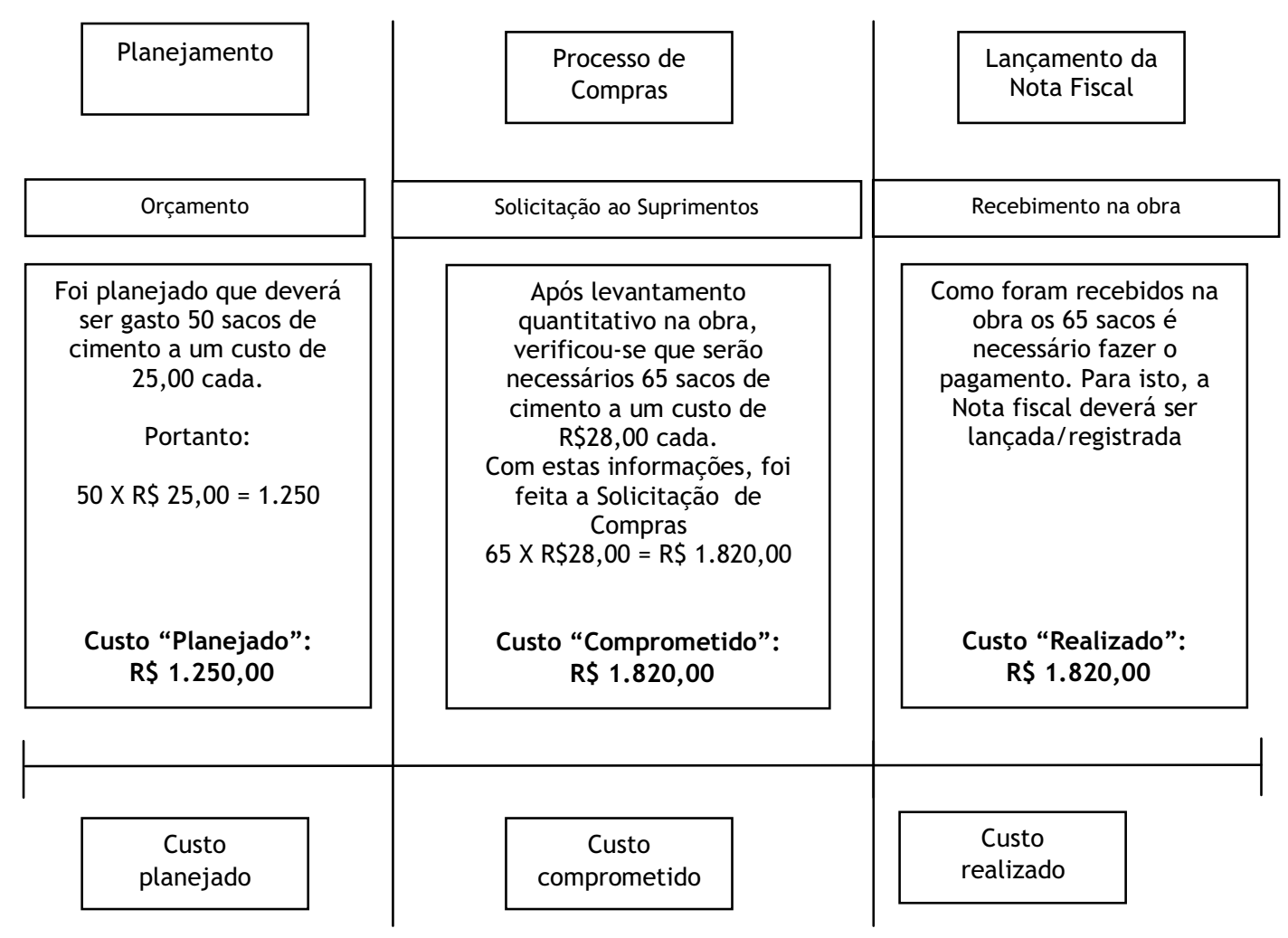

Figura 11 - Conceituação de custos planejados, comprometidos e incorrido

${ }^{24}$ Contabilmente, há ainda o reconhecimento do custo incorrido através do método de percentual de acabamento, ou seja, custo realizado do empreendimento proporcional ao progresso físico da obra (CAVALCANTE et al., 2010). 


\section{b. Receita}

Da mesma forma que o custo precede da orçamentação, a receita ou preço de venda precede do custo da obra, da identificação dos impostos e taxas e da definição do lucro final almejado (MATTOS, 2006).

Ainda, com relação ao valor de venda, cabe comentar sobre o BDI - Benefício e Despesas Indiretas ou LDI - Lucro e Despesas Indiretas.

Cardoso (2009) informa que, em termos práticos, o BDI é o percentual que deve ser aplicado sobre o custo direto dos itens da planilha da obra para se chegar ao preço de venda. Nesse caso, entende-se que os custos indiretos, ou seja, despesas com viagens, estadias, locação de veículos, etc., não foram orçados, sendo aplicado percentual sobre os custos diretos da obra.

Porém, há várias discussões sobre o assunto e especialistas, como Tisaka (2008) e Silva (2008), possuem definições que detalham as formas de cálculo do BDI e todos concordam que não é admissível que a construtora adote um único BDI para todas as obras.

\section{c. Distribuição dos valores de custo e receita ao longo do projeto}

O custo e a receita de cada etapa do projeto deverão ser distribuídos ao longo do tempo, conforme duração das atividades, de forma que se possa avaliar o custo previsto mensal e a receita prevista mensal.

A distribuição mais conhecida é a normal, apresentada por Abraham de Moivre em 1.733 e seu resultado foi ampliado por Laplace na Teoria das Analítica das Probabilidades em 1.812 em análises de erros. Já Gauss a utilizava em análise de dados astronômicos e posteriormente a "Curva de distribuição normal” passou a ser conhecida como “Curva de Gauss”. Em 1.972, Esprit Joufret a apelidou de “Curva Sino”, como é conhecida popularmente nos dias atuais (UPC, 2010). 
A curva de Gauss que, segundo Silva (1997), é estatística percentual em função de um período determinado que, quando aplicada a um montante, pode trazer uma previsão do fluxo de sua formação, conforme Gráfico 1. Silva (1997) ressalta ainda, que:

[...] empreendimentos como os de construção civil quando bem planejados e executados originam desembolsos que tendem a se aproximar da curva de Gauss. (SILVA, 1977)

\section{Correlação de Custos Programados}

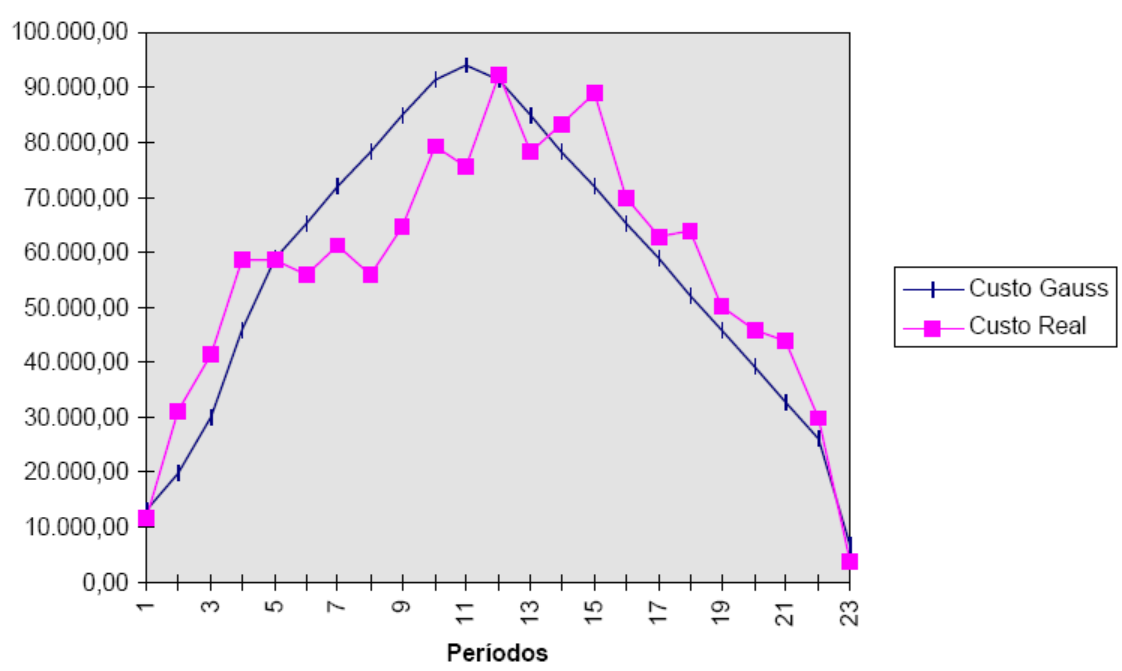

Gráfico 1 - Distribuições do custo baseado na curva de Gauss e pela programação final (Fonte: Silva,1997)

No quadro 11, o exemplo de cálculo da distribuição da curva sino feito por meio do MS-Project, 2007.

\begin{tabular}{|c|c|c|c|c|c|c|c|c|c|}
\hline \multicolumn{2}{|c|}{ Sino } \\
\hline $1^{\circ} \mathrm{dia}$ & $2^{\circ} \mathrm{dia}$ & $3^{\circ} \mathrm{dia}$ & $4^{\circ} \mathrm{dia}$ & $5^{\circ} \mathrm{dia}$ & $6^{\circ} \mathrm{dia}$ & $7^{\circ} \mathrm{dia}$ & $8^{\circ} \mathrm{dia}$ & $9^{\circ} \mathrm{dia}$ & $10^{\circ} \mathrm{dia}$ \\
\hline 2 & 4 & 8 & 16 & 20 & 20 & 16 & 8 & 4 & 2 \\
\hline
\end{tabular}

(Valores em milhões de Reais)

Quadro 11 - Exemplo de distribuição sino baseada no cálculo do MS-Project (2007) 


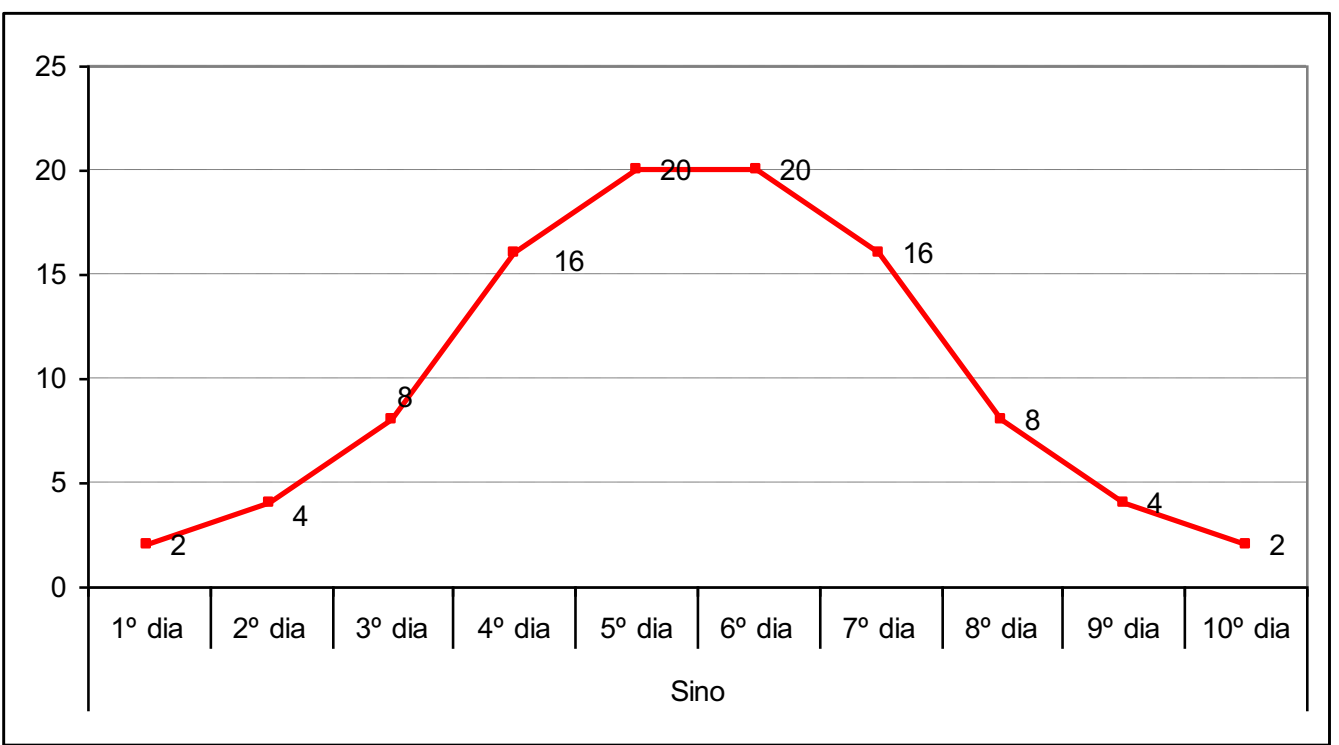

(Valores em milhões de Reais)

Gráfico 2 - Exemplo de distribuição sino baseada no cálculo do MS-Project (2007)

Embora a curva de Gauss seja a mais recomendada para projetos de construção civil, há outras variações de curvas de distribuição que podem ser consideradas.

A forma mais simples de se destinar os custos e receitas ao longo dos meses é por meio da distribuição linear ou uniforme, de maneira que os valores sejam distribuídos igualmente conforme os dias previstos para realização da atividade.

Portanto, a distribuição do valor de R\$100 milhões para uma atividade com 5 dias de duração seria conforme quadro 12.

\begin{tabular}{|c|c|c|c|c|}
\hline \multicolumn{5}{|c|}{ Curva uniforme } \\
\hline $1^{\circ}$ dia & $2^{\circ}$ dia & $3^{\circ}$ dia & $4^{\circ}$ dia & $5^{\circ}$ dia \\
\hline 20 & 20 & 20 & 20 & 20 \\
\hline
\end{tabular}

(Valores em milhões de Reais)

Quadro 12 - Exemplo de distribuição uniforme baseada no cálculo do MS-Project (2007) 
A distribuição poderia ser visualizada de acordo com o Gráfico 3.

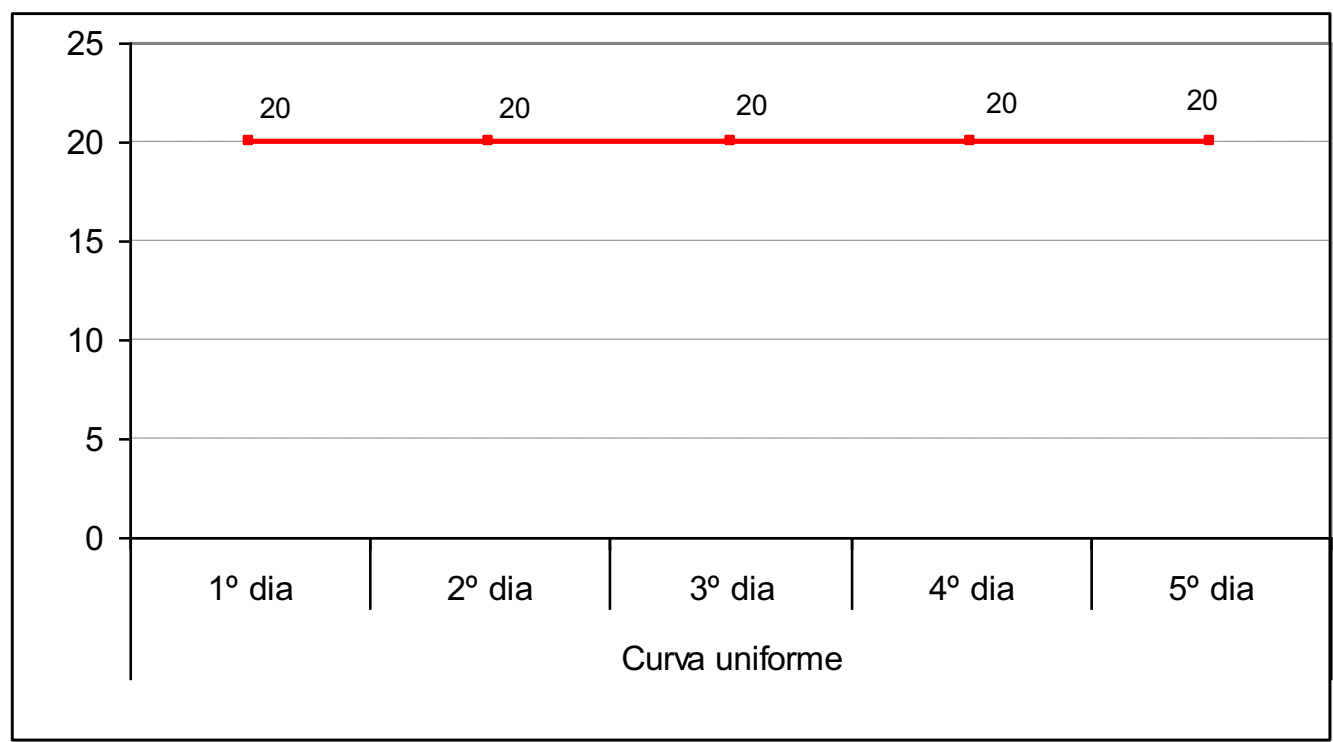

(Valores em milhões de Reais)

Gráfico 3 - Exemplo de distribuição uniforme baseada no cálculo do MS-Project (2007)

Além das distribuições citadas, outras também podem ser utilizadas. No MSproject (2007), são denominadas de “delimitações” e caracterizam-se pela forma como um trabalho agendado para uma atribuição será distribuído ao longo do tempo. As delimitações utilizadas pelo MS-Project são:

- Crescente

- Decrescente

- Pico duplo

- Pico inicial (curva beta ${ }^{25}$ )

- Pico final (curva beta)

- Curva Gauss (denominada no MS-Project como “Tartaruga”)

As informações de custo e receita distribuídas no tempo são de suma importância, já que ao longo da execução do projeto, os valores reais deverão ser registrados e

${ }^{25}$ A distribuição do tipo "beta” pode ser estatisticamente conceituado: assimétrica distorcida para a direita ou assimétrica distorcida para esquerda (MATTOS,2010). 
comparados com os originalmente planejados (ALMEIDA, 2006). Por isso são importantes se visualizados na ferramenta de forma dinâmica.

\subsection{Controle do projeto}

Neste tópico, será realizada uma abordagem quanto ao monitoramento e controle do projeto, sendo focado o controle físico e financeiro do contrato.

\subsubsection{Controle físico}

\section{a. Avanço físico das tarefas}

Em seu artigo sobre “Informatização do Planejamento e Controle de Produção", Akkari et al. (2003) orientam sobre a utilização do MS-Project para indicar o avanço físico da Obra:

[...] ]ao gerar o plano de longo prazo no software MS-Project, é necessário lançar o número de homens-hora para cada atividade, de forma a calcular a sua duração. $O$ avanço físico é calculado automaticamente pelo software através da formula abaixo. À medida que as atividades são controladas e o plano é atualizado, este indicador é recalculado. 0 objetivo deste indicador é apontar o avanço físico da obra em determinado período de tempo. (AKKARI et al., 2003, p. 7).

Esse índice é dado conforme a Fórmula 1.

Percentual concluído $=\frac{\mathrm{N}^{\circ} \text { de horas de mão-de-obra gastas na semana }}{\mathrm{N}^{\circ} \text { de horas de mão-de-obra total do projeto }}$

Fórmula 1 - Percentual concluído por horas (AKKARI, 2003) 
O MS-project (2007) define como \% físico concluído o valor percentual concluído da tarefa e exemplifica da seguinte forma o critério de cálculo:

[...] Um projeto de construção de um muro de pedra consiste em 100 pedras erguidas em cinco fileiras. A primeira fileira de 20 pedras pode ser erguida em 20 minutos, mas a segunda fileira leva 25 minutos porque agora é preciso erguer as pedras uma fileira acima, portanto demora um pouco mais. A terceira fileira levaria 30 minutos; a quarta, 35 minutos, $e$ a última fileira levaria 40 minutos para ser erguida, totalizando 150 minutos. Após erguer as três primeiras fileiras, poderia-se dizer que o projeto está $60 \%$ concluído fisicamente (60 pedras erguidas de um total de 100). No entanto, você gastou 75 dos 150 minutos; portanto, em termos de duração, o trabalho está apenas 50\% concluído. (MS-PROJECT, 2007)

O MS-Project (2007) ainda orienta que, dependendo da forma do trabalho, ou ainda a forma que se ganha pelo trabalho (por pedra ou por hora), pode-se escolher o valor de porcentagem concluída ou o valor de porcentagem física concluída a fim de que isso seja adequadamente refletido no controle do projeto.

Portanto, o MS-Project (2007) fornece as duas formas de cálculo para o avanço físico.

A primeira delas é a mesma apresentada na Fórmula 1 e a segunda seria:

$$
\text { Avanço Físico \% }=\quad \begin{gathered}
\text { quantidade de elementos }\left(^{*}\right) \text { executados } \\
\text { quantidade de elementos }\left(^{*}\right) \text { total planejados }
\end{gathered}
$$

(*) exemplo: pedras

Fórmula 2 - Percentual de avanço físico por quantidade

Para o avanço físico dos serviços é necessário definir-se os critérios de medição dos progressos físicos parciais das atividades, ou seja, qual a unidade de medida dos elementos planejados e executados.

Uma atividade importante, segundo Almeida (2006), é o controle da apropriação e medição, que consiste no acompanhamento de cada atividade constante na EAP. 
As informações da apropriação são essenciais para os controles da produção e de custos, atualização de cronogramas, elaboração de relatórios de progresso e reivindicações (ALMEIDA, 2006).

Alguns clientes de certo porte costumam adotar critérios próprios de medição, que a empresa contratada precisa conhecer e acompanhar da forma recomendada (ALMEIDA, 2006).

No quadro 13 são relacionadas algumas sugestões de critérios de medição, com base na pesquisa do autor. 


\begin{tabular}{|c|c|c|}
\hline $\begin{array}{c}\text { Atividade } \\
\text { (Pacote de trabalho) }\end{array}$ & Critérios de medição & $\begin{array}{l}\text { Unidade de } \\
\text { medição }\end{array}$ \\
\hline Alvenaria & $\begin{array}{l}\text { Para mão-de-obra, vãos com área inferior ou igual a } 2 \mathrm{~m}^{2} \text { devem } \\
\text { ser considerados como cheios. }\end{array}$ & Metro quadrado $\left(\mathrm{m}^{2}\right)$ \\
\hline Armação & $\begin{array}{l}\text { Geralmente a medição é executada após a completa colocação } \\
\text { nas fôrmas e liberação da frente de concretagem. } \\
\text { São considerados os comprimentos indicados nos projetos } \\
\text { executivos, não sendo usual considerar-se perdas e desbitolagens }\end{array}$ & Quilo (kg) \\
\hline Concretagem & $\begin{array}{l}\text { A medição usualmente é realizada após o seu lançamento nas } \\
\text { fôrmas liberadas para concretagem. O volume concretado é } \\
\text { medido pelas dimensões indicadas nos projetos executivos, não } \\
\text { sendo consideradas as perdas devido ao lançamento. }\end{array}$ & Metro cúbico $\left(\mathrm{m}^{3}\right)$ \\
\hline & Eletrodutos, eletrocalhas, fios e cabos & Metro (m) \\
\hline Elétrica & quadros elétricos, geradores, transformadores & Unidade (un) \\
\hline Emassamento & $\begin{array}{l}\text { Para mão-de-obra, vãos com área inferior ou igual a } 2 \mathrm{~m}^{2} \text { devem } \\
\text { ser considerados como cheios. }\end{array}$ & Metro quadrado $\left(\mathrm{m}^{2}\right)$ \\
\hline \multirow{2}{*}{$\begin{array}{l}\text { Escavação manual } \\
\text { ou mecânica }\end{array}$} & $\begin{array}{l}\text { Cavas e valas são medidas considerando-se uma folga de } 50 \mathrm{~cm} \\
\text { para cada lado entre a peça enterrada e as paredes da vala ou } \\
\text { cava }\end{array}$ & Metro cúbico $\left(\mathrm{m}^{3}\right)$ \\
\hline & $\begin{array}{l}\text { Valas para tubulação enterrada são medidas considerando-se uma } \\
\text { folga de } 25 \mathrm{~cm} \text { para cada lado entre o tubo e a parede da vala }\end{array}$ & Metro cúbico $\left(\mathrm{m}^{3}\right)$ \\
\hline $\begin{array}{l}\text { Estrutura metálica } \\
\text { (pré-fabricação e pré- } \\
\text { montagem) }\end{array}$ & $\begin{array}{l}\text { A conclusão das atividades, de fabricação até a pré-montagem, } \\
\text { possuem pesos, conforme abaixo } \\
\text { Fabricação : } 70 \% \\
\text { Pintura: } 20 \% \\
\text { Pré-montagem: } 10 \% \\
\text { (ALMEIDA, 2006) }\end{array}$ & Toneladas (t) \\
\hline Fôrmas & $\begin{array}{l}\text { Área de fôrmas igual a superfície de moldagem das peças a serem } \\
\text { concretadas, de acordo com a representação dessas peças no } \\
\text { desenho do projeto }\end{array}$ & Metro quadrado $\left(\mathrm{m}^{2}\right)$ \\
\hline \multirow{3}{*}{ Fundação } & Estaca pré-fabricada, estaca metálica & Metro cravado $(\mathrm{m})$ \\
\hline & Emenda de topo de estaca & Unidade (un) \\
\hline & Tubulão com diâmetro especificado no projeto & Metro $(\mathrm{m})$ \\
\hline \multirow[b]{2}{*}{ Instalações hidráulicas } & Tubulações & Metro (m) \\
\hline & Conexões e acessórios & Unidade (un) \\
\hline $\begin{array}{l}\text { Montagem de equipamentos } \\
\text { (eletromecânicos) }\end{array}$ & $\begin{array}{l}\text { Para as atividades de montagem considera-se as ponderações } \\
\text { abaixo: } \\
\text { Assentamento sobre bases: } 40 \% \\
\text { Alinhamento, nivelamento e grauteamento: } 30 \\
\text { Instalação de acessórios, escadas, plataformas: } 20 \% \\
\text { Testes e inspeção: } 10 \% \\
\text { (ALMEIDA, 2006) }\end{array}$ & Tonelada $(\mathrm{t})$ \\
\hline \multirow[b]{2}{*}{ Pintura } & Parede e piso & Metro quadrado $\left(\mathrm{m}^{2}\right)$ \\
\hline & Tubulações com diâmetro especificado em projeto & Metro (m) \\
\hline Revestimento de parede & Azulejo, revestimento cerâmico, pastilha, pedras diversas & Metro quadrado $\left(\mathrm{m}^{2}\right)$ \\
\hline
\end{tabular}

Quadro 13 - Critérios de medição (proposição da autora) 


\section{b. Ponderação do Projeto}

Assumpção e Rocha (1996) apresentam um modelo de planejamento e controle de empreendimentos, utilizando o peso ou representatividade do serviço em relação ao custo total da obra ou em relação ao total de horas da mão-de-obra.

No modelo apresentado, para cada serviço foram determinados os pesos (em custo e em homens-hora), caracterizando sua representatividade em relação aos totais desses parâmetros.

Assumpção e Rocha (1996) ainda ressaltam que alguns desses serviços possuem pouca representatividade em relação aos totais de custo ou de homens-hora necessários para executar a obra. Citam, como exemplo, os serviços de gabaritos e locação da obra, pintura do poço do elevador e montagem dos balancins, caracterizando-os como serviços de pouca representatividade, em custos ou em consumo de homens-hora, conforme Tabela 4. Porém, representam marcos importantes no desenvolvimento da obra, e devem estar contidos no modelo - o primeiro representa o início efetivo da obra; o segundo libera a montagem dos elevadores; e o terceiro marca o início da execução das fachadas. 
Tabela 4 - Ponderação do Projeto (ASSUMPÇÃO E ROCHA, 1996)

\begin{tabular}{|c|c|c|c|c|}
\hline \multirow{2}{*}{ ETAPAS E SERVIÇOS TESTEMUNHOS } & \multirow{2}{*}{$\begin{array}{c}\text { CUSTO } \\
\mathrm{R} \$\end{array}$} & \multicolumn{3}{|c|}{ HOMENS-HORA } \\
\hline & & $\%$ & $\mathrm{Hh}$ & $\%$ \\
\hline IMPLANTAÇÃO DO CANTEIRO & $31.682,00$ & 1,4350 & 3.176 & 1,0561 \\
\hline $\begin{array}{c}\text { SERVIÇOS PRELIMINARES } \\
\end{array}$ & $30.753,00$ & 1,3929 & 3.030 & 1,0076 \\
\hline GABARITOS E LOCAÇÃO DA OBRA & 929,00 & 0,0421 & 146 & 0,0486 \\
\hline INFRA-ESTRUTURA NA REGIÃO DA TORRE & $36.108,00$ & 1,6355 & 5.367 & 1,7847 \\
\hline FUNDAÇÕES DA TORRE & $15.134,00$ & 0,6855 & 2.093 & 0,6960 \\
\hline BLOCOS BALDRAMES DA TORRE & $16.670,00$ & 0,7551 & 2.665 & 0,8862 \\
\hline LAJE $1^{\circ}$ PISO DA TORRE & $4.304,00$ & 0,1949 & 609 & 0,2025 \\
\hline ESTRUTURAS NA REGIÃO DA TORRE & $428.219,00$ & 19,3959 & 64.533 & 21,4598 \\
\hline $\begin{array}{c}\text { ESTRUTURA DA TORRE ATÉ } 1^{\text {a }} \text { LAJE TIPO } \\
\end{array}$ & $53.461,00$ & 2,4215 & 8.729 & 2,9027 \\
\hline ESTRUTURA DA TORRE - TODAS AS LAJES TIPC & $345.616,00$ & 15,6544 & 51.480 & 17,1191 \\
\hline ESTRUTURA DA COBERTURA & $18.801,00$ & 0,8516 & 2.725 & 0,9062 \\
\hline ESTRUTURA CASA MÁQUINAS E CAIXA D'AGUA & $10.341,00$ & 0,4684 & 1.599 & 0,5317 \\
\hline OBRA BRUTA NA REGIÃO DA TORRE & $483.306,00$ & 21,8910 & 91.624 & 30,4686 \\
\hline ALVENARIA NA TORRE & $145.020,00$ & 6,5686 & 23.814 & 7,9191 \\
\hline ADUELAS, CONTRAMARCOS E EMBUTIDOS & $71.702,00$ & 3,2477 & 11.859 & 3,9436 \\
\hline CONTRAPISOS E IMPERMEABILIZAÇÃO DE RALC & $45.779,00$ & 2,0735 & 8.799 & 2,9260 \\
\hline REBOCO INTERNO & $160.554,00$ & 7,2722 & 39.044 & 12,9837 \\
\hline GESSO CORRIDO NO TETO & $23.947,00$ & 1,0847 & 4.399 & 1,4628 \\
\hline OBRAS NA CASA DE MÁQUINAS E COBERTURA & $35.670,00$ & 1,6156 & 3.553 & 1,1815 \\
\hline PINTURA DO POÇO PARA ELEVADORES & 634,00 & 0,0287 & 156 & 0,0519 \\
\hline OBRA FINA INTERNA NA TORRE & $671.881,00$ & 30,4324 & 60.137 & 19,9979 \\
\hline $\begin{array}{c}\text { ASSENTAMENTO DE AZULEJOS } \\
\end{array}$ & $78.011,00$ & 3,5335 & 9.624 & 3,2004 \\
\hline KITS HIDRÁULICOS ELÉTRICOS AÉREOS & $48.638,00$ & 2,2030 & 7.205 & 2,3959 \\
\hline PLACAS DO FORRO DE GESSO E MADEIRAS & $8.970,00$ & 0,4063 & 1.738 & 0,5780 \\
\hline ASSENTAMENTO DE PISOS CERÂMICOS & $39.598,00$ & 1,7936 & 4.135 & 1,3751 \\
\hline ENFIAÇÃO ELÉTRICA & $54.403,00$ & 2,4641 & 4.473 & 1,4874 \\
\hline APLICAÇÃO DE MASSA PVA & $27.190,00$ & 1,2316 & 4.721 & 1,5699 \\
\hline FOLHAS DE PORTAS & $86.214,00$ & 3,9050 & 6.620 & 2,2014 \\
\hline FOLHAS DE ESQUADRIAS E VIDROS & $82.415,00$ & 3,7329 & 2.470 & 0,8214 \\
\hline LOUÇAS E METAIS, INTERRUPTORES/TOMADAS & $112.034,00$ & 5,0745 & 4.923 & 1,6371 \\
\hline PINTURA FINAL INTERNA & $64.677,00$ & 2,9295 & 10.489 & 3,4880 \\
\hline $\begin{array}{c}\text { CARPETE E ASSOALHOS } \\
\end{array}$ & $69.731,00$ & 3,1584 & 3.739 & 1,2434 \\
\hline FACHADA & $118.121,00$ & 5,3502 & 21.858 & 7,2687 \\
\hline MONTAGEM DOS BALANCINS & $2.737,00$ & 0,1240 & 593 & 0,1972 \\
\hline FACHADA - REBOCO & $73.672,00$ & 3,3369 & 16.443 & 5,4679 \\
\hline ACAMENTO EM FACHADA & $41.712,00$ & 1,8893 & 4.822 & 1,6035 \\
\hline ELEVADORES & $81.383,00$ & 3,6862 & & 0,0000 \\
\hline MONTAGEM DOS ELEVADORES & $81.383,00$ & 3,6862 & & 0,0000 \\
\hline INFRA-ESTRUTURA DA PERIFERIA & $14.680,00$ & 0,6649 & 2.349 & 0,7811 \\
\hline $\begin{array}{l}\text { FUNDAÇÕES NA PERIFERIA } \\
\end{array}$ & $2.644,00$ & 0,1198 & 366 & 0,1217 \\
\hline BLOCOS E BALDRAMES NA PERIFERIA & $5.555,00$ & 0,2516 & 1.066 & 0,3545 \\
\hline LAJE $1^{\circ}$ PISO NA PERIFERIA & $6.481,00$ & 0,2936 & 917 & 0,3049 \\
\hline ESTRUTURAS NA PERIFERIA & $96.233,00$ & 4,3588 & 14.929 & 4,9645 \\
\hline ESTRUTURAS NA PERIFERIA & $75.514,00$ & 3,4204 & 11.488 & 3,8202 \\
\hline CONTENÇÃO DAS ESCAVAÇÕES & $20.719,00$ & 0,9385 & 3.441 & 1,1443 \\
\hline OBRA BRUTA NA PERIFERIA & $146.264,00$ & 6,6249 & 23.218 & 7,7209 \\
\hline ALVENARIA, REBOCO E INSTALAÇÕES & $87.723,00$ & 3,9734 & 13.695 & 4,5541 \\
\hline IMPERMEABILIZAÇÃO NA ÁREA DO TÉRREO & $58.541,00$ & 2,6516 & 9.523 & 3,1668 \\
\hline OBRA FINA NA PERIFERIA & $99.905,00$ & 4,5251 & 13.525 & 4,4976 \\
\hline ACABAMENTOS NO TÉRREO E PERIFERIA & $74.742,00$ & 3,3854 & 7.966 & 2,6490 \\
\hline EQUIPAMENTOS COMUNITÁRIOS & $19.560,00$ & 0,8860 & 4.037 & 1,3425 \\
\hline LIMPEZA FINAL DA OBRA & $5.603,00$ & 0,2538 & 1.522 & 0,5061 \\
\hline TOTAL & $2.207 .782,00$ & 100,0000 & 300.716 & 100,0000 \\
\hline
\end{tabular}

Fonte: ASSUMPÇÃO e ROCHA. Gerenciamento de Empreendimentos na Construção Civil: Modelo para Planejamento Estratégico da Produção de Edifícios, 1996. 
No MS-Project (2007), a representatividade utilizada para o cálculo do avanço físico é a duração. Portanto, tomando como base o cálculo do Ms-Project, pela duração e também as representatividades recomendadas por Assumpção e Rocha (1996), serão analisados, a seguir, os três tipos de representatividades.

Para tal, primeiramente, são exemplificados, na Figura 12, o cálculo das composições unitárias de algumas tarefas da atividade de fundações e o respectivo cálculo de duração (dias), Hh (homens-hora) e custo total (R\$). 


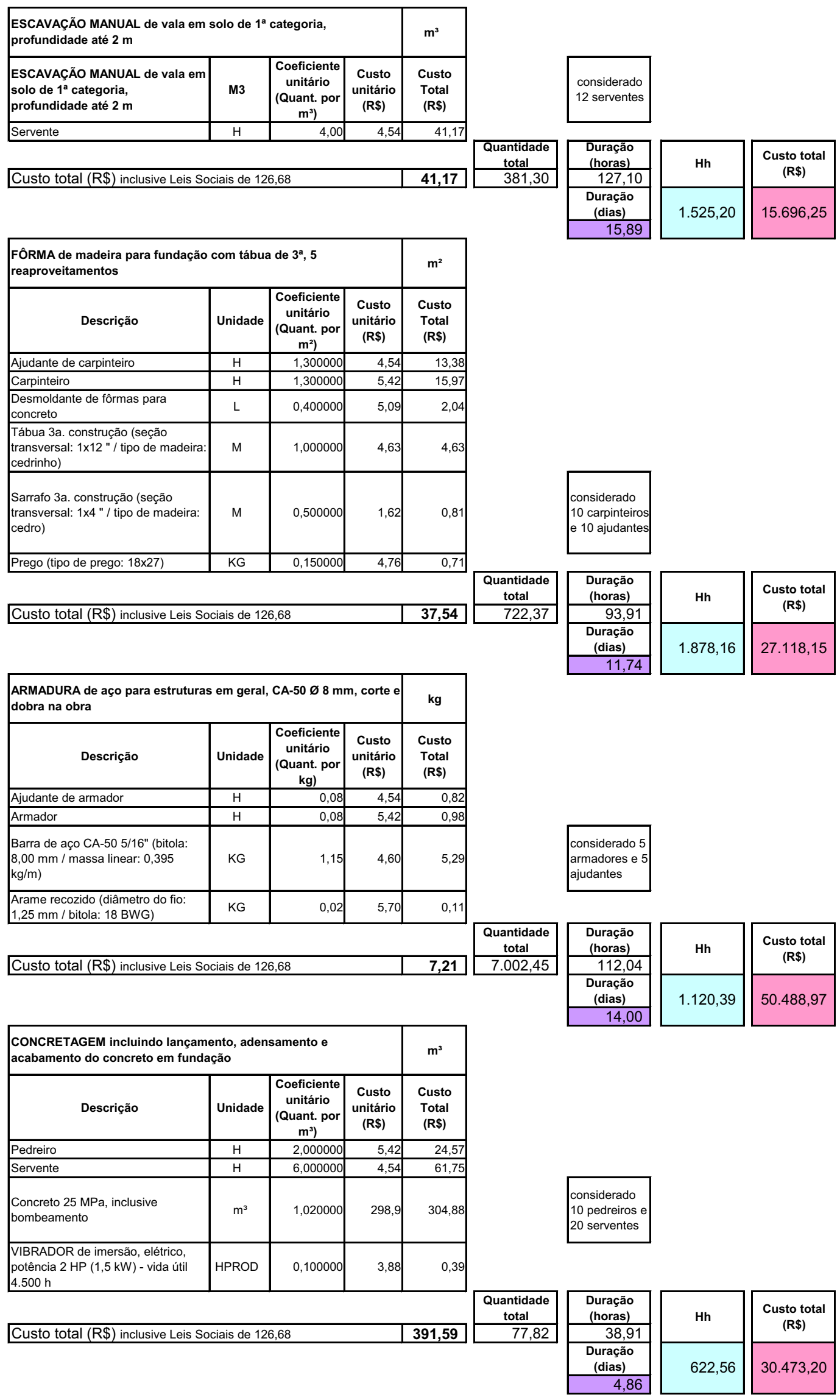

Fonte: Composições unitárias extraídas do Livro TCPO (2008)

Figura 12 - Adaptação das composições unitárias da etapa de fundações, exemplificando cálculo das durações, Hh e custo total 
Com base nas composições unitárias, exemplificadas na Figura 12 é possível calcular a representativade de cada tarefa, baseando-se na duração, Hh e Custo.

Percebe-se, dessa forma, uma variação considerável entre os três critérios de cálculo.

Tabela 5 - Exemplo de cálculo da representatividade pela duração

\begin{tabular}{lcccc}
\hline \multicolumn{5}{c}{ CÁLCULO DA REPRESENTATIVIDADE PELA DURAÇÃO } \\
\hline & & & Peso Atividade & Peso Projeto \\
\cline { 3 - 5 } & & Duração (dias) & $\begin{array}{c}\text { A = Quant. dias da Tarefa I } \\
\text { Quant. Dias total da Atividade }\end{array}$ & $\begin{array}{c}\text { B = Quant. dias da Tarefa I } \\
\text { Quant. Dias total do Projeto }\end{array}$ \\
\hline Projeto & Obra & $\mathbf{1 1 6}$ & & $\mathbf{1 , 0 0}$ \\
\hline Etapa & PROJETO & $\mathbf{7 0}$ & $\mathbf{1 , 0 0}$ & 0,21 \\
\hline Tarefa & Projeto de Fundações & 25 & 0,36 & 0,39 \\
\hline Tarefa & Projeto de Estrutura & 45 & 0,64 & 0,14 \\
\hline Etapa & FUNDAÇÕES & $\mathbf{4 6}$ & $\mathbf{1 , 0 0}$ & 0,10 \\
\hline Tarefa & Escavações & 16 & 0,34 & 0,12 \\
\hline Tarefa & Fôrma & 12 & 0,25 & 0,04 \\
\hline Tarefa & Armação & 14 & 0,30 & \\
\hline Tarefa & Concretagem & 5 & 0,10 & \\
\hline
\end{tabular}

Tabela 6 - Exemplo de cálculo da representatividade pelo Hh

\begin{tabular}{|c|c|c|c|c|}
\hline \multicolumn{5}{|c|}{ CÁLCULO DA REPRESENTATIVIDADE PELO Hh } \\
\hline & \multirow[b]{2}{*}{ EAP } & \multirow[b]{2}{*}{$\mathrm{Hh}(\mathrm{h})$} & Peso Atividade & Peso Projeto \\
\hline & & & $\begin{array}{c}\text { A = Custo da Tarefa / Custo total } \\
\text { da Atividade }\end{array}$ & $\begin{array}{c}\text { B = Custo da Tarefa / Custo total } \\
\text { do Projeto }\end{array}$ \\
\hline Projeto & Obra & $5.706,31$ & & 1,00 \\
\hline Etapa & PROJETO & 560,00 & 1,00 & \\
\hline Tarefa & Projeto de Fundações & 200,00 & 0,36 & 0,04 \\
\hline Tarefa & Projeto de Estrutura & 360,00 & 0,64 & 0,06 \\
\hline Etapa & FUNDAÇÕES & $5.146,31$ & 1,00 & \\
\hline Tarefa & Escavações & $1.525,20$ & 0,30 & 0,27 \\
\hline Tarefa & Fôrma & $1.878,16$ & 0,36 & 0,33 \\
\hline Tarefa & Armação & $1.120,39$ & 0,22 & 0,20 \\
\hline Tarefa & Concretagem & 622,56 & 0,12 & 0,11 \\
\hline
\end{tabular}


Tabela 7 - Exemplo de cálculo da representatividade pelo Custo

\begin{tabular}{|c|c|c|c|c|}
\hline \multicolumn{5}{|c|}{ CÁLCULO DA REPRESENTATIVIDADE PELO CUSTO } \\
\hline \multirow{2}{*}{\multicolumn{2}{|c|}{ EAP }} & \multirow[b]{2}{*}{ Custo (R\$) } & Peso Atividade & Peso Projeto \\
\hline & & & $\begin{array}{c}\text { A = Custo da Tarefa / Custo total } \\
\text { da Atividade }\end{array}$ & $\begin{array}{c}\text { B = Custo da Tarefa / Custo total } \\
\text { do Projeto }\end{array}$ \\
\hline Projeto & Obra & $160.776,57$ & & 1,00 \\
\hline Etapa & PROJETO & $37.000,00$ & 1,00 & \\
\hline Tarefa & Projeto de Fundações & $15.000,00$ & 0,41 & 0,09 \\
\hline Tarefa & Projeto de Estrutura & $22.000,00$ & 0,59 & 0,14 \\
\hline Etapa & FUNDAÇÕES & $123.776,57$ & 1,00 & \\
\hline Tarefa & Escavações & $15.696,25$ & 0,13 & 0,10 \\
\hline Tarefa & Fôrma & $27.118,15$ & 0,22 & 0,17 \\
\hline Tarefa & Armação & $50.488,97$ & 0,41 & 0,31 \\
\hline Tarefa & Concretagem & $30.473,20$ & 0,25 & 0,19 \\
\hline
\end{tabular}

Por exemplo, a tarefa de fôrma possui as seguintes representatividades, conforme demonstrado nas tabelas anteriores e consolidado na Tabela 8.

Tabela 8 - Exemplo de diferença entre representatividades da tarefa fôrma

\begin{tabular}{ccc}
\hline Tipo de representatividade/ponderação & Peso da Atividade & Peso do Projeto \\
\hline Duração & 0,25 & 0,10 \\
\hline Hh & 0,36 & 0,33 \\
\hline Custo & 0,22 & 0,17 \\
\hline
\end{tabular}

A representatividade ou o peso são utilizados para cálculo do avanço físico do projeto, portanto, é importante que se tenha definido qual o melhor critério a ser utilizado, pois as variações poderão ser consideráveis no projeto como um todo.

Porém, não se pretende, neste trabalho, definir qual o melhor tipo de representatividade a ser utilizada, mas ressaltar que isso deverá ser observado na gestão do projeto.

\section{c. Avanço físico do projeto}

Mattos (2010) ressalta ainda que a sequência executiva deve ser a preconizada no planejamento e as avaliações de avanço físico, nos respectivos períodos de medição, devem refletir fielmente e percentualmente o que está executado. 
Portanto, entende-se que o avanço físico da obra deve refletir fielmente o que está executado na obra.

Utilizando os pesos calculados no tópico anterior, pretende-se com as tabelas, a seguir, apresentar exemplos de cálculo utilizando os diferentes tipos de ponderação, que são: duração, Hh e custo.

Tabela 9 - Exemplo de cálculo do avanço físico utilizando a ponderação pela duração

\begin{tabular}{|c|c|c|c|c|c|c|c|}
\hline \multicolumn{8}{|c|}{ CÁLCULO DO AVANÇO FÍSICO UTILIZANDO A PONDERAÇÃO PELA DURAÇÃO } \\
\hline & \multirow{2}{*}{ EAP } & \multirow{2}{*}{$\begin{array}{c}\text { Duração } \\
\text { (dias) }\end{array}$} & Peso Atividade & Peso Projeto & $\begin{array}{l}\text { Avanço por } \\
\text { quantidade }\end{array}$ & $\begin{array}{c}\text { Avanço } \\
\text { ponderado } \\
\text { atividade }\end{array}$ & $\begin{array}{c}\text { Avanço } \\
\text { ponderado } \\
\text { projeto }\end{array}$ \\
\hline & & & $\begin{array}{c}\text { A = Quant. dias da Tarefa } \\
\text { / Quant. Dias total da } \\
\text { Atividade }\end{array}$ & $\begin{array}{c}\text { B = Quant. dias da Tarefa } \\
\text { / Quant. Dias total do } \\
\text { Projeto }\end{array}$ & c & $D=A \times C$ & $E=B \times C$ \\
\hline Projeto & Obra & 116 & & 1,00 & & & 20,31 \\
\hline Etapa & PROJETO & 70 & 1,00 & & & 27,86 & \\
\hline Tarefa & Projeto de Fundações & 25 & 0,36 & 0,21 & 60 & 21,43 & 12,88 \\
\hline Tarefa & Projeto de Estrutura & 45 & 0,64 & 0,39 & 10 & 6,43 & 3,86 \\
\hline $\begin{array}{l}\text { Etapa } \\
\end{array}$ & FUNDAÇÕES & 46 & 1,00 & & & 8,95 & \\
\hline Tarefa & Escavações & 16 & 0,34 & 0,14 & 10 & 3,42 & 1,36 \\
\hline Tarefa & Fôrma & 12 & 0,25 & 0,10 & 10 & 2,52 & 1,01 \\
\hline Tarefa & Armação & 14 & 0,30 & 0,12 & 10 & 3,01 & 1,20 \\
\hline $\begin{array}{l}\text { Tarefa } \\
\end{array}$ & Concretagem & 5 & 0,10 & 0,04 & & & \\
\hline
\end{tabular}

Tabela 10 - Exemplo de cálculo do avanço físico utilizando a ponderação pelo Hh

\begin{tabular}{|c|c|c|c|c|c|c|c|}
\hline \multicolumn{8}{|c|}{ CÁLCULO DO AVANÇO FÍSICO UTILIZANDO A PONDERAÇÃO PELO Hh } \\
\hline & \multirow{2}{*}{ EAP } & \multirow{2}{*}{$\begin{array}{l}\mathrm{Hh} \\
\text { (h) }\end{array}$} & Peso Atividade & Peso Projeto & $\begin{array}{l}\text { Avanço por } \\
\text { quantidade }\end{array}$ & $\begin{array}{c}\text { Avanço } \\
\text { ponderado } \\
\text { atividade }\end{array}$ & $\begin{array}{c}\text { Avanço } \\
\text { ponderado } \\
\text { projeto } \\
\end{array}$ \\
\hline & & & $\begin{array}{l}\text { A }=\text { Custo da Tarefa } / \\
\text { Custo total da Atividade }\end{array}$ & $\begin{array}{l}\mathrm{B}=\text { Custo da Tarefa / } \\
\text { Custo total do Projeto }\end{array}$ & c & $D=A \times C$ & $E=B \times C$ \\
\hline Projeto & Obra & $5.706,31$ & & 1,00 & & & 10,66 \\
\hline Etapa & PROJETO & 560,00 & 1,00 & & & 27,86 & \\
\hline Tarefa & Projeto de Fundações & 200,00 & 0,36 & 0,04 & 60 & 21,43 & 2,10 \\
\hline Tarefa & Projeto de Estrutura & 360,00 & 0,64 & 0,06 & 10 & 6,43 & 0,63 \\
\hline Etapa & FUNDAÇÕES & $5.146,31$ & 1,00 & & & 8,79 & \\
\hline $\begin{array}{c}\text { Tarefa } \\
\end{array}$ & Escavações & $1.525,20$ & 0,30 & 0,27 & 10 & 2,96 & 2,67 \\
\hline Tarefa & Fôrma & $1.878,16$ & 0,36 & 0,33 & 10 & 3,65 & 3,29 \\
\hline Tarefa & Armação & $1.120,39$ & 0,22 & 0,20 & 10 & 2,18 & 1,96 \\
\hline Tarefa & Concretagem & 622,56 & 0,12 & 0,11 & & & \\
\hline
\end{tabular}

Tabela 11 - Exemplo de cálculo do avanço físico utilizando a ponderação pelo custo

\begin{tabular}{|c|c|c|c|c|c|c|c|}
\hline \multicolumn{8}{|c|}{ CÁLCULO DO AVANÇO FíSICO UTILIZANDO A PONDERAÇÃO PELO CUSTO } \\
\hline & \multirow[t]{2}{*}{ EAP } & \multirow{2}{*}{$\begin{array}{c}\text { Custo } \\
\text { (R\$) }\end{array}$} & Peso Atividade & Peso Projeto & $\begin{array}{l}\text { Avanço por } \\
\text { quantidade }\end{array}$ & $\begin{array}{c}\text { Avanço } \\
\text { ponderado } \\
\text { atividade }\end{array}$ & $\begin{array}{c}\text { Avanço } \\
\text { ponderado } \\
\text { projeto } \\
\end{array}$ \\
\hline & & & $\begin{array}{l}A=\text { Custo da Tarefa } / \\
\text { Custo total da Atividade }\end{array}$ & $\begin{array}{l}\mathrm{B}=\text { Custo da Tarefa } / \\
\text { Custo total do Projeto }\end{array}$ & c & $D=A \times C$ & $E=B \times C$ \\
\hline Projeto & Obra & $160.776,57$ & & 1,00 & & & 12,77 \\
\hline Etapa & PROJETO & $37.000,00$ & 1,00 & & & 30,27 & \\
\hline Tarefa & Projeto de Fundações & $15.000,00$ & 0,41 & 0,09 & 60 & 24,32 & 5,60 \\
\hline Tarefa & Projeto de Estrutura & $22.000,00$ & 0,59 & 0,14 & 10 & 5,95 & 1,37 \\
\hline$\overline{E \text { Etapa }}$ & FUNDAÇÕES & $123.776,57$ & 1,00 & & & 7,54 & \\
\hline Tarefa & Escavações & $15.696,25$ & 0,13 & 0,10 & 10 & 1,27 & 0,98 \\
\hline Tarefa & Fôrma & $27.118,15$ & 0,22 & 0,17 & 10 & 2,19 & 1,69 \\
\hline Tarefa & Armacão & $50.488,97$ & 0,41 & 0,31 & 10 & 4,08 & 3,14 \\
\hline $\begin{array}{l}\text { Tarefa } \\
\end{array}$ & Concretagem & $30.473,20$ & 0,25 & 0,19 & & & \\
\hline
\end{tabular}


Verifica-se, com o exemplo das tabelas, que o critério de ponderação possui grande influência no cálculo.

$\mathrm{Na}$ Tabela 12, observa-se a diferença de avanço físico da tarefa fôrma, tanto em relação à etapa a que ela pertence, como em relação ao projeto como um todo.

Tabela 12 - Exemplo da diferença de avanço físico da tarefa fôrma

\begin{tabular}{ccc}
\hline Tipo de representatividade/ponderação & $\begin{array}{c}\text { Avanço Físico da } \\
\text { Atividade em relação } \\
\text { à Etapa }\end{array}$ & $\begin{array}{c}\text { Avanço Físico da } \\
\text { Atividade em relação ao } \\
\text { Projeto }\end{array}$ \\
\hline Duração & 2,52 & 1,01 \\
\hline Hh & 3,65 & 3,29 \\
\hline Custo & 2,19 & 1,69 \\
\hline
\end{tabular}

Verifica-se que o avanço físico do projeto também possui diferenças consideráveis, dependendo do critério considerado.

Tabela 13 - Exemplo da diferença de avanço físico da tarefa fôrma

\begin{tabular}{cc}
\hline Tipo de representatividade/ponderação & Avanço Físico do Projeto \\
\hline Duração & 20,31 \\
\hline Hh & 10,66 \\
\hline Custo & 12,77 \\
\hline
\end{tabular}

Os critérios foram detalhados, pois são relevantes na implementação do sistema, já que, dependendo do critério utilizado pela ferramenta de gestão, poderão ocorrer divergências consideráveis.

\subsubsection{Controle financeiro}

O PMBOK (2008) recomenda que, para o controle de custos, deve-se atentar aos seguintes pontos: 
- influenciar os fatores que criam mudanças na linha de base de custos autorizada;

- assegurar que todas as solicitações de mudança sejam feitas de maneira oportuna;

- gerenciar as mudanças reais conforme ocorrerem;

- assegurar que os gastos de custos não excedam os recursos financeiros autorizados, por período e total do projeto;

- monitorar o desempenho de custos para isolar e entender as variações a partir da linha de base de custos;

- monitorar o desempenho do trabalho em relação aos recursos financeiros gastos;

- prevenir que mudanças não aprovadas sejam incluídas no relato do custo ou do uso de recursos;

- informar as partes interessadas apropriadas a respeito das mudanças aprovadas e custos associados e

- agir para manter os excessos de custos não previstos dentro dos limites aceitáveis.

Ainda sobre o controle de custos, é importante procurar as causas das variações. Por exemplo, respostas inadequadas às variações de custos podem causar problemas de qualidade ou de cronograma ou produzir posteriormente um nível de risco inaceitável ao projeto. 


\subsubsection{Desempenho geral do projeto}

\section{a. "Earned value" ou valor agregado (VA)}

Segundo Oh-Cheol (2008), o "Earned Value" (EV) é uma técnica de controle de projetos utilizada em muitos países, que fornece uma medida quantitativa para integrar a programação e informações de custo. Além disso, ela também avalia a evolução do trabalho a fim de identificar possíveis atrasos e desvios de custos.

Para análise do Desempenho do Projeto, o PMI - Project Management Institute recomenda a metodologia do "Earned Value Analisys" que, segundo o PMBOK (2008), pode ser chamado também de Técnica do Valor Agregado - TVA.

o Valor Agregado é o valor do trabalho terminado expresso em termos do orçamento aprovado atribuído a esse trabalho para uma atividade do cronograma ou componente da estrutura analítica do projeto.

Assumpção (2007), em sua apresentação sobre as técnicas para planejamento de empreendimentos, conceitua "EVA - Earned Value Analisys" ou TVA - Técnica do Valor Agregado como a análise do desempenho obtido por meio da relação entre os custos reais incorridos e o trabalho realizado no projeto dentro de um determinado período de tempo. Ressalta, ainda, que o EVA é a avaliação entre o que foi obtido em relação ao que foi realmente gasto e ao que se planejava gastar, sendo o valor agregado a uma atividade, o valor orçado para ela, conforme exemplo no Quadro 14 e Gráfico 4.

Dados do Projeto:

- Custo: \$1000 (valor orçado - baseline)

- Prazo: 1 ano

- Disposição do Gasto: Linear

- Custo Trimestral: $\$ 250$

Fonte: ASSUNÇÃO (2007) - Apresentação sobre gerenciamento de custos do projeto

Quadro 14 - Exemplo de cálculo de valor agregado 


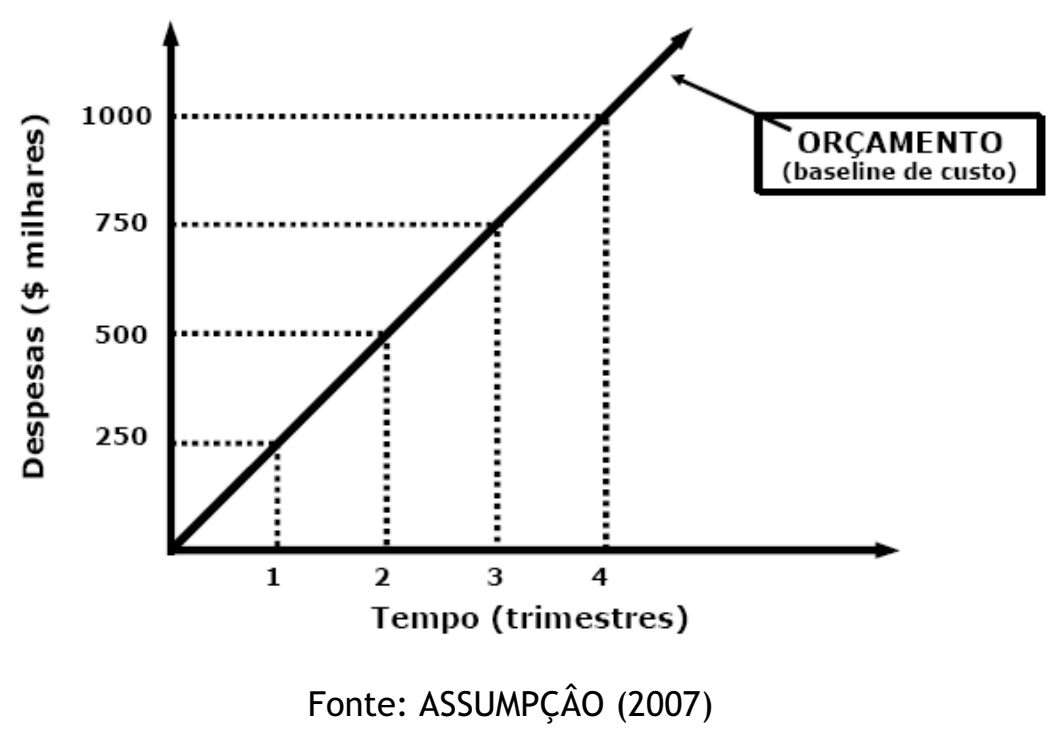

Gráfico 4 - Exemplo de distribuição linear - "Earned value"

O MS-Project (2007) utiliza o método do valor acumulado para indicar quanto do orçamento foi gasto em relação à quantidade de trabalho realizado até o momento e do custo da linha de base da tarefa, da atribuição ou dos recursos

Portanto, nas conceituações acima, tanto de Assumpção (2007) quanto do MSProject (2007), percebe-se que ambas nada mais são do que o mesmo método recomendado pelo PMI, ou seja, consiste, basicamente, em medir a performance, pela comparação do custo planejado do projeto em relação ao avanço físico, porém com nomenclaturas diferenciadas.

A técnica do valor agregado, descrita pelo PMBOK (2008), envolve também alguns valores chaves. Essa mesma técnica é utilizada no MS-Project (2007), porém é denominada análise do Valor Acumulado.

Para conceituação dos valores chave, primeiramente, preparou-se, no quadro 15, as diversas nomenclaturas utilizadas para os mesmos valores, definindo aquela a ser utilizada posteriormente. 


\begin{tabular}{|c|c|c|c|c|c|}
\hline $\begin{array}{l}\text { TERMO EM } \\
\text { INGLÊS }\end{array}$ & PMBOK (2008) & $\begin{array}{c}\text { MS-PROJECT } \\
\text { (2007) }\end{array}$ & $\begin{array}{c}\text { ASSUMPÇÃO } \\
\text { (2007) }\end{array}$ & $\begin{array}{c}\text { MATTOS } \\
\text { (2010) }\end{array}$ & $\begin{array}{c}\text { Nomenclatura } \\
\text { a ser adotada } \\
\text { pelo autor }\end{array}$ \\
\hline $\begin{array}{c}\text { BCWP - Budget } \\
\text { Cost Work } \\
\text { Performed - } \\
\text { Earned Value }\end{array}$ & $\begin{array}{l}\text { VA - Valor } \\
\text { Agregado }\end{array}$ & $\begin{array}{c}\text { COTR - Custo } \\
\text { Orçado do } \\
\text { Trabalho } \\
\text { Realizado }\end{array}$ & $\begin{array}{l}\text { Custo Orçado } \\
\text { do Trabalho } \\
\text { Executado ou } \\
\text { VA - Valor } \\
\text { Agregado }\end{array}$ & $\begin{array}{l}\text { VA - Valor } \\
\text { Agregado }\end{array}$ & $\begin{array}{l}\text { COTR - Custo } \\
\text { Orçado do } \\
\text { Trabalho } \\
\text { Realizado }\end{array}$ \\
\hline $\begin{array}{c}\text { BCWS - Budget } \\
\text { Cost Work } \\
\text { Scheduled }\end{array}$ & $\begin{array}{l}\text { VP - Valor } \\
\text { Planejado }\end{array}$ & $\begin{array}{l}\text { COTA - Custo } \\
\text { Orçado do } \\
\text { Trabalho } \\
\text { Agendado }\end{array}$ & $\begin{array}{l}\text { Custo Orçado } \\
\text { do Trabalho } \\
\text { Programado ou } \\
\text { VP - Valor } \\
\text { Planejado }\end{array}$ & $\begin{array}{l}\text { VP - Valor } \\
\text { Previsto }\end{array}$ & $\begin{array}{l}\text { COTA - Custo } \\
\text { Orçado do } \\
\text { Trabalho } \\
\text { Agendado }\end{array}$ \\
\hline $\begin{array}{l}\text { ACWP - Actual } \\
\text { Cost Work } \\
\text { Performed }\end{array}$ & CR- Custo Real & $\begin{array}{l}\text { CRTR - Custo } \\
\text { Real do } \\
\text { Trabalho } \\
\text { Realizado }\end{array}$ & $\begin{array}{l}\text { Custo Real ou } \\
\text { Custo Efetivo } \\
\text { do Trabalho } \\
\text { Executado }\end{array}$ & $\begin{array}{c}\text { CR - Custo } \\
\text { Real }\end{array}$ & $\begin{array}{c}\text { CRTR - Custo } \\
\text { Real do } \\
\text { Trabalho } \\
\text { Realizado }\end{array}$ \\
\hline
\end{tabular}

Os três valores chaves podem ser analisados com a utilização de Curva S. No Gráfico 5, verifica-se o exemplo, onde o CRTR (linha azul) e o COTR (linha vermelha) estão abaixo do COTA (linha preta).

Em outras palavras, o custo realizado (CRTR) até o momento é menor que o planejado (COTA), porém o trabalho realizado (COTR) em unidades financeiras também está abaixo do planejado. 


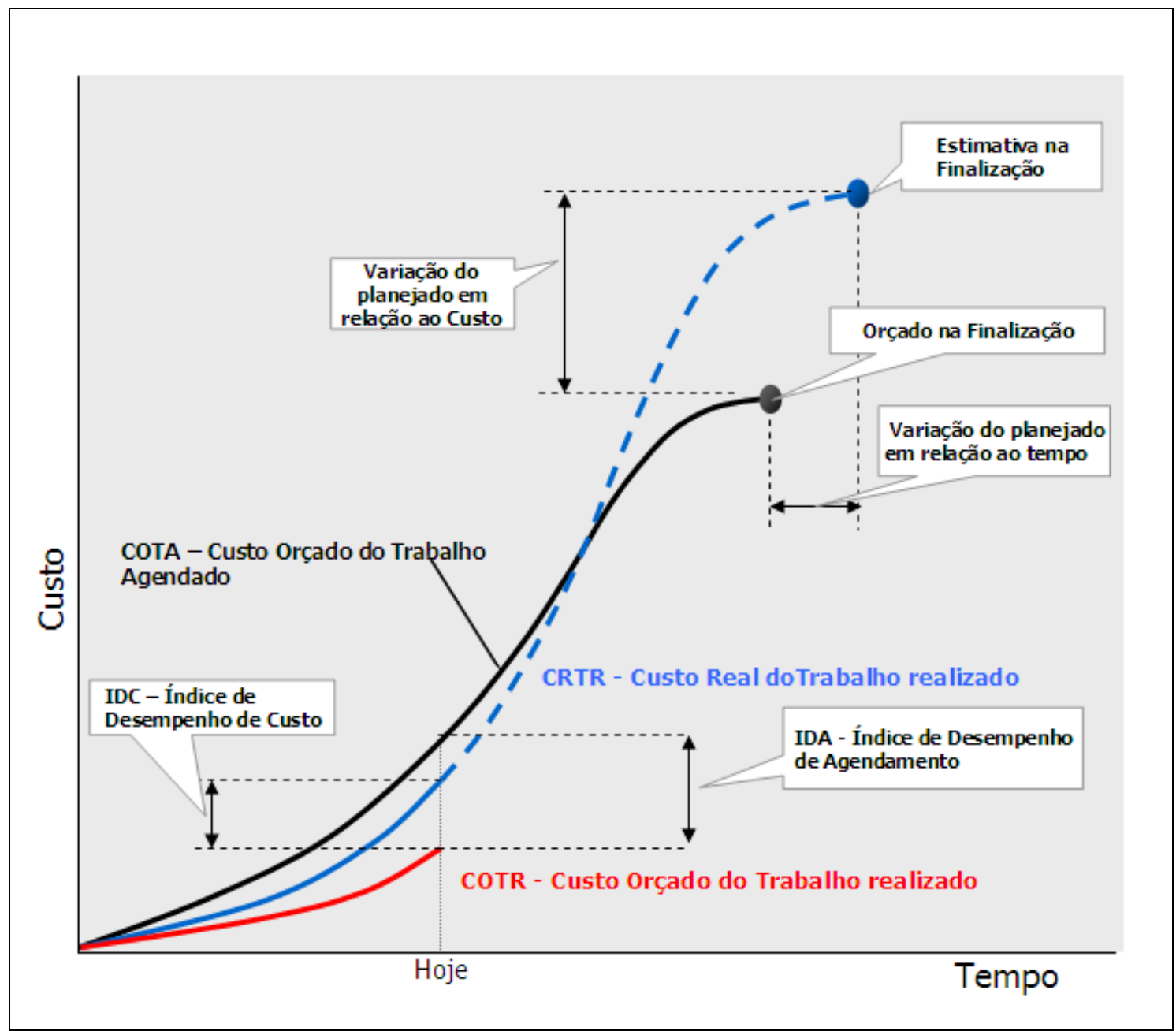

Gráfico 5 - Valor Agregado, valor planejado e custos reais

(Adaptação do PMBOK, 2008)

\section{- COTR - Custo Orçado do Trabalho Realizado}

O MS-Project (2007) define COTR como valor do trabalho realizado até a data de status, medido em unidade monetária. Esse valor é calculado para cada tarefa individual, mas é analisado em um nível de agregação (em geral, no nível do projeto).

No PMBOK (2004), o COTR é definido como a quantia orçada para o trabalho realmente terminado na atividade do cronograma ou no componente da EAP durante um determinado período de tempo. 
No quadro 16, é exemplificado o cálculo para Valor Agregado (COTR), onde se tem o custo planejado de R\$ 5.682.608,63 e um avanço físico do projeto, ou seja, um trabalho concluído equivalente a $46,42 \%$.

Custo Planejado = R\$ 5.682.608,63

Avanço Físico do projeto $=46,42 \%$

$$
\begin{array}{r}
\text { COTR = (Custo total Planejado }) \times(\% \text { avanço físico ponderado no custo }) \\
\text { Valor agregado }=(\mathrm{R} \$ 5.682 .608,63) \times(46,42) \\
\text { Valor agregado }=\mathrm{R} \$ 2.637 .613,73
\end{array}
$$

Quadro 16 - Exemplo de cálculo do COTR

\section{- COTA - Custo Orçado do Trabalho Agendado (Planejado)}

O valor do COTA é definido pelo MS-Project (2007) como o custo orçado de tarefas individuais, em conformidade com o agendamento dessas tarefas no plano de trabalho.

Já o PMBOK (2008) define como: "o orçamento autorizado designado para o trabalho a ser executado para uma atividade ou componente da estrutura analítica do projeto". Portanto, conclui-se que COTA é o custo planejado do projeto na sua linha de base, até a data de status.

Por exemplo, tomando como base um projeto específico, cujo custo total planejado é R\$6.135.468,83, a distribuição de custo ao longo do período de execução planejado é apresentada na Figura 13. Tem-se, na data de status, ou seja, na data de análise, que, no caso, é o mês de Julho/09, um COTA de $\mathrm{R} \$ 4.606 .924,60$, que se refere à somatória dos meses anteriores (Acumulado). 


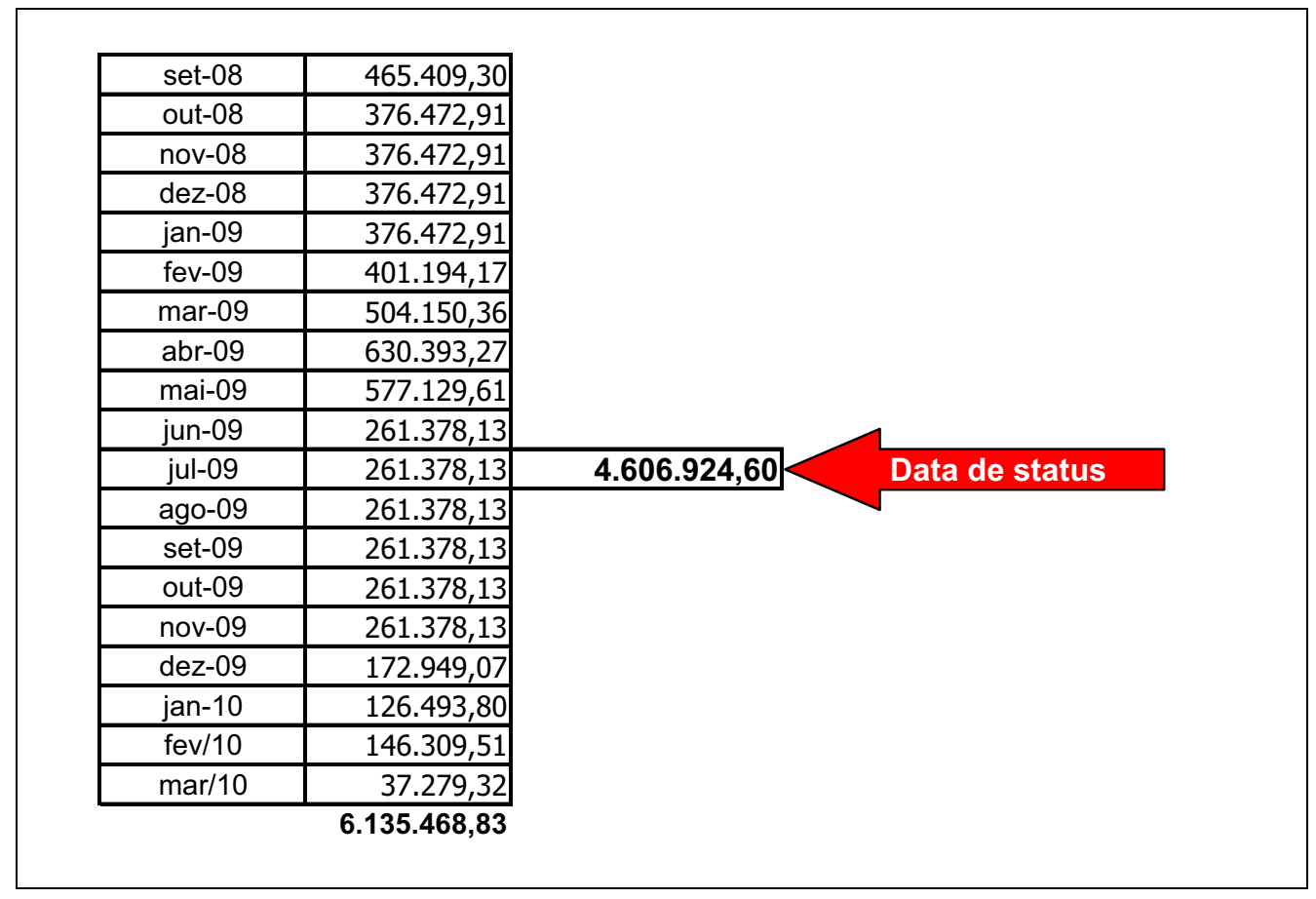

Figura 13 - Exemplo de COTA - Custo Orçado do Trabalho Agendado

- CRTR - Custo Real do Trabalho Realizado, também chamado de Custo Real

Segundo o PMBOK (2008), CRTR é o custo total incorrido e registrado na execução do trabalho para uma atividade ou para um componente da EAP.

Para o MS-Project (2007), o CRTR é o custo real necessário para concluir todas as tarefas ou partes delas até a data de status.

Portanto, entende-se por CRTR o custo efetivamente ocorrido para o avanço atual do projeto, ou seja, é o custo "realizado" do projeto.

\section{b. Indicadores de Desempenho}

O PMBOK (2008) recomenda a utilização de indicadores, pois refletem o desempenho de custo e de prazos de qualquer projeto e salienta que:

[...] os índices são úteis para determinar o andamento do projeto $e$ fornecer uma base para estimativa de custos e resultado dos prazos. (PMBOK, 2008, p.155) 
Os valores chaves conceituados no tópico "Earned value" ou valor agregado (VA), podem ser convertidos em indicadores de desempenho do projeto, entretanto, os indicadores utilizados para gestão possuem nomenclaturas diferenciadas entre autores.

No quadro 17, foram selecionadas as diversas nomenclaturas utilizadas para os mesmos indicadores, definindo aquela a ser utilizada posteriormente.

\begin{tabular}{|c|c|c|c|c|c|}
\hline $\begin{array}{c}\text { TERMO EM } \\
\text { INGLÊS }\end{array}$ & PMBOK (2004) & $\begin{array}{c}\text { MS-PROJECT } \\
\text { (2007) }\end{array}$ & $\begin{array}{c}\text { ASSUMPÇÃO } \\
\text { (2007) }\end{array}$ & MATTOS (2010) & $\begin{array}{c}\text { Nomenclatura a } \\
\text { ser adotada } \\
\text { pelo autor }\end{array}$ \\
\hline $\begin{array}{c}\text { CPI - Cost } \\
\text { Performance } \\
\text { Index }\end{array}$ & $\begin{array}{c}\text { IDC - Índice de } \\
\text { Desempenho de } \\
\text { Custo }\end{array}$ & $\begin{array}{c}\text { IDC - Índice de } \\
\text { Desempenho de } \\
\text { Custo }\end{array}$ & $\begin{array}{c}\text { IDC - Índice de } \\
\text { Desempenho de } \\
\text { Custo }\end{array}$ & $\begin{array}{c}\text { IDC - Índice de } \\
\text { Desempenho de } \\
\text { Custo }\end{array}$ & $\begin{array}{c}\text { IDC - Índice de } \\
\text { Desempenho de } \\
\text { Custo }\end{array}$ \\
\hline $\begin{array}{c}\text { SPI - Schedule } \\
\text { Performance } \\
\text { Index }\end{array}$ & $\begin{array}{c}\text { IDP - Índice de } \\
\text { Desempenho de } \\
\text { Prazo }\end{array}$ & $\begin{array}{l}\text { IDA- Índice de } \\
\text { Desempenho de } \\
\text { Agendamento }\end{array}$ & $\begin{array}{c}\text { IDP - Índice de } \\
\text { Desempenho de } \\
\text { Prazo }\end{array}$ & $\begin{array}{c}\text { IDP - Índice de } \\
\text { Desempenho de } \\
\text { Prazo }\end{array}$ & $\begin{array}{c}\text { IDP - Índice de } \\
\text { Desempenho de } \\
\text { Prazo }\end{array}$ \\
\hline $\begin{array}{c}\text { TCPI - To } \\
\text { complete } \\
\text { Performance } \\
\text { Index }\end{array}$ & $\begin{array}{l}\text { IDPT - Índice de } \\
\text { Desempenho } \\
\text { para Término }\end{array}$ & $\begin{array}{l}\text { IDAC - Índice de } \\
\text { Desempenho a } \\
\text { Concluir }\end{array}$ & (não disponível) & $\begin{array}{l}\text { IDCR - Índice de } \\
\text { Desempenho de } \\
\text { Custo de } \\
\text { Recuperação }\end{array}$ & $\begin{array}{c}\text { IDAC - Índice de } \\
\text { Desempenho a } \\
\text { Concluir }\end{array}$ \\
\hline
\end{tabular}

Quadro 17 - Nomenclaturas utilizadas para os indicadores de performance do projeto

\section{- IDC - Índice de desempenho de custo}

No MS-Project (2007), os campos IDC (índice de desempenho de custo) mostram a razão entre os custos orçados (ou de linha de base) e os custos reais do trabalho realizado, até a data de status do projeto ou a data atual.

O mesmo é conceituado pelo PMBOK (2008) como a relação entre o COTA (VA) e o CRTR (CR), sendo que, o IDC menor que 1,0 indica um estouro nos custos 
estimados. Já, um valor maior que 1,0 indica que os custos estimados não foram atingidos.

Por exemplo, no caso do valor de IDC igual a 0,50, entende-se que o projeto está custando o dobro do planejado, pois tem uma efetividade de $50 \%$ do valor aplicado.

Esse índice é dado conforme a Fórmula 3:

$$
I D C=\frac{\text { COTR }}{\text { CRTR }}
$$

Fórmula 3 - Fórmula do IDC - Índice de desempenho de custo

\section{- IDP - Índice de desempenho de prazo}

$O$ índice de desempenho de prazo pode ser entendido como a velocidade relativa ao previsto à execução. E, de acordo com o PMBOK (2004) é usado em adição ao andamento do cronograma para prever a data de término. O PMBOK (2008) salienta, ainda que, às vezes o indicador é usado junto com o IDC para prever as estimativas de término do projeto.

Com isso, entende-se que, se esse índice for menor que 100\%, o projeto está atrasado e, se for igual a $100 \%$, os prazos estão sendo cumpridos exatamente conforme o planejado.

Esse índice é dado pela Fórmula 4.

$$
\operatorname{IDP}=\frac{\text { COTR }}{\text { COTA }}
$$




\section{- IDAC - Índice de desempenho a concluir}

No MS-Project (2007), o IDAC (índice de desempenho a concluir) mostra a razão entre o trabalho restante a ser concluído e os fundos restantes a serem gastos, na data de status.

O PMBOK (2008) define o IDAC como a projeção calculada do desempenho de custos que deve ser alcançado no trabalho restante para atender um objetivo de gerenciamento especificado. Ou seja, é a proporção entre o trabalho restante e os recursos financeiros restantes, conforme Fórmula 5.

$$
\text { IDAC }=\frac{\text { ONT }- \text { COTR }}{\text { ONT }- \text { CRTR }}
$$

Onde:

ONT = Orçamento no Término (PMBOK, 2008)

Fórmula 5 - Fórmula do IDAC - Índice de desempenho a concluir

Por exemplo, tendo-se uma tarefa com custo da linha de base (OAT) de R\$200,00, COTR de $R \$ 125,00$ e CRTR de $R \$ 150,00$, o IDAC é 1.5, o que indica desempenho ruim até a data do status. Isso significa que, para completar o projeto dentro do orçamento, será necessário melhorar o desempenho.

Mattos (2010) observa, ainda, o seguinte aspecto em relação ao indicador:

Pesquisas conduzidas nos Estados Unidos da América mostram que um projeto dificilmente se recupera se, a $20 \%$ de execução, tiver o IDAC superior em mais de 10\% ao IDC. (MATTOS, 2010, p.368)

Ou seja, a partir dos $20 \%$ do projeto, historicamente, o final projetado não varia mais do que $\pm 10 \%$, reforçando a tese de que, quanto mais tarde forem as ações para recuperação do prazo, mais difícil será recuperar os custos previstos.

Portanto, ao detectar-se um número alto do indicador, é prudente reorçar o projeto (MATTOS, 2010). 
"Mas, o planejamento só é ético quando visa um crescimento que possa se traduzir em melhor qualidade da vida coletiva, um cenário melhor para a vida de todos, e só é democrático quando procura incorporar todos os envolvidos no processo de planejar."

João Caramez

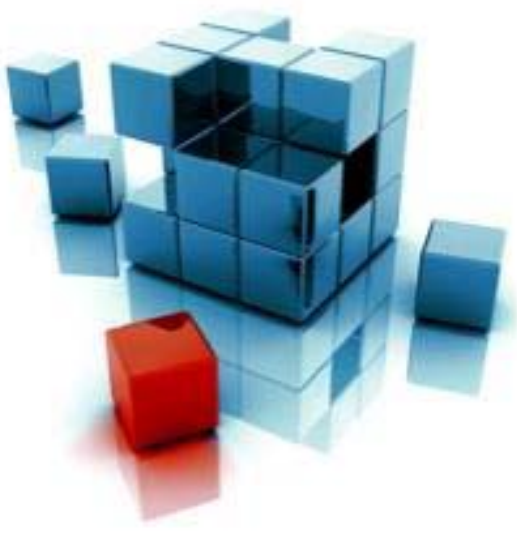




\section{Implementação de sistema integrado para gestão de contratos}

O capítulo, a seguir, apresentará uma breve introdução quanto à implementação de sistemas de gestão em empresas construtoras. Na sequência, serão descritos os motivos para a implementação de um sistema de gestão de contratos, focando os benefícios trazidos por ele, como: governança corporativa, disciplina, organização, padronização e rastreabilidade.

Posteriormente, será abordado o aspecto da aplicação da ferramenta dentro das necessidades das empresas construtoras e, a partir dessa análise e apoiando-se nas entrevistas realizadas com profissionais da área de implementação do sistema, são relacionadas as ferramentas disponíveis no mercado.

Finalizando, é apresentado um estudo mais aprofundado do EBS, principalmente com relação à aplicação das práticas de gestão de contrato, visto que as empresas consultadas nos estudos de caso realizaram a implementação do EBS para gestão de seus contratos.

\subsection{Implementação de sistemas em empresas construtoras}

A tradicional e conservadora indústria da construção civil tem, nos últimos anos, tentado acompanhar a evolução de outros setores da indústria, na adoção de novas e modernas tecnologias, em busca de maior qualidade, eficiência e produtividade. Porém, Nascimento et al. (2003) ressaltam que o sucesso na implementação dessas tecnologias não necessariamente garante a eficácia do negócio. Em um cenário de mercados acirrados, em que a competitividade é um fator primordial para a sobrevivência do negócio, não ser eficaz pode significar o fim da empresa. O desafio atual é conseguir eficácia mesmo em um setor com poucos recursos para investir em avanços tecnológicos e capacitação de profissionais. 
Com isso, entende-se que a implementação de uma nova tecnologia, ou também um sistema, não garante sozinha a eficácia dos processos de gestão da empresa, já que muitos outros aspectos estão envolvidos.

Bernardes (2003) enfatiza que o sucesso da implementação de sistemas de informações depende do tamanho do projeto e da maneira pela qual ele está estruturado, como também da experiência da empresa com a implementação de inovações similares. E ressalta:

Quanto maior o tamanho do projeto, maior a probabilidade de falha na implementação do sistema. Entretanto, na medida em que o projeto é desenvolvido de maneira estruturada e a empresa já participou de processo similar, torna-se fácil a implementação do mesmo. (BERNARDES, 2003, p.44)

Portanto, para funcionar plenamente, Riccio (1998) apud Valente (2004) salienta que a ferramenta necessita de recursos, tanto físicos como humanos, que podem ser representados pelo [...] "conjunto de tudo aquilo que está dentro ou entra no sistema para ser utilizado durante o processo de transformação".

Contudo, para diminuir o risco de falhas, Bernardes (2003) evidencia que os agentes responsáveis pelo processo devem discutir com os envolvidos, bem como assegurar que os usuários do novo sistema se sintam confortáveis com a sua utilização.

Com base no exposto, verifica-se que existem, além de uma série de aspectos apresentados nos capítulos anteriores, outros como:

- organizar os macroprocessos que permeiam o sistema a ser implementado;

- enraizar na empresa os conceitos básicos de planejamento, conforme apresentado no capítulo de definições, e o diagnóstico das práticas de gestão de contratos. 
A empresa deverá observar também que inovações gerenciais implicam mudanças na organização que, por sua vez, esbarram em problemas culturais, provenientes da influência do comportamento organizacional (BERNARDES, 2003).

Ainda, no segmento da construção civil, verifica-se que o que falta para ela se tornar tão informatizada quanto outros segmentos - como as indústrias, que trabalham em série - é a organização e a disciplina. A barreira cultural e a terminologia confusa do setor dificultam a organização dos dados. A isso tudo se soma a baixa escolaridade dos operários, o que torna ainda distante o sonho do canteiro “hiperintegrado" (LOTURCO, 2004).

Mesmo, partindo da premissa de que tudo está enraizado e já funciona bem na empresa, Boyadjian (2008) revela que as empresas têm enfrentado grandes problemas com implementações de novas estratégias para os processos de gestão, enfatizando que diversos estudos apontam que o insucesso se dá por alguns fatores, como:

- O tempo de implementação é maior do que o planejado;

- Os problemas enfrentados não são previstos;

- As atividades são coordenadas de forma ineficaz e/ou mal definidas;

- Os funcionários não têm as competências necessárias;

- Os treinamentos aos funcionários são inadequados;

- Fatores externos são incontroláveis;

- A liderança é inadequada e falta suporte;

- Há falha na comunicação vertical;

- As metas não são tão bem compreendidas;

- O nível gerencial não trabalha em equipe;

- A alta direção não avalia realisticamente se a empresa consegue executar o plano (BOSSIDY e CHARAN apud BOYADJIAN 2008); 
- Crises e prioridades conflitantes comprometem a atenção necessária à implementação (falta disciplina de execução);

- Os principais formuladores das estratégias não participam ativamente da implementação;

- Os sistemas de informações são inadequados;

- Há resistência à mudança, não iniciando o processo (pouca prioridade);

- Impaciência - as mudanças têm que acontecer o quanto antes. CEOS ${ }^{26}$ podem ser inflexíveis e quererem a mudança "para ontem";

- Falta de celebração do sucesso, ausência de reconhecimento e recompensa pelo progresso (WHEELEN et al., 2002 apud BOYADJIAN, 2008).

Por outro lado, Moraes e Serra (2009) enfatizam que a eficácia de uma das mais promissoras soluções tecnológicas para o setor da construção civil é a ( $\mathrm{Tl})$, que pode ser adotada com investimentos moderados.

Observam que a competitividade das empresas do setor da construção civil depende da gestão eficiente de seus sistemas de programação e controle da produção (MORAES e SERRA 2009). Portanto, o planejamento de obras por meio de modelos mais eficientes vem deixando de ser um ideal para transformar-se em realidade nas empresas, como estratégia de melhoria da qualidade de seus produtos e do aumento de sua competitividade frente ao mercado em que atua.

Loturco (2004), em sua matéria sobre "Tecnologias da Informação", que foca as soluções que tornam possível o compartilhamento de projetos e controle in loco das obras, salienta que não faltam ferramentas para integração plena da construção civil e destaca: "especialistas garantem que é possível desenvolver ou adaptar, em pouco tempo, sistemas que supram qualquer necessidade do setor na verdade, muitas dessas tecnologias já estão disponíveis".

\footnotetext{
${ }^{26}$ CEO = é o título que pode ser dado ao mais alto cargo executivo de uma organização (Diretor executivo ou Diretor geral).
} 
Com base nessa afirmação, constata-se que há idéias simplórias com relação à implementação de ferramentas para planejamento e controle da obra, Cardoso (2009) cita em seu livro de forma bastante resumida, o seguinte:

Cabe ao profissional, escolher o software que melhor se identifique com as suas necessidades profissionais, decidir por matricular-se num curso intensivo de 20 horas, e, em duas semanas estar apto a realizar pequenos planejamentos (CARDOSO, 2009, p.160).

Neto (2006) em entrevista sobre "Gestão", cita o seguinte:

A maior clareza dos objetivos e necessidades da empresa facilita a avaliação do software mais adequado. Para isso, é importante que a empresa liste em um documento todos os requisitos desejáveis no sistema (NETO, 2006, p.12).

Com isso, entende-se que, para a ferramenta ter aderência nos processos de gestão da empresa construtora, é necessário um estudo preliminar apontando os motivos para implementação da ferramenta, os levantamentos das suas reais necessidades e, só a partir daí, pode-se sair em busca da ferramenta de mercado que melhor se enquadre no escopo predefinido.

No quadro18, são conceituados os sistemas disponíveis para construção e sua área de abrangência, ressaltando que a implementação de sistemas para gestão de contratos, título deste trabalho, refere-se ao "Sistema para Gerenciamento de obras" citado no quadro a seguir.

\begin{tabular}{|c|c|c|c|}
\hline Elaboração de projetos & Gerenciamento de obras & Gestão de empresas (ERP) & Especialistas \\
\hline $\begin{array}{c}\text { Arquitetura } \\
\text { Estruturas } \\
\text { Elétrica } \\
\text { Hidráulica } \\
\text { Ar-condicionado } \\
\text { Paisagismo } \\
\text { Gerenciamento de projetos } \\
\text { (colaboração) }\end{array}$ & $\begin{array}{c}\text { Orçamento } \\
\text { Planejamento } \\
\text { Controle } \\
\text { Fiscalização } \\
\text { Suprimentos } \\
\text { Levantamento de quantidades }\end{array}$ & $\begin{array}{c}\text { Suprimentos } \\
\text { Imobiliário } \\
\text { RH } \\
\text { Medicina e segurança do } \\
\text { trabalho } \\
\text { Contabilidade } \\
\text { Contas correntes } \\
\text { Contas a pagar e a receber } \\
\text { Fluxo de caixa } \\
\text { Orcamento empresarial }\end{array}$ & $\begin{array}{c}\text { Estudo de viabilidade } \\
\text { PIT (Pyle Integrity Test) } \\
\text { PDA (Pyle Driver Analyzer) } \\
\text { Jurídico } \\
\text { (controle de processos e } \\
\text { contratos })^{*} \\
\text { Qualidade }\left(^{*}\right)\end{array}$ \\
\hline
\end{tabular}

Quadro 18 - Sistemas para construção (Fonte: LOTURCO, 2004) 


\subsection{Motivos para implementação de ferramenta de gestão}

Em contato com os profissionais da área de implementação de sistema para planejamento e controle de construtoras, constata-se que o processo de implementação de uma ferramenta para gestão de contratos geralmente é motivada pelos diversos benefícios, dela advinda, dentre eles: governança corporativa, disciplina, organização, padronização e rastreabilidade, conforme descritos nos itens a seguir.

\subsubsection{Governança corporativa}

O termo governança corporativa foi criado no início da década de 1990 nos países desenvolvidos, mais especificamente nos Estados Unidos e na Grã-Bretanha. Segundo Garcia (2005), a governança corporativa serve para definir as regras que regem o relacionamento dentro de uma companhia dos interesses de acionistas controladores, acionistas minoritários e administradores.

O IBGC- Instituto Brasileiro de Governança Corporativa criado, em 1994, com a missão de "ser referência em governança corporativa, contribuindo para o desempenho sustentável das organizações e influenciando os agentes de nossa sociedade no sentido de maior transparência, justiça e responsabilidade”, define a Governança corporativa da seguinte forma:

[...] sistema que assegura aos sócios-proprietários o governo estratégico da empresa e a efetiva monitoração da diretoria executiva. A relação entre propriedade e gestão se dá através do conselho de administração, a auditoria independente e o conselho fiscal, instrumentos fundamentais para o exercício do controle. A boa governança corporativa garante equidade aos sócios, transparência e responsabilidade pelos resultados (accountability).

Observa, ainda, que a empresa que opta pelas boas práticas de Governança Corporativa adota como linhas mestras a transparência, a prestação de contas, a 
equidade e a responsabilidade corporativa (IBGC, 1994), conforme caracterizadas a seguir.

- Transparência: [...] é o desejo de disponibilizar para as partes interessadas as informações que sejam de seu interesse e não apenas aquelas impostas por disposições de leis ou regulamentos. A adequada transparência resulta um clima de confiança, tanto internamente, quanto nas relações da empresa com terceiros. Não deve restringir-se ao desempenho econômico-financeiro, contemplando também os demais fatores (inclusive intangíveis) que norteiam a ação gerencial e que conduzem à criação de valor.

- Equidade: caracteriza-se pelo tratamento justo de todos os sócios e demais partes interessadas (stakeholders). Atitudes ou políticas discriminatórias, sob qualquer pretexto, são totalmente inaceitáveis.

- Prestação de contas: (accountability): os agentes de governança devem prestar contas de sua atuação, assumindo integralmente as consequências de seus atos e omissões.

- Responsabilidade: os agentes de governança devem zelar pela sustentabilidade das organizações, visando à sua longevidade, incorporando considerações de ordem social e ambiental na definição dos negócios e operações.

\subsubsection{Disciplina}

A disciplina definida por Michaelis (2010) é caracterizada pelo conjunto de obrigações que regem a vida de certas corporações.

Disciplinar uma construtora, do ponto de vista da gestão de contratos, consistiria, resumidamente, em impor um conjunto de processos e restringir outros, de forma que a análise das informações, por exemplo, para tomada de decisões possa ser executada sempre da mesma forma em qualquer contrato.

\subsubsection{Organização}

Nunes (2008) recorre ao conceito clássico de organização, definindo-a como: 
atuando num determinado contexto ou ambiente, com vista a atingir um objetivo predeterminado através da afectação eficaz de diversos meios $e$ recursos disponíveis, liderados ou não por alguém com as funções de planejar, organizar, liderar e controlar. (NUNES, 2008)

Dessa forma, entende-se que a organização no sistema de gestão de contratos se dá pelo fato de todos os membros do projeto terem acesso à mesma base de dados e possuírem as mesmas informações relativas ao projeto, podendo, seja em grupo ou individualmente, coordenar e controlar com vista a atingir o objetivo predeterminado.

Além disso, a organização pode ser aplicada nos macroprocessos, definindo o contexto e ambiente em que cada membro do projeto atuará, de forma ordenada e coordenada.

\subsubsection{Padronização}

SOUTO (2003) apresenta, em seu artigo, as diversas definições de padronização, conforme descrito abaixo:

Padronizar significa igualar, uniformizar e, para Aurélio Buarque de Holanda Ferreira, padronização é a redução dos objetivos do mesmo gênero a um só tipo, unificado e simplificado, segundo um padrão ou modelo preestabelecido.

[...] Padronizar significa igualar, uniformizar, estandardizar. Padronização, por sua vez, quer dizer adoção de um estander, um modelo. A palavra 'principio' indica o básico, o elementar. (SOUTO, 2003)

Exemplifica o termo padronização da seguinte forma:

[...] assim, deve a entidade compradora, em todos os negócios para a aquisição de bens, observar as regras básicas que levam à adoção de um estander, de um padrão que, vantajosamente, possa satisfazer as necessidades das atividades que estão a seu cargo [...] (SOUTO, 2003)

Faria (2008) ressalta, sob o aspecto gerencial, que a padronização garante, na ausência de qualquer empregado, por qualquer motivo, que haja um padrão que define o que deve ser feito e como deve ser feito. Com isso o conhecimento 
permanece na empresa, e não somente na cabeça de uns poucos funcionários, servindo também de base para o treinamento de novos empregados. Ajuda e alavanca a comparação e a disseminação do conhecimento, dentro da empresa.

Portanto, tomando como base as definições anteriores, entende-se que, para o sistema de gestão de contratos, a padronização está na forma como as informações são carregadas no sistema, bem como na uniformização das informações geradas pelo sistema e na forma como estas são visualizadas por todos os membros do projeto.

\subsubsection{Rastreabilidade}

A rastreabilidade é uma característica que está há mais de trinta anos incorporada na gestão de qualidade das linhas de montagem da indústria aeroespacial, sobre o aspecto do controle de qualidade dos sistemas espaciais da NASA, onde parece ter sido originada (CHAPAVAL et al. 2008).

Pode ser conceituada, segundo Dyer (1960 apud Chapaval et al. 2008), como a capacidade de recuperação do histórico, da aplicação ou da localização de uma entidade (ou item) por meio de identificações registradas.

Portanto, entende-se que a rastreabilidade é a capacidade de rastrear um elemento do projeto a outros elementos correlatos com a finalidade principal de se compreender a origem.

No sistema de gestão de contratos, a rastreabilidade permite, por exemplo, gerenciar e avaliar os impactos das mudanças ocorridas no escopo do projeto, nos custos e prazos. 


\subsection{Levantamento das necessidades das empresas}

Para levantamento das necessidades da empresa, Amorim (2006), professor da Universidade Federal Fluminense, que desenvolve linha de pesquisa em tecnologia de informação para a construção, destaca que, primeiramente, a construtora deverá delimitar a extensão da cobertura do software, ou seja, delimitar o alcance da funcionalidade nos processos, pois o princípio básico do software de gestão é a compatibilidade com processos internos.

Segundo Amorim (2006), o conhecimento dos processos é o principal problema, pois a maioria das construtoras não tem os processos definidos, gerando conflitos na implementação.

Com isso, Benac et al. (2004) ressaltam que, antes de iniciar a implementação, é necessário o estudo dos processos de gestão e da estrutura organizacional da empresa, avaliando não apenas as atividades que ocorrem dentro da empresa, mas também a integração dos parceiros externos. Após esse estudo, é recomendável elaborar o modelo, priorizar o desenho negociado do conjunto de procedimentos, processos de decisão e fluxos de informação que definem os vários níveis da arquitetura proposta.

Portanto, para o conhecimento dos processos e consequente redesenho deles é importante o apoio dos profissionais envolvidos nos processos em todos os níveis de gestão.

Neto (2006) ainda destaca que a construtora deverá observar seus processos e organizar as suas prioridades para a automatização, antes de procurar um fornecedor do sistema. Assim, será possível um estudo para a padronização dos processos por meio de ferramenta adequada para tal fim.

Cabe ressaltar que, nas entrevistas realizadas com profissionais da área de implementação de sistemas, foi citado que há empresas, no mercado, 
especializadas na implementação e que apoiam as construtoras já no estudo inicial dos processos.

\subsection{Processo de escolha do sistema de gestão}

O processo de escolha do sistema de gestão de contratos passa por três etapas, segundo o especialista Neto (2006):

- Avaliação: pré-seleção, avaliação técnica e teste prático;

- Fechamento: negociação, contratação e planejamento;

- Implementação: capacitação, customização, adaptações e testes integrados.

\subsubsection{Avaliação das ferramentas disponíveis no mercado}

A etapa de avaliação envolve uma pré-seleção, avaliação técnica e um teste prático antes da compra. Como é inviável assistir a uma série de demonstrações de empresas de softwares, Neto (2006) recomenda o envio prévio aos fornecedores de um questionário sobre a funcionalidade do sistema nas diversas áreas da empresa.

Esse questionário deverá ter um peso atribuído para cada item, de acordo com a relevância da área para a empresa. Após esse processo, selecionam-se as empresas que obtiveram as melhores médias finais para a apresentação de seus sistemas.

Com isso, para a avaliação dos sistemas pré-selecionados, Neto (2006) destaca a importância da participação de especialistas das diversas áreas da empresa para averiguar a funcionalidade da ferramenta no setor em que cada um é responsável. Complementa que a decisão deve ser conjunta e não apenas do empresário. 
Vale a pena ressaltar que algumas fornecedoras cedem o software por um período determinado, com o objetivo de se fazer testes práticos, o que poderá facilitar a escolha da ferramenta.

\subsubsection{Contratação e planejamento para implementação da ferramenta}

A segunda etapa de avaliação envolve negociação, contratação e planejamento. Embora as empresas desenvolvedoras do sistema, geralmente, façam sua implementação, há aquelas especializadas na implementação de vários sistemas, não sendo necessariamente uma desenvolvedora ${ }^{27}$.

Ainda, nessa etapa, deve ser realizado o planejamento, que deve tratar basicamente do tempo da implementação parcial de cada módulo e do software total. Esse cronograma tem de ser estabelecido para que possa ser exigida a entrega das ferramentas no prazo previsto, até mesmo para que o atraso não implique prejuízos no desenvolvimento dos serviços da empresa (NETO, 2006).

\subsubsection{Implementação da ferramenta escolhida}

A última etapa é a implementação, que engloba a capacitação, a customização e adaptações e testes. Neto (2006) destaca que se deve considerar ainda o tempo para a capacitação dos usuários e que: “essa capacitação deve ser contínua, de acordo com a atualização do software e da própria mudança de funcionários ao longo do tempo".

Quanto a customizações e adaptações, é importante a empresa ter um plano das

\footnotetext{
${ }^{27}$ Informações obtidas nas entrevistas realizadas com profissionais da área de implantação de sistemas (veja no apêndice $\mathrm{C}$ o questionário utilizado).
} 
aplicações fundamentais para seu negócio e que o fornecedor não tem, para que seja desenvolvido com o tempo (NETO, 2006).

Também é recomendável a realização de testes paralelos dos aplicativos do software, ou seja, utilizar o sistema novo e antigo por um período de tempo, comparando os resultados de forma a validar as respostas da nova ferramenta.

Benac et al. (2006) destacam que, na fase de implementação do sistema, é indispensável buscar o efetivo comprometimento da alta direção e dos usuárioschave, de modo a reduzir as chances de resistências ativa ou passiva, causadores potenciais de desistência e/ou baixo nível de utilização dos sistemas.

Além disso, como o conjunto dos sistemas propostos lida com conceitos avançados, os usuários deverão receber atenção especial quanto a sua qualificação, grau de rotatividade e visão integrada dos negócios da empresa (BENAC, 2006).

\subsection{Ferramentas disponíveis no mercado}

Com base em um estudo exploratório ${ }^{28}$ das ferramentas disponíveis no mercado para gestão de contratos, utilizando-se de informações existentes em sites e apoiando-se nas entrevistas com profissionais da área de implementação de sistemas e da área de planejamento e controle de algumas empresas, foram identificados alguns sistemas de gestão de contratos disponíveis no mercado, conforme relacionado a seguir:

- EBS $^{29}$

- $\operatorname{JDE}^{30}$

- MEGA $^{31}$

\footnotetext{
${ }^{28}$ Conforme mencionado no item 1.4.3.

${ }^{29}$ EBS - site: http://www.oracle.com.br

${ }^{30}$ JDE - site: http://www.oracle.com.br
} 
- PRIMAVERA ${ }^{32}$

- $\mathrm{RM}^{33}$

- SAP $^{34}$

- $\quad$ STAR SOFT ${ }^{35}$

- UAU ${ }^{36}$

Entretanto, esses profissionais ressaltaram que alguns não atendem plenamente as práticas de gestão, inclusive havendo divergências de opiniões com relação a esse assunto.

Mas, cabe salientar que não se pretende, com este trabalho, qualificar nem homologar os sistemas de gestão de contratos disponíveis, mas apresentar tópicos que permitam uma melhor análise do sistema, antes da escolha e implementação.

Dessa forma, foi escolhido, como base para o estudo, o EBS, pois foi citado pelos profissionais especialistas em implementação de sistemas, além de ser analisado também nos estudos de casos.

\subsubsection{Caracterização do EBS - E-Business Suite}

A Oracle, que está há mais de trinta anos no mercado, pode ser encontrada em quase todos os setores do mundo e nos escritórios de 98 das empresas citadas na lista "Fortune 100", sendo a primeira empresa de software a desenvolver e

\footnotetext{
${ }^{31}$ Mega - site: http://www.mega.com.br

${ }^{32}$ Primavera - site: http://www.primaverabss.com

${ }^{33}$ RM - site: http: / /www.rmsistemas.com.br

${ }^{34}$ SAP - site: http: / /www.sap.com

${ }^{35}$ Star Soft - site: http://www.starsoft.com.br

${ }^{36}$ UAU - site: http://novosite.empresarial.ws/
} 
empregar software empresarial totalmente habilitado para internet em toda a sua linha de produtos: banco de dados, aplicativos empresariais e ferramentas para desenvolvimento de aplicativos e suporte a decisões.

Como principal fornecedor de software para gerenciamento de informações, a Oracle é a segunda maior empresa de software independente do mundo. Atualmente está comprometida em garantir que todo os seus sistemas sejam projetados para trabalhar em conjunto (a abordagem de suite).

Desenvolvedora do EBS - E-Business Suite, que é um produto habilitado para internet, pode ser gerido a partir de um único site, possibilitando que a empresa possa operar um banco de dados único.

Padilha et al. (2004) observam que esse tipo de ferramenta é um instrumento para a melhoria de processos como a produção, compras ou distribuição, já que as informações on-line são geradas em tempo real.

A versão 12 lançada em fevereiro de 2007 contém uma série de funcionalidades e pode ser caracterizada como um ERP, pois agrega além das funcionalidades de um sistema de gerenciamento de projetos, aquelas relativas à gestão da empresa como um todo.

Por possuir abrangência internacional, o sistema é multilíngue, sendo que, no Brasil, tem como principal concorrente apenas o sistema SAP, com as mesmas características.

Entretanto, dentre as principais vantagens em relação ao SAP, está a fundamentação total da ferramenta nos conceitos do PMI e a completa integração com o MS-Project, software bastante conhecido no planejamento e controle de projetos.

No que diz respeito às funcionalidades relativas à gestão de contratos, o EBS possui quatro módulos específicos para gestão integrada do projeto. São eles: 
- Project Management: gestão de cronograma e escopo

- Costing: gestão de custos

- Billing: gestão da receita

- Collaboration: gestão do escopo

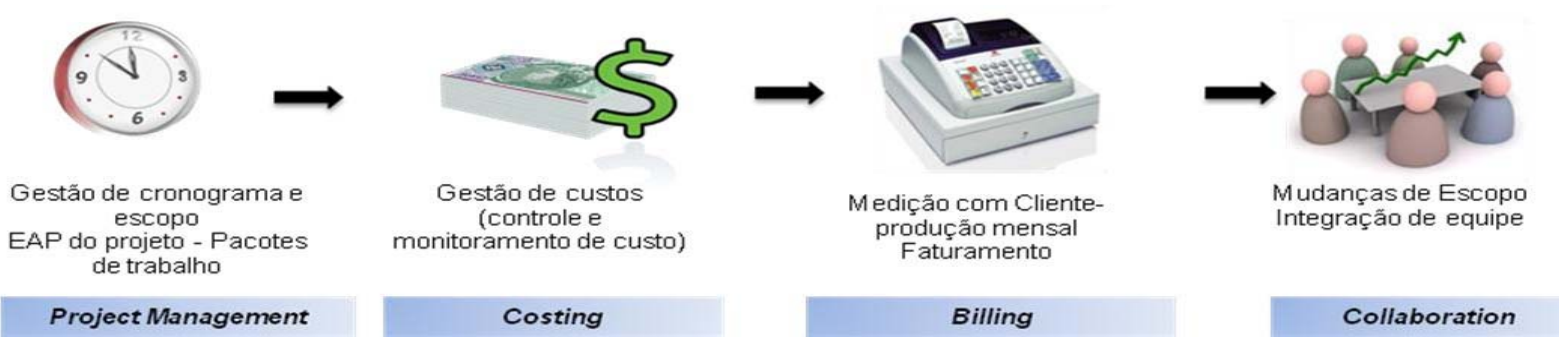

Figura 14 - Módulos do sistema EBS (Fonte: ORACLE, 2010)

\subsubsection{Aplicação das práticas de gestão de contratos no EBS}

Padilha et al.(2004) observam que a implementação de um sistema integrado proporciona para a empresa grande oportunidade de aplicação e uso das técnicas de planejamento.

Com base nisso, na revisão bibliográfica e em estudos empíricos, realizou-se análise em relação à aplicabilidade dos níveis de gestão dos processos e práticas de gestão com a ferramenta, lembrando que todo o seu desenvolvimento está fundamentado nos conceitos e práticas recomendadas pelo PMI e na integração com o MS-Project.

Nas figuras apresentadas, a seguir, podem ser visualizadas as telas da ferramenta e as práticas de planejamento e gestão aplicados. 
- Nível de gestão: a ferramenta permite, por meio dos perfis de acesso, a separação das informações por nível hierárquico, conforme figura 15.

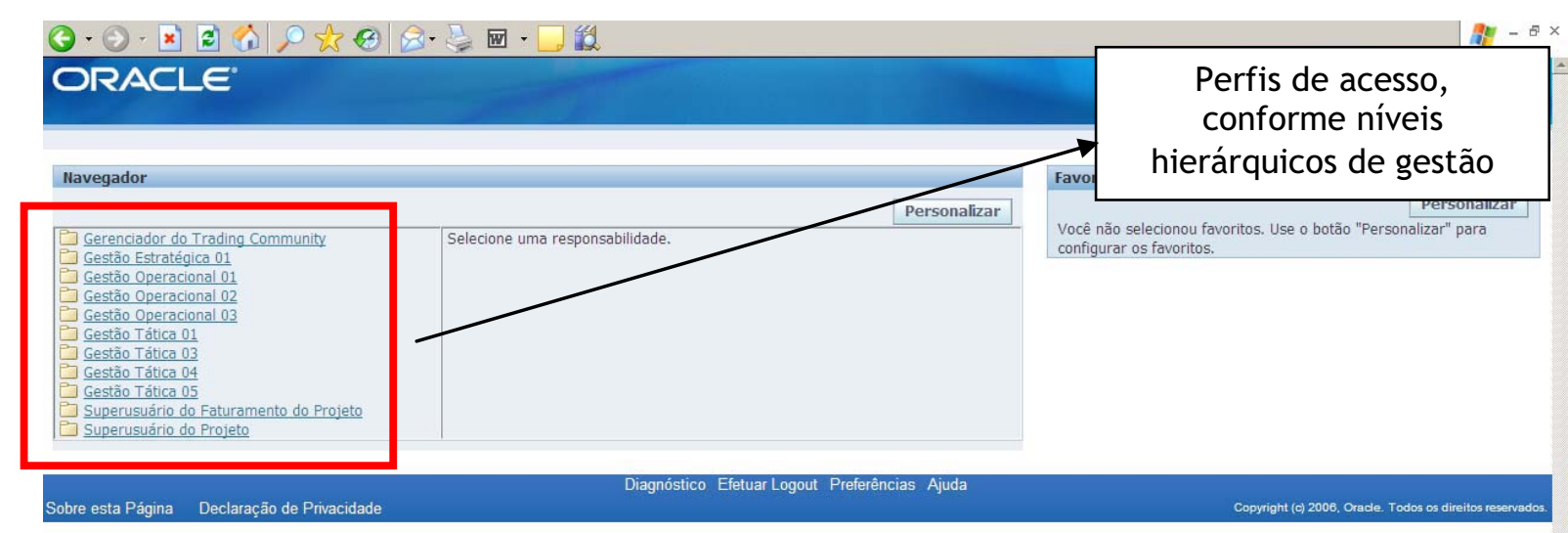

Figura 15 - Tela inicial - níveis de acesso (fonte: ORACLE, 2010) 
- EAP: a organização das tarefas segue a EAP definida para o projeto, de acordo com as suas especificidades, conforme figura 16.

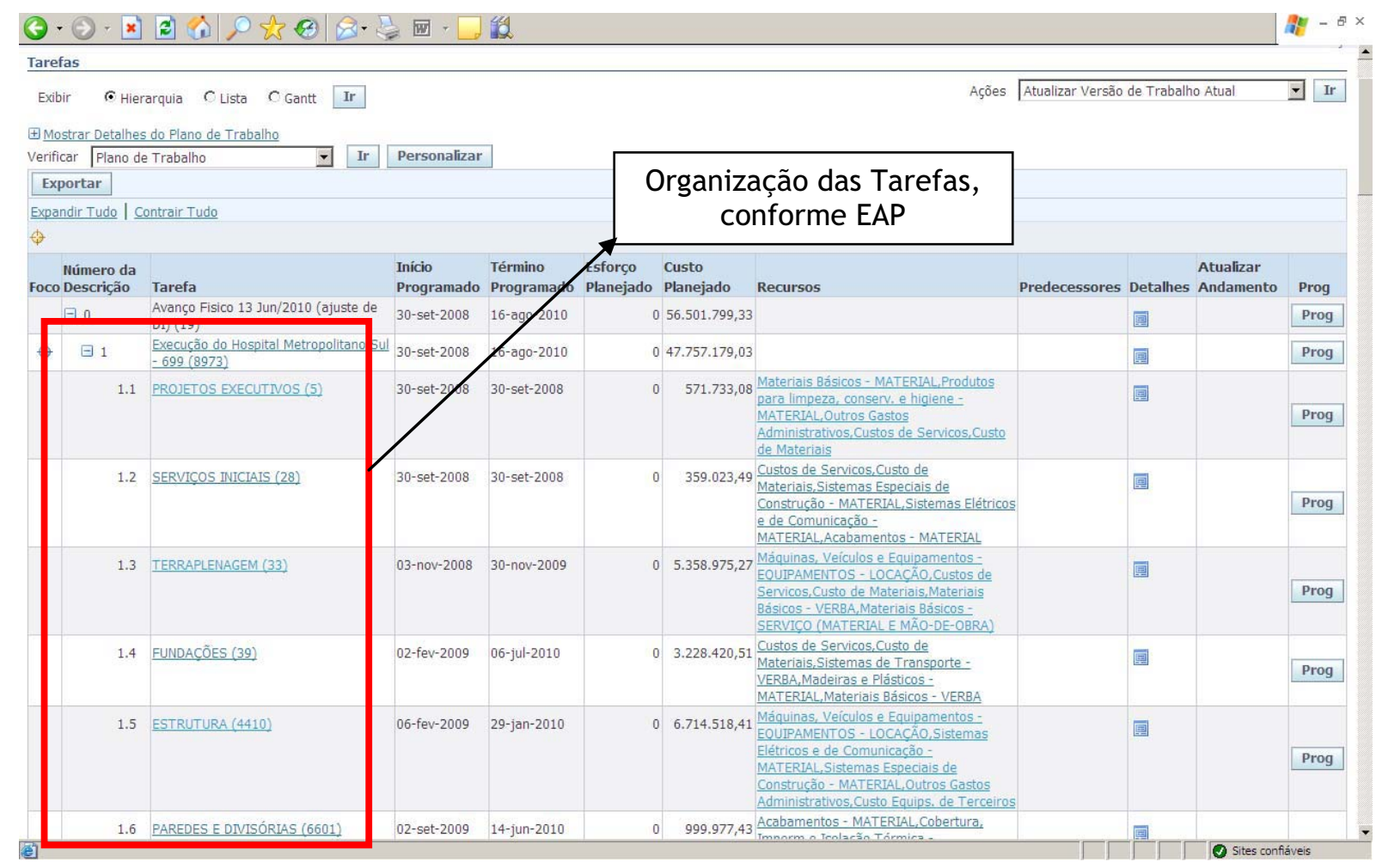

Figura 16 - Tela Plano de Trabalho - Organização das tarefas conforme EAP (fonte: ORACLE, 2010) 
- EAR: na figura 17 é exibida a tela do Plano de Trabalho, sendo os recursos organizados conforme metodologia predefinida pelo gerente do projeto;

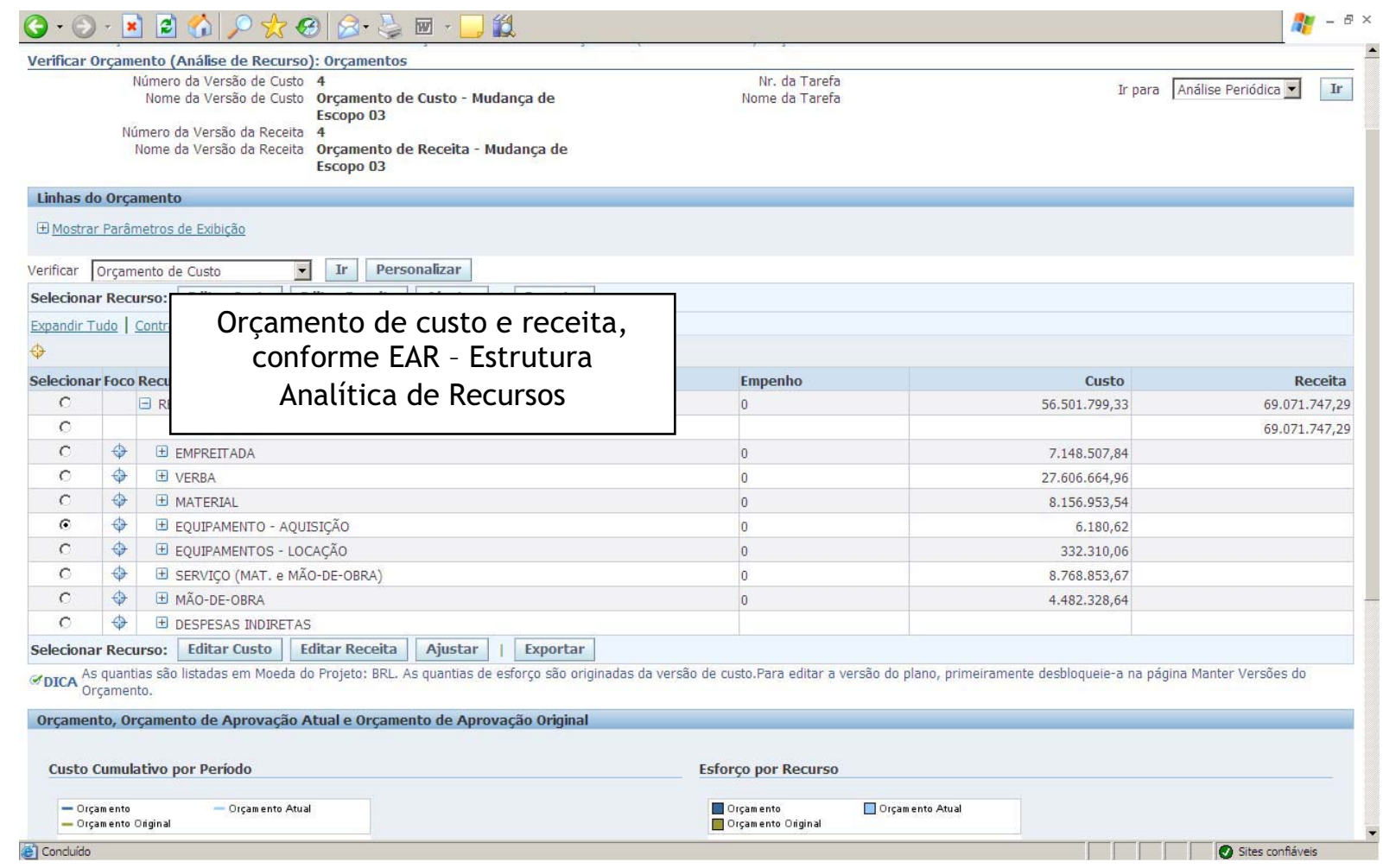

Figura 17 - Tela Plano de Trabalho - Organização das tarefas conforme EAR (fonte: ORACLE, 2010) 
- Cronograma: na figura 18 é exibida a tela do Plano de Trabalho, onde o cronograma do projeto pode ser visualizado pelo Gráfico de Gantt. Pode-se perceber ainda a organização das tarefas conforme método MDP;

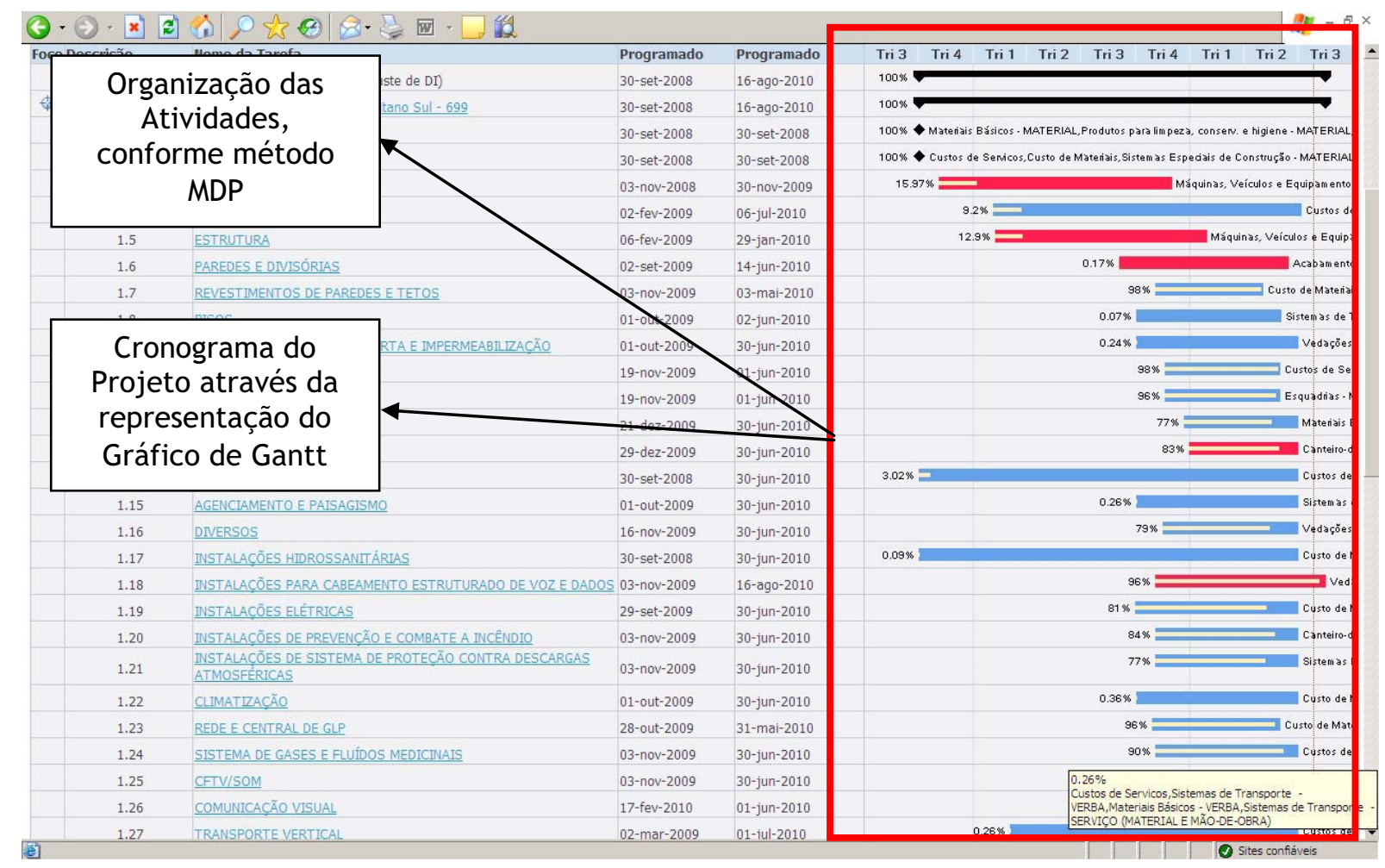

Figura 18 - Tela Plano de Trabalho - Cronograma do projeto (fonte: ORACLE, 2010) 
- Orçamento de Custo: na figura 19 é exibida a tela Financeira, onde o orçamento de custo pode ser visualizado, conforme EAP definida para o projeto. O sistema permite EAP diferenciada para acompanhamento físico e financeiro;

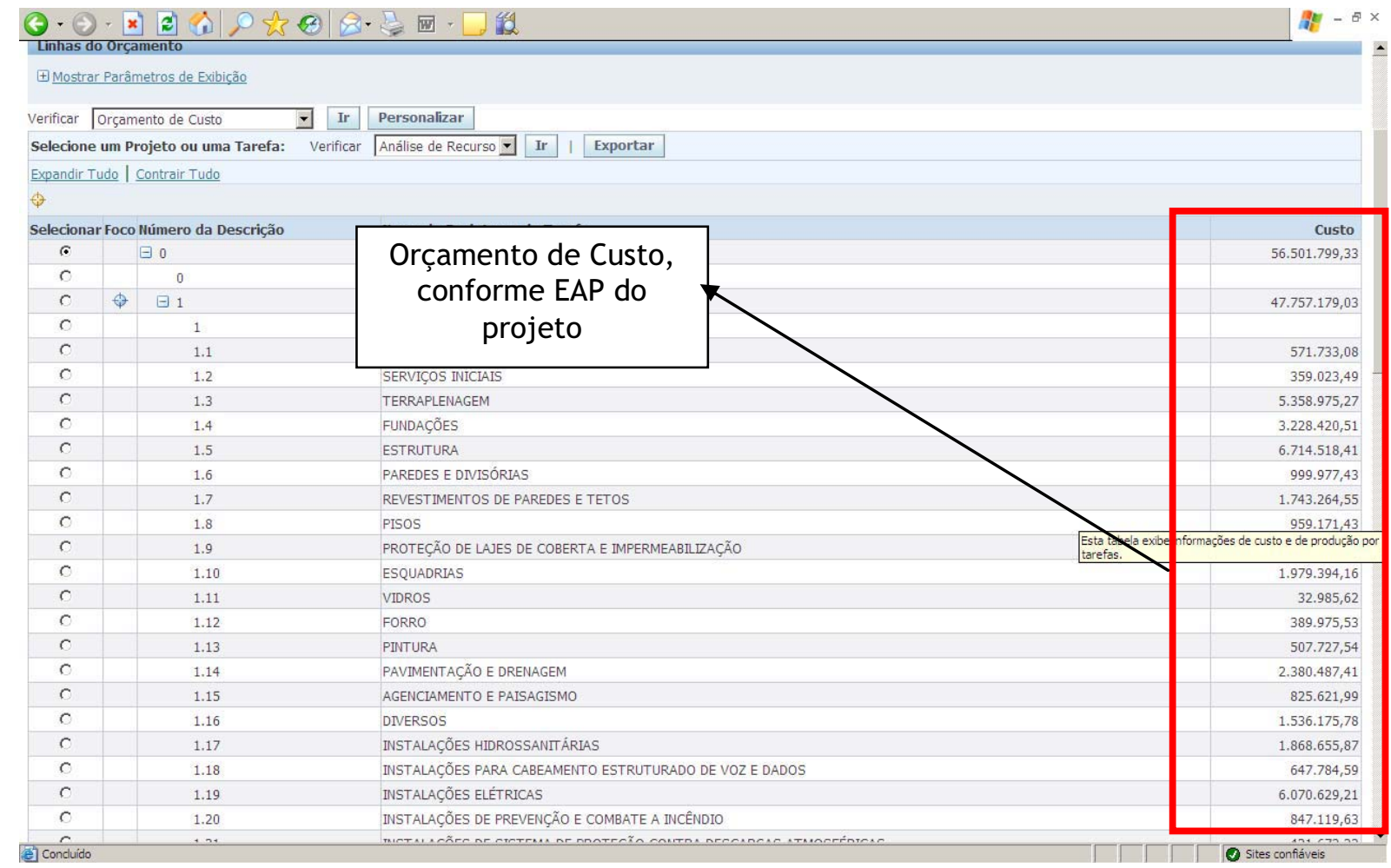

Figura 19 - Tela Financeira - Orçamento de custo do projeto (fonte: ORACLE, 2010) 
- Orçamento de Receita: na figura 20 é exibida a tela Financeira, onde o orçamento de receita pode ser visualizado, conforme EAP predefinida;

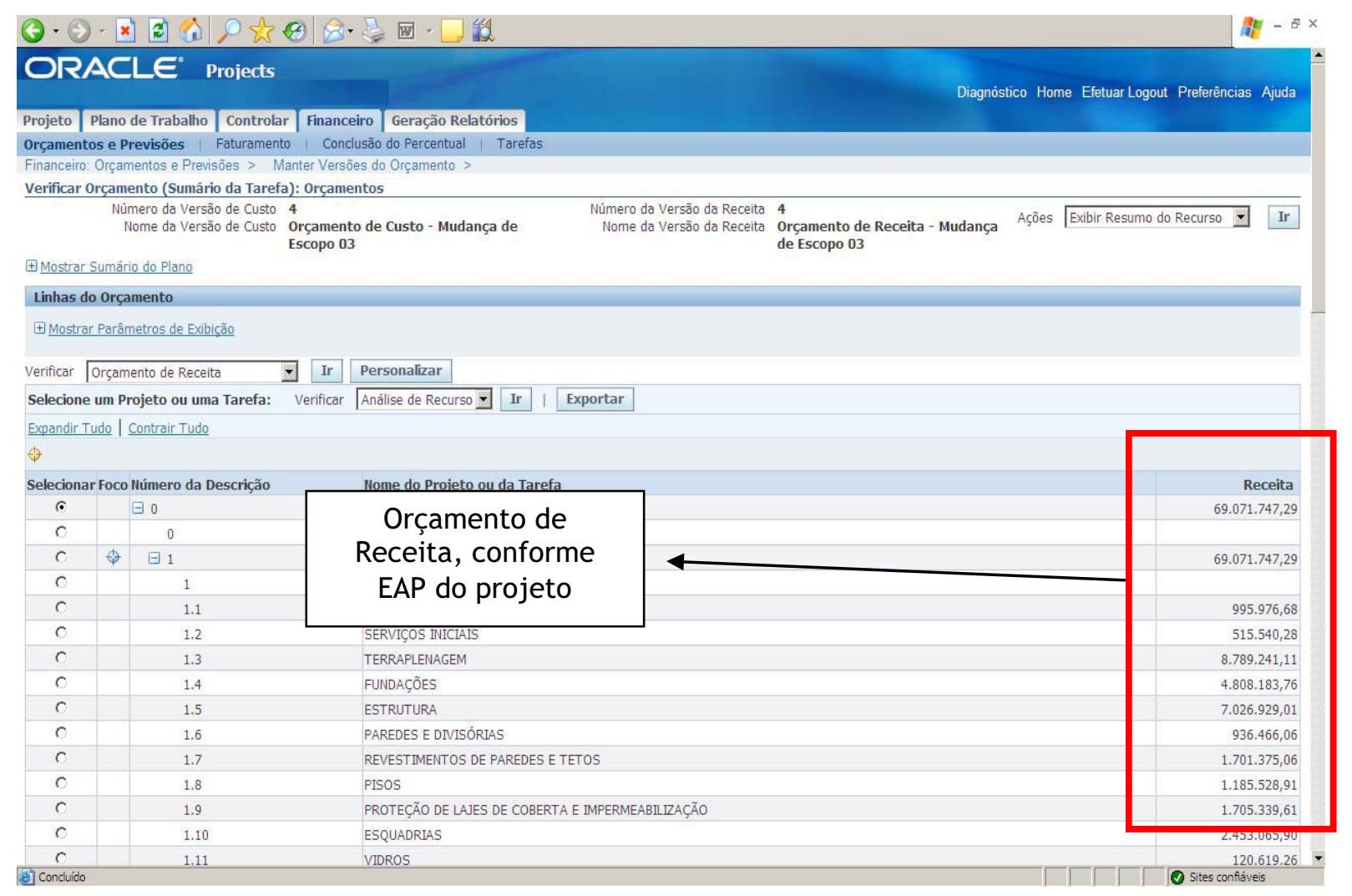

Figura 20 - Tela Financeira - Orçamento de receita do projeto (fonte: ORACLE, 2010) 
- Distribuição do custo e receita: na figura 21 é exibida a tela financeira, onde o orçamento de receita pode ser visualizado, conforme distribuição ao longo dos meses do projeto e, na figura 22, a curva de distribuição que se assemelha à Curva de Gauss.

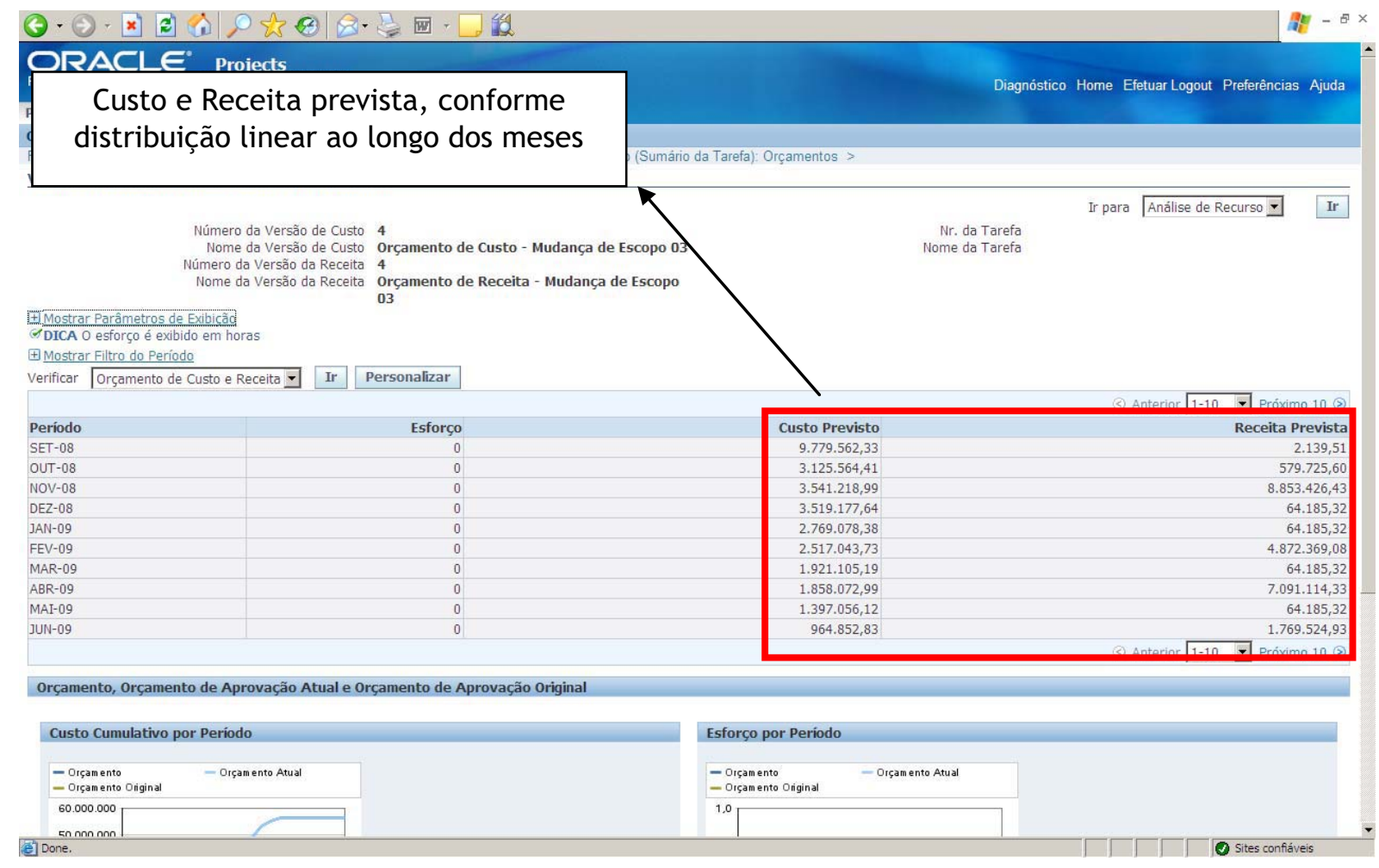

Figura 21 - Tela Financeira - Distribuição do custo e receita do projeto ao longo dos meses (fonte: ORACLE, 2010) 


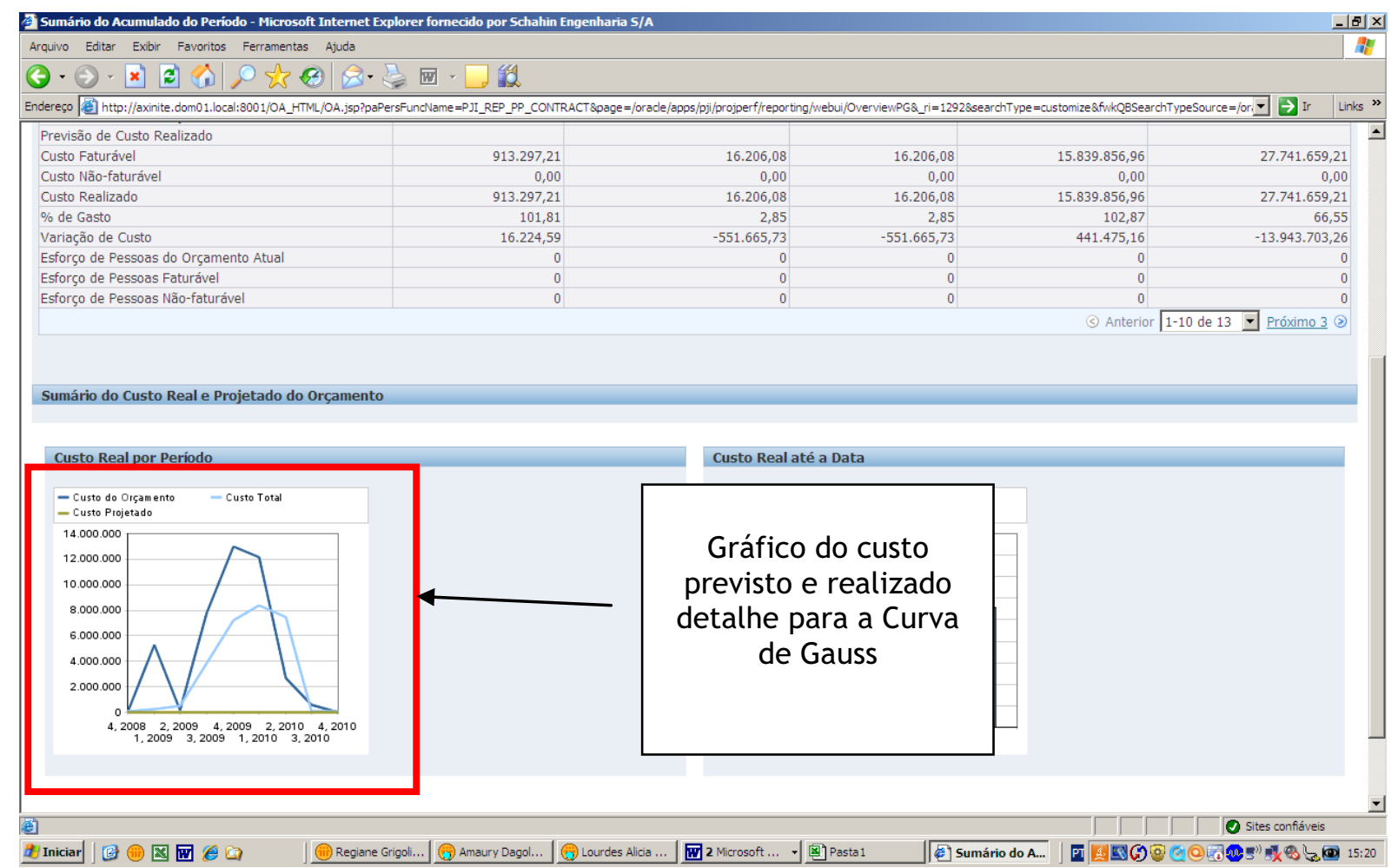

Figura 22 - Tela Financeira - Gráfico da curva de distribuição do custo ao longo dos meses (fonte: ORACLE, 2010) 
- Avanço Físico: na figura 23 é exibida a tela Plano de Trabalho, onde o avanço físico do projeto e tarefas pode ser visualizado, conforme ponderação definida previamente pelo gerente do projeto;

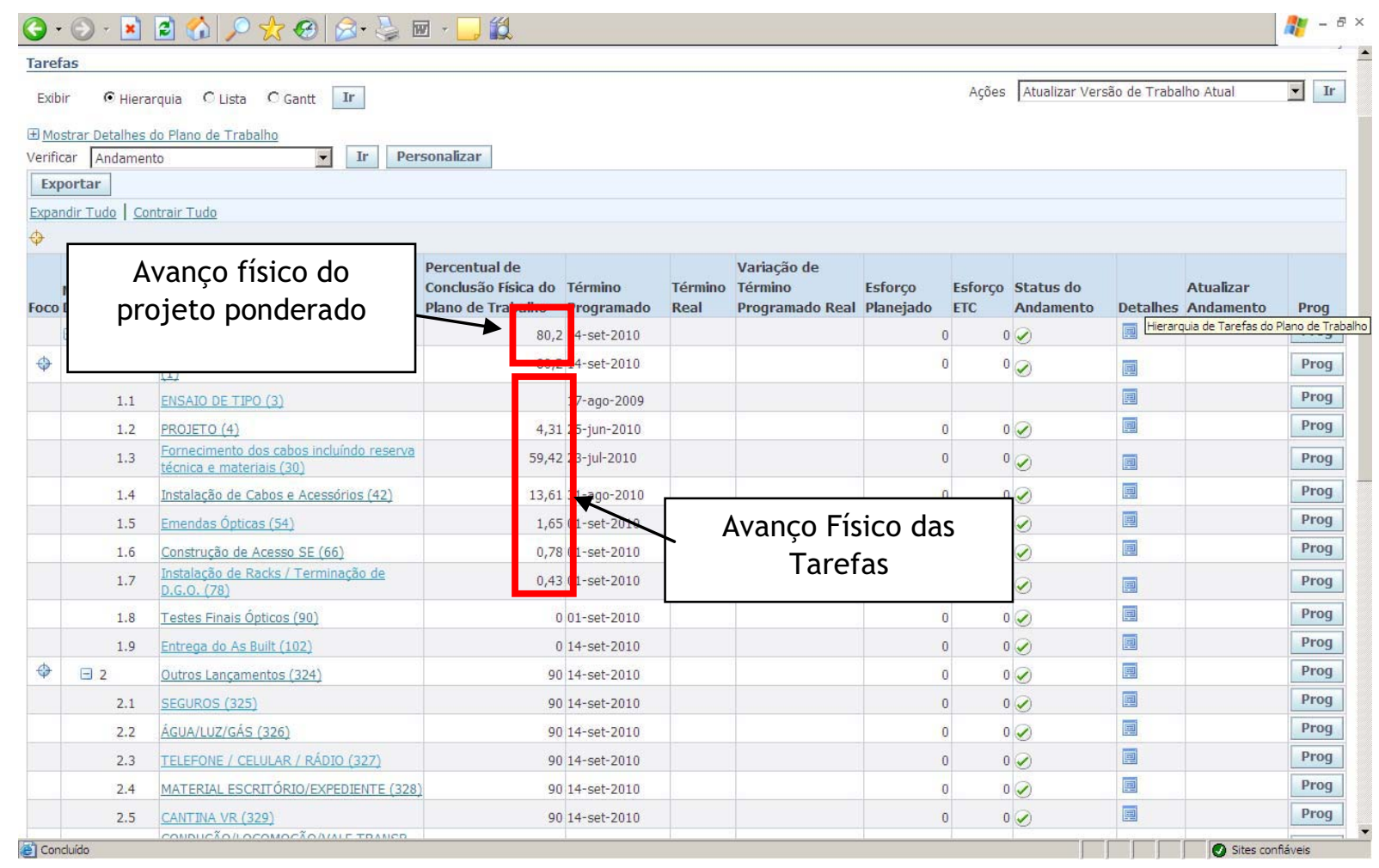

Figura 23 - Tela Plano de Trabalho - Avanço físico do projeto

(Fonte: ORACLE, 2010) 
- Indicadores de desempenho: na figura 24 é exibida a tela Geração de Relatórios, que exibe as informações consolidadas do projeto, dentre elas, os indicadores de desempenho, como IDA, IDAC e IDC;

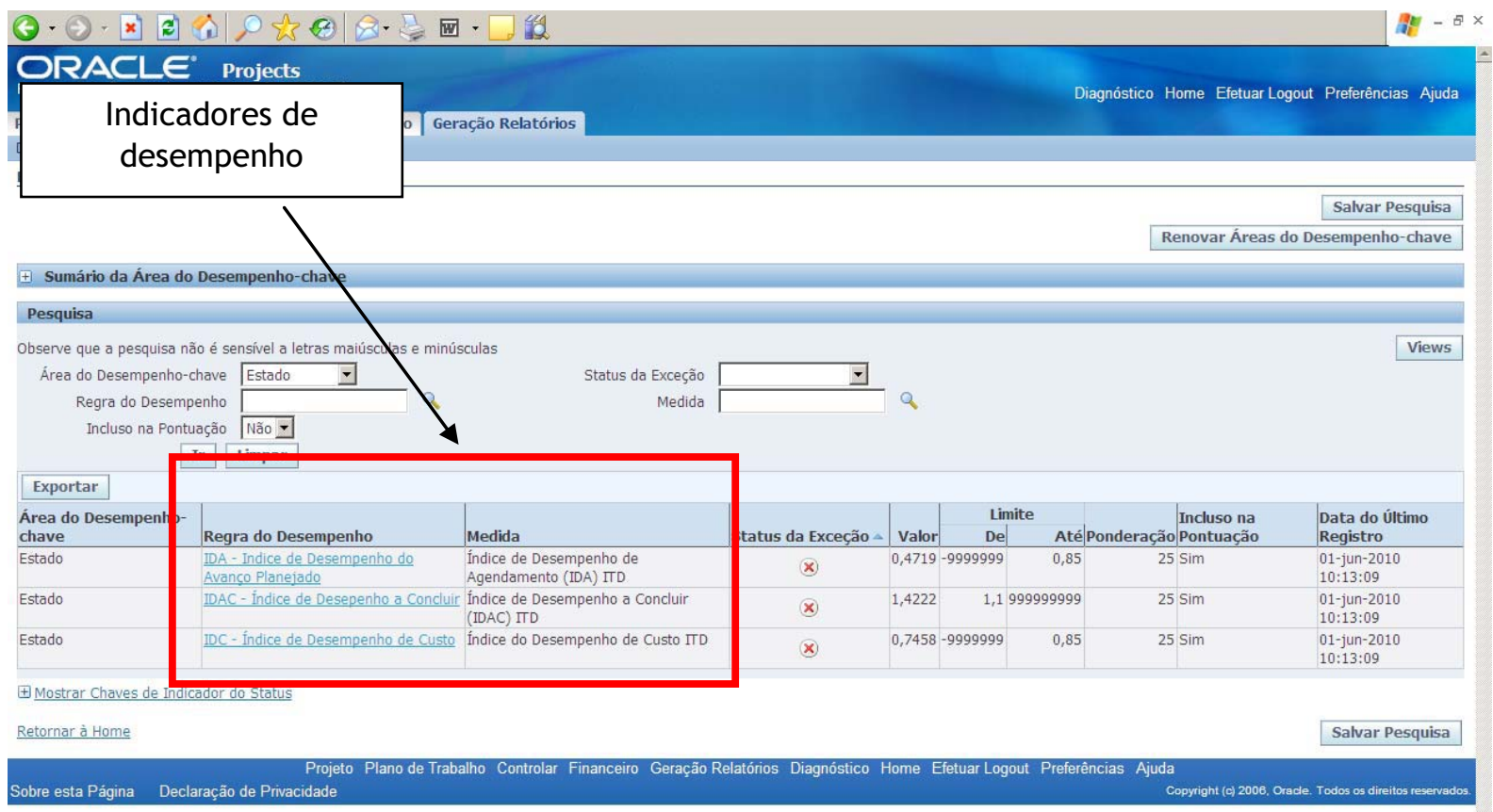

Figura 24 - Tela Geração de Relatórios - Indicadores de desempenho do projeto (Fonte: ORACLE, 2010) 
- Disciplina, organização e rastreabilidade: na figura 25 é exibida a tela Plano de Trabalho, onde podem ser exibidas as informações históricas de avanço físico da obra, com os respectivos usuários responsáveis, data e hora da publicação;

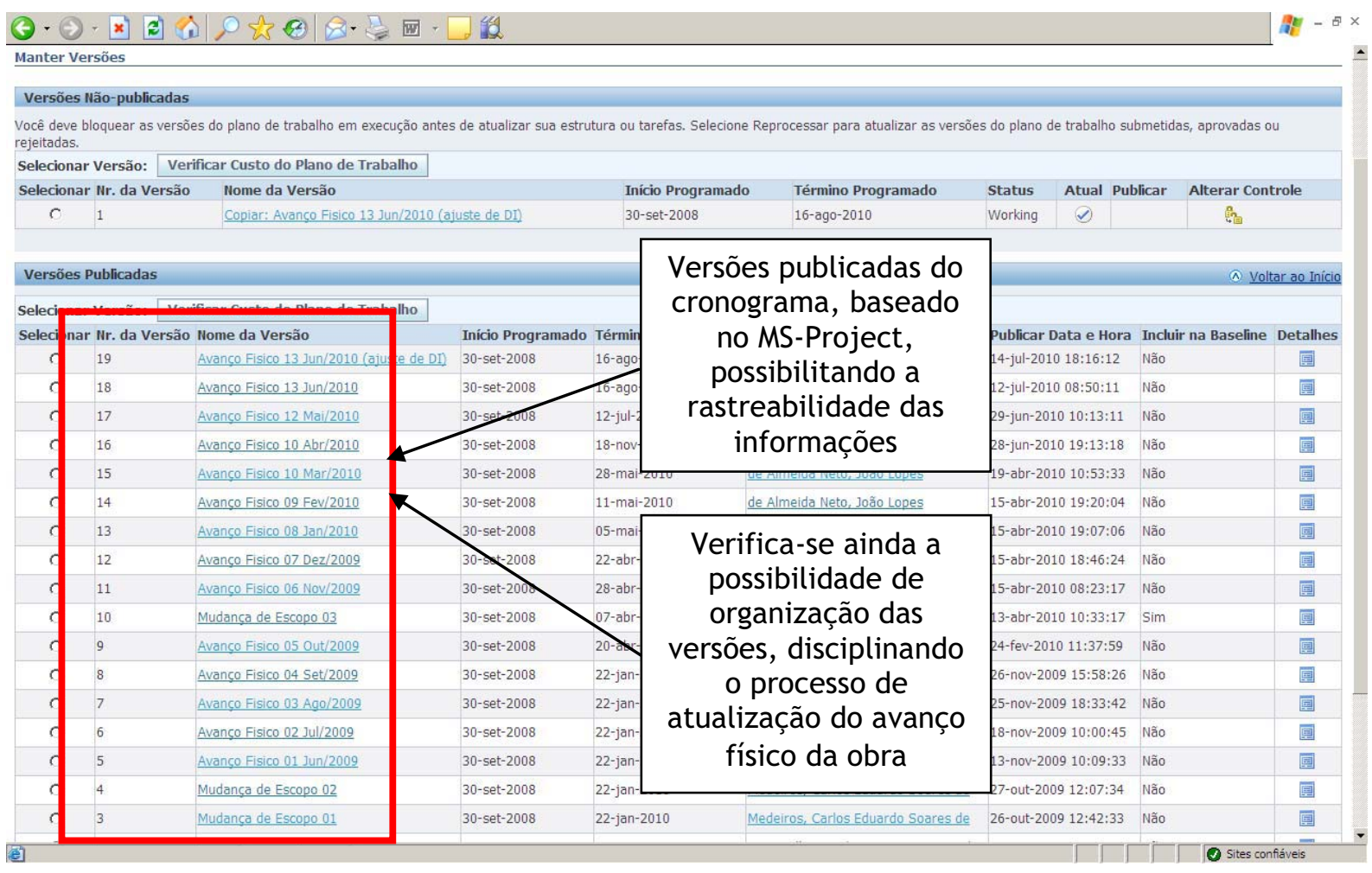

Figura 25 - Tela Plano de Trabalho - Organização das versões publicadas (Fonte: ORACLE, 2010)

Com base nas figuras apresentadas, verifica-se que o sistema EBS está alinhado às práticas para gestão de projetos relatadas no capítulo 3, além de se tratar de uma ferramenta que permite o gerenciamento dos projetos e portfólios de forma sistêmica. 
"O conhecimento torna a alma jovem e diminui a amargura da velhice, colhe pois, a sabedoria. Armazena a suavidade para o amanhã"

Leonardo da vinci

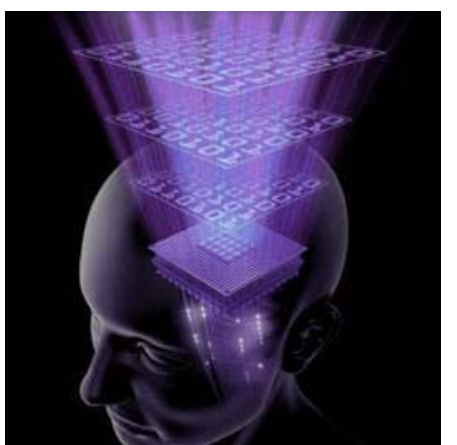




\section{Estudos de caso}

Neste capítulo será abordada, inicialmente, a metodologia utilizada para estudos de caso, como o processo de seleção das empresas e o método de pesquisa. Posteriormente, serão identificados os três estudos de caso sendo caracterizadas as empresas pelo seu porte ${ }^{37} \mathrm{e}$ área de atuação.

Ainda, nos estudos de casos, serão apresentados o cronograma, funções e responsabilidades dos profissionais envolvidos na implementação, bem como a estratégia da empresa na implementação do sistema.

A partir do embasamento teórico, obtido nos capítulos anteriores é possível analisar a utilização do sistema nos níveis de gestão, macroprocessos da empresa e, com os critérios estabelecidos na implementação da ferramenta, é possível verificar a aplicabilidade das práticas de gestão nos processos da empresa.

Por fim, são relacionadas as dificuldades enfrentadas pelos envolvidos no processo de implementação e as limitações da ferramenta para a gestão de contratos.

\subsection{Metodologia utilizada para estudos de caso}

Os estudos de caso buscam apresentar, segundo Tachizawa e Mendes (2006), por meio de elementos obtidos diretamente na pesquisa de campo, informações primárias e essenciais para que se possa alcançar o objetivo principal do trabalho.

\footnotetext{
${ }^{37}$ Classificação do porte das construtoras, conforme a Comissão de Economia e Estatística da CBIC - Câmara Brasileira da Indústria da Construção (2003):

- Pequeno Porte: até 29 funcionários

- Médio Porte: de 30 até 499 funcionários

- Grande Porte: mais de 500 funcionários
} 
Além disso, Tachizawa e Mendes (2006) ressaltam que os estudos de caso devem ser desenvolvidos a partir de análises em determinadas organizações.

Segundo Yin (2009), o processo para elaboração de um estudo de caso deve passar pelas seguintes atividades principais:

- Planejamento da pesquisa;

- Elaboração do escopo;

- Preparação (questionários, roteiros de pesquisa e etc.);

- Coleta de dados;

- Análise dos dados;

- Organização dos dados.

Conforme a Figura 26, o processo de pesquisa de um estudo de caso é linear e interativo.

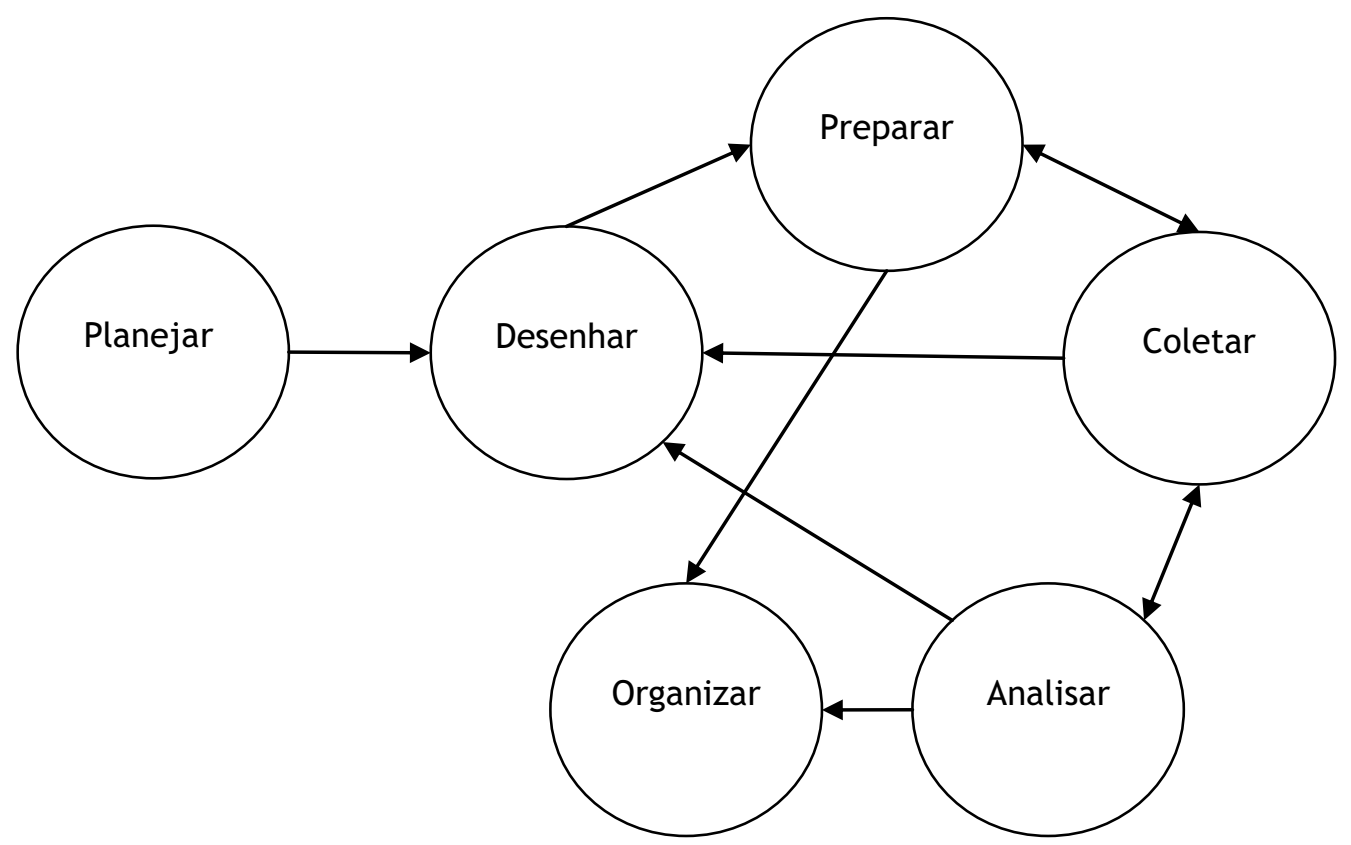

Fonte: adaptação de YIN, 2009

Figura 26- Processo para fazer uma pesquisa de estudo de caso 
Com base nisso e no objetivo do trabalho, definiu-se que seria necessário estudar a implementação de sistema integrado de gestão de contratos, tomando como referência o levantamento de dados em empresas construtoras.

Para a seleção das construtoras, inicialmente foram realizadas entrevistas com profissionais de empresas implementadoras, que indicaram aquelas que implantaram a ferramenta ou que estavam em fase de implementação.

De posse dos contatos das empresas, foi possível identificar as que melhor se enquadrariam nos estudos de caso, optando-se por aquelas cuja implementação tivesse sido recente.

Nesse processo, foi selecionada a construtora A, por ser de grande porte, com atuação em várias setores como: engenharia, desenvolvimento imobiliário, telecomunicações, petróleo e gás, energia e finanças (banco, corretora e financeira).

$\mathrm{Na}$ sequência, foi escolhida a construtora $\mathrm{B}$, de médio porte, passando atualmente por processos de melhoria contínua, especificamente na área de gestão de projetos, em que certificou mais de 45 profissionais pelo PMI (Project Management Institute).

$E$, por fim a construtora $C$, também de médio porte e encontra-se entre as 20 maiores construtoras do país (O EMPREITEIRO, 2010).

Após a seleção das construtoras, foi realizado um roteiro, que permitiu um estudo exploratório da empresa, por meio de entrevistas com os envolvidos no processo de implementação. Nesse roteiro, foram abordados os seguintes assuntos:

- caracterização da empresa;

- estratégia para implementação do sistema;

- cronograma de implementação; 
- funções e responsabilidades dos envolvidos;

- estratégia para capacitação dos profissionais envolvidos no sistema de gestão de contratos;

- elaboração/organização dos dados a serem implantados no sistema;

- carga e manutenção dos dados do sistema, como cronograma da obra, custos e receitas orçadas;

- controle físico e financeiro do projeto;

- dificuldades enfrentadas pelos envolvidos no processo;

- limitações da ferramenta para gestão de contratos.

Com base nisso, foram mapeados os processos de implementação da ferramenta, os profissionais envolvidos nos diversos níveis de gestão, a estratégia de implementação, bem como cronogramas, principais dificuldades e benefícios da implementação.

\subsection{Estudo de Caso 1}

\subsubsection{Caracterização da construtora A}

A construtora A está presente no mercado há mais de quatro décadas e hoje é um grupo sólido e diversificado, com atuação nos principais setores de desenvolvimento do país: engenharia, desenvolvimento imobiliário, telecomunicações, petróleo e gás, energia e finanças (banco, corretora e financeira).

A empresa foi fundada em 1976, iniciando sua atuação nas áreas de empreendimentos imobiliários e engenharia e construção. 
Em 1982, a construtora ingressou no setor de petróleo e, em 1986, no setor de energia.

Impulsionada pelo “boom” das telecomunicações, em 1992, a empresa passou a atuar nesse setor.

Atualmente, a construtora possui mais de três mil colaboradores, já construiu mais de 5 milhões de $\mathrm{m}^{2}$, ao longo dos seus 40 anos de atuação, e hoje possui 22 obras em andamento.

De acordo com a Revista Exame (2010), a construtora está entre as 1.000 maiores empresas do Brasil.

A empresa encontra-se entre as 25 maiores construtoras do Brasil, com faturamento em torno de 600 milhões de Reais (O EMPREITEIRO, 2010).

\subsubsection{Estratégia de implementação}

A implementação do sistema na empresa foi gradativa e dividida em duas fases bem definidas. A primeira (Fase 1) referiu-se ao levantamento dos processos da empresa, configurações, testes, homologação e treinamento e implementação na obra piloto. A segunda (Fase 2) compreendeu a implementação do sistema de gestão nas obras e departamentos afins, após treinamentos das equipes das respectivas obras.

\section{a. Fase 1}

A fase 1 compreendeu, basicamente, os trabalhos preliminares para a implementação do sistema de gestão de contratos, sendo necessário para isso efetuar o levantamento das necessidades e dos processos atuais da empresa. 
Após essas definições, partiu-se para as configurações na ferramenta e, posteriormente, à realização de testes em projetos fictícios, em que eram apontados os erros e realizadas as correções necessárias. Caso estivessem relacionados às configurações, estas eram reconfiguradas. No entanto, se fossem erros de sistema, estes eram encaminhados para a empresa desenvolvedora.

Os erros eram classificados em impeditivos para Go-live ${ }^{38}$ e não impeditivos. Dessa forma, os erros impeditivos eram tratados urgentemente, pois impactavam diretamente o cronograma de implementação. Os não impeditivos eram considerados com menor peso.

Finalizada a etapa de testes, partiu-se para a homologação, que consiste na apresentação, para os colaboradores envolvidos, dos processos dentro do sistema. Os profissionais envolvidos deveriam fazer os testes necessários para aprovar a implementação do processo na ferramenta.

$\mathrm{Na}$ homologação, foram envolvidas as seguintes áreas da empresa, conforme o processo:

- Suprimentos - processo de compras

- Planejamento e controle - processo de planejamento e controle das obras (planejamento físico, planejamento financeiro, gestão física, gestão financeira e desempenho geral do projeto)

- Faturamento - receita prevista e realizada

- Contabilidade - lançamentos realizados

- Obra - atualização dos dados do projeto

Cabe ressaltar que, nessa fase, nem todos os erros não impeditivos foram sanados, partindo-se para a fase seguinte sem ter resolvido todos os problemas, já que alguns dependiam da resolução da empresa desenvolvedora ${ }^{39}$.

\footnotetext{
${ }^{38}$ Go-live: termo comumente utilizado na área de TI, e significa "colocar no ar".

${ }^{39}$ Empresa desenvolvedora: Oracle.
} 


\section{b. Fase 2}

A fase 2 ocorreu de forma faseada, ou seja, optou-se por implementar gradativamente o sistema, obra por obra e departamento por departamento.

Na Figura 27, é apresentado o cronograma faseado de implementação que se subdividiu nas seguintes tarefas principais:

- implantação dos dados

- treinamento

- visitas

\begin{tabular}{|c|c|c|c|c|c|c|c|c|c|c|c|c|}
\hline \multirow{3}{*}{ Relação das Obras e Atividades } & \multicolumn{12}{|c|}{2009} \\
\hline & \multicolumn{4}{|c|}{ Agosto } & \multicolumn{4}{|c|}{ Setembro } & \multicolumn{4}{|c|}{ Outubro } \\
\hline & $\begin{array}{c}\text { Sem } \\
1\end{array}$ & $\begin{array}{c}\text { Sem } \\
2\end{array}$ & $\begin{array}{c}\text { Sem } \\
3\end{array}$ & $\begin{array}{c}\text { Sem } \\
4\end{array}$ & $\begin{array}{c}\text { Sem } \\
1\end{array}$ & $\begin{array}{c}\text { Sem } \\
2\end{array}$ & $\begin{array}{c}\mathrm{Sem} \\
3\end{array}$ & $\begin{array}{c}\text { Sem } \\
4\end{array}$ & $\begin{array}{c}\text { Sem } \\
1\end{array}$ & $\begin{array}{c}\text { Sem } \\
2\end{array}$ & $\begin{array}{c}\text { Sem } \\
3\end{array}$ & $\begin{array}{c}\text { Sem } \\
4\end{array}$ \\
\hline \multicolumn{13}{|l|}{ OBRA 01 } \\
\hline \multicolumn{13}{|l|}{ Implantação dos dados } \\
\hline \multicolumn{13}{|l|}{ Treinamento } \\
\hline Visitas & & & & & & & & $t$ & & $t$ & & \\
\hline \multicolumn{13}{|l|}{ OBRA 02} \\
\hline \multicolumn{13}{|l|}{ Implantação dos dados } \\
\hline \multicolumn{13}{|l|}{ Treinamento } \\
\hline Visitas & & & & & & & & t & & + & & \\
\hline \multicolumn{13}{|l|}{ OBRA 03} \\
\hline \multicolumn{13}{|l|}{ Implantação dos dados } \\
\hline \multirow{2}{*}{\multicolumn{13}{|c|}{$\begin{array}{l}\text { Treinamento } \\
\text { Visitas }\end{array}$}} \\
\hline & & & & & & & & $t$ & & $t$ & & \\
\hline \multicolumn{13}{|l|}{ OBRA 04} \\
\hline \multirow{2}{*}{\multicolumn{13}{|c|}{ Implantação dos dados }} \\
\hline \multirow{2}{*}{\multicolumn{13}{|c|}{$\begin{array}{l}\text { Treinamento } \\
\text { Visitas }\end{array}$}} \\
\hline & & & & & & & & & & & & \\
\hline \multicolumn{13}{|l|}{ OBRA 05} \\
\hline \multicolumn{13}{|l|}{$\begin{array}{l}\text { Implantação dos dados } \\
\text { Treinamento }\end{array}$} \\
\hline Treinamento & & & & & & & & & & & & \\
\hline \multicolumn{13}{|l|}{ Visitas } \\
\hline \multicolumn{13}{|l|}{ OBRA 06} \\
\hline \multirow{2}{*}{\multicolumn{13}{|c|}{$\begin{array}{l}\text { Implantação dos dados } \\
\text { Treinamento }\end{array}$}} \\
\hline & & & & & & & & & & & & \\
\hline \multicolumn{13}{|l|}{ Visitas } \\
\hline & & & & & & & & & Legen & & & \\
\hline & & & & & & & & 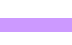 & Implan & tação o & los dac & los \\
\hline & & & & & & & & & Treina & mento & & \\
\hline
\end{tabular}

Figura 27 - Exemplo de cronograma faseado

- Implantação dos dados: compreende a tarefa de carregar dados na ferramenta para a atualização posterior pela obra. Geralmente, são colocadas as seguintes informações: 
- cronograma inicial da obra, elaborado na fase de proposta;

- orçamento de custo, elaborado na fase de proposta;

- orçamento de venda, elaborado na fase de proposta.

Além disso, nessa tarefa, são liberados os acessos à equipe do projeto, conforme as funções e responsabilidades de cada membro da equipe.

- Treinamento: essa tarefa compreendeu habilitar os membros do projeto na utilização do sistema. Estiveram envolvidos, nessa atividade, apenas os profissionais que teriam acesso à ferramenta e, além do sistema de gestão, os membros do projeto também receberam treinamento de ferramentas de apoio, como:

○ treinamento avançado do MS-Project;

0 treinamento da ferramenta de back-office ${ }^{40}$.

Foram realizados treinamentos obra por obra, envolvendo os profissionais da área administrativa, planejamento e produção da obra. Para isso, foram alugadas salas nas cidades das obras e a equipe de key-users ${ }^{41}$ ministrava os treinamentos.

Em cada obra, foram habilitados cerca de 10 profissionais e o treinamento, com carga horária de 24 horas, ocorreu conforme a grade apresentada no Quadro 19.

${ }^{40}$ Back-office: sistema de apoio administrativo, financeiro e contábil (ERP).

${ }^{41}$ Key-user: usuário chave que domina todos os processos da ferramenta ou de módulos completos. 


\begin{tabular}{|c|c|c|}
\hline Ferramenta & Assuntos abordados no treinamento & Carga horária (horas) \\
\hline $\begin{array}{l}\text { MS-Project } \\
\text { Avançado }\end{array}$ & $\begin{array}{l}\text { - Avanço físico por quantidade } \\
\text { - Ponderação do cronograma por custo ou Hh }\end{array}$ & 6 \\
\hline Back-office & $\begin{array}{l}\text { - Cadastro de itens } \\
\text { - Navegação no JDE }\end{array}$ & 3 \\
\hline Sistema de Gestão de Contratos & $\begin{array}{l}\text { - Introdução ao Sistema de Gestão de Contratos } \\
\text { - Navegação no Sistema de Gestão de Contratos } \\
\text { - Características do Projeto } \\
\text { - Plano de Trabalho } \\
\text { - Programação de Compras }\end{array}$ & 3 \\
\hline $\begin{array}{c}\text { Intregração entre } \\
\text { Back-office } \\
\text { e } \\
\text { Sistema de Gestão de Contratos }\end{array}$ & $\begin{array}{l}\text { - Exercícios de programação de compras } \\
\text { - Processos de suprimentos }\end{array}$ & 3 \\
\hline Sistema de Gestão de Contratos & $\begin{array}{l}\text { - Atualização do Cronograma } \\
\text { - Atualização do Avanço físico }\end{array}$ & 3 \\
\hline Sistema de Gestão de Contratos & $\begin{array}{l}\text { - Gestão Financeiro } \\
\text { - Indicadores de desempenho do contrato } \\
\text { - Geração de Relatórios no Sistema de Gestão de } \\
\text { Contratos }\end{array}$ & 3 \\
\hline Back-office & $\begin{array}{l}\text { - Relatórios do Sistema Back-office } \\
\text { - Realocação dos custos incorridos }\end{array}$ & 3 \\
\hline \multicolumn{2}{|c|}{ CARGA HORÁRIA TOTAL } & 24 \\
\hline
\end{tabular}

Quadro 19 - Carga horária dos treinamentos - Empresa A

- Visitas técnicas: foram realizadas pela equipe de implementação e tinham por finalidade verificar a aderência da ferramenta nas atividades da obra. Além disso, nessa tarefa, eram sanadas dúvidas e revisados alguns procedimentos dados em treinamentos. 


\subsubsection{Cronograma de implementação}

A implementação do sistema de gestão de contratos iniciou-se em setembro de 2008 e finalizou-se em dezembro de 2010, totalizando 28 meses, conforme Figura 28.

Nesse período, pode-se separar a implementação nas seguintes fases principais:

FASE 1 - a duração inicial estava estimada em cinco meses, porém ocorreu efetivamente no período de setembro de 2008 até setembro de 2009, ou seja, oito meses de atraso em relação ao prazo inicial estimado.

FASE 2 - a duração inicial era de nove meses, porém está prevista para ser concluída em 14 meses, entre os períodos de outubro de 2009 até dezembro/2010.

EMPRESA A

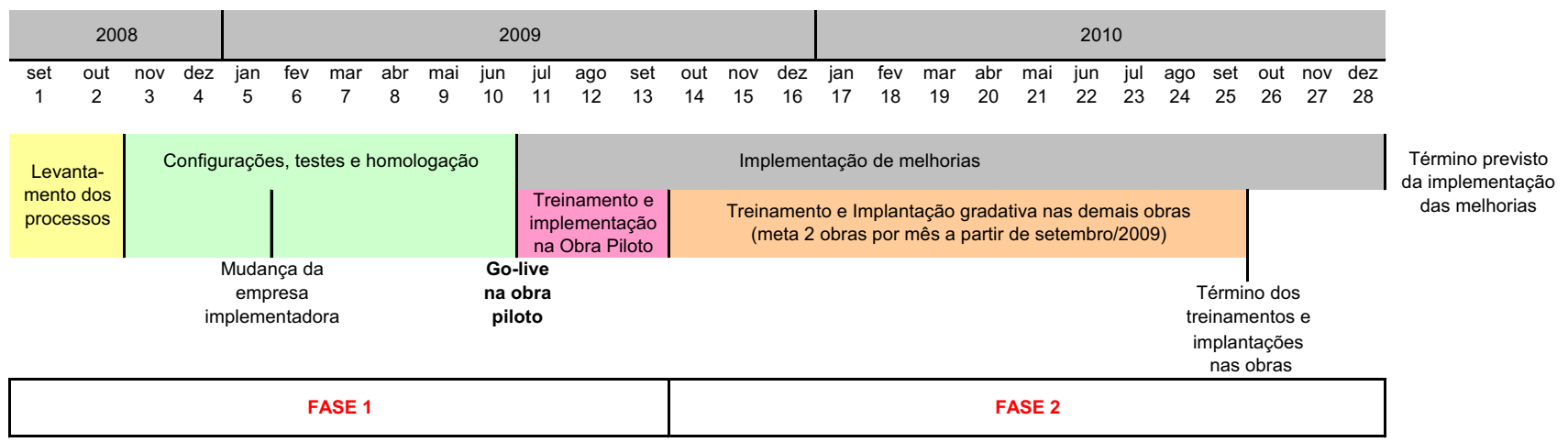

Figura 28 - Cronograma de implementação do sistema - Empresa A

Vale a pena ressaltar que, inicialmente, a Fase 1 estava prevista para ser finalizada em Fevereiro/2009, entretanto, devido ao atraso nas atividades de implementação, a empresa consultora contratada foi mudada e o cronograma estendido por mais quatro meses. 
A Fase 2 foi finalizada em Junho/2010, após o re-planejamento do cronograma, ocorrido com o atraso na Fase $1 \mathrm{e}$, devido ao número de melhorias a serem realizadas, a atividade foi atrasada por mais seis meses.

\subsubsection{Funções e responsabilidades dos profissionais envolvidos}

Para qualificar a equipe de profissionais envolvidos na implementação a empresa contratou consultoria na área de gestão de projetos, que ministrou um treinamento com carga horária de 24 horas. 0 treinamento tinha como objetivo principal habilitar os profissionais nas práticas de gestão de contratos.

Com relação às funções e às responsabilidades da equipe, como a implementação foi dividida em duas fases distintas, como explanado no tópico 5.2.2 Estratégia de implementação, as funções e as responsabilidades foram diferentes para as duas fases, conforme descrito, a seguir:

Funções e responsabilidades da equipe de implementação - Fase 1: a equipe da fase 1 era composta por 24 profissionais, conforme organograma de implementação do projeto apresentado na figura 29. Ressalta-se que, dos 24 profissionais, 14 se dedicaram exclusivamente à implementação do sistema. 


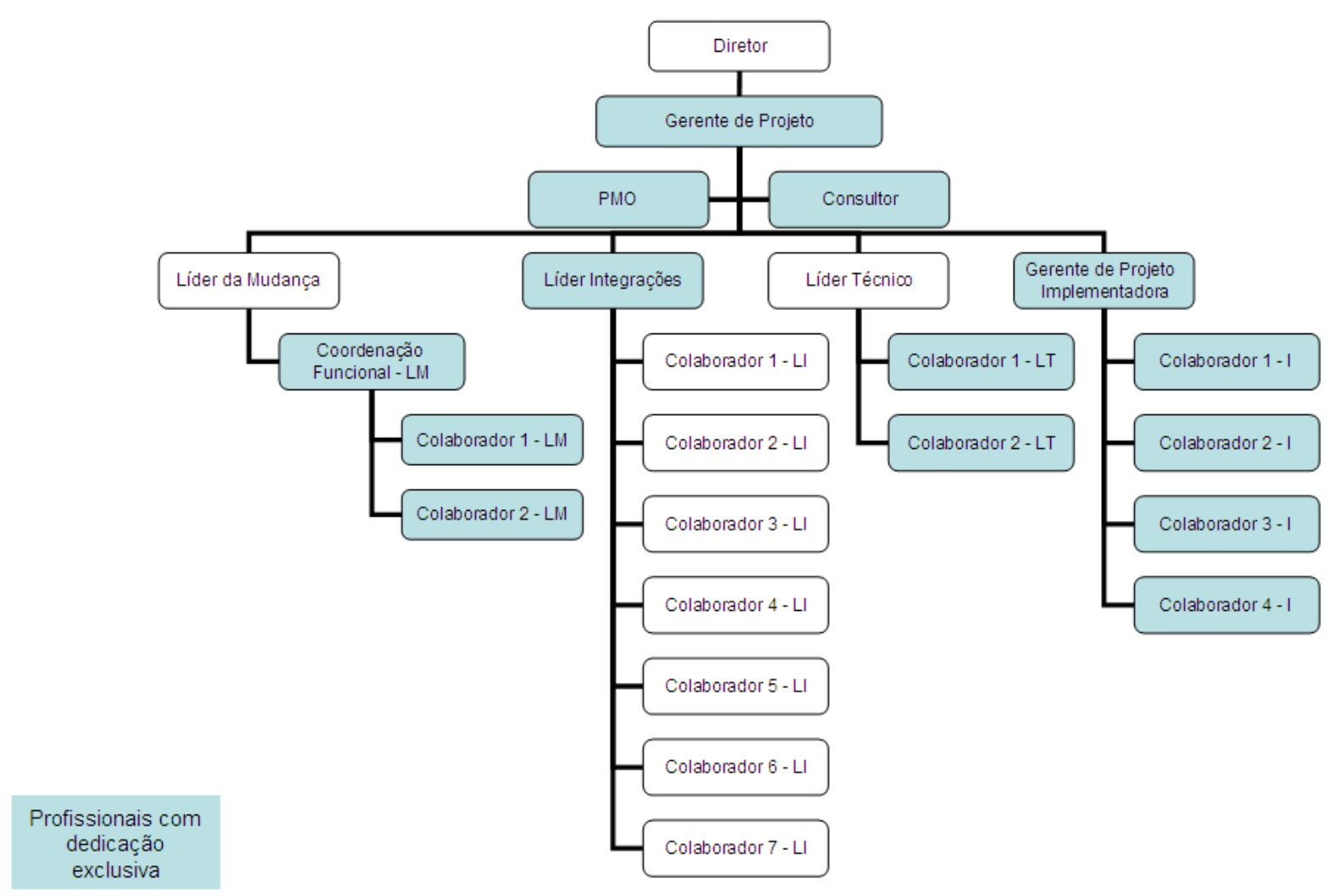

Figura 29 - Organograma da equipe de implementação do sistema - Empresa A

Líder da Mudança: responsável pelo acompanhamento do processo de mudança

Líder das Integrações: responsável pela integração entre o sistema de gestão e o back-office da empresa

Líder técnico: responsável pela parte técnica (servidores, banco de dados, etc.)

Gerente de projeto da implementadora: acompanhamento do processo de implementação

Como as funções e as responsabilidades da Fase 1 estão relacionadas com tarefas de configuração, tanto de hardware como softwares, testes e homologação, tiveram grande envolvimento da equipe de $\mathrm{TI}$. 
Funções e responsabilidades da equipe de implementação - Fase 2: a equipe é composta por seis profissionais, dedicados exclusivamente à implementação da ferramenta nas obras e departamentos. Como as tarefas estão relacionadas à carga de dados das obras, treinamentos e visitas técnicas, todos os profissionais são da área técnica (construção civil), conforme quadro 20.

\begin{tabular}{|c|c|c|c|}
\hline Quantidade & Cargo & Profissão & Responsabilidade \\
\hline 1 & Gerente de Planejamento e Controle & Engenheiro Civil & $\begin{array}{l}\text { Gerenciar toda a implantação nas obras e departamentos afins, } \\
\text { garantindo a transição das atividades para a ferramenta de gestão. } \\
\text { Esta função é comumente chamada pelos profissionais de TI como } \\
\text { "Líder da Mudança" }\end{array}$ \\
\hline 1 & Coordenadora de TI & Engenheiro Civil & $\begin{array}{l}\text { Treinamento dos membros do projeto e coordenação das atividades } \\
\text { de implantação e apoio de informática }\end{array}$ \\
\hline 1 & $\begin{array}{l}\text { Coordenadora de Planejamento e } \\
\text { Controle }\end{array}$ & Engenheiro Civil & $\begin{array}{l}\text { Treinamento dos membros do projeto e coordenação das atividades } \\
\text { de implantação e apoio técnico às obras }\end{array}$ \\
\hline 1 & Engenheiro de Planejamento e Controle & Engenheiro Civil & \multirow{3}{*}{$\begin{array}{l}\text { Implantação dos dados da obras e apoio aos membros do projeto } \\
\text { após implantação da ferramenta }\end{array}$} \\
\hline 1 & Engenheiro de Planejamento e Controle & Engenheiro Elétrico & \\
\hline 1 & Assistente Técnico & $\begin{array}{l}\text { Tecnólogo em Construção } \\
\text { Civil }\end{array}$ & \\
\hline
\end{tabular}

Quadro 20 - Cargos e Responsabilidades da equipe de implementação - Fase 2 - Empresa A

Cabe ressaltar que, além dos profissionais envolvidos exclusivamente na implementação, relacionados na tabela acima, em cada obra, ou departamento, foi nomeado um responsável pelo sistema. Na empresa, a denominação utilizada para esse profissional era de "ponto focal".

\subsubsection{Critérios estabelecidos com relação à utilização do sistema}

Os critérios estabelecidos pela construtora com relação à utilização do sistema de gestão de contratos foram divididos nos seguintes tópicos: 
- elaboração/organização dos dados a serem implantados no sistema (carga inicial);

- manutenção dos dados da obra no sistema integrado para gestão de contratos de obras;

- controle físico e financeiro.

\section{a. Elaboração/organização dos dados a serem implantados no sistema}

Para elaboração/organização dos dados a serem implantados no sistema, a empresa construtora definiu alguns critérios, abaixo relacionados:

\section{- Definição da EAP - Estrutura Analítica de Projetos}

$\mathrm{Na}$ maioria das vezes, a EAP é definida pelo próprio cliente. Quando o cliente não a tem, a EAP é feita pela obra com o apoio da equipe de planejamento da sede, respeitando as especificidades do projeto.

\section{- Ferramenta utilizada para elaboração do cronograma físico da obra} A empresa utiliza, na maioria das vezes, o MS-Project 2003, porém, em algumas obras, geralmente, na Petrobrás, é utilizado o Primavera (P6), conforme definido em contrato.

- Nível de detalhamento da EAP - Estrutura Analítica de Projetos no cronograma (elaborado no MS-Project ou Primavera)

O nível de detalhamento da EAP, geralmente, é definido pela equipe da obra, juntamente com a sede. Algumas vezes, é definido pela equipe da obra e planejamento da sede, juntamente com o cliente, como no caso das obras da Petrobrás.

- Nível de detalhamento da EAP - Estrutura Analítica de Projetos no EBS - EBusiness Suite

Definida a EAP e seu respectivo detalhamento, determina-se definido o nível de 
detalhamento a ser controlado no EBS. Na empresa, isso é de responsabilidade da área de planejamento e controle da sede, com a aprovação da equipe da obra.

\section{- Elaboração do orçamento de custo e receita}

A elaboração dos orçamentos que vão para o EBS são os mesmos da fase de proposta, portanto, são feitos pela área de orçamento da construtora e são utilizados como baseline.

- Carga dos dados iniciais (baseline) na ferramenta

A carga de dados iniciais, como cronograma, orçamento de custo e orçamento de receita, é de responsabilidade da área de planejamento da sede.

b. Manutenção dos dados da obra no sistema integrado para gestão de contratos de obras

\section{- Atualização e manutenção dos dados do cronograma}

A obra é responsável pela atualização do cronograma no MS-Project e por meio de um integrador do EBS. As informações do cronograma são atualizadas automaticamente no plano de trabalho do EBS.

\section{- Ponderação utilizada para gerar o percentual de avanço físico do projeto}

A empresa definiu como critério a ponderação no $\mathrm{Hh}$, porém, nos casos em que ele não se aplica, por exemplo, obras com pouca incidência de homens-horas e muita incidência de equipamentos, é recomendada a utilização da ponderação pelo custo. Essa ponderação do avanço físico do projeto é configurada no próprio MS-Project.

\section{- Atualização dos orçamentos de custo}

A obra atualiza o orçamento, com aprovação dos gestores, que é carregado no EBS pela área de planejamento e controle da sede. 


\section{- Nível de detalhamento dos orçamentos}

Os orçamentos são elaborados pela respectiva área da sede, detalhando composições de serviços e insumos. Porém a carga do orçamento no EBS é feita de forma macro, por exemplo, ao invés de carregar os insumos, quantidades e custos unitários da etapa de estrutura, é carregada a verba de material, serviço, mão-de-obra e equipamentos.

\section{- Estrutura de organização dos recursos - ERS}

Os recursos são separados por tipo de insumo, por exemplo, material, mão-deobra, serviço, equipamentos, sendo que o cadastramento é realizado por empresa contratada e especializada nesse tipo de tarefa. Além disso, os recursos cadastrados são utilizados no processo de compra, por isso devem ser criteriosamente cadastrados.

\section{- Informações de custos realizados no sistema}

Após o recebimento do material, por exemplo, o do cimento na obra, é feito o cadastramento da nota fiscal no sistema JDE, que será relacionado ao pedido de material anteriormente realizado. Esse cadastramento indica que houve um lançamento de custo na ferramenta que é enviado, via integração, para o EBS, gerando, dessa forma, a informação do custo realizado do projeto, custo esse que é apropriado na mesma etapa (EAP do projeto) em que ele foi solicitado. Portanto, o custo realizado é visualizado no nível das etapas do projeto e pode ser comparado facilmente com o custo planejado.

\section{- Atualização do orçamento de venda}

A obra atualiza o orçamento de venda, depois de o cliente ter aprovado o aditivo. Após a aprovação, ele é carregado no EBS pela área de planejamento e controle da sede.

\section{- Informações de receita realizada no sistema}

As informações da receita recebida por obra são cadastradas manualmente. 


\section{c. Controle físico e financeiro}

- Monitoramento das informações atualizadas no sistema

A equipe de planejamento e controle da sede monitora a atualização dos dados, por exemplo, avanço físico mensal e indicadores de desempenho.

- Controle físico e financeiro é na mesma estrutura (EAP)

$O$ relacionamento entre a estrutura física (EAP) e a financeira (EFP) ou seja, WBS $\times$ FBS, é completamente espelhado, ou seja, as tarefas contidas e acompanhadas fisicamente são as mesmas financeiramente.

\section{- Análise do valor agregado}

A empresa utiliza a análise do valor agregado nos projetos implementados e também baseia-se no cálculo dos seguintes indicadores: IDC- índice de desempenho de custo, IDP - índice de desempenho de prazo e IDAC - índice de desempenho a concluir.

\subsubsection{Dificuldades enfrentadas}

As dificuldades enfrentadas podem ser divididas conforme as fases de implementação.

\section{a. Fase 1 - processos iniciais para implementação do sistema}

Na fase inicial, as dificuldades observadas pela construtora foram as seguintes:

- A empresa contratada para implantar a ferramenta alocou profissionais inexperientes, os quais não possuíam conhecimento da ferramenta;

- O cronograma era muito otimista e previa a implementação em apenas cinco meses; 
- Houve necessidade de rescindir o contrato com a empresa implementadora, devido aos seguintes fatos: falta de domínio da ferramenta e atrasos no cronograma inicial;

- A construtora não possuía domínio dos processos, o que demandava seu mapeamento;

- A construtora não possuía pleno domínio dos conceitos e práticas recomendados pelo PMI e aplicados no MS-Project, demandando tempo maior para estudo dos conceitos.

\section{b. Fase 2 - implementação do sistema nos departamentos e obras}

Os dados da obra nem sempre estavam disponíveis, havendo necessidade de organizá-los com a equipe da obra;

- Dificuldade na utilização do MS-Project, ferramenta que alimenta o cronograma do sistema de gestão;

- Falta de domínio dos conceitos e práticas recomendados pelo PMI e aplicados no MS-Project;

- Falta de tempo, por parte da obra, em participar dos treinamentos;

- Os profissionais da obra não possuíam a cultura de gestão de projetos (PMI).

\subsubsection{Resultados observados após a implementação}

0 contato realizado ${ }^{42}$ com o key-user da ferramenta, permitiu identificar os seguintes resultados com a implementação do sistema:

${ }_{42} 0$ contato com o key-user da ferramenta foi realizado através de entrevista e visitas à empresa construtora. 
- Utilização de sistema para gestão de projetos, orientando as práticas internacionais no assunto;

- Governança corporativa;

- Organização das informações em uma única base de dados (orçamentos de custo, receita, aditivos, cronograma, contrato, etc.);

- Estruturação das informações conforme EAP da obra;

- Organização da documentação, desde a fase inicial da obra;

- Imposição da atualização do cronograma;

- Padronização de procedimentos de planejamento e controle em todas as obras.

\subsection{Estudo de caso 2}

\subsubsection{Caracterização da construtora B}

Em 1973, a empresa é fundada para atuar apenas no território brasileiro. Em 1994, passa a atuar em território estrangeiro, inicialmente, no Uruguai, e, em 2005, intensifica sua atuação no Mercosul, iniciando suas atividades no mercado argentino.

Durante seus mais de 22 anos de atuação, a construtora teve trajetória marcada pela execução de mais de 280 contratos nos setores de cimento, siderurgia, mineração, energia, óleo e gás e, hoje, tem a Petrobrás como seu principal cliente.

Em 2007, a empresa finalizou o ano com o maior lucro líquido da sua história (14,6 milhões de reais) e atualmente possui 17 obras em andamento. 
De acordo com a Revista O Empreiteiro (2010), a empresa encontra-se entre as 25 maiores construtoras do Brasil, com faturamento em torno de 650 milhões de Reais.

\subsubsection{Estratégia de implementação}

A implementação do sistema na empresa ocorreu em três fases bem definidas, sendo que a primeira e a segunda fases estavam definidas no plano inicial e a terceira se deu devido às dificuldades ocorridas nas duas primeiras fases.

\section{a. Fase 1}

$\mathrm{Na}$ fase 1, foram realizados os levantamentos das necessidades, práticas adotadas pela empresa com relação à gestão dos projetos e processos atuais na empresa, atividade que geralmente ocorre preliminarmente à implementação do sistema de gestão de contratos.

$\mathrm{Na}$ sequência, iniciaram-se as configurações e as customizações na ferramenta, lembrando que, no processo de levantamento das necessidades, foram definidas como imprescindíveis nove customizações, ou seja, processos que devem ser criados na ferramenta para atender a necessidade específica da empresa. Essa atividade demanda horas de programadores, exigindo deles um profundo conhecimento do sistema, pois terão a missão de encaixar os novos processos dentro dos já existentes no sistema.

Após as configurações e customizações, foram iniciados os testes, sendo apontados os erros e realizadas as devidas correções.

Embora não tivesse sido finalizada a etapa de testes unitários, já que alguns problemas não foram sanados, nessa etapa, partiu-se para a homologação do sistema, que consiste na apresentação, para os colaboradores envolvidos, dos processos dentro do sistema. 
Cabe ressaltar que não houve um teste integrado das funcionalidades da ferramenta e a empresa optou por partir para a fase seguinte.

\section{b. Fase 2}

A fase 2 ocorreu simultaneamente nas obras. Para isso, houve a paralisação dos processos por 1 semana, antes do Go-live, para que a migração de um sistema para o outro fosse realizada.

Antes do Go-live, ocorreram os treinamentos, que habilitaram os profissionais na utilização da ferramenta.

Com a habilitação na ferramenta o profissional responsável na obra deveria, carregar os dados iniciais do projeto, ou seja, implantar o cronograma, orçamento e baseline.

Treinamento: foram realizados treinamentos gerais, em salas de hotéis e aos finais de semana. No total, foram três semanas dedicadas exclusivamente aos treinamentos da equipe, que foi dividido por turma, de acordo com a função no projeto. Assim, houve treinamentos específicos para profissionais da área administrativa e outros apenas para os coordenadores e gerentes, totalizando 250 profissionais treinados. No quadro 21 , é exibida a grade de treinamento utilizada pela empresa. 


\begin{tabular}{|c|c|c|}
\hline Ferramenta & Assuntos abordados no treinamento & Carga horária (horas) \\
\hline EBS - Módulo de suprimentos & Requisições & 4 \\
\hline EBS - Módulo de suprimentos & Recebimento Integrado & 4 \\
\hline EBS - Módulo de Projetos & Como montar projeto no EBS & 16 \\
\hline EBS - Módulo de Projetos & Como atualizar dados do projeto & 6 \\
\hline EBS - Módulo de Projetos & Relatórios e indicadores & 4 \\
\hline EBS - Geral & $\begin{array}{l}\text { Aprovações no sistema } \\
\text { - planos de trabalho } \\
\text { - planos financeiros } \\
\text { - ordem de compra } \\
\text { - requisições }\end{array}$ & 2 \\
\hline \multicolumn{2}{|c|}{ CARGA HORÁRIA TOTAL } & 36 \\
\hline
\end{tabular}

Quadro 21 - Carga horária dos treinamentos - Empresa B

\subsubsection{Cronograma de implementação}

A implementação do sistema de gestão de contratos iniciou-se em novembro de 2007 e foi finalizada em maio de 2010, totalizando 32 meses, conforme Figura 30.

Nesse período, pode-se separar a implementação nas seguintes fases principais:

FASE 1 - teve duração de nove meses e ocorreu no período de novembro de 2007 até julho de 2008. O prazo foi devidamente respeitado, em relação ao cronograma inicial, não havendo atrasos. 
FASE 2 - não estava prevista em cronograma e a paralisação de uma semana para migração dos processos para a nova ferramenta, estendeu-se por cinco meses, no período de agosto de 2008 até dezembro de 2008.

FASE 3 - em consequência dos problemas ocorridos na Fase 2, foi necessário preparar um plano de ação para os ajustes e implementação de melhorias. Esse plano teve duração de 17 meses e ocorreu no período de janeiro de 2009 até maio de 2010.

EMPRESA B

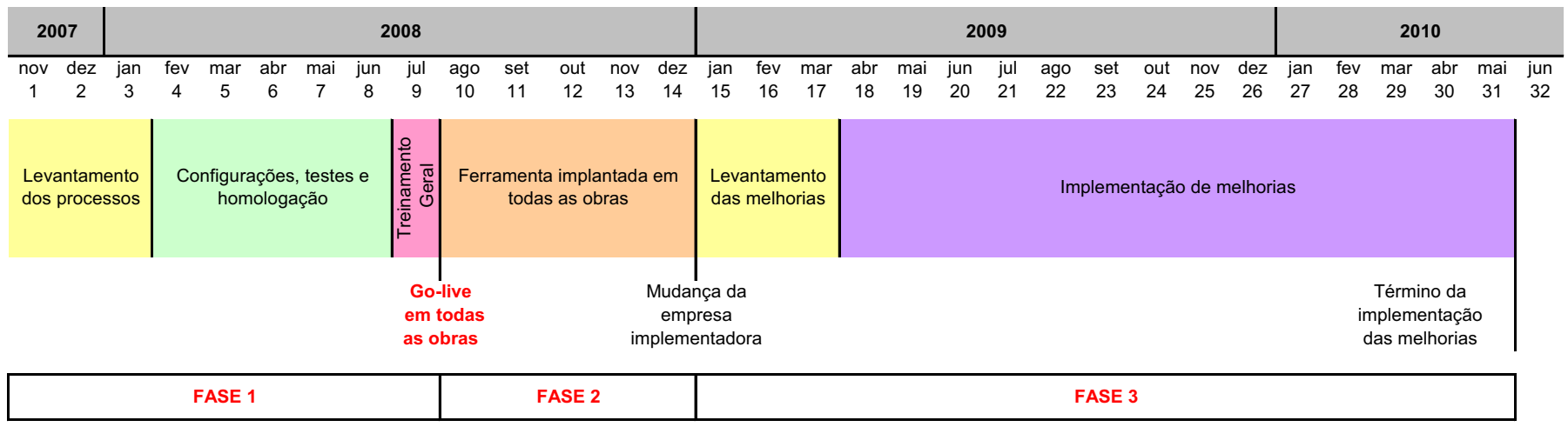

Figura 30 - Cronograma de implementação do sistema - Empresa B

No cronograma, percebe-se, ainda, que a FASE 3 iniciou-se após a mudança da empresa implementadora, ou seja, após cinco meses de grande dificuldade na utilização do sistema implantado. A direção da empresa tomou a decisão de mudar a empresa de implementação, partindo, em seguida para um plano de ação com o objetivo de ajustar os problemas das fases anteriores.

\subsubsection{Funções e responsabilidades dos profissionais envolvidos}

Antes de iniciar a implementação, a empresa preparou a equipe de profissionais envolvidos, devido à complexidade do processo. A empresa custeou treinamentos das práticas PMI e exigiu que todos os funcionários que fossem participar do 
projeto tivessem a certificação PMP - Project Management Professional ${ }^{43}$, o que permitiu um melhor conhecimento da equipe em relação as suas funções no projeto e das práticas de gestão.

Sobre a equipe de implementação, como esta ocorreu em três fases, as funções e as responsabilidades são diferentes para cada uma delas, conforme abaixo descrito:

Funções e Responsabilidades da Equipe de Implementação - Fase 1: a equipe da fase 1 era composta por 20 profissionais, divididos em cinco lideranças, todas com autonomia na tomada de decisão.

Funções e Responsabilidades da Equipe de Implementação - Fase 2: a equipe da fase 2 também era composta por 20 profissionais, divididos em cinco lideranças, todas subordinadas diretamente ao diretor da empresa, conforme Figura 31.

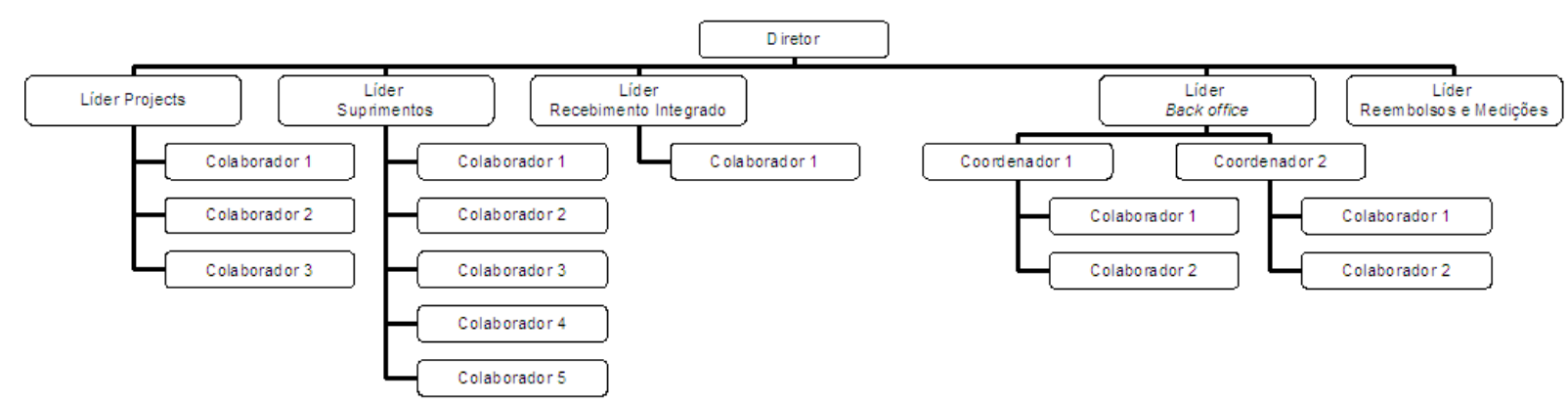

Figura 31 - Organograma da equipe de implementação do sistema - Empresa B

Líder de projects: responsável pela implementação do módulo de gestão de projeto

${ }^{43}$ Certificação dada pelo PMI - Project Management Institute ao profissional habilitado na gestão de projetos. 
Líder de suprimentos: responsável pela implementação do módulo de suprimentos integrado.

Líder de recebimento integrado: responsável pela implementação do módulo de Recebimento (Notas fiscais/contas a pagar)

Líder de back-office: responsável pela integração dos processos administrativos, contábeis e financeiros

Líder de reembolso e medições: responsável pelos processos de implementação dos módulos de reembolso e medições

Das funções contidas no organograma, estavam com dedicação exclusiva dez profissionais. E nas fases de testes, mais seis profissionais estavam envolvidos nas atividades relacionadas à área de suprimentos.

Funções e Responsabilidades da Equipe de Implementação - Fase 3: na fase 3 nomeou-se um responsável (key-user) para cada módulo da ferramenta, totalizando cinco pessoas, conforme estrutura do organograma. Além disso, a equipe da obra passou a se envolver na ativamente implementação.

\subsubsection{Critérios estabelecidos com relação à utilização do sistema}

Como no estudo de caso apresentado anteriormente, pretende-se apresentar os critérios estabelecidos pela empresa, com relação à utilização do sistema de gestão de contratos. Para isso, eles foram divididos nos seguintes tópicos:

- elaboração/organização dos dados a serem implantados no sistema (carga inicial); 
- manutenção dos dados da obra no sistema integrado para gestão de contratos de obras;

- controle físico e financeiro.

\section{a. Elaboração/organização dos dados a serem implantados no Sistema}

Para elaboração/organização dos dados a serem implantados no sistema, a empresa construtora definiu alguns critérios, conforme abaixo relacionados:

\section{- Definição da EAP - Estrutura Analítica de Projetos}

A EAP utilizada na ferramenta é padrão para todos os projetos e foi definida pela área de PMO - Project Management Office ${ }^{44}$ da empresa. A EAP padrão envolve até o nível da top task ${ }^{45}$, sendo as tasks ${ }^{46}$ definidas, conforme planilha do cliente.

\section{- Ferramenta utilizada para elaboração do cronograma físico da obra}

A empresa utiliza o MS-Project 2003.

- Nível de detalhamento da EAP - Estrutura Analítica de Projetos no cronograma (elaborado no MS-Project)

Como a obra possui dois cronogramas (um executivo e outro apenas para atender o EBS), o executivo é mais detalhado, porém ambos baseiam-se no procedimento da empresa, com orientação de que o detalhamento deve ser até o nível do pacote de contratação.

- Nível de detalhamento da EAP - Estrutura Analítica de Projetos no EBS - EBusiness Suite

O nível é definido pela equipe da obra com o PMO, mas existe um

\footnotetext{
${ }^{44}$ PMO - Project Management Office, termo utilizado para definir-se Escritório de Projeto.

${ }^{45}$ Top tasks é o termo utilizado para se referir ao nível da etapa na EAP.

${ }^{46}$ Tasks é o termo utilizado para se referir ao nível da atividade na EAP.
} 
procedimento orientando que o detalhamento deve ser até o nível do pacote de contratação.

- Elaboração do orçamento de custo e receita

A elaboração dos orçamentos que vão para o EBS é a mesma da fase de proposta, portanto, é feita pela área de orçamento da construtora e utilizada como baseline.

- Carga dos dados iniciais (baseline) na ferramenta

A carga de dados iniciais, como cronograma, orçamento de custo e orçamento de receita, é de responsabilidade do engenheiro de planejamento da obra.

b. Manutenção dos dados da obra no sistema integrado para gestão de contratos de obras

\section{- Atualização e manutenção dos dados do cronograma}

A obra é responsável pela atualização do cronograma executivo elaborado no MS-Project. Esse cronograma alimenta o cronograma resumido que, por sua vez, alimentará o EBS por meio do integrador da ferramenta com o MS-Project.

- Ponderação utilizada para gerar o percentual de avanço físico do projeto

A empresa definiu como critério a ponderação pelo custo, porém a utilizada no MS-Project é pela duração, assim o avanço físico do projeto é diferente entre o EBS e o MS-Project.

\section{- Atualização dos orçamentos de custo}

A obra utiliza a interação com o MS-Project para atualizar o orçamento, já que a coluna custo do MS-Project é lida pelo EBS. 
- Nível de detalhamento dos orçamentos

Os orçamentos são elaborados pela respectiva área e são detalhados e valorizados no nível do pacote de contratação, conforme tipo de recurso, ou seja, material, serviço, mão-de-obra e equipamentos.

\section{- Estrutura de organização dos recursos - ERS}

Os recursos são separados por tipo de insumo, por exemplo, material, mão-deobra, serviço, equipamentos, sendo que existem dois cadastramentos. Um deles é realizado pelo PMO da empresa e abastece o orçamento e o outro pela equipe de TI provendo o processo de compras.

\section{- Informações de custos realizados no sistema}

Como o pedido e o recebimento do material na obra são realizados no mesmo sistema, a informação é atualizada automaticamente. Os custos previstos e realizados podem ser comparados no nível do pacote de contratação.

\section{- Atualização do orçamento de venda}

A obra atualiza o orçamento de venda diretamente no EBS, depois de a aprovação ter passado pelo gerente do projeto, diretor e cliente.

\section{- Informações de receita realizada no sistema}

A medição ${ }^{47}$ é feita diretamente no EBS, gerando automaticamente os valores de receita realizada.

\footnotetext{
47 Cabe ressaltar neste ponto, que a empresa não trabalha com contratos do tipo preço unitário, onde são apresentados valores unitários para cada serviço realizado (Lei 8.666, 1993), portanto a medição possui poucos elementos/serviços.
} 


\section{c. Controle Físico e Financeiro}

- Monitoramento das informações atualizadas no sistema

O PMO monitora a atualização do avanço físico, orçamentos, receita e indicadores. E a controladoria, os valores de custos.

- Controle físico e financeiro é na mesma estrutura (EAP)

$O$ relacionamento entre a estrutura física (EAP) e financeira (EFP) ou seja, WBS x FBS, é parcialmente compartilhado, ou seja, alguns itens são iguais e outros não.

\section{- Análise do valor agregado}

A empresa utiliza a análise do valor agregado nos projetos implementados e também baseia-se no cálculo dos seguintes indicadores: IDC- Índice de Desempenho de Custo e IDP - Índice de Desempenho de Prazo.

\subsubsection{Dificuldades enfrentadas}

As dificuldades enfrentadas podem ser divididas conforme as fases de implementação.

\section{a. Fase 1 - implementação do sistema de gestão de contratos}

$\mathrm{Na}$ fase inicial, as dificuldades observadas foram as seguintes:

- A empresa contratada para implantar a ferramenta alocou profissionais inexperientes, os quais não possuíam conhecimento da ferramenta (EBS);

- Houve muitas customizações na ferramenta, o que demandava muitos testes que não foram concluídos adequadamente; 
- Os treinamentos ocorreram no mesmo período dos testes, havendo pouco afinco na sua realização, já que os key-users estavam envolvidos nos treinamentos;

- O cronograma foi cumprido, relevando testes integrados, que são imprescindíveis para a qualidade final do produto;

- A migração dos dados, do sistema antigo para o atual, ocorreu simultaneamente em todas as obras;

- Embora a empresa implementadora não tivesse domínio da ferramenta, as etapas foram passadas;

- O comitê de implementação não possuía liderança, havendo autonomia excessiva dos cinco líderes do projeto;

- Ocorreram problemas com a integração do MS-Project e EBS;

- Toda a responsabilidade na implantação dos dados do projeto foi repassada para a obra.

\section{b. Fase 2 - diagnóstico da implementação ocorrida na Fase 1}

- Ocorreram paralisações em vários processos devido aos problemas com a ferramenta implementada;

- Os processos que envolviam customizações, por não terem sido testados corretamente, não funcionavam como planejados;

- Houve necessidade de rescindir o contrato com a empresa implementadora, devido aos problemas ocorridos;

- A empresa desenvolvedora da ferramenta não possuía cases nacionais havendo necessidade de viagens internacionais para melhor conhecimento da utilização da ferramenta. 
c. Fase 3 - ajustes e melhorias na implementação ocorrida nas fases 1 e 2

- A nova empresa implementadora precisou reiniciar os estudos dos processos para reimplantação de alguns módulos;

- Toda a equipe responsável pela implementação da fase 1 foi mudada pela diretoria da empresa;

- Devido à necessidade de se ajustar vários processos, todos os testes tiveram que ser refeitos.

\subsubsection{Resultados observados após a implementação}

Por meio do contato realizado ${ }^{48}$ com o key-user da ferramenta, foram identificados os seguintes resultados alcançados com a implementação do sistema:

- Centralização do processo de compras, permitindo maior transparência aos gestores;

- Utilização de sistema para gestão de projetos, segundo às práticas internacionais de gestão;

- Acompanhamento do projeto por indicadores;

- Melhor controle de custos e receitas do projeto;

- Melhor controle do cronograma do projeto.

${ }^{48} \mathrm{O}$ contato com o key-user da ferramenta foi realizado através de entrevista e visitas à empresa construtora. 


\subsection{Estudo de caso 3}

\subsubsection{Caracterização da construtora $C$}

Fundada em 1981, a construtora C atua nas áreas de engenharia, empreendimentos imobiliários, residencial, gestão de estaleiro para a construção de plataformas offshore, além de dedicar-se nos investimentos em infra estrutura.

Com uma posição consolidada no mercado, possui um portfólio de mais de 200 projetos, quantificando, até o momento, mais de 5 milhões de metros quadrados construídos.

Os clientes da empresa são líderes de mercado e exigem o mais alto nível de qualidade e cumprimento de prazos e para superar essas expectativas, a empresa está estruturada em três pilares fundamentais: estratégia, organização e pessoas.

De acordo com a Revista Exame (2010), a construtora encontra-se entre as 1.000 maiores empresas do Brasil e entre as 20 maiores construtoras do país, com faturamento em torno de 700 milhões de Reais (O EMPREITEIRO, 2010).

\subsubsection{Estratégia de implementação}

A implementação do sistema na empresa ocorreu simultaneamente em 10 obras e em duas fases bem definidas, conforme descrito a seguir:

\section{a. Fase 1}

$\mathrm{Na}$ fase 1, foram realizados os levantamentos das necessidades e processos atuais na empresa, atividade que geralmente ocorre preliminarmente à implementação 
do sistema de gestão de contratos. Posteriormente, iniciaram-se as configurações e as customizações na ferramenta. Nesse período foram realizados 3 testes integrados, sendo mapeados todos os problemas da ferramenta.

\section{b. Fase 2}

A fase 2 ocorreu simultaneamente em 10 obras. Para isso, um mês antes do Golive os coordenadores de custo das respectivas obras foram envolvidos e participaram diretamente da implementação.

Para isso, um mês antes do Go-live, ocorreram os treinamentos que habilitaram os profissionais na utilização da ferramenta.

Com a habilitação na ferramenta o profissional responsável na obra (Coordenador de custos) foi responsável por carregar os dados iniciais do projeto, ou seja, implantar o cronograma, orçamento e baseline.

Treinamento: foram realizados treinamentos gerais, no escritório da empresa. No total, foram quatro semanas dedicadas exclusivamente aos treinamentos da equipe.

Os treinamentos foram divididos por turma, de acordo com a função no projeto. Por exemplo, houve treinamentos específicos para profissionais da área operacional e outro apenas para os gerentes de projeto, sendo que, no total, foram treinados aproximadamente 100 profissionais. No quadro 22 é exibida a grade de treinamento utilizada pela empresa. 


\begin{tabular}{|l|c|c|}
\hline \multicolumn{1}{|c|}{ Ferramenta } & \multicolumn{1}{|c|}{ Assuntos abordados no treinamento } & $\begin{array}{c}\text { Carga horária } \\
\text { (horas) }\end{array}$ \\
\hline CRM & & 1 \\
\hline Requisição & Requisição / hierarquia de aprovação & 1 \\
\hline Ordem de Compra & Ordens de compra / hierarquia de aprovação & 2 \\
\hline Ordem de compra & Completo para suprimentos & 4 \\
\hline Project & Project Costing / Project management - completo & 32 \\
\hline Reembolso de despesa & & 30 min \\
\hline Recebimento integrado & & 4 \\
\hline & & 44 \\
\hline
\end{tabular}

Quadro 22 - Carga horária dos treinamentos - Empresa C

\subsubsection{Cronograma de implementação}

A implementação do sistema de gestão de contratos teve duração de 12 meses, iniciando-se em outubro de 2008 e finalizando em setembro de 2009, um mês antes do cronograma original, cujo término estava previsto para outubro de 2009 , conforme Figura 32.

Nesse período, pode-se separar a implementação nas seguintes fases principais:

FASE 1 - teve duração de 10 meses e ocorreu no período de outubro de 2008 até julho de 2009. O prazo foi devidamente respeitado, havendo antecipação de 1 mês em relação ao cronograma inicial.

FASE 2 - iniciou-se em agosto de 2008, com o treinamento geral dos departamentos e obras da empresa, sendo seguida do Go-live em todas as obras. 0 período de setembro de 2009 até outubro de 2010 se destaca como a fase de adaptação da empresa ao novo sistema. 
EMPRESA C

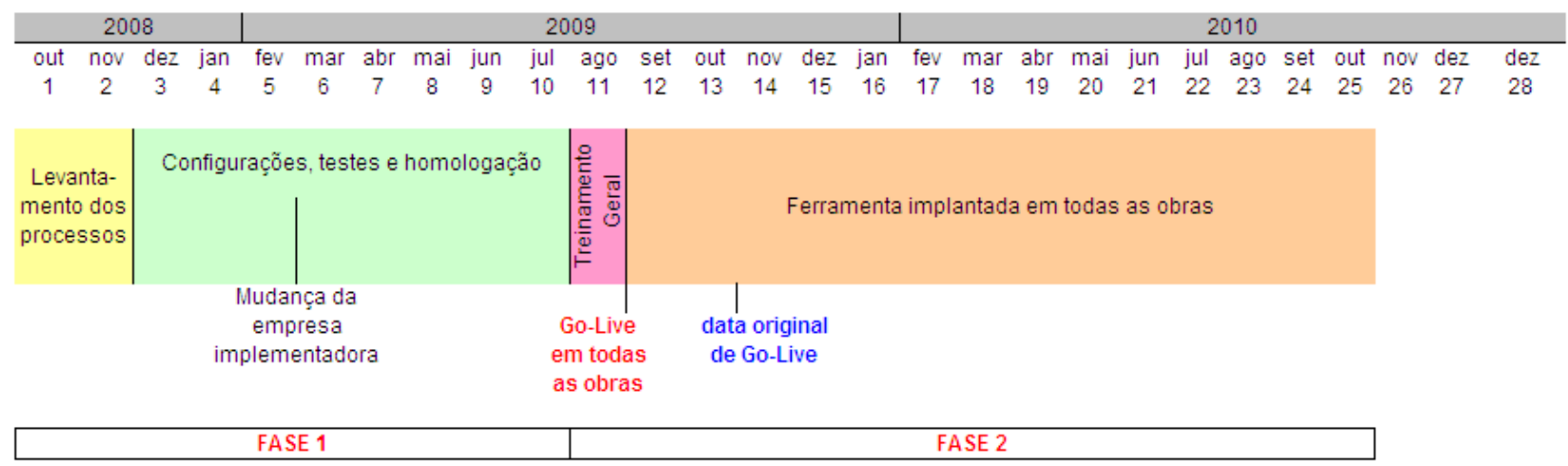

Figura 32 - Cronograma de implementação do sistema - Empresa C

\subsubsection{Funções e responsabilidades dos profissionais envolvidos}

Funções e responsabilidades da equipe de implementação - Fase 1: a equipe da fase 1 era composta por 41 profissionais, divididos em cinco lideranças, porém todas as lideranças eram subordinadas diretamente ao Gerente de Projeto e ao Líder das Integrações, conforme figura 33Figura 31. Dos 38 profissionais envolvidos, 14 eram consultores da empresa de implementação.

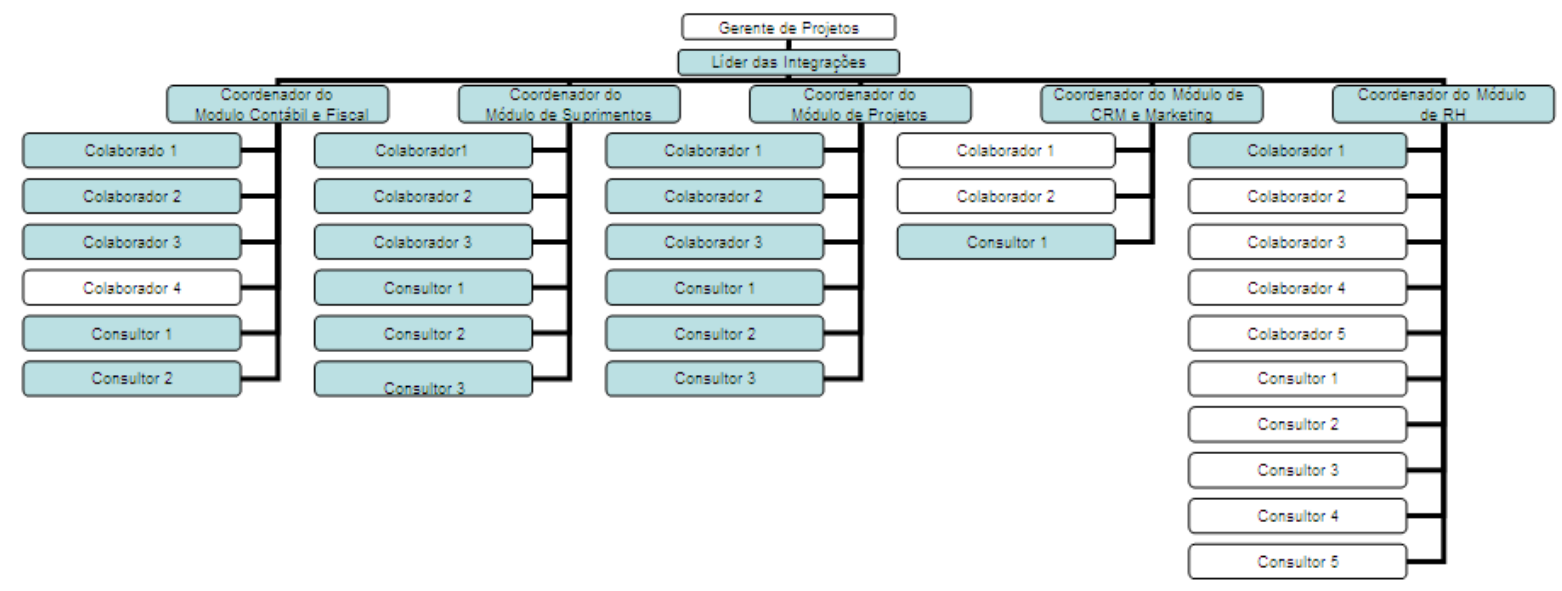


Coordenador do módulo contábil e fiscal: responsável pela integração dos processos administrativos, contábeis e financeiros

Coordenador do módulo de suprimentos: responsável pela implementação do módulo de suprimentos integrado.

Coordenador do módulo de projetos: responsável pela implementação do módulo de gestão de projeto

Coordenador do módulo de CRM e Marketing: responsável pela implementação do módulo de CRM e Marketing.

Coordenador do módulo de RH: responsável pelos processos de implementação dos módulos de folha de pagamento e contratações

Como a implementação foi dividida em duas fases distintas, as funções e as responsabilidades dos profissionais envolvidos também se diferem para as duas fases, conforme descrito a seguir:

Funções e responsabilidades da equipe de implementação - Fase 2: a equipe da fase 2 era composta por cinco profissionais, sendo um de cada módulo específico. Estes foram responsáveis por ministrar os treinamentos para a equipe da obra que foi envolvida um mês antes do Go-live na implementação do sistema.

\subsubsection{Critérios estabelecidos com relação à utilização do sistema}

Os critérios estabelecidos pela empresa com relação à utilização do sistema de gestão de contratos foram divididos nos seguintes tópicos:

- elaboração/organização dos dados a serem implantados no sistema (carga inicial); 
- manutenção dos dados da obra no sistema integrado para gestão de contratos de obras;

- controle físico e financeiro.

\section{a. Elaboração/organização dos dados a serem implantados no sistema}

Para elaboração/organização dos dados a serem implantados no sistema, a empresa construtora definiu alguns critérios, conforme abaixo:

\section{- Definição da EAP - Estrutura Analítica de Projetos}

A EAP utilizada na ferramenta é padrão para todos os projetos e foi definida pela área de Planejamento e Orçamento da construtora, possuindo cerca de 700 linhas.

- Ferramenta utilizada para elaboração do cronograma físico da obra

A empresa utiliza o MS-Project 2003.

- Nível de detalhamento da EAP - Estrutura Analítica de Projetos no cronograma (elaborado no MS-Project) e no EBS - E-Business Suite

O nível de detalhamento segue a EAP definida previamente pela empresa.

\section{- Elaboração do orçamento de custo e receita}

A elaboração dos orçamentos que vão para o EBS são de responsabilidade da área de orçamento da empresa e do engenheiro de custo da obra. O orçamento da fase de proposta geralmente são armazenados como baseline.

\section{- Carga dos dados iniciais (baseline) na ferramenta}

A carga de dados iniciais, como cronograma, orçamento de custo e orçamento de receita, é de responsabilidade da área de controladoria da empresa, com o apoio do engenheiro de planejamento da obra. 
b. Manutenção dos dados da obra no sistema integrado para gestão de contratos de obras

- Atualização e manutenção dos dados do cronograma

O engenheiro de planejamento da obra é responsável pela atualização do cronograma executivo diretamente no EBS.

- Ponderação utilizada para gerar o percentual de avanço físico do projeto A empresa definiu como critério a ponderação no custo.

\section{- Atualização dos orçamentos de custo}

O orçamento de custo é atualizado diretamente no EBS e o responsável pela atualização é o engenheiro de custo da obra.

- Nível de detalhamento dos orçamentos

Os orçamentos são elaborados pela área de orçamento e são detalhados e valorizados no nível da tarefa, conforme EAP definida previamente.

- Estrutura de organização dos recursos - ERS

Os recursos são separados primeiramente por tipo de insumo, por exemplo, material, mão-de-obra, serviço, equipamentos e em seguida por família de recurso, por exemplo: MAT - Armadura (Material: tipo e Armadura: família)

- Informações de custos realizados no sistema

Como o pedido e o recebimento do material na obra são realizados no mesmo sistema, a informação é atualizada automaticamente. Os custos previstos e realizados podem ser comparados no nível da família de recurso.

\section{- Atualização do orçamento de venda}

A obra atualiza o orçamento de venda diretamente no EBS, depois de a aprovação ter passado pelo gerente do projeto, diretor e cliente. 
- Informações de receita realizada no sistema

As informações da receita recebida por obra são cadastradas manualmente.

\section{c. Controle Físico e Financeiro}

\section{- Monitoramento das informações atualizadas no sistema}

A área de Controladoria monitora a atualização do avanço físico, orçamentos, receita e indicadores, além dos valores de custos (previsto $\mathrm{x}$ real).

\section{- Controle físico e financeiro é na mesma estrutura (EAP)}

0 relacionamento entre a estrutura física (EAP) e financeira (EFP) ou seja, WBS $\times$ FBS, é totalmente compartilhado, ou seja, todos os itens constantes no plano de trabalho são idênticos no plano financeiro.

\section{- Análise do valor agregado}

A empresa utiliza a análise do valor agregado nos projetos implementados e também baseia-se no cálculo dos seguintes indicadores: IDC- Índice de Desempenho de Custo e IDP - Índice de Desempenho de Prazo.

\subsubsection{Dificuldades enfrentadas}

As dificuldades enfrentadas referem-se basicamente à utilização do sistema de gestão de contratos, compreendida na fase 2 da implementação e são relacionadas a seguir. Cabe salientar que não foram observadas dificuldades na fase 1.

- A EAP completa demanda muito tempo de atualização. As obras implantadas no final utilizam EAP mais resumida; 
- O sistema não apresenta o nível de detalhamento desejado pelos engenheiros da obra, por exemplo, não há informações sobre produtividade;

- Para uma obra, há mais de um projeto implantado na ferramenta, havendo dificuldade de consolidação dos dados da obra Exemplo: Obra X: projeto 1 (centro de controle 1) e projeto 2 (centro de controle 2).

\subsubsection{Resultados observados após a implementação}

O contato feito ${ }^{49}$ com o key-user permitiu que fossem identificados os seguintes resultados alcançados com a implementação do sistema:

- Governança corporativa;

- Integração de todos os sistemas da empresa;

- Utilização de sistema para gestão de projetos, segundo as práticas internacionais de gestão;

- Há controles paralelos em excel e os dados gerados na ferramenta, por exemplo, custo previsto $x$ real, não são utilizados na plenitude;

- As obras não confiam plenamente nos dados gerados pela ferramenta, pois há inconsistências de cálculo (parte devido à divisão de projetos por centro de controle). Devido a isso, há gestores que formalizaram o pedido para voltar com a ferramenta de gestão antiga.

${ }^{49} \mathrm{O}$ contato com o key-user da ferramenta foi realizado através de entrevista e visitas à empresa construtora. 


\subsection{Análise dos Estudos de Caso}

Após análise dos três estudos de caso, elaborou-se um comparativo entre os aspectos adotados pelas empresas na implementação do sistema, dispondo em quadros os assuntos mais relevantes, nos seguintes tópicos:

- estratégia de implementação (quadro 23);

- cronograma de implementação (quadro 24);

- funções e responsabilidades dos profissionais envolvidos (quadro 25);

- critérios estabelecidos na implementação dos dados (quadro 26).

\begin{tabular}{|c|c|c|}
\hline \multicolumn{3}{|c|}{ ESTRATÉGIA DE IMPLEMENTAÇÃO } \\
\hline Empresa A & Empresa B & Empresa C \\
\hline $\begin{array}{l}\text { Houve treinamento com carga } \\
\text { horária de } 24 \text { horas em gestão } \\
\text { de projeto, para os } \\
\text { profissionais envolvidos na } \\
\text { implementação. }\end{array}$ & $\begin{array}{l}\text { Todos os profissionais } \\
\text { envolvidos na implementação } \\
\text { possuíam a certificação PMP. }\end{array}$ & $\begin{array}{l}\text { Houve treinamento com carga } \\
\text { horária de } 40 \text { horas, com } \\
\text { todos os profissionais } \\
\text { envolvidos na implementação. } \\
\text { O foco do treinamento eram as } \\
\text { funcionalidades do sistema. }\end{array}$ \\
\hline $\begin{array}{l}\text { A estratégia foi conservadora, } \\
\text { pois a empresa preferiu fazer } \\
\text { a implementação gradativa, } \\
\text { obra por obra }\end{array}$ & $\begin{array}{l}\text { A estratégia foi ousada, já que } \\
\text { a empresa optou por } \\
\text { implementar a ferramenta } \\
\text { simultaneamente em todas as } \\
\text { obras }\end{array}$ & $\begin{array}{l}\text { A estratégia foi ousada, já que } \\
\text { a empresa optou por } \\
\text { implementar a ferramenta } \\
\text { simultaneamente em todas as } \\
\text { obras }\end{array}$ \\
\hline $\begin{array}{l}\text { Optou por utilizar o sistema } \\
\text { atual de back-office e apenas } \\
\text { conectá-lo ao sistema de } \\
\text { gestão de contrato, já que } \\
\text { ambos são baseados na } \\
\text { tecnologia suite da Oracle }\end{array}$ & $\begin{array}{l}\text { A empresa implementou o } \\
\text { sistema de gestão de contratos } \\
\text { e também o back-office } \\
\text { simultaneamente }\end{array}$ & $\begin{array}{l}\text { A empresa implementou o } \\
\text { sistema de gestão de contratos } \\
\text { e também o back-office } \\
\text { simultaneamente }\end{array}$ \\
\hline
\end{tabular}




\begin{tabular}{|c|c|c|}
\hline $\begin{array}{l}\text { Os treinamentos foram } \\
\text { realizados por obra } \\
\text { gradativamente }\end{array}$ & $\begin{array}{l}\text { Os treinamentos foram } \\
\text { realizados para a empresa } \\
\text { inteira simultaneamente }\end{array}$ & $\begin{array}{l}\text { Os treinamentos foram } \\
\text { realizados para a empresa } \\
\text { inteira simultaneamente }\end{array}$ \\
\hline
\end{tabular}

Quadro 23 - Comparativo entre as estratégias de implementação das empresas

\begin{tabular}{|c|c|c|}
\hline \multicolumn{3}{|c|}{ CRONOGRAMA DE IMPLEMENTAÇÃO } \\
\hline Empresa A & Empresa B & Empresa C \\
\hline $\begin{array}{l}\text { O cronograma inicial previa a } \\
\text { implementação do módulo de } \\
\text { gerenciamento de projeto e } \\
\text { integração com o sistema de } \\
\text { back-office, em } 5 \text { meses, } \\
\text { postergados para } 9 \text { meses, } \\
\text { devido aos problemas } \\
\text { identificados nos testes e } \\
\text { homologação da ferramenta }\end{array}$ & $\begin{array}{l}\text { O cronograma inicial previa a } \\
\text { implementação em } 7 \text { meses do } \\
\text { ERP completo }\end{array}$ & $\begin{array}{l}\text { O cronograma inicial previa a } \\
\text { implementação em } 12 \text { meses } \\
\text { do ERP completo }\end{array}$ \\
\hline $\begin{array}{l}\text { A empresa preferiu atrasar o } \\
\text { projeto passar por atividades } \\
\text { que poderiam, } \\
\text { posteriormente, dar impacto } \\
\text { negativo na ferramenta }\end{array}$ & $\begin{array}{l}\text { A empresa preferiu cumprir o } \\
\text { cronograma e sanar os } \\
\text { problemas, após o Go-live }\end{array}$ & $\begin{array}{l}\text { A empresa cumpriu o } \\
\text { cronograma, antecipando em } \\
\text { um mês o Go-live }\end{array}$ \\
\hline $\begin{array}{l}\text { Todos os testes planejados } \\
\text { foram realizados e os erros } \\
\text { mapeados }\end{array}$ & $\begin{array}{l}\text { A etapa de teste integrado não } \\
\text { foi realizada }\end{array}$ & $\begin{array}{l}\text { Todos os testes planejados } \\
\text { foram realizados e os erros } \\
\text { mapeados }\end{array}$ \\
\hline $\begin{array}{l}\text { Tempo total da } \\
\text { implementação está estimado } \\
\text { em } 28 \text { meses }\end{array}$ & $\begin{array}{l}\text { Tempo total da } \\
\text { implementação foi de } 32 \\
\text { meses }\end{array}$ & $\begin{array}{l}\text { Tempo total da } \\
\text { implementação foi de } 12 \\
\text { meses }\end{array}$ \\
\hline
\end{tabular}

Quadro 24 - Comparativo entre os cronogramas de implementação das empresas 


\section{FUNÇÕES E RESPONSABILIDADES DOS PROFISSIONAIS ENVOLVIDOS}

\begin{tabular}{|c|c|c|}
\hline Empresa A & Empresa B & Empresa C \\
\hline $\begin{array}{l}\text { Havia um comitê composto por } \\
\text { seis pessoas que definiam as } \\
\text { diretrizes do projeto }\end{array}$ & $\begin{array}{l}\text { Havia } 5 \text { lideranças } \\
\text { subordinadas diretamente ao } \\
\text { diretor da empresa }\end{array}$ & $\begin{array}{l}\text { Havia um Gerente de Projeto } \\
\text { contratado exclusivamente } \\
\text { para a implementação do } \\
\text { sistema e mais } 6 \\
\text { coordenadores }\end{array}$ \\
\hline $\begin{array}{l}\text { A equipe envolvida no projeto } \\
\text { não possuía tomada de decisão } \\
\text { em relação ao projeto }\end{array}$ & $\begin{array}{l}\text { Cada líder possuía tomada de } \\
\text { decisão em relação à sua área } \\
\text { especifica, havendo excesso } \\
\text { de autonomia }\end{array}$ & $\begin{array}{l}\text { O gerente de projeto } \\
\text { juntamente com o Líder das } \\
\text { integrações possuía autonomia } \\
\text { na tomada de decisões }\end{array}$ \\
\hline $\begin{array}{l}14 \text { profissionais tiveram } \\
\text { dedicação exclusiva na } \\
\text { implementação }\end{array}$ & $\begin{array}{l}10 \text { profissionais tiveram } \\
\text { dedicação exclusiva na } \\
\text { implementação }\end{array}$ & $\begin{array}{l}16 \text { profissionais com dedicação } \\
\text { exclusiva }\end{array}$ \\
\hline
\end{tabular}

Quadro 25 - Comparativo entre as funções e responsabilidades dos profissionais envolvidos

\begin{tabular}{|l|l|l|}
\hline \multicolumn{2}{|c|}{ CRITÉRIOS ESTABELECIDOS NA IMPLEMENTAÇÃo DOS DADOS } \\
\hline \multicolumn{1}{|c|}{ Empresa A } & \multicolumn{1}{c|}{ Empresa B } \\
$\begin{array}{l}\text { Toda a carga de dados é } \\
\text { realizada centralmente, ou } \\
\text { seja, pela equipe da sede }\end{array}$ & $\begin{array}{l}\text { A carga de dados é realizada } \\
\text { pelo engenheiro de } \\
\text { planejamento da obra }\end{array}$ & $\begin{array}{l}\text { A carga de dados é realizada } \\
\text { pelo engenheiro de } \\
\text { planejamento da obra }\end{array}$ \\
\hline $\begin{array}{l}\text { Atualização do cronograma } \\
\text { pela equipe de planejamento } \\
\text { da obra, utilizando o MS- } \\
\text { Project }\end{array}$ & $\begin{array}{l}\text { Atualização do cronograma } \\
\text { pela equipe de planejamento } \\
\text { da obra, utilizando o MS- } \\
\text { Project }\end{array}$ & $\begin{array}{l}\text { Atualização do cronograma } \\
\text { pela equipe de planejamento } \\
\text { da obra diretamente no EBS }\end{array}$ \\
\hline $\begin{array}{l}\text { EAP conforme definido com o } \\
\text { cliente }\end{array}$ & $\begin{array}{l}\text { EAP padronizada pela empresa } \\
\text { EAP padronizada pela empresa }\end{array}$ \\
\hline
\end{tabular}




\begin{tabular}{|c|c|c|}
\hline $\begin{array}{l}\text { Orçamento de custo e venda } \\
\text { no nível da etapa }\end{array}$ & $\begin{array}{l}\text { Orçamento de custo e venda } \\
\text { no nível do pacote de } \\
\text { contratação }\end{array}$ & $\begin{array}{l}\text { Orçamento de custo e venda } \\
\text { no nível da Família de recurso } \\
\text { (Exemplo: MAT-ARMADURA) }\end{array}$ \\
\hline $\begin{array}{l}\text { Itens de compras e orçamentos } \\
\text { são padronizados }\end{array}$ & $\begin{array}{l}\text { Itens de compras e orçamento } \\
\text { estão contidos em cadastros } \\
\text { diferentes }\end{array}$ & $\begin{array}{l}\text { Itens de compras e orçamentos } \\
\text { são padronizados }\end{array}$ \\
\hline $\begin{array}{l}\text { Avanço Físico da obra } \\
\text { ponderado no custo ou Hh }\end{array}$ & $\begin{array}{l}\text { Avanço Físico da obra } \\
\text { ponderado na duração }\end{array}$ & $\begin{array}{l}\text { Avanço Físico da obra } \\
\text { ponderado na duração }\end{array}$ \\
\hline
\end{tabular}

Quadro 26 - Comparativo entre os critérios estabelecidos na implementação dos dados

Verifica-se, com essa análise comparativa dos estudos de casos, que alguns pontos devem ser definidos antes da implementação e que estão mais relacionados aos processos e práticas da empresa do que à ferramenta propriamente dita.

Percebe-se também que todos os elementos observados são estratégicos para o sucesso na implementação, portanto, devem ser devidamente estudados e acompanhados pelos responsáveis pela implementação.

\subsubsection{Principais riscos na implementação do sistema}

Com os três estudos de casos, foram observados os principais riscos da implementação da ferramenta na gestão de contratos e suas respectivas ações mitigadoras, ou seja, ações que poderão atenuar ou até eliminar o risco em futuras implementações, conforme quadro 27 : 


\begin{tabular}{|c|c|}
\hline RISCOS & AÇÔES MITIGADORAS \\
\hline $\begin{array}{l}\text { Falta de conhecimento da ferramenta de } \\
\text { gestão por parte da empresa } \\
\text { implementadora; }\end{array}$ & $\begin{array}{l}\text { - analisar detalhadamente o conhecimento } \\
\text { da empresa implementadora, antes da } \\
\text { contratação } \\
\text { - dar preferência por consultores da própria } \\
\text { empresa desenvolvedora } \\
\text { - fazer benchmarking } \\
\text { que implantaram a ferramenta }\end{array}$ \\
\hline $\begin{array}{l}\text { Falta de domínio das práticas internacionais } \\
\text { de gestão; }\end{array}$ & $\begin{array}{l}\text { - promover treinamentos sobre gestão de } \\
\text { projetos } \\
\text { - certificar os profissionais envolvidos (PMP) }\end{array}$ \\
\hline Falta de domínio dos processos internos; & $\begin{array}{l}\text { - envolver/desenvolver uma área de } \\
\text { processos antes de iniciar a implementação }\end{array}$ \\
\hline Necessidade de customizações; & $\begin{array}{l}\text { - entender o processo atual e proposto } \\
\text { detalhadamente } \\
\text { - contrapor os processos atuais aos propostos } \\
\text { pela ferramenta e traçar as vantagens e } \\
\text { desvantagens de mudança de processo } \\
\text { - envolver os profissionais que têm } \\
\text { dificuldade em aceitar mudanças, antes da } \\
\text { implementação das mudanças } \\
\text { - customizar apenas quando as desvantagens } \\
\text { realmente se sobrepuserem às vantagens }\end{array}$ \\
\hline $\begin{array}{l}\text { Barreiras enfrentadas na fase de } \\
\text { implementação, em função do perfil dos } \\
\text { gestores; }\end{array}$ & $\begin{array}{l}\text { - envolver os gestores desde o início da } \\
\text { implementação } \\
\text { - dar atenção especial aos gestores que têm } \\
\text { dificuldade na gestão de mudanças } \\
\text { - ouvir as argumentações é imprescindível, } \\
\text { pois o gestor é o líder e pode conduzir toda a } \\
\text { sua equipe de forma que ela fique contra a } \\
\text { implementação }\end{array}$ \\
\hline
\end{tabular}

${ }^{50}$ Benchmarking: prática de gestão que vem sendo utilizada eficazmente e tem por característica principal a comparação entre as empresas, por exemplo: de práticas, processos, serviços, produtos e outros. (MCCABE, 2001) 
continuação

Dificuldades encontradas na mudança dos processos habituais;

- envolver os profissionais desde o início da implementação

- deixar os profissionais envolvidos na mudança confortáveis em fazer críticas e sugestões

- fazer um levantamento do motivo pelo qual a mudança do processo está criando dificuldades

- salientar que os ajustes poderão ser realizados, caso identificados problemas

- fazer ajustes, caso necessário, envolvendo o profissional que levantou o problema

Controles paralelos devido à desconfiança

- fazer um acompanhamento posterior à com as informações geradas pela implementação, para verificar a utilização ferramenta da ferramenta

- fazer comparativos com os profissionais envolvidos entre o cenário passado e o atual

- comparar os resultados observados pelos profissionais, com os da ferramenta, para que ele tenha confiança nos dados gerados

Quadro 27 - Riscos e ações mitigadoras na implementação da ferramenta (proposição da autora)

\subsection{Limitações da ferramenta na gestão de contratos de obras}

Por meio dos estudos de casos foi possível identificar as principais limitações da ferramenta diante das práticas de mercado e dos processos das empresas, conforme relacionado a seguir:

- Atualização do orçamento: as três empresas estudadas atualizam o orçamento manualmente no EBS, após sua geração em ferramenta específica de orçamento, ou mesmo no excel. Portanto, verifica-se que a ferramenta não possui forma adequada para atualização do orçamento 
havendo retrabalho, já que não se integra com excel ou software de orçamento específico.

- Atualização do cronograma: duas das empresas estudadas possuem dificuldade na atualização do cronograma físico da obra, havendo retrabalho na atualização das informações de avanço físico da tarefa. Uma das empresas, entretanto, utiliza integração direta do MS-Project com o EBS, fazendo a atualização uma única vez. Percebe-se que há uma limitação da ferramenta ou da implementação já que duas das empresas não a utilizam.

- Atualização da receita realizada: duas das empresas estudadas fazem o cadastramento da receita realizada por carga manual, podendo haver erros que geram retrabalho, já que a informação de faturamento é dada no mesmo sistema no módulo de faturamento

- Restrição de versão do MS-Project: nas três empresas estudadas verifica-se que a versão do MS-Project utilizada é a 2003, isso porque 0 sistema EBS conecta-se apenas com esta versão, limitando o up-grade ${ }^{51}$ de versão e consequente melhoria da ferramenta de planejamento e controle (MS-Project).

Porém, as limitações observadas são elementares frente aos benefícios proporcionados pela implementação da ferramenta, conforme diagnóstico realizado com os key-users consultados das empresas construtoras.

\subsection{Considerações acerca dos Estudos de casos}

Com base nos estudos de caso, pode-se verificar que todas as empresas tiveram problemas na implementação. Duas delas os identificaram no momento da

\footnotetext{
${ }^{51}$ Up-grade: termo utilizado em TI, que refere-se há uma atualização para versão mais recente do software.
} 
implementação e a outra sofre, atualmente, com as consequências de uma implementação inadequada.

As empresas A e B tiveram atrasos no cronograma e precisaram substituir a empresa implementadora no meio do processo. A empresa $C$, por outro lado, conseguiu cumprir o cronograma, mas enfrenta problemas atualmente com a aderência da ferramenta nos processos da construtora, havendo inclusive a solicitação formal de substituição da ferramenta.

Além disso, os estudos possibilitaram uma análise dos tipos de implementação de sistema de gestão, apontando as vantagens e desvantagens de algumas práticas, podendo servir de diretriz para futuras implementações.

Dentre os pontos observados, cabe destacar alguns que têm impacto considerável na implementação. Com base neles foram verificadas as vantagens e desvantagens de algumas decisões, conforme descrito no quadro 28 a seguir:

\begin{tabular}{|c|l|c|c|}
\cline { 2 - 4 } \multicolumn{2}{c|}{} & Vantagens & Desvantagens \\
\hline \multirow{2}{*}{$\begin{array}{c}\text { ESTRATÉGIA DE } \\
\text { IMPLEMENTAÇÃO }\end{array}$} & Gradativa & Domínio do processo & Lentidão na implementação \\
\cline { 2 - 4 } & Simultânea & Rapidez na implementação & $\begin{array}{c}\text { Falta de domínio no } \\
\text { processo }\end{array}$ \\
\hline $\begin{array}{c}\text { TOMADA DE } \\
\text { DECISÃO }\end{array}$ & Centralizada & Maior assertividade & $\begin{array}{c}\text { Demanda maior tempo em } \\
\text { discussões e argumentações }\end{array}$ \\
\cline { 2 - 5 } & Descentralizada & Agilidade na implementação & $\begin{array}{c}\text { Autonomia excessiva, } \\
\text { gerando retrabalhos nas } \\
\text { interfaces de processos }\end{array}$ \\
\hline \multirow{2}{*}{\begin{tabular}{c} 
TREINAMENTOS \\
\cline { 2 - 4 }
\end{tabular}} & Focado & $\begin{array}{c}\text { Domínio na utilização da } \\
\text { ferramenta }\end{array}$ & $\begin{array}{c}\text { Falta de domínio das } \\
\text { peculiaridades de cada obra }\end{array}$ \\
\cline { 2 - 4 } & Geral & $\begin{array}{c}\text { Conhecimento das } \\
\text { peculiaridades da obra }\end{array}$ & $\begin{array}{c}\text { Falta de domínio na } \\
\text { utilização da ferramenta }\end{array}$ \\
\hline
\end{tabular}

Quadro 28 - Vantagens e desvantagens de algumas práticas de implementação 
Verifica-se, com isso, que na implementação há basicamente dois pontos que devem ser observados. Um deles é com relação à estratégia geral: a ousadia da empresa construtora, fazendo implementação simultânea, treinamentos gerais e descentralizado as informações, poder gerar insucesso na implementação, já que a mudança de processos e práticas envolve pessoas. E este é o segundo ponto, a maioria das pessoas tem dificuldade com mudanças, há inclusive especialistas em mudanças que ressaltam que as pessoas são a base do iceberg, e geralmente ficam imersas.

Conclui-se, assim, que implementações gradativas tendem a ter maior sucesso, por mudarem a cultura de forma lenta e gradativa, causando menor impacto. Porém, entende-se que como o cenário atual exige mudanças rápidas, a resposta está, cada vez mais, em trabalhar com a gestão das pessoas. Qualificação do pessoal, treinamentos e preparação para as mudanças devem ser constantes na empresa. 
"Ninguém pode começar de novo mas, qualquer um pode fazer um novo fim."

Chico Xavier

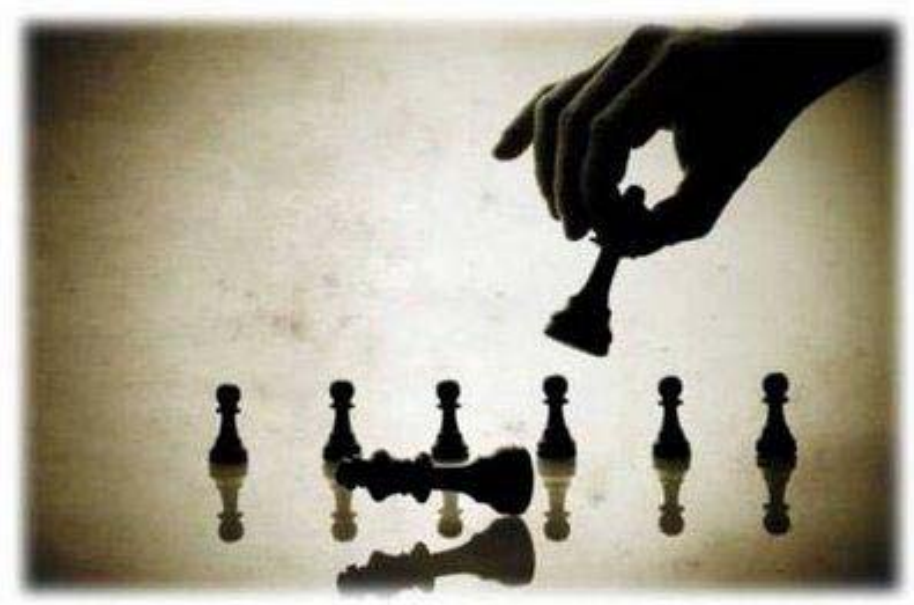




\section{Considerações finais}

Neste capítulo, são apresentados os comentários finais acerca da pesquisa, sendo observados primeiramente o cumprimento dos objetivos iniciais propostos e as dificuldades e limitações do trabalho.

Também deverão ser identificados os resultados obtidos com o trabalho, como as vantagens e desvantagens acerca de algumas práticas observadas nos estudos de caso, os benefícios observados na implementação da ferramenta e a proposição de diretrizes para as futuras implementações.

E, por fim, são relacionadas as perspectivas de continuidade do tema para futuros trabalhos.

\subsection{Cumprimento dos objetivos}

O objetivo principal deste trabalho era contribuir para o conhecimento que envolve o processo de implementação de sistemas integrados para gestão de contratos em empresas de construção civil. Este objetivo foi cumprido, pois foram apresentados desde o conhecimento das práticas de gestão, embutidas na ferramenta até o processo de implementação da ferramenta nos diversos níveis de gestão, permitindo um conhecimento abrangente quanto ao processo de implementação.

Com relação aos objetivos específicos, estes são relacionados no quadro 29, com a respectiva explanação sobre o seu cumprimento. 


\begin{tabular}{|c|c|}
\hline Objetivos específicos & Considerações relativas ao cumprimento do objetivo \\
\hline $\begin{array}{l}\text { Apresentar os níveis de gestão do } \\
\text { contrato e os principais macroprocessos } \\
\text { típicos das empresas construtoras }\end{array}$ & $\begin{array}{l}\text { Foram apresentados os níveis de gestão do contrato e } \\
\text { principais macroprocessos, inclusive, apontando a } \\
\text { influência dos níveis gerenciais na implementação de } \\
\text { ferramentas de gestão }\end{array}$ \\
\hline $\begin{array}{l}\text { Definir e diagnosticar as práticas de } \\
\text { gestão de contratos de obras em } \\
\text { empresas de construção civil }\end{array}$ & $\begin{array}{l}\text { Este objetivo foi alcançado plenamente, já que as } \\
\text { práticas de gestão foram definidas e diagnosticadas } \\
\text { tanto no que diz respeito ao planejamento físico e } \\
\text { financeiro do projeto, quanto com relação ao controle } \\
\text { físico e financeiro das obras }\end{array}$ \\
\hline $\begin{array}{l}\text { Apresentar os processos de } \\
\text { implementação do sistema, discutindo os } \\
\text { motivos da implementação, } \\
\text { aplicabilidade da ferramenta frente às } \\
\text { necessidades da empresa e a aplicação } \\
\text { das práticas de gestão na ferramenta } \\
\text { analisada }\end{array}$ & $\begin{array}{l}\text { Este objetivo foi alcançado parcialmente, tendo em vista } \\
\text { que foram identificados os motivos para implementação } \\
\text { de ferramenta de gestão, porém a aplicabilidade da } \\
\text { ferramenta frente às necessidades da empresa foi } \\
\text { tratada apenas no tocante ao conhecimento dos } \\
\text { processos, não havendo um detalhamento mais } \\
\text { específico com relação às necessidades da construtora. } \\
\text { Já com relação à aplicação das práticas de gestão na } \\
\text { ferramenta analisada, foram apresentados vários } \\
\text { exemplos, inclusive com telas da ferramenta e os } \\
\text { conceitos de planejamento e gestão destacados }\end{array}$ \\
\hline $\begin{array}{l}\text { Discutir os impactos causados com a } \\
\text { implementação do sistema, baseando-se } \\
\text { nos estudos de caso }\end{array}$ & $\begin{array}{l}\text { Este objetivo foi cumprido parcialmente, pois os } \\
\text { impactos foram verificados apenas do ponto de vista do } \\
\text { key-user. Para conclusão final, verificou-se que } \\
\text { poderiam ter sido realizadas entrevistas com } \\
\text { profissionais dos vários níveis de gestão, por exemplo, } \\
\text { engenheiros de obra }\end{array}$ \\
\hline $\begin{array}{l}\text { Identificar as principais limitações da } \\
\text { ferramenta analisada na gestão de } \\
\text { contratos de obras e }\end{array}$ & $\begin{array}{l}\text { Como no anterior, este objetivo foi cumprido } \\
\text { parcialmente, pois as limitações foram verificadas } \\
\text { apenas do ponto de vista do key-user e poderiam ter sido } \\
\text { mais exploradas }\end{array}$ \\
\hline $\begin{array}{l}\text { Propor diretrizes para contribuir em } \\
\text { futuros processos de implementação da } \\
\text { ferramenta }\end{array}$ & $\begin{array}{l}\text { Não apenas a proposição de diretriz foi apresentada, } \\
\text { podendo ser utilizada em futuras implementações, como } \\
\text { o trabalho no geral, já que detalha práticas de gestão } \\
\text { que estão embutidas nos sistemas de gestão }\end{array}$ \\
\hline
\end{tabular}

Quadro 29 - Cumprimento dos objetivos específicos do trabalho 


\subsection{Dificuldades e limitações do trabalho}

Para entender melhor o processo de implementação de sistema de gestão integrado, seria necessário um contato maior com as diversas áreas envolvidas, o que permitiria apontar dificuldades intrínsecas aos processos.

Outro fator que pode ser relevante na análise é o levantamento das informações, que ocorreu após o término da implementação em duas das empresas construtoras (B e C). Dessa forma, outros fatores poderiam ter relevância no processo de implementação, porém não foram observados.

Assuntos como impactos causados com a implementação e principais limitações da ferramenta poderiam ter sido mais explorados, se tivessem sido realizadas entrevistas com outros profissionais envolvidos e não apenas o key-user.

\subsection{Benefícios observados com o sistema de gestão de contratos}

O sistema de gestão de contratos, é importante na gestão de obras de construção civil, podendo garantir a utilização de práticas alinhadas às recomendações internacionais.

Não há dúvidas de que sistemas integrados possibilitam benefícios representativos, conforme observado nos estudos de casos e relacionados no quadro 30, a seguir: 


\section{BENEFÍCIOS}

Governança Corporativa

Padronização dos processos

Sistematização das informações, permitindo organização dos dados gerados

Acompanhamento dos projetos segundo às práticas internacionais de gestão (PMI)

Melhor controle físico e financeiro da obra

Quadro 30 - Benefícios decorrentes da implementação da ferramenta

\subsection{Diretrizes para futuras implementações da ferramenta}

Finalmente, os estudos de implementação de sistema de gestão realizados nas três construtoras permitiram a identificação de uma proposta para futuras implementações, conforme itens relacionados abaixo:

- desenvolvimento de Plano de Ação envolvendo o nível estratégico da empresa;

- criação de comitê, com o apoio do nível estratégico da empresa, para planejamento e gestão do processo de implementação;

- envolvimento e/ou desenvolvimento de área específica para mapeamento dos processos e práticas da empresa;

- mapeamento de todos os processos que serão impactados pela ferramenta, envolvendo os profissionais das referidas áreas; 
- mapeamento das práticas de planejamento e controle;

- análise das ferramentas disponíveis no mercado;

- análise das funcionalidades da ferramenta em relação aos processos e práticas mapeadas;

- escolha da ferramenta a ser implementada, baseada na análise das funcionalidades e nos processos e práticas da construtora;

- benchmarking com outras empresas que utilizam a ferramenta, verificando as estratégias utilizadas na implementação, cronograma, customizações realizadas, práticas utilizadas, etc.;

- análise da empresas implementadoras disponíveis no mercado;

- análise do conhecimento da empresa implementadora, buscando empresas certificadas e com conhecimento em implementações similares;

- qualificação dos profissionais da empresa, não apenas dos envolvidos no processo de implementação, mas de todos os que terão alteração de atividade;

- certificação dos gestores em institutos de renome, para conhecimento das práticas internacionais de gestão, como por exemplo PMI.

Com essa proposta pretende-se, além de minimizar os impactos causados com a mudança de processos, proporcionar diretrizes mais seguras para a implementação, permitindo o cumprimento do cronograma de implementação e aderência do sistema às práticas de gestão da empresa. 


\subsection{Perspectivas de continuidade do estudo do tema ou aspectos correlatos}

0 presente trabalho permitiu identificar temas, cujo desenvolvimento de pesquisas poderia significar avanço do conhecimento na área de gestão de projetos, especificamente na implementação de sistema integrado para gestão de contratos, conforme relacionado a seguir:

- mapeamento dos processos nas empresas de construção civil, possibilitando a apresentação de sugestões que o otimizem e visando a implementação de sistema integrado para gestão de contratos;

- apresentação de metodologia para escolha de sistema integrado para gestão de contratos, analisando a interface, funcionalidades e conceitos embutidos, frente aos processos das empresas construtoras;

- mapeamento dos fatores de risco na mudança de processos de gestão de contratos em empresas de construção civil;

- identificação do papel dos envolvidos no processo de implementação de sistema de gestão e suas responsabilidades;

- aplicabilidade das práticas de gestão de contratos nos diversos níveis de gestão das empresas de construção civil. 
AHUJA, Hira N., DOZZI, S. P., ABOURIZK, S. M. Project Management Techniques in Planning and Controlling Construction Projects. $2^{\text {th }}$ edition, New York: John Wiley \& Sons, 1994.

AKKARI, Abla, BULHÕES, lamara Rossi Bulhões, FORMOSO, Carlos Torres; SOUSA, Max Gil Leite de. Informatização do Planejamento e Controle de Produção. In: SIBRAGEC - Simpósio Brasileiro de Gestão e Economia da Construção, São Carlos, 2003, p.1-8.

AKKARI, Abla. Interligação entre o planejamento de longo, médio e curto prazo com o uso do pacote computacional MS-Project. Porto Alegre, 2003. Dissertação (Mestrado) - Universidade Federal do Rio Grande do Sul.

ALMEIDA, Jorge. Técnicas de Planejamento e Controle aplicadas à Petrobras. Apostila do curso de Supervisor de Planejamento. Rio de Janeiro: PETROBRAS - Petróleo Brasileiro, 2006.

AMORIM, Sergio Leusin de. Gestão. [Entrevista a Kelly Carvalho]. Revista Construção Mercado, n. 54, p. 12- 14, janeiro, 2006.

ANTILL, James M. WOODHEAD, Ronald $W$. Critical path methods in construction practice. $4^{\text {th }}$ edition. New York: John Wiley \& Sons, 1990.

ASSOLARI, Lilian Moreira de Alvarenga. Influência dos sistemas empresariais integrados (ERPs) nos aspectos organizacionais da área de contabilidade : estudo de casos em empresas do Paraná. São Paulo, Setembro 2005. Dissertação (Mestrado) - Faculdade de Economia, Administração e Contabilidade (FEA), Universidade de São Paulo.

ASSUMPÇÃO, José Francisco Pontes. Gerenciamento de Empreendimentos na Construção Civil: Modelo para Planejamento Estratégico da Produção de Edifícios. São Paulo, 1996. Tese (Doutoramento) - Escola Politécnica da Universidade de São Paulo.

${ }^{52}$ De acordo com a ABNT - Associação Brasileira de Normas Técnicas. NBR 6023 (2002). 
ASSUMPÇÃO, José Francisco Pontes; ROCHA Lima Jr., João da. Gerenciamento de Empreendimentos na Construção Civil: Modelo para Planejamento Estratégico da Produção de Edifícios. São Paulo, EPUSP, 1996 (Boletim Técnico. Escola Politécnica da USP. Departamento de Engenharia de Construção Civil, BT/PCC-173/96, 31p.)

ASSUMPÇÃO, José Francisco Pontes. Processos de Gerenciamento de Empreendimentos Aplicados ao Setor de Construção Civil. Salvador, 2007. Notas de aula - Disciplina GEE-017 FDTE /PECE / Escola Politécnica da Universidade de São Paulo.

ATTUCH, Leonardo. A era dos Megaprojetos - Perspectiva 2009 da Revista “Isto É Dinheiro”. Edição 587. São Paulo: Editora Três, 2008.

BALTAZAR, Ana Paula, RYDLEWSKI, Carlos; Um lugar nas nuvens. Revista Veja Especial Tecnologia, São Paulo, p. 22 - 26, Setembro, 2008.

BATEMAN, Thomas S. e SNELL, Scott A. Administração: Construindo Vantagem Competitiva. $1^{\text {a }}$ Edição. São Paulo: Editora Atlas, 1998.

BENAC, Marcos Azevedo. MENDES, Francisco Coelho; SANTOS, Ruthberg dos. A implantação de sistemas integrados de gestão: estudo de caso na Embratel. In: I Seminário de Gestão de Negócios da FAE- Centro Universitário Franciscano, Outubro de 2004, Curitiba, PR.

BERNARDES, Maurício Moreira e Silva. Planejamento e Controle da Produção para Empresas de Construção Civil. $1^{a}$ Edição. Rio de Janeiro: LTC - Livros Técnicos e Científicos, 2003, 190 p.

BERNARDES, Maurício Moreira e Silva. Microsoft Project 2010: Gestão e Desenvolvimento de Projetos. $1^{a}$ Edição. São Paulo: Editora Érica, 2010, $190 \mathrm{p}$.

BOYADJIAN, João Paulo Paes de Barros. A importância da abordagem de gestão de projetos visando a implementação de estratégias organizacionais. São Paulo, Dezembro 2008. Dissertação (Mestrado) - Escola Politécnica, Universidade de São Paulo. 
CARDOSO, Francisco Ferreira e VIVANCOS, Adriano Gameiro. Estruturas Organizacionais e estratégias competitivas de empresas construtoras. In: SIBRAGEC - Simpósio Brasileiro de Gestão e Economia da Construção, Recife, 1999, p.1-10.

CARDOSO, Roberto Sales. Orçamento de obras em foco. Um novo olhar sobre a engenharia de custos. $1^{\text {a }}$ Edição. São Paulo: Editora Pini, 2009.

CAVALCANTE, Paulo Roberto Nobrega; NIYAMA, Jorge Katsumi; REZENDE, Isabelle Carlos Campos. Normas contábeis brasileiras, norte-americanas e internacionais aplicáveis ao setor de construção civil: uma análise comparativa numa empresa do estado da Paraíba. In: IV Congresso ANPCONT - Associação Nacional dos Programas de Pós-Graduação em Ciências Contábeis, Natal, junho 2010. Disponível em: <http://www.anpcont.com.br/site/materia.php?id=47>. Acesso em: 15 maio 2011.

CBIC - Câmara Brasileira da Indústria da Construção. Critério para classificação das construtoras conforme o porte. Belo Horizonte, 2003.

CHAPAVAL, Lea; ALVES, Francisco Selmo Fernandes. Rastreabilidade na Produção: Diferencial para um Agronegócio Sustentável. Janeiro de 2008. Disponível em Portal do Leite no Nordeste <http://anco.cnpc.embrapa.br/artigos.php?sequencia=8>. Acesso em: 10 abril 2010.

CHOMA, André Augusto. Como gerenciar contratos com empreiteiros. $2^{\mathrm{a}}$ edição. São Paulo: Editora Pini, 2008.

COELHO, Julio Moreira. Tecnologia da Informação - Programa da Rossi identifica problemas do sistema SAP. [Entrevista a Bruno Loturco]. Revista Construção Mercado, n. 99, p. 5, outubro, 2009.

ERNST \& YOUNG. Brasil Sustentável - Impactos Socioeconômicos da Copa do Mundo de 2014. Rio de Janeiro: Ernst \& Young, 2010.

FARIA, Carlos Alberto de. A Gestão do Conhecimento e a padronização. Julho de 2008. Disponível em:

<http://www.portaldomarketing.com.br/Artigos1/Gestao_do_conhecimento_e_a_p adronizacao.htm>. Acesso em: 19 abril 2010. 
FIORINI, Soeli T. ; LEITE, Julio Cesar Sampaio do Prado; LUCENA, José Carlos José Pereira de Lucena. Organizando Processos de Requisitos. Rio d Janeiro, 2010 (Artigo técnico. Escola Pontifícia Universidade Católica do Rio de Janeiro - PUC-Rio).

FORTUNE 100. Rankings. Disponível em <http://http://money.cnn.com/magazines/fortune/rankings/>. Acesso em: 10 junho 2010.

GANTOIS, Gustavo. Crédito alcança 40\% do PIB - Especial Perspectiva 2009 da Revista “Isto É Dinheiro”. Edição 587. São Paulo: Editora Três, 2008.

GARCIA, Felix Arthur. Governança Corporativa. Rio de Janeiro, Julho 2005. Monografia - Instituto de Economia, Universidade Federal do Rio de Janeiro.

GOLDMAN, Pedrinho. Introdução ao planejamento e controle de custos na construção civil brasileira. 4a edição. São Paulo: Editora Pini, 2004.

GLOBALTEC. Informações sobre o Sistema UAU. Disponível em: <http:// http://www.uau.com.br>. Acesso em: 30 maio 2010.

HALPIN, Daniel W. e RIGGS, Leland S. Planning and Analysis if Construction Operations. 1th edition. New York: John Wiley \& Sons, 1992.

HARTMAN, Francis; SKULMOSKI, Greg. Quest for Team Competence. Project Management Journal. Project Management Association Finland. Vol. 5, 1999.

HOWELL, Gregory A.; KOSKELA, Lauri. Reforming project management: the role of lean construction, in: 8th Annual Conference of the International Group for Lean Construction, July 2000, Brighton, UK.

IBGC - Instituto Brasileiro de Governança Corporativa. Conceito de Governança Corporativa. Disponível em < http://www.ibgc.org.br> Acesso em: 15 abril 2010.

IBGE - Instituto Brasileiro de Geografia Estatística. Taxa de investimento de 2010 foi a $2^{a}$ maior da década. [Reportagem de Alessandra Saraiva e Mônica 
Ciarelli]. Jornal 0 Estado de São Paulo, Economia \& Negócios, 3 de março,2011.

JDE - JD Edwards Enterprise one. Informações sobre o software. Disponível em: $\quad$ http://www.oracle.com/us/products/applications/jd-edwardsenterpriseone/index.html>. Acesso em: 15 abril 2010.

JESUS, Renata Gomes de. Implantação de Sistema ERP: Tecnologia e Pessoas no Projeto Garoto-SAP. Vitória, 2004. Dissertação (Mestrado) PRPPG - Pró-Reitoria de Pesquisa e Pós-Graduação - UFES.

JUNGLES, Antonio Edésio; SANTOS, Adriana de Paula Lacerda. Como gerenciar as compras de materiais na construção civil. $1^{\text {a }}$ Edição. São Paulo: Editora Pini, 2008.

KERZNER, Harold. Using the project management maturity model: strategic planning for project management. 2 th edition. New York, John Wiley \& Sons, 2005.

KERZNER, Harold. Gestão de Projetos - As melhores Práticas. 2a Edição, Porto Alegre: Bookman, 2004.

KRIECK, Manfredo. Ferramentas para uma Gestão eficaz. $1^{\text {a }}$ edição, Blumenau/SC, Learned Consultores Associados, 2003. Disponível em <http://www.learned.com.br>. Acesso em: 27 junho 2010.

KRUGMAN, Paul. A crise de 2008 e a economia da depressão. Revista de Economia Política, n. 30, janeiro, 2010. Disponível em <http://www.scielo.br/pdf/rep/v30n1/v30n1a12.pdf>. Acesso em: 15 maio 2011.

LACHMAN, Margie E. Planning and Crontrol Processes Acros the Life Span. International Journal of Behavioral Development. Lawrence Erlbaum Associates. London, 1993.

LAUFER, Alexander. Breaking de Code of Project Management. New York: Palgrave Macmillan, 2009. 
LAUFER, Alexander;TUCKER, Richard. Is construction Project planning really doing its job? A critical examination of focus, role and process. Construction Management and Economics, London, vol. 5, n.3, 1987.

LIMMER, Carl. Vicente. Planejamento, Orçamentação e Controle de Projetos e Obras. Rio de Janeiro: Livros Técnicos e Científicos Editora S/A, 1997.

LOTURCO, Bruno; Tecnologias da Informação. Revista Téchne, edição $n^{\circ}$ 91, p. 36 - 37, Outubro, 2004.

MCCABE, Steven. Benchmarking in construction. $1^{\text {th }}$ edition. London: Blackwell Science, 2001.

MARION, José Carlos. O Ensino da Contabilidade - Funções do Contador. 2005. Disponível em <http://www.marion.pro.br/portal>. Acesso em: 31 março 2010.

MATTOS, Aldo Dórea. Planejamento e Controle de Obras. $1^{\text {a }}$ edição. São Paulo: Editora Pini, 2010.

MATTOS, Aldo Dórea. Como preparar Orçamentos de Obras. $1^{a}$ edição. São Paulo: Editora Pini, 2006.

MEDEIROS, Eloisa; Plano Certeiro. Revista Construção São Paulo, edição $\mathrm{n}^{\circ}$ 85, Setembro, 2008.

MICHAELIS - Moderno Dicionário da Língua Portuguesa, $22^{\mathrm{a}}$ edição. São Paulo: Editora Melhoramentos, 2010.

MORAES, Rosa Maira de Mattos e SERRA, Sheyla Maria Baptista. Análise e estruturação do processo de planejamento da produção na construção civil. Revista INGEPRO - Inovação, Gestão e Produção, vol. 1, edição n 2 , Abril 2009.

NASA - National Aeronautics and Space Administration. Work Breakdown Structure Reference Guide, May 1994. 
NASCIMENTO, Luiz Antonio; LAURINDO, Fernando José Barbin; SANTOS, Eduardo Toledo. A eficácia da TI na Indústria da Construção Civil. In: SIBRAGEC - Simpósio Brasileiro de Gestão e Economia da Construção, São Carlos, 2003, p.1-8.

NETO, José Pires A. Gestão. [Entrevista a Kelly Carvalho]. Revista Construção Mercado, n. 54, p. 12- 14, janeiro, 2006.

NOCÊRA, Rosaldo de Jesus. Planejamento de Obras Industriais com MSProject. $1^{\mathrm{a}}$ edição. São Paulo: Ed. do Autor, 2006.

NOCÊRA, Rosaldo de Jesus. Planejamento de Obras Comerciais com MSProject. $1^{a}$ edição. São Paulo: Ed. do Autor, 2006.

NUNES, Paulo. Conceito de Organização. Disponível em: <http://www.knoow.net/cienceconempr/gestao/organizacao.htm> Acesso em: 10 Julho 2010.

O EMPREITEIRO. Ranking da Engenharia Brasileira - 500 Grandes da Construção - 2008. São Paulo: 0 empreiteiro. n. 37, jul. 2008. Edição Especial.

OH-CHEOL, Kwon; SANG-CHUL, Kim; JOON-HONG, Paek; SHIN-JO, Eom. Application of Earned Value in the Korean Construction Industry - A Case Study. Vol. 7 (2008), N 1 pp.69-76

OLIVEIRA, Paulo Vinícius Harada de. Implementação de um Processo de Programação de Obras em uma Pequena Empresa. Florianópolis, 2000. Dissertação (Mestrado) - Universidade Federal de Santa Catarina.

OLIVEIRA, Rodrigo César Franceschini de. Gerenciamento de projetos e a aplicação de análise de Valor Agregadol em grandes projetos. São Paulo, Outubro 2003. Dissertação (Mestrado) - Escola Politécnica, Universidade de São Paulo.

ORACLE. Informações sobre o Sistema E-Business Suite. Disponível em <http://www.oracle.com/br/index.htm>. Acesso em: 30 março 2010.

PADILHA, Thais Cássia Cabral. COSTA, Antônio Fernando Branco, CONTADOR, José Luiz e MARINS, Fernando Augusto Silva. Tempo de implantação de Sistemas ERP: Análise da Influência de fatores e aplicação 
de técnicas de Gerenciamento de Projetos. São Carlos, UFSCar, 2004 (Gestão \& Produção, publicado pela Universidade Federal de São Carlos) vol.11 no.1, Janeiro/Abril, 2004.

PMBOK. A guide to the project management body of knowledge. Atlanta: Project Management Institute, $3^{\mathrm{a}}$ edição, 2004. 388 p.

PMBOK. A guide to the project management body of knowledge. Atlanta: Project Management Institute, $4^{\mathrm{a}}$ edição, 2008. 337 p.

REHM, Mauro Velloso. Gestão on-line. [Entrevista a Kelly Carvalho]. Revista Construção Mercado, n. 20, p. 15-18, março, 2003.

RM Sistemas. Informações sobre o sistema RM. Disponível em: <http://www.rm.com.br>. Acesso em: 10 Julho 2010.

ROCHA, Ana Paula; Lei de Diretrizes Orçamentárias flexibiliza regras para licitações. Matéria divulgada na web em 08 de julho de 2010.

Disponível em: http://www.piniweb.com.br/construcao/legislacao/lei-dediretrizes-orcamentarias-flexibiliza-regras-para-licitacoes-178573-1.asp, Acesso em: 16 julho 2010.

RODRIGUES, Caio; LUBECK, Rafael Mendes; LADEIRA,Wagner Junior. 0 Processo de Implantação de Enterprise Resources Planning (ERP) e Custumer RelationShip Management (CRM): Influências e interferências. Anais do XXVIII Encontro Nacional de Engenharia de Produção, Rio de Janeiro, 2008.

SACCOL, Amarolinda Zanela; PEDRON, Cristiane Drebes; NETO, Guilherme Liberali; MACADAR, Marie Anne e CAZELLA, Silvio César. Avaliação do Impacto dos Sistemas ERP sobre Variáveis Estratégicas de Grandes Empresas no Brasil. Revista de Administração Contemporânea. Volume $n^{\circ} 8$, edição $n^{\circ} 1$, Curitiba, 2004.

SANTIN DE SOUZA, Maneula. Fluxo de caixa por regime de competência. São Paulo, 2006. Dissertação (Mestrado) - Faculdade de Economia, Administração e Contabilidade da Universidade de São Paulo.

SAP - Software de Gestão de Negócios. Informações sobre o Sistema Business Suite. Disponível em: 
<http://www.sap.com/brazil/solutions/business-suite>. Acesso em: 30 março 2010.

SILBER, Simão Davi. A economia mundial após a crise de 2007 e 2008. Revista USP, n. 85, maio, 2010.

SILVA, Alexsandro Amarante da. Programação de obras e curva de Gauss: uma medida de correlação. In: ENEGEP - Encontro Nacional de Engenharia de Produção, Porto Alegre, 1997.

SILVA, Mozart Bezerra da. Curso básico de orçamento de obras. Apostila do curso Básico de Orçamento de Obras. São Paulo: Editora Pini, Junho 1999.

SILVA, Mozart Bezerra da. Manual de BDI. $1^{\text {a }}$ Edição, São Paulo: Editora Pini, 2008.

SOUTO, Renata Gomes. Gestão do processo de planejamento da produção em empresas construtoras de edifícios: estudo de caso. São Paulo, Agosto 2006. Dissertação (Mestrado) - Escola Politécnica, Universidade de São Paulo.

SOUTO M. F., Marcos Antônio. Princípio e processo de padronização e a utilização de marca. Setembro de 2003. Disponível em: <http://jus2.uol.com.br/doutrina/texto.asp?id=5220> Acesso em: 21 abril 2010.

TACHIZAWA, Takeshy; MENDES, Gildásio. Como Fazer Monografia na Prática, 11 ${ }^{\mathrm{a}}$ edição, Rio de Janeiro: FGV Editora, 2006.

TCPO - Tabelas de Composições de Preços para Orçamentos, $13^{a}$ Edição, São Paulo: Editora Pini, 2008.

TISAKA, Maçahiko - Orçamento na Construção civil - consultoria, projeto e execução, $1^{a}$ Edição, São Paulo: Editora Pini, 2008.

TURBAN, Efraim; MC LEAN, Ephraim; WETHERBE, James. Tecnologia da Informação para Gestão. $3^{a}$ Edição. São Paulo: Bookman Companhia Ed., 2002, 660 p.

UPC - UNIVERSIDADE PERUANA DE CIÊNCIAS APLICADAS. Estadística aplicada a los negocios. Guía del alumno, Agosto 2010. 
VALENTE, Nelma Terezinha Zubek. Implementação de ERP em pequenas e médias empresas: estudo de caso em empresa do setor da construção civil. São Paulo, Dezembro 2004. Dissertação (Mestrado) - Faculdade de Economia, Administração e Contabilidade (FEA), Universidade de São Paulo.

ZEN, Thiago Henrique. Diretrizes para o uso de tecnologia da informação no Gerenciamento das Informações do processo de planejamento e controle da produção. Curitiba, 2006. Dissertação (Mestrado) - Universidade Federal do Paraná.

YIN, Robert K. Case Study Research - Design and Methods. $4^{\text {th }}$ edition. London: Sage Publications, 2009. 
ABDULLAH, S. Al-Mudimigh. The role and impact of business process management in enterprise systems implementation - Business Process Management Journal - volume 7, $n^{\circ}$ 6, 2007.

ABE, Marcel Takeshi. Trabalho sobre MS-Project. Apresentado à Escola Politécnica da Universidade de São Paulo na Disciplina de PEF 411 Engenharia de Software Aplicada à Engenharia de Estruturas, Junho 2000.

BARROS, Mércia Maria Bottura de. 0 setor de suprimentos no contexto da gestão da produção. São Paulo, 2001. Notas de aula - PCC-2302: Gestão da Produção na Construção Civil II/ Escola Politécnica da Universidade de São Paulo.

BERNARDES, Maurício Moreira e Silva; FORMOSO, Carlos Torres; REICHMANN, André Potrich. Modelos de planejamento de curto prazo para construção civil. In: ENEGEP - Encontro Nacional de Engenharia de Produção, Porto Alegre, 1997.

BRANÍCIO, Simone de Azevedo Ramos; PEIXOTO, Manoel Otelino da Cunha; CARPINETTI, Luiz Cesar Ribeiro. 0 monitoramento de informações tecnológicas externas para o desenvolvimento de novos produtos. In: ENEGEP - Encontro Nacional de Engenharia de Produção, Salvador, 2001, p.1-8.

BRASIL. Lei n. 8.666, de 21 de Junho de 1993. Dispõe sobre Normas Licitações e Contratos da Administração Pública. Diário Oficial da União, Poder Executivo, Brasília, DF, 22 jun.1993.

BUCHBINDER, Janet. Implementation Guide - Oracle Projects. Release 12, December 2006.

BUCHBINDER, Janet. Fundamentals - Oracle Projects. Release 12, December 2006.

${ }^{53}$ De acordo com a ABNT - Associação Brasileira de Normas Técnicas. NBR 6023 (2002). 
CHUA, David K. H. e GODINOT, Myriam. Use of a WBS Matrix to Improve Interface Management in Projects. Journal of construction engineering and management. Volume 132, Issue 1, pp. 67-79 (January 2006)

CLELAND, D. I. e IRELAND, L. R. Gerência de Projetos. Rio de Janeiro, Reichmann \& Affonso, 2002.

CLELAND, David I. e KING, Willian R. Project Management Handbook. Van Nostrand Reinhold, USA, 1983.

COLVARD, Jeffrey. Oracle Projects Costing - User Guide. Release 12, December 2006.

NCMA - National Contract Management Association. Contract Management Resource Guide 2010. Lancaster, PA, 2010. Disponível em <http://www.nxtbook.com/nxtbooks/ncma/contract_resourceguide10/\#/0>. Acesso em: 20 abril 2010.

DAVENPORT, Thomas $H$. Reengenharia de processos: como inovar na empresa através da tecnologia da informação. Rio de Janeiro: Editora Campus, 1994.

ELLET, Willian. Manual de Estudo de Caso - Como ler, discutir e escrever casos de forma persuasiva. $1^{\mathrm{a} e d i c ̧ a ̃ o . ~ S a ̃ o ~ P a u l o, ~ B o o k m a n ~ C o m p a n h i a ~ E d ., ~}$ 2008.

FIGUEIREDO, Francisco C. de, e FIGUEIREDO, Hélio. MS Project 98 utilização na Gerência de Projetos. $1^{\text {a }}$ edição. Rio de Janeiro: Editora Infobook, 1999.

GIDO, Jack; CLEMENTS, James P. Gestão de Projetos. Tradução da $3^{a}$ edição norte-americana, São Paulo, Thomson Learning, 2007.

GOMES, Josir Simeone. O Método de Estudo de Caso Aplicado À Gestão de Negócios - Textos e Casos. $1^{\text {a }}$ Edição. São Paulo: Editora Atlas, 2006.

GUERRA, Marco Aurélio d'Almeida. MITIDIERI, Cláudio Vicente. Sistema de Gestão Integrada em construtoras de edifícios. Como planejar e implantar um SGI. 1 ${ }^{a}$ edição. São Paulo: Editora Pini, 2010. 
KERZNER, Harold. Project Management: a systems approach to planning, scheduling and controlling. 19 th edition. New York, John Wiley \& Sons, 2006.

LAUFER, Alexander; TUCKER, R. L. Competence and timing dilemma in construcion planning. Construction Management and Economics, n. 6, p. 339-355, 1988.

LAUFER, Alexander; TUCKER, R. L. Is Construction Planning Really Doing its Job? A Critical Examination of Focus, Role and Process. Construction Management and Economics, v. 5, n. 3, p. 243-266, may 1987.

MANZIONE, Leonardo. Estudo de métodos de planejamento do processo de projeto de edifícios. São Paulo, Dezembro 2006. Dissertação (Mestrado) Escola Politécnica, Universidade de São Paulo.

MARQUES Junior, Luiz José. Uma contribuição para melhoria do planejamento de empreendimentos de construção em organizações públicas. São Paulo, Dezembro 2000. Dissertação (Mestrado) - Escola Politécnica, Universidade de São Paulo.

MATTA, Nadim F. e ASHKENAS, Ronald N. Gestão e Implementação de Projetos. $1^{a}$ edição. Rio de Janeiro: Editora Campus, 2005.

MENDES, Gustavo; Construção crescerá 8,8\% em 2010, diz SindusCon-SP. Disponível em: <http:// www.piniweb.com.br>. Acesso em: 10 Dezembro 2009.

MENEZES, LUÍS C. de M. Gestão de Projetos. $1^{\text {a }}$ edição. São Paulo: Editora Atlas, 2003.

MELHADO, Silvio Burrattino. Gestão, cooperação e integração para um novo modelo voltado a qualidade do processo na construção de edifícios. 2001. Tese (Livre-Docência) - Escola Politécnica, Universidade de São Paulo.

NASCIMENTO, Luiz Antonio do. Proposta de um sistema de recuperação de informação para extranet de projeto. São Paulo, Março 2004. Dissertação (Mestrado) - Escola Politécnica, Universidade de São Paulo. 
NASCIMENTO, Verônica de Menezes. Método Para Mapeamento do Fluxo de Informações de Processos Empresariais Um Estudo de Múltiplos Casos Aplicado ao Sistema de Comunicação em Empresas de Construção Civil São Paulo, Outubro 2006. Dissertação (Mestrado) - Escola de Engenharia de São Carlos (EESC)

NAVARRO, Silvana Sugano. Planejamento de Empreendimentos Imobiliários: Gestão de Risco Orientada à Gestão de Prazo com Ênfase na Identificação de Alertas Antecipados. São Paulo, 2007. Dissertação (Mestrado) - Escola Politécnica da Universidade de São Paulo.

OZAKI, Adalton e VIDAL, Antonio G. da R. In: SOUZA \& SACCOL. Sistemas ERP no Brasil (Enterprise Resource Planning): Teoria e Casos. São Paulo: Editora Atlas, 2003.

PATAH, Leandro Alves. Alinhamento estratégico de estrutura organizacional de projetos: uma análise de múltiplos casos. São Paulo, Maio 2004. Dissertação (Mestrado) - Escola Politécnica, Universidade de São Paulo.

PLUNKETT, Jack W. Plunkett's Almanac of Middle Market Companies 2008: Middle Market Research, Statistics \& Leading Companies. Plunkett Research, 2008.

RICARDINO, Roberto. Administração de contrato em projetos de construção pesada no Brasil: um estudo da interface com o processo de análise do risco. São Paulo, Julho 2007. Dissertação (Mestrado) - Escola Politécnica, Universidade de São Paulo.

ROCHA LIMA JR., João da; Sistemas de planejamento na construção civil gênese e informatização. São Paulo, EPUSP, 1990 (Boletim Técnico. Escola Politécnica da USP. Departamento de Engenharia de Construção Civil, BT/PCC-26/90, 74p.)

RODRIGUEZ, Mariuza; Planejamento de Obras - É assim que se faz - novos métodos e ferramentas de controle de obras ajudam as empresas a melhorar a performance. Revista Construção São Paulo, edição $n^{\circ} 12$, Julho, 2002.

SACOMANO, José Benedito; FUSCO, José Paulo Alves; GUERRINI, Fábio Müller; SANTOS, Myrian Tizuko Sassaki; MOCCELLIN, João Vitor. Administração de produção na construção civil o gerenciamento de obras 
baseado em critérios competitivos. São Paulo: Editora Arte \& Ciência, 2004.

SILVA, André Koide da. Método para avaliação e seleção de software de simulação de eventos discretos aplicados à análise de sistemas logísticos. São Paulo, 2004. Dissertação (Mestrado) - Escola Politécnica, Universidade de São Paulo.

SILVA, Sérgio Alfredo Rosa da Silva e GUELPA, Dante Francisco Victório. Métodos de Programação de Empreendimentos: Avaliação e Critérios para Seleção. São Paulo, EPUSP, 1993 (Boletim Técnico. Escola Politécnica da USP. Departamento de Engenharia de Construção Civil, BT/PCC-106/93, 22p.)

SILVA, Sérgio Alfredo Rosa da Silva. Programação por Recursos: 0 Desenvolvimento de um Método de Nivelamento e Alocação com Número Nebulosos para o Setor da Construção Civil. São Paulo, 1999. Tese (Doutoramento) - Escola Politécnica da Universidade de São Paulo

SILVA, Valtemir de Alencar e. Proposta de interface entre a WBS do projeto e a configuração do produto: uma contribuição para o acompanhamento de projetos. São Paulo, Outubro 2006. Dissertação (Mestrado) - Escola de Engenharia de São Carlos (EESC)

SOUZA, Cesar Alexandre de. Sistemas Integrados de Gestão Empresarial: Estudos de casos de implementação de Sistemas ERP. São Paulo, Maio 2000. Dissertação (Mestrado) - Faculdade de Economia, Administração e Contabilidade (FEA), Universidade de São Paulo.

STONNER, Rodolfo. Ferramentas de Planejamento: Utilizando o MS Project para gerenciar empreendimentos. $1^{\mathrm{a}}$ edição. Rio de Janeiro, E-papers Servicos Editoriais Ltda., 2005.

SUAREZ, Tathiana Massimino. Desenvolvimento de um modelo customizado de PDP para uma empresa mista de produtos e serviços. Porto Alegre, 2009. Dissertação (Mestrado) - Universidade Federal do Rio Grande do Sul.

VARGAS, Ricardo V. Manual Prático do Plano de Projeto: Utilizando o PMBOK Guide. $3^{a}$ edição. Rio de Janeiro, Brasport, 2007. 
WRITH, Almir. Planejando, replanejando e controlando com MS Project 2000. $2^{\text {a }}$ edição. Rio de Janeiro: Editora Book Express, 2002.

ZARLI, Alain. Ework and Ebusiness in Architecture, Engineering and Construction. $1^{\text {a }}$ edição. CRC Press, 2008. 
APÊNDICE A - Questionário para entrevista com os profissionais de gestão de contratos de obras - parte I

APÊNDICE B - Questionário para entrevista com os profissionais de gestão de contratos de obras - parte II

APÊNDICE C - Questionário para entrevista com os profissionais de empresas implantadoras de sistema de gestão de contratos de obras

APÊNDICE D - Roteiro para entrevista com profissionais das empresas participantes dos estudos de caso 


\section{APÊNDICE A - Questionário para entrevista com profissionais de gestão de contratos - parte I}

\begin{tabular}{|c|c|c|c|c|}
\hline Cargo & & \multirow{2}{*}{$\begin{array}{l}\text { Tempo de atuação na área de } \\
\text { gestão de contratos de obras }\end{array}$} & \multirow{2}{*}{$\begin{array}{l}\text { ( ) menos de } 1 \text { ano } \\
\text { ( ) entre } 1 \text { e } 5 \text { anos }\end{array}$} & \multirow{2}{*}{$\begin{array}{l}\text { ( ) entre } 5 \text { e } 10 \text { anos } \\
\text { ( ) mais de } 10 \text { anos }\end{array}$} \\
\hline Profissão & & & & \\
\hline $\begin{array}{c}\text { Área de atuação da } \\
\text { empresa }\end{array}$ & $\begin{array}{l}\text { ( ) Privada } \\
\text { ( ) Pública }\end{array}$ & $\begin{array}{l}\text { Número de colaboradores da } \\
\text { empresa em que atua }\end{array}$ & $\begin{array}{l}\text { ( ) de } 20 \text { a } 100 \\
\text { ( ) de } 101 \text { a } 500\end{array}$ & $\begin{array}{l}\text { ( ) de } 501 \text { a } 1000 \\
\text { ( ) mais de } 1000\end{array}$ \\
\hline
\end{tabular}

Tomando como base o processo de Gestão de Contratos de Obras, marque com "X" os elementos essencias que deveriam compor um Sistema Integrado para Gestão de Contratos de Obras de Construção Civil

1 - Essencial

2 - Importante, mas não essencial

3 - Irrelevante

Planejamento Físico

EAP - Estrutura Analítica do Projeto

\begin{tabular}{c|c|c|c|c}
1 & 2 & 3 & O Sistema deverá permitir a elaboração de EAP conforme necessidade do projeto
\end{tabular}

\begin{tabular}{l|l|l|l}
1 & 2 & 3 & O Sistema deverá permitir a padronização da EAP para todos os projetos
\end{tabular}

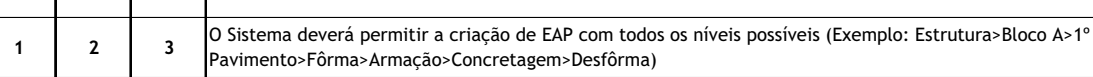

Cronograma

\begin{tabular}{l|l|l|l|l}
1 & 2 & 3 & O Sistema deverá permitir um comparativo entre baseline e versão atual
\end{tabular}

$\begin{array}{lllll}1 & 2 & 3 & \text { O Sistema deverá permitir a atualização baseada na integração com softwares específicos na elaboração de cronogramas como MS-Project }\end{array}$ \begin{tabular}{c|c|c|c|c|} 
& 2 & 3 & ou Primavera (atualização de datas, durações, predecessoras, gráfico de gantt) \\
\hline 1 & 2 & 3 & OSistema deva
\end{tabular}

\begin{tabular}{ll|l|l}
2 & 3 & O Sistema deverá armazenar todas as versões do cronograma mantendo um histórico de alterações
\end{tabular}

Controle Físico

Atualização do Avanço Físico

\begin{tabular}{l|l|l|l|l}
1 & 2 & 3 & O Sistema deverá permitir o avanço físico das tarefas através das quantidades executad
\end{tabular}

\begin{tabular}{c|c|c|l|l}
1 & 2 & 3 & O Sistema deverá permitir o avanço físico das tarefas através das horas executadas
\end{tabular}

Ponderação do Avanço Físico

\begin{tabular}{l|l|l|l|l}
1 & 2 & 3 & O Sistema deverá permitir a ponderação do avanço físico das tarefas pela Duração
\end{tabular}

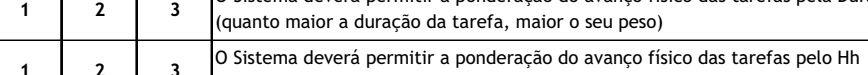

\begin{tabular}{l|l|l|l|l}
1 & 2 & 3 & $\begin{array}{l}\text { O Sistema devera permitir a ponderação do avanço } \\
\text { (quanto maior o Hh da tarefa, maior o seu peso) }\end{array}$ \\
\hline
\end{tabular}

\begin{tabular}{l|l|l|l}
1 & 2 & 3 & O Sistema deverá permitir a ponderação do avanço físico das tarefas pelo Custo
\end{tabular} (quanto maior o custo da tarefa, maior o seu peso)

Planejamento Financeiro - Orçamentos de Custo e Receit

$1 \quad 2 \quad 3 \quad$ O Sistema deverá permitir o acompanhamento do orçamento no nível dos Serviços (Exemplo: Lançamento de concreto bombeado fck 30

\begin{tabular}{ll|l|l|l|l}
1 & 2 & 3 & O Sistema deverá permitir o acompanhamento do orçamento no nível dos Insumos (Exemplo: Recursos necessários para Lançamento =
\end{tabular}

\begin{tabular}{l|l|l|l|l}
1 & 2 & 3 & $\begin{array}{l}\text { Sistena dereto, bomba, pedreiro, servente e etc) } \\
\text { concre }\end{array}$
\end{tabular}

\begin{tabular}{ll|l|l}
1 & 2 & 3 & O Sistema deverá permitir o acompanhamento do orçamento no nível da Verba (Exemplo: Verba para Fundações)
\end{tabular}

\begin{tabular}{|c|c|c|l|l|}
\hline \multicolumn{2}{|c|}{ Controle Financeiro } \\
\hline 1 & 2 & 3 & O Sistema deverá permitir o arquivamento das versões do Orcamento, mantendo histórico das versões \\
\cline { 1 - 3 } & 2 & 3 & O Sistema deverá permitir um comparativo entre baseline e versão atual \\
\hline 1 & 2 & 3 & O Sistema deverá permitir um comparativo entre versões \\
\hline 1 & 2 & 3 & O Sistema deverá possuir indicadores do projeto baseados no PMI \\
\hline 1 & 2 & 3 & O Sistema deverá permitir a criação de indicadores do projeto conforme necessidade da empresa \\
\hline
\end{tabular}


APÊNDICE B - Questionário para entrevista com profissionais de gestão de contratos - parte II

\begin{tabular}{|c|c|}
\hline \multicolumn{2}{|c|}{ Piorize abaixo os elementos essenciais para planejamento e controle, conforme a sua utilização e necessidade } \\
\hline 1 & Caminho crítico \\
\hline 2 & Curva S \\
\hline 3 & Diagrama de rede \\
\hline 4 & Durações \\
\hline 5 & EAP - Estrutura Analítica do Projeto \\
\hline 6 & Folgas \\
\hline 7 & Gráfico de gantt \\
\hline 8 & Linha de balanço \\
\hline 9 & Linha de base \\
\hline 10 & Precedências \\
\hline 11 & Recursos \\
\hline 12 & Valor agregado \\
\hline
\end{tabular}

Ferramentas que conhece para montagem de cronograma (Exemplo: MS-Project)

Sistema que conhece para Gestão de Contratos de Obras (Exemplo: SAP)

COMENTÁRIOS 


\section{APÊNDICE C - Questionário para entrevista com os profissionais de empresas implantadoras de sistema de gestão de contratos de obras}

\begin{tabular}{|c|c|c|c|}
\hline Cargo & \multirow{2}{*}{$\begin{array}{l}\text { Tempo de atuação na área de } \\
\text { implantação de sistema }\end{array}$} & ( ) menos de 1 ano & ( ) entre 5 e 10 anos \\
\hline Profissão & & ( ) entre 1 e 5 anos & ( ) mais de 10 anos \\
\hline
\end{tabular}

\begin{tabular}{|c|c|c|c|c|}
\hline $\begin{array}{c}\text { Tempo de atuação da empresa } \\
\text { na área de implantação de } \\
\text { sistemas }\end{array}$ & \begin{tabular}{|ll} 
( ) menos de 1 ano ( ) entre 5 e 10 anos \\
( ) entre 1 e 5 anos ( ) mais de 10 anos
\end{tabular} & $\begin{array}{c}\text { Número de colaboradores da } \\
\text { empresa em que atua }\end{array}$ & $\begin{array}{l}\text { ( ) de } 20 \text { a } 100 \\
\text { ( ) de } 101 \text { a } 500\end{array}$ & $\begin{array}{l}\text { ( ) de } 501 \text { a } 1000 \\
\text { ( ) mais de } 1000\end{array}$ \\
\hline \multicolumn{5}{|c|}{$\begin{array}{l}\text { Principais clientes } \\
\text { (construtoras) }\end{array}$} \\
\hline
\end{tabular}

\begin{tabular}{|l|l|l|}
\hline \multicolumn{2}{|c|}{ Na sua opinião, priorize as ferramentas de mercado mais implantada por construtoras } \\
\hline & 1 & EBS - E-business suite \\
\hline & 2 & JDE \\
\hline & 3 & SAP \\
\hline & 4 & UAU \\
\hline
\end{tabular}

\begin{tabular}{|c|c|}
\hline \multicolumn{2}{|c|}{ Sobre a implementação do Sistema Integrado para Gestão de Contratos de Obras, informe: } \\
\hline $\begin{array}{c}\text { Tempo médio de Implementação do Sistema } \\
\text { (módulo de Gestão de projetos) }\end{array}$ & \\
\hline $\begin{array}{c}\text { Quantidade média de profissionais envolvidos pela } \\
\text { empresa implantadora }\end{array}$ & \\
\hline $\begin{array}{c}\text { Quantidade média de profissionais envolvidos pela } \\
\text { empresa construtora }\end{array}$ & \\
\hline
\end{tabular}

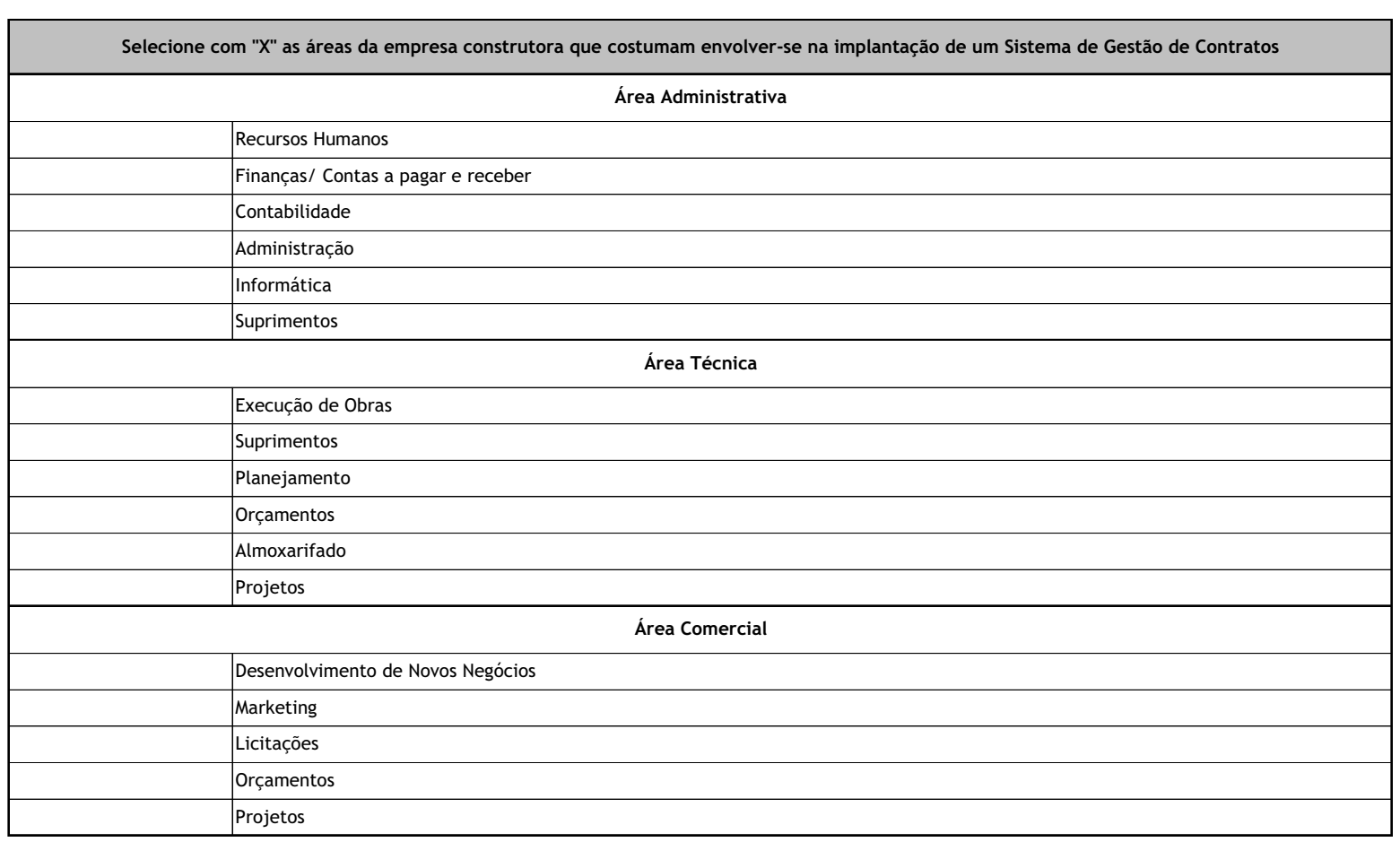


APÊNDICE D - Roteiro para entrevista com profissionais das empresas participantes dos estudos de caso

\begin{tabular}{|l}
\hline Caracterização da empresa \\
\hline Tempo de atuação da empresa no mercado \\
\hline Área de atuação \\
\hline Principais clientes \\
\hline Características das Obras \\
\hline Número de obras com o Sistema de Gestão implementado \\
\hline Número de colaboradores
\end{tabular}

Implementação do Sistema Integrado para Gestão de Contratos de Obras

Estratégia de atuação adotada

Tempo de Implementação (cronograma)

Funções e Responsabilidades dos envolvidos

Análise do Fluxograma de implantação 
Elaboração/organização dos dados a serem implementados no Sistema

Responsável pela definição da EAP - Estrutura Analítica de Projetos

(Qual área da Empresa? Escritório, Cliente ou Obra?)

Responsável pelo detalhamento da EAP - Estrutura Analítica de Projetos no MS-Project ou Primavera

(Quem define o detalhamento da EAP para acompanhamento do projeto? Escritório? Cliente ou Obra?

Nível de detalhamento da EAP - Estrutura Analítica de Projetos no EBS - E-business suite

(Após definir a EAP e seu respectivo detalhamento, quem define o nível de detalhamento a ser controlado no EBS?)

Responsável pela elaboração do orçamento de Custo e Receita

(Qual área da empresa é responsável pela elaboração dos orçamentos que vão para o EBS?)

Responsável pela carga dos dados iniciais (baseline) na Ferramenta.

Por exemplo:

- Cronograma

- Orçamento de Custo

- Orçamento de Receita

(Quem faz a carga no EBS dos dados exemplificados?)

\section{CRONOGRAMA}

Responsáveis pela atualização do cronograma

(Quem faz a atualização do cronograma da Obra?)

Como é atualizado o cronograma?

(Ocorre no Ms-Project ou diretamente no EBS?)

Qual é a ponderação de avanço físico do projeto utilizada?

A ponderação é feita no MS-Project ou no EBS?

O Avanço físico informado no EBS utiliza qual ponderação? 


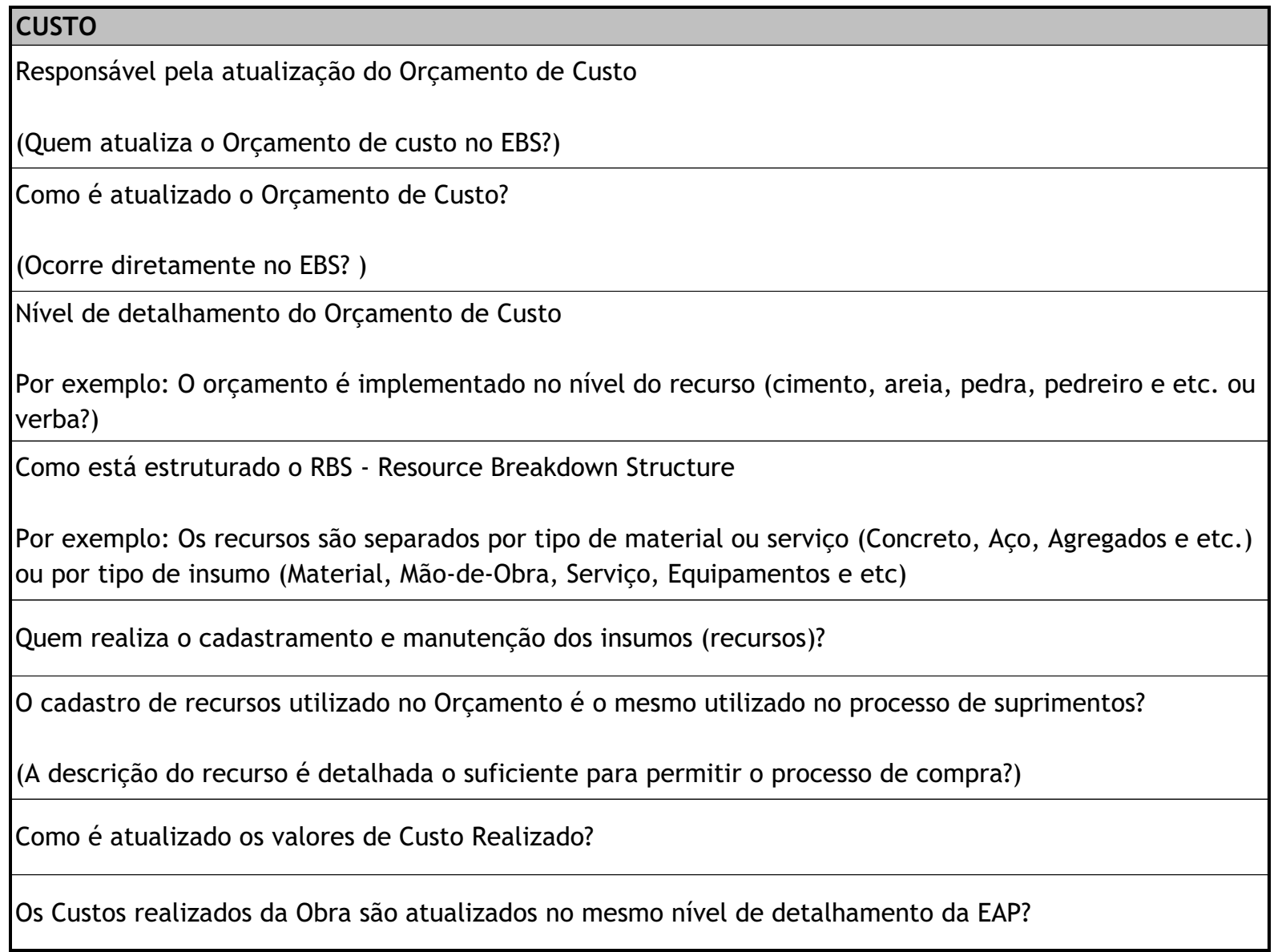

\begin{tabular}{|l|}
\hline RECEITA \\
\hline Quem faz a atualização do Orçamento de Venda no EBS? \\
\hline Como é atualizado o Orçamento de Venda? \\
(Ocorre diretamente no EBS? ) \\
\hline Como é atualizado os valores de Receita realizada? \\
\hline
\end{tabular}


Controle Físico e Financeiro

Quem monitora a atualização dos dados na ferramenta?

Como é o relacionamento estre a Estrutura Física (EAP) e Financeira (EFP) ou seja (WBS x FBS)

A empresa utiliza a Análise do Valor Agregado nos projetos implementados na ferramenta?

Quais são os indicadores de desempenho utilizados?

\section{Treinamentos}

Estratégia adotada para ministrar os treinamentos da equipe (Por exemplo, ministrar na obra ou em hotel para tirar da obra)

Treinamentos realizados para nivelar conhecimentos dos profissionais envolvidos (Por exemplo: Gestão de Projetos, MS-Project, Primavera e etc.)

Grade dos treinamentos, Carga Horária, Palestrante

Quantidade de profissionais treinados por treinamento

Quantidade de profissionais treinados por treinamento

\section{Utilização da Ferramenta}

A ferramenta foi implantada na sua plenitude

Processos principais implantados 
Apoio na atualização dos dados

Há Equipe de apoio para suporte na utilização do Sistema Integrado de Gestão (EBS)?

Perfil dos colaboradores que apoiam a ferramenta (cargo e formação)

\section{Dificuldades enfrentadas}

Principais dificuldades enfrentadas na fase de implantação na sede

Principais dificuldades enfrentadas na fase de implantação na obra

Há processos ou decisões da implantação que poderiam ter sido de outra forma 